Kemény Ildikó:

\title{
A VERSENYTÁRSAK CSAK EGY KATTINTÁSRA VANNAK Az újravásárlási és továbbajánlási szándék alakulása különböző e- kereskedelmi kategóriákban
}


Marketingkutatás és Fogyasztói Magatartás Tanszék

Doktori tézis

Kemény Ildikó:

\section{A VERSENYTÁRSAK CSAK EGY KATTINTÁSRA VANNAK \\ Az újravásárlási és továbbajánlási szándék alakulása különböző e- kereskedelmi kategóriákban}

Témavezető: dr. Simon Judit, CSc

egyetemi tanár

(C) Kemény Ildikó

Budapest, 2015. 
Budapesti Corvinus Egyetem

Gazdálkodástani Doktori Iskola

\section{A VERSENYTÁRSAK CSAK EGY KATTINTÁSRA VANNAK Az újravásárlási és továbbajánlási szándék alakulása különböző e- kereskedelmi kategóriákban \\ Kemény Ildikó}

Budapest, 2015. 


\section{Tartalomjegyzék}

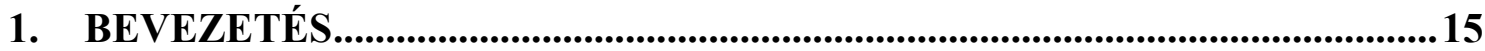

1.1. A kutatás célja .................................................................................................................. 18

1.2. A kutatás elméleti és gyakorlati vonatkozása.........................................................19

1.3. A dolgozat felépítése ...............................................................................................19

2. SZAKIRODALMI ÁTTEKINTÉS ....................................................................21

2.1. A minőség szerepe a vállalati működésben....................................................222

2.2. A hagyományos szolgáltatásminőség megközelítéstől az elektronikus

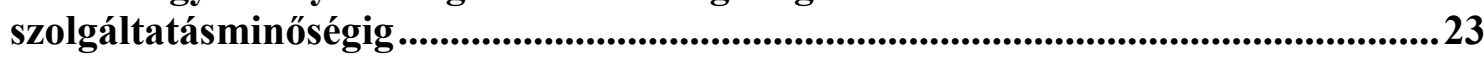

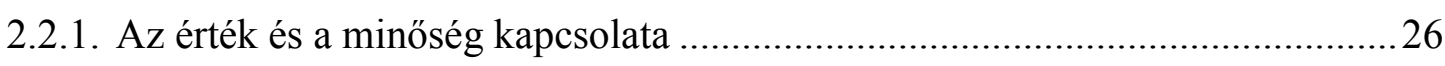

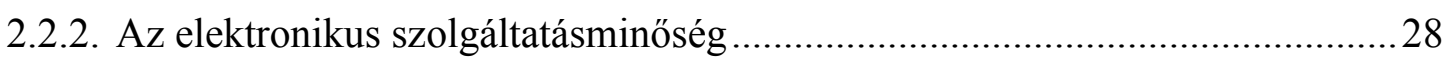

2.3. Az elektronikus kereskedelem ..................................................................31

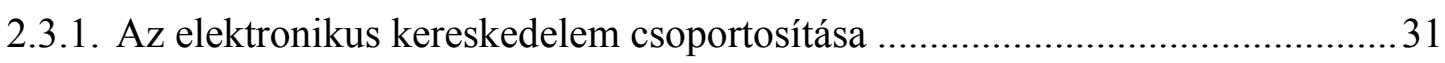

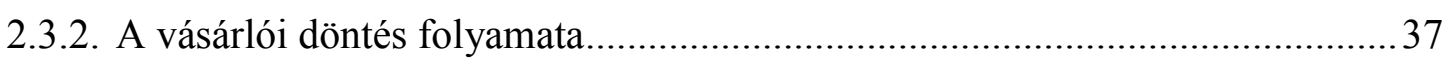

2.3.3. A vásárlási folyamat az elektronikus kereskedelem esetében .......................... 38

2.4. Az elektronikus szolgáltatásminőség mérésére szolgáló skálák........................40

2.4.1. A legelső próbálkozások az elektronikus szolgáltatásminőség területén ..........41

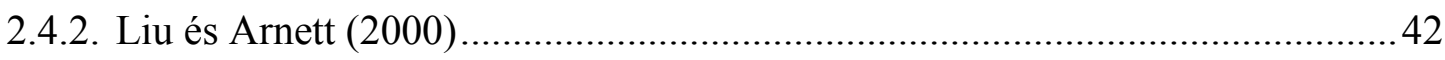

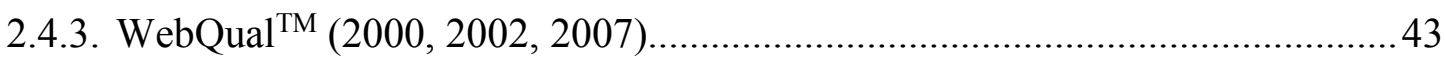

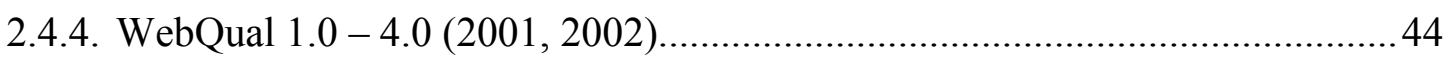

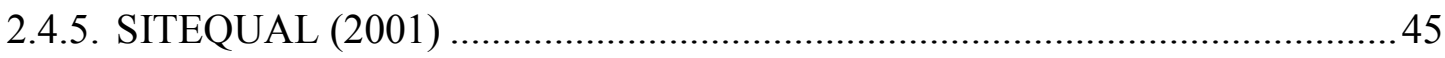

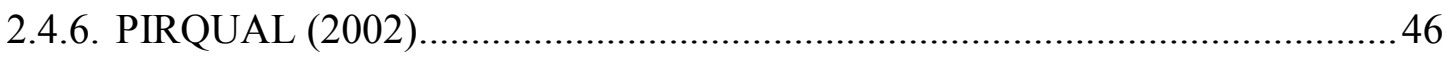

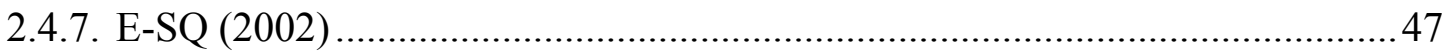

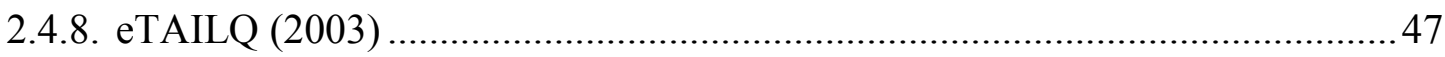

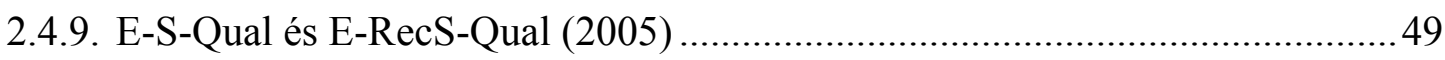

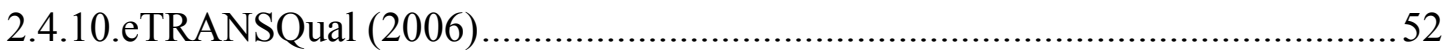

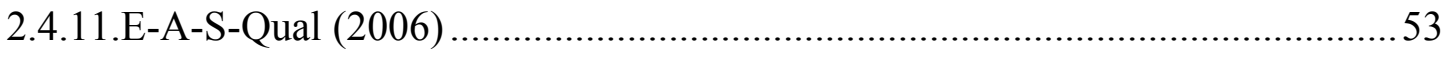

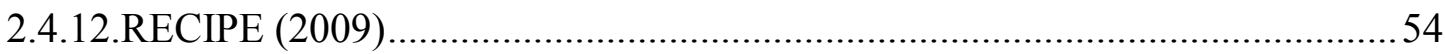

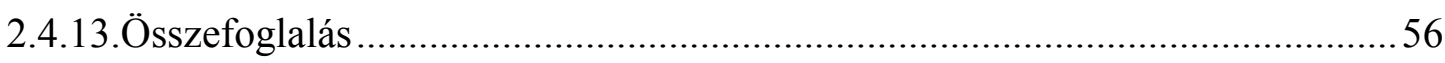

2.5. A fogyasztói elégedettség ..............................................................................6 64

2.5.1. Az elektronikus szolgáltatásminőség és az elégedettség kapcsolata .................64

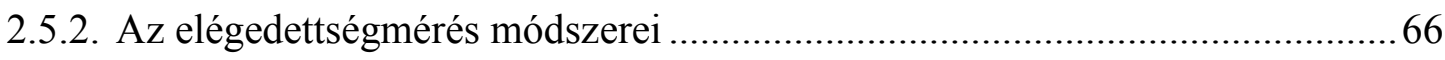

2.5.3. Az elégedettség mérése a diszkonfirmációs paradigmával.............................6 68

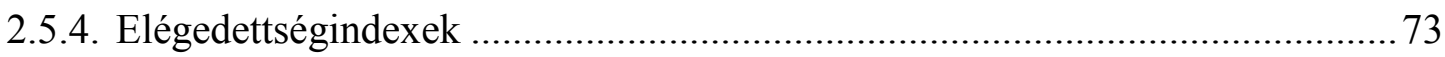

2.6. Az elégedettség következményei ............................................................75 


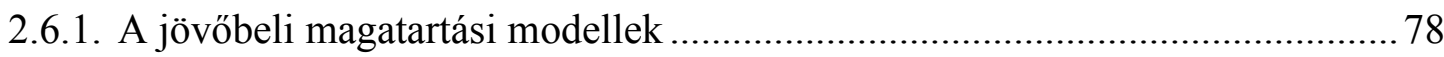

2.6.2. Az újravásárlási szándék és a szájreklám kapcsolata az elégedettséggel .........80 80

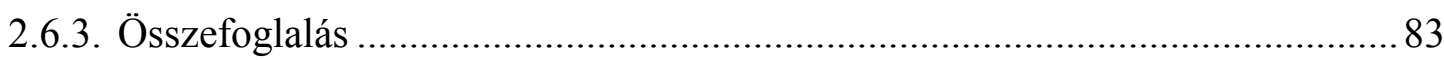

3. AZ EMPIRIKUS KUTATÁS ......................................................................8 84

3.1. A kutatás elméleti kerete .....................................................................................84

3.2. Kutatási kérdések és hipotézisek ................................................................ 85

3.3. Az elméleti fogalmak operacionalizálása ....................................................90

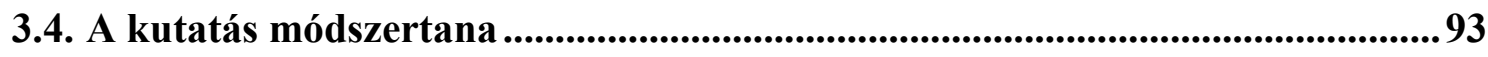

3.5. Elemzési módszertan: variancia és/vagy kovariancia alapú modellezés ..........94

4. A MEGVALÓSÍTOTT KUTATÁSOK ÉRTÉKELÉSE ..................................100

4.1. A nagymintás online, kérốíves kutatása ....................................................100

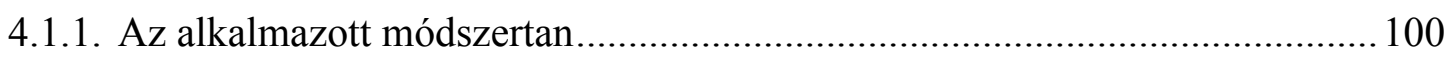

4.1.2. Az e-kereskedelemi csoportok közti eltérések............................................ 103

4.1.3. Az elektronikus szolgáltatásminőség értékelése ........................................... 105

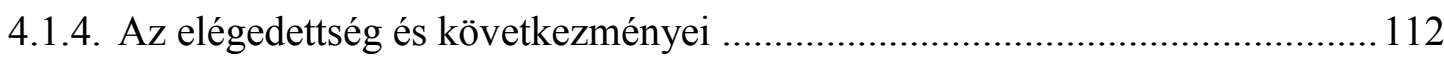

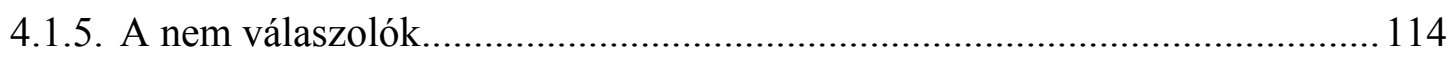

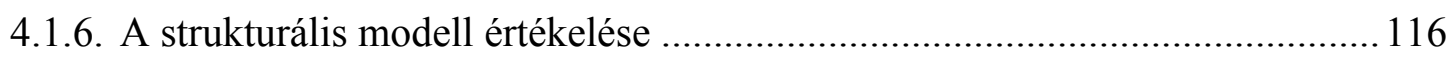

4.1.7. A mérési modell, vagyis az elmélet tesztelése............................................... 118

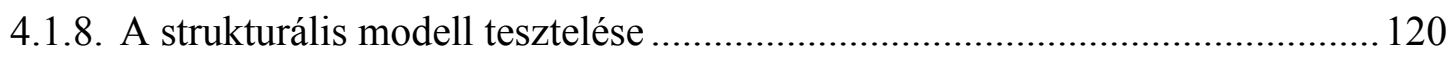

4.1.9. A teljes tapasztalattal rendelkezők modellje............................................... 120

4.1.10 .............A biztonsággal kapcsolatban hiányos tapasztalattal rendelkező vásárlók

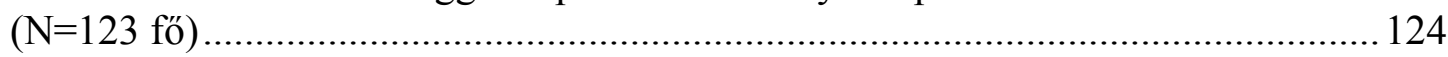

4.1.11...Az ügyfélszolgálattal kapcsolatban hiányos tapasztalattal rendelkező vásárlók

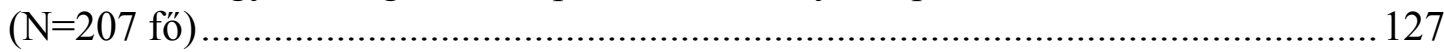

4.1.12.A biztonsággal és az ügyfélszolgálattal kapcsolatban hiányos tapasztalattal

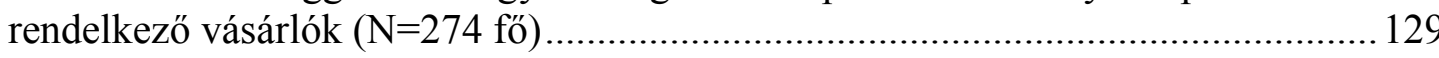

4.2. A szegmensek közötti különbségek értékelése többcsoportos elemzéssel (MGA) ............................................................................................................... 131

4.2.1. A teljes tapasztalattal rendeletezők értékelése (MGA) ................................. 131

4.2.2. A biztonsággal kapcsolatban hiányos tapasztalattal rendelkező vásárlók (MGA) 134

4.2.3. Az ügyfélszolgálattal kapcsolatban hiányos tapasztalattal rendelkező vásárlók (MGA)

4.2.4. A biztonsággal és az ügyfélszolgálattal kapcsolatban hiányos tapasztalattal

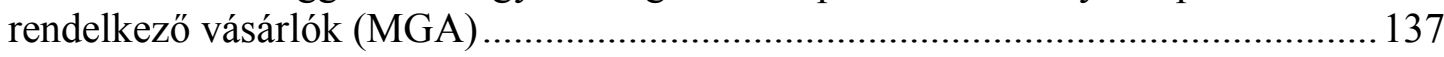

4.3. A nagymintás, online kérdő́ves kutatás összefoglalása ................................. 138

4.4. Az elégedettség alakulása offline- és elektronikus-termék vásárlása esetében: Kísérleti kutatás ........................................................................................................142

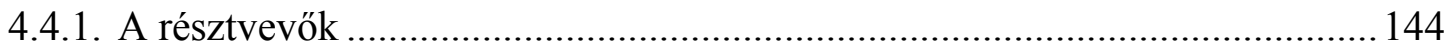


4.4.2. A megvalósult vásárlások értékelése .......................................................... 147

4.4.3. A vásárláshoz kapcsolódó vélemények értékelése ..................................... 149

4.4.4. Az első és az újravásárlók összehasonlítása ................................................. 154

5. AZ EREDMÉNYEK INTERPRETÁCIÓJA, KÖVETKEZTETÉSEK ........156

5.1. Föbb következtetések ................................................................................... 157

5.2. A hipotézisvizsgálat eredményei .................................................................158

5.3. Elméleti és gyakorlati relevanciák................................................................165

5.4. A kutatás korlátai és a jövőbeni kutatási irányok ........................................167

HIVATKOZOTT IRODALOM ..................................................................169

1. Melléklet: A legfontosabb mutatók az interneteléréssel, internethasználattal, illetve

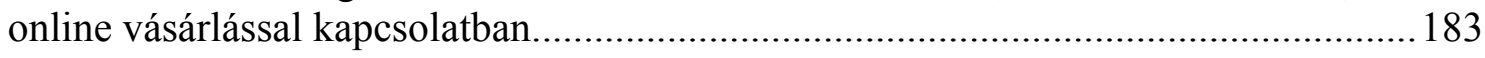

2. Melléklet: Az EU27 országokban online vásárolt termékek és szolgáltatások köre

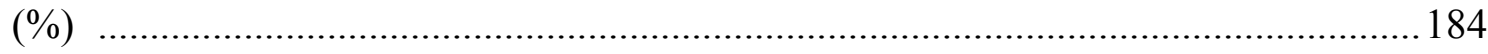

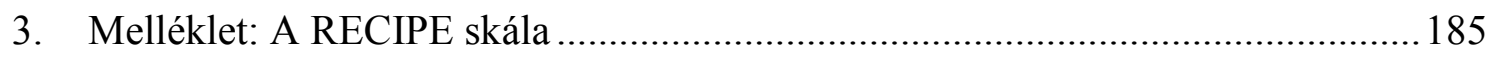

4. Melléklet: A tényleges mérési tételek és a hozzájuk tartozó kódok ....................... 187

5. Melléklet: A felhasznált skálák hasonlósági érvényessége ................................. 189

6. Melléklet: A látensekhez tartozó indikátorok súlyai (loadingok) - teljes tapasztalattal rendelkezők

7. Melléklet: PLS útelezmés eredményei, amennyiben a hiányzó értékeket átlaggal

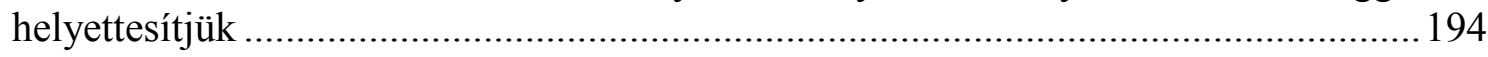

8. Melléklet: Indirekt utak (teljes tapasztalattal rendelkezők) ................................. 196

9. Melléklet: A csak egy kattintás.hu web-shop - életképek ..................................... 197

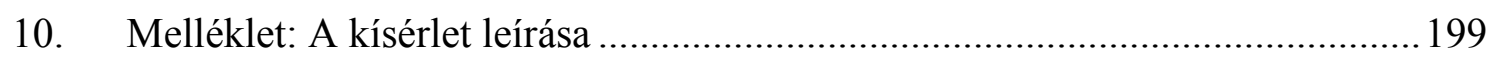

11. Melléklet: A kapcsolódó előtanulmányok eredményei ...................................201

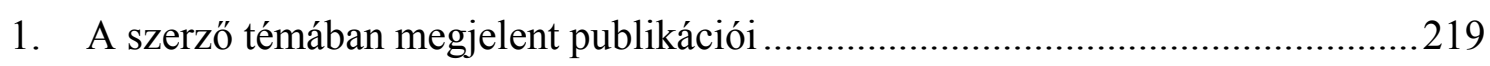




\section{ÁBRAJEGYZÉK}

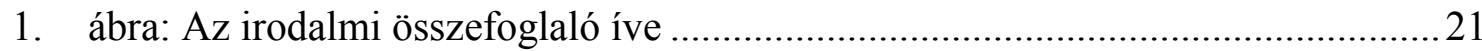

2. ábra: Az elvárt és tapasztalt minőséget befolyásoló tényezők.................................22

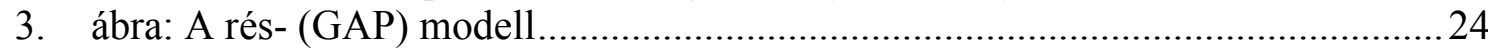

4. ábra: A résmodell alakulása az elektronikus kereskedelem esetében......................26

5. ábra: A teljes fogyasztói élmény kialakulása online környezetben .........................29

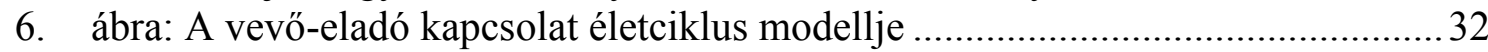

7. ábra: Az e-kereskedelmi kategóriái a teljesítés módja és a termék jellege szerint.. 35

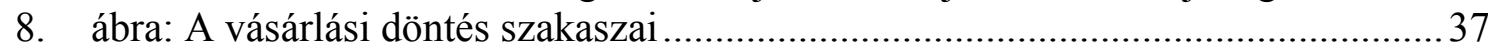

9. ábra: Vevőorientált mérési módszerek az elégedettség esetében ............................66

10. ábra: A pozitív, a negatív és a zéró diszkonfirmáció kialakulása és

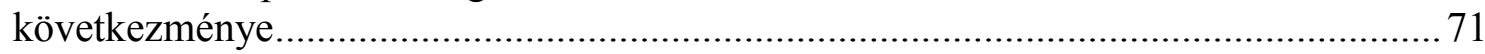

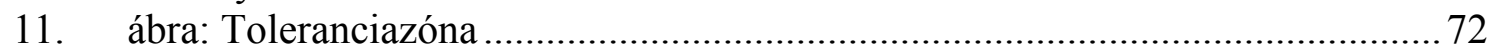

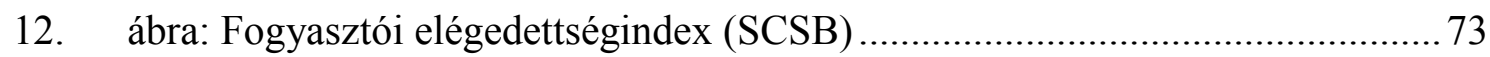

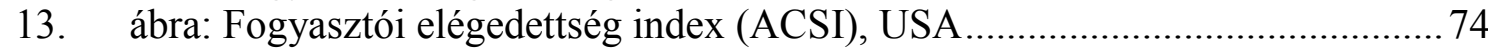

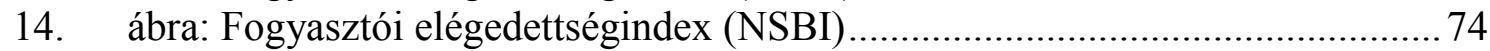

15. ábra: A szolgáltatásminőség és a szájreklám kapcsolata .................................76

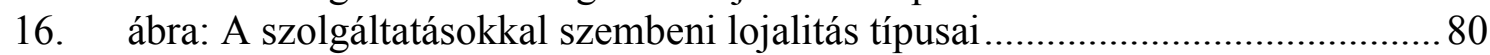

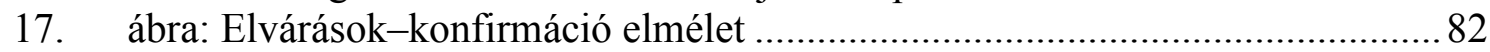

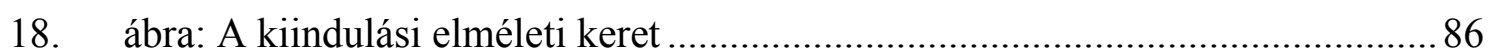

19. ábra: A SEM módszertan használatának folyamatábrája..................................... 98

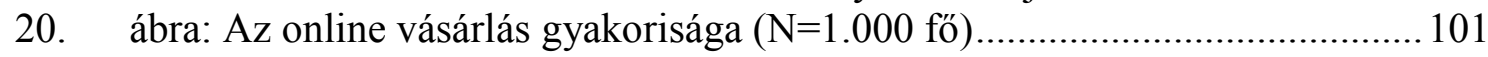




\section{TÁBLÁZATOK}

1. táblázat: A hagyományos és az online szolgáltatásminőség összehasonlítása ........25

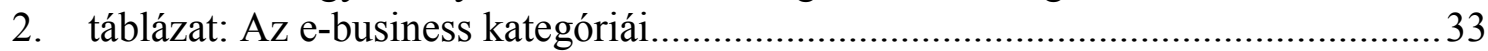

3. táblázat: A Magyarországon online vásárolt termékek és szolgáltatások köre, több

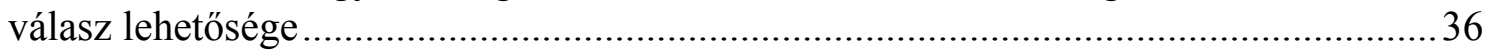

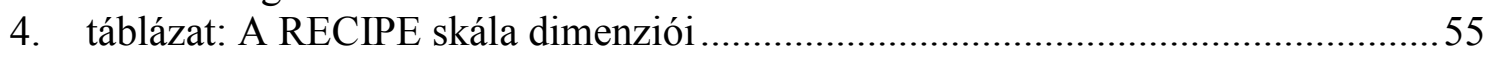

5. táblázat: A megvizsgált elektronikus szolgáltatásminőség skálák értékelése az e-

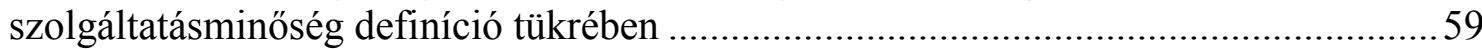

6. táblázat: A megvizsgált elektronikus szolgáltatásminőség skálák összefoglalója...63

7. táblázat: A tervezett kutatási módszertan .............................................................. 94

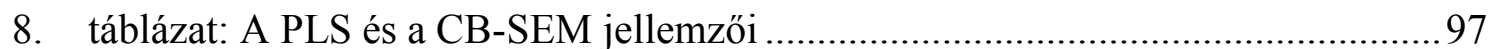

9. táblázat: A nagymintás kutatási minta demográfiai jellemző................................. 100

10. táblázat: A kutatás középpontjában álló online vásárlás leíró jellemzői $(\mathrm{N}=1.000$

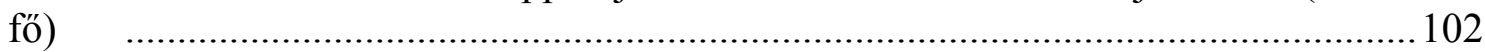

11. táblázat: A kutatás középpontjában álló online vásárlás leíró jellemzői (N=500-

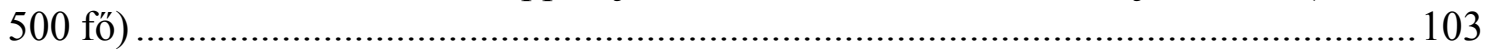

12. táblázat: Az elemzett e-kereskedelmi csoportok vásárlóinak demográfiai

jellemzői (N=366/134/273/263/1000 fó) …............................................................ 104

13. táblázat: Az elemzett e-kereskedelmi csoportok vásárlóinak leíró jellemző

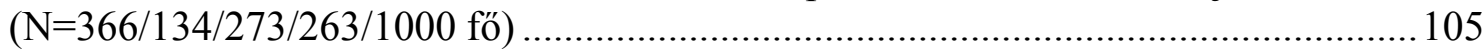

14. táblázat: Konkrét webshopminőség értékelése (1-7 skála) (N=366/134/273/263

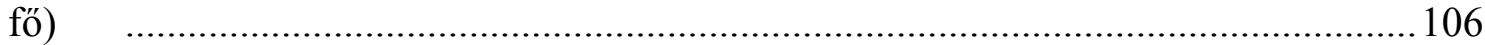

15. táblázat: Konkrét webshopminőség értékelése közti különbségek az e-

kereskedelmi kategóriák esetében (1-7 skála) ( $N=366 / 134 / 273 / 263$ fó) ....................... 107

16. táblázat: A vásárlás lebonyolításának értékelése (1-7 skála) $(\mathrm{N}=366 / 134 / 273 / 263$

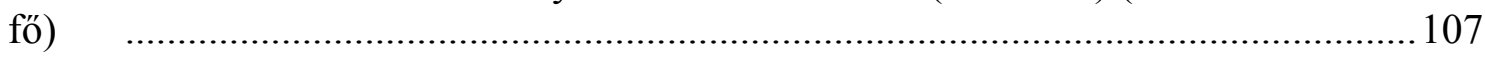

17. táblázat: A vásárlás lebonyolításának értékelése közti különbségek az e-

kereskedelmi kategóriák esetében (1-7 skála) (N=366/134/273/263fó) ..................... 108

18. táblázat: Az észlelt biztonság értékelése (1-7 skála) ...................................... 109

19. táblázat: Az észlelt bizonság értékelése közti különbségek az e-kereskedelmi

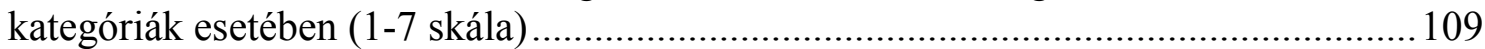

20. táblázat: Az ügyfélszolgálat értékelése (1-7 skála) ...................................... 110

21. táblázat: Az ügyfélszolgálat értékelése közti különbségek az e-kereskedelmi

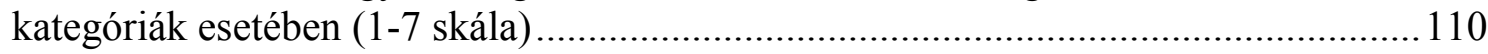

22. táblázat: Az szummázott minőségészlelés értékelése (1-7 skála) ..................... 111

23. táblázat: A szummázott minőségészlelés közti különbségek az e-kereskedelmi

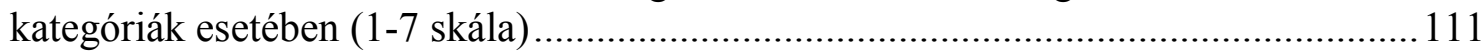

24. táblázat: Az elégedettség, hagyományos és e-továbbajánlási hajlandóság,

valamint az újravásárlási szándék értékelése (1-7 skála) ......................................... 112

25. táblázat: A vizsgált e-kereskedelmi kategóriák közti különbség az elégedettség, hagyományos és e-továbbajánlási hajlandóság, valamint az újravásárlási szándék

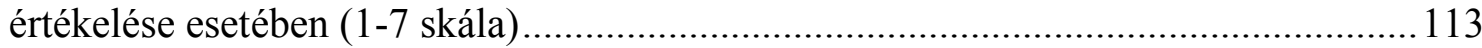

26. táblázat: A nem válaszolók megoszlása a mintában ........................................ 114

27. táblázat: A nem válaszolók megoszlása a mintában a konkrét kérdések/változók esetében

28. táblázat: A nem válaszolók megoszlása a mintában a vizsgált e-kereskedelmi

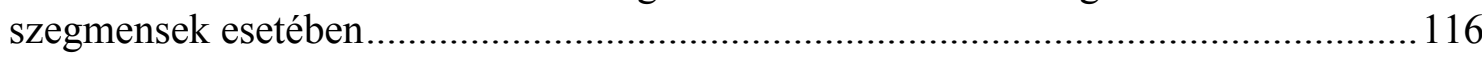

29. táblázat: A nem válaszolók csoportjai és a hiánytalan kitöltők közti különbségek

a vásárlás értékeléséhez köthető dimenziók esetében ............................................... 117

30. táblázat: A mérési modell tesztelésének eredménye (belső megbízhatóság, hasonlósági érvényesség) 
31. táblázat: Az elektronikus-szolgáltatásminőség dimenzióinak hatása az elégedettségre: az útegyütthatók értéke és relevanciája a teljes tapasztalattal rendelkezők

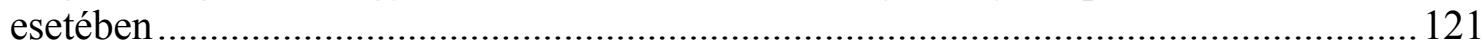

32. táblázat: A változók közötti hatások jelentősége ( $a z \mathrm{f}^{2}$ mutató értéke) .............. 123

33. táblázat: A függő változók magyarázott varianciája (R2) .............................. 123

34. táblázat: Az elégedettség hatása a hagyományos és e-továbbajánlási szándékra valamitn az újravásárlási hajlandóságra: az útegyütthatók értéke és relevanciája a teljes tapasztalattal rendelkezők esetében .... 124

35. táblázat: Az elektronikus-szolgáltatásminőség dimenzióinak hatása az elégedettségre: az útegyütthatók értéke és relevanciája a biztonsággal kapcsolatban hiányos tapasztalattal rendelkező vásárlók

36. táblázat: A változók közötti hatások jelentősége (az f mutató értéke) biztonsággal kapcsolatban hiányos tapasztalattal rendelkezők

37. táblázat: A függő változók magyarázott varianciája $\left(\mathrm{R}^{2}\right)$ - biztonsággal kapcsolatban hiányos tapasztalattal rendelkezők

38. táblázat: Az elégedettség hatása a hagyományos és e-továbbajánlási szándékra valamint az újravásárlási hajlandóságra: az útegyütthatók értéke és relevanciája a biztonsággal kapcsolatban hiányos tapasztalattal rendelkezők esetében

39. táblázat: Az elektronikus-szolgáltatásminőség dimenzióinak hatása az elégedettségre: az útegyütthatók értéke és relevanciája az ügyfélszolgálattal kapcsolatban hiányos tapasztalattal rendelkező vásárlók

40. táblázat: A változók közötti hatások jelentősége ( $a z \mathrm{f}^{2}$ mutató értéke) - az ügyfélszolgálattal kapcsolatban hiányos tapasztalattal rendelkezők

41. táblázat: A függő változók magyarázott varianciája $\left(\mathrm{R}^{2}\right)$ - az ügyfélszolgálattal kapcsolatban hiányos tapasztalattal rendelkezők

42. táblázat: Az elégedettség hatása a hagyományos és e-továbbajánlási szándékra valamint az újravásárlási hajlandóságra: az útegyütthatók értéke és relevanciája az ügyfélszolgálattal kapcsolatban hiányos tapasztalattal rendelkezők esetében.

43. táblázat: Az elektronikus-szolgáltatásminőség dimenzióinak hatása az elégedettségre: az útegyütthatók értéke és relevanciája a biztonsággal és ügyfélszolgálattal kapcsolatban hiányos tapasztalattal rendelkező vásárlók

44. táblázat: A változók közötti hatások jelentősége (az f $\mathrm{f}^{2}$ mutató értéke) - a biztonsággal és ügyfélszolgálattal kapcsolatban hiányos tapasztalattal rendelkezők ... 130 45. táblázat: A függő változók magyarázott varianciája $\left(\mathrm{R}^{2}\right)$ - az biztonsággal és ügyfélszolgálattal kapcsolatban hiányos tapasztalattal rendelkezők

46. táblázat: Az elégedettség hatása a hagyományos és e-továbbajánlási szándékra valamint az újravásárlási hajlandóságra: az útegyütthatók értéke és relevanciája a biztonsággal és ügyfélszolgálattal kapcsolatban hiányos tapasztalattal rendelkezők esetében.....

47. táblázat: Az e-kereskedelmi szegmensek közötti páronkénti különbségek - teljes tapasztalattal rendelkezők

48. táblázat: A függő változók magyarázott varianciája $\left(\mathrm{R}^{2}\right)$ közti különbségek a szegmensek között - teljes tapasztalattal rendelkezők

49. táblázat: Az e-kereskedelmi szegmensek közötti páronkénti különbségek biztonsággal kapcsolatban hiányos tapasztalattal rendelkezők

50. táblázat: A függő változók magyarázott varianciája $\left(\mathrm{R}^{2}\right)$ közti különbségek a szegmensek között - biztonsággal kapcsolatban hiányos tapasztalattal rendelkezők .. 135 51. táblázat: Az e-kereskedelmi szegmensek közötti páronkénti különbségek - az ügyfélszolgálattal kapcsolatban hiányos tapasztalattal rendelkezők 135 52. táblázat: A függő változók magyarázott varianciája $\left(\mathrm{R}^{2}\right)$ közti különbségek a szegmensek között - ügyfélszolgálattal kapcsolatban hiányos tapasztalattal rendelkezők 
53. táblázat: A függő változók magyarázott varianciája $\left(\mathrm{R}^{2}\right)$ közti különbségek a szegmensek között - biztonsággal és ügyfélszolgálattal kapcsolatban hiányos tapasztalattal rendelkezők

54. táblázat: A függő változók magyarázott varianciája $\left(\mathrm{R}^{2}\right)$ közti különbségek a szegmensek között - biztonsággal és ügyfélszolgálattal kapcsolatban hiányos tapasztalattal rendelkezők

55. táblázat: Az e-szolgáltatásminőség dimenziók hatása az elégedettségre a különböző e-kereskedelmi kategóriák esetében - Összefoglalás

56. táblázat: Az elégedettség hatása a hagyományos és e-továbbajánlási szándékra valamint az újravásárlási hajlandóságra a különböző e-kereskedelmi kategóriák esetében - Összefoglalás 141

57. táblázat: A kísérletben résztvevők demográfiai jellemzői $(\mathrm{N}=100$ fö) ................ 144

58. táblázat: A kísérletben résztvevők e-vásárlási szokásai $(\mathrm{N}=100$ fö).................... 145

59. táblázat: A kísérletben résztvevők e-vásárlási szokásai: az elmúlt három hónapban online vásárolt termékek és szolgáltatások listája $(\mathrm{N}=100$ fó) .................... 145

60. táblázat: A megvalósított vásárlások értékelése $(\mathrm{N}=100$ fö) .............................. 146

61. táblázat: Az első és újravásárlások átlagai közti különbségek $(\mathrm{N}=100$ fö) ......... 147

62. táblázat: Az első és az újravásárlások átlagai közötti különbségek értékelése a két

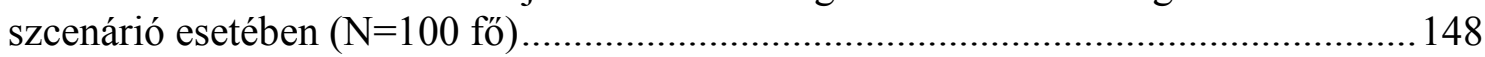

63. táblázat: Az offline-termék vásárlásához köthető véleményekben megjelent pozitív értékek ( $\mathrm{N}=100$ komment).

64. táblázat: Az offline-termék vásárlásához köthető véleményekben megjelent negatív értékek ( $\mathrm{N}=100$ komment)

65. táblázat: Az e-termék vásárlásához köthető véleményekben megjelent pozitív értékek ( $\mathrm{N}=100$ komment).

66. táblázat: Az e-termék vásárláshoz köthető véleményekben megjelent negatív értékek ( $\mathrm{N}=100$ komment)

67. táblázat: A vásárláshoz köthető kommentek csoportosítása ( $\mathrm{N}=100$ komment $) 152$

68. táblázat: A kommentekben megjelenő negatív és pozitív említések számának $(\mathrm{db})$ kapcsolata a véleményekhez és a vásárláshoz köthető metrikus adatokkal - Offlinetermék vásárlása $(\mathrm{N}=100$ komment $)$....

69. táblázat: A kommentekben megjelenő negatív és pozitív említések számának $(\mathrm{db})$ kapcsolata a véleményekhez és a vásárláshoz köthető metrikus adatokkal - E-termék vásárlása ( $\mathrm{N}=100$ komment)

70. táblázat: Az azonos termékkategóriában történő vásárlások összehasonlítása a vélemények tartalma alapján - Offline-termék vásárlása ( $\mathrm{N}=100$ vélemény).

71. táblázat: Az azonos termékkategóriában történő vásárlások összehasonlítása a vélemények tartalma alapján - E-termék vásárlása $(\mathrm{N}=100$ vélemény).

72. táblázat: A minőségészlelés, az elégedettség és következményeinek kapcsolata az offline és e-termék vásárlása esetében - PLS-SEM ( $\mathrm{N}=100$ fö)

73. táblázat: A minőségészlelés, az elégedettség és következményeinek alakulása az első és az újravásárlás esetében - PLS-SEM ( $\mathrm{N}=100$ fó) ........................................... 155

74. táblázat: A hipotézisvizsgálat eredménye a nagymintás kutatás eredményei alapján - PLS-SEM módszertan alkalmazásával.

75. táblázat: A hipotézisvizsgálat eredménye a nagymintás kutatás eredményei alapján - PLS-SEM, MGA módszertan alkalmazásával.

76. táblázat: A hipotézisvizsgálat eredményei - kísérleti és nagymintás kutatás összehasonlítása 


\section{Köszönetnyilvánítás}

Munkám elkészitése és az elmúlt évek támogatása miatt első sorban szeretnék köszönetet mondani témavezetömnek, Simon Juditnak. Köszönöm a teljes családomnak és a férjemnek is, hogy mellettem álltak, jó tanácsaikkal, megértésükkel, és türelmükkel támogatták a munkámat, és az értekezés elkészitését. Természetesen minden barátomnak és kollégámnak is köszönettel tartozom a segitségükért. 


\section{BEVEZETÉS}

Világunk már a '90-es évek közepén digitálissá vált (Szabó - Hámori, 2006, 66. oldal), mely fejlődés jelentősen meghatározza a gazdaság átalakulását, folyamatosan új súlypontok jelennek meg. A vállalatok értékesítési folyamatában az internet napjainkban kiemelkedő szerepet játszik az információgyüjtési szakasz támogatásától egészen a vásárlásig, a rendelés utánkövetéséig, vagy akár a termékek, szolgáltatások igénybevételéig (pl. szoftverek, e-banking). A vállalatok egy részének az online környezet a hagyományos, offline üzletük mellett egy alternatív megoldást jelent az értékesítésben (pl. bevasarlas.tesco.hu); mások kizárólag a márka támogatására használják az internetet (pl. axe.hu), vagy egy kiterjesztett, időtakarékos megoldásként alkalmazzák (pl. e-banking). Azonban egyre jelentősebb azoknak a cégeknek a száma, akik kizárólag az online környezetben értékesítenek (pl. amazon.com).

Az internetes vásárlói oldalak, az ún. webshopok olyan online honlapok, ahol a fogyasztók böngészhetnek, értékelhetnek, megrendelhetnek egy terméket vagy szolgáltatást, vagyis ezek a fizikai boltok cyber változatai, ahol a vásárlás minden lépése megvalósítható (Yoo - Donthu, 2001).

Clark (1997) szerint ezeket a honlapokat 6 kategóriába sorolhatjuk:

1. termelői/gyártói honlapok, ahol a cégek adják el a saját termékeiket (store.apple.com/hu);

2. offline „brick-and-mortar” kereskedők, amelyek online is elérhetővé teszik a termékeiket (groby.hu);

3. hibrid katalógusos honlapok, ahol a nyomtatot katalógus online is elérhető (avonplaza.hu);

4. tiszta ,.com” eladók, akik több gyártó termékeit adják el, és nincs fizikai boltjuk (amazon.com);

5. „pláza oldalak”, amelyek a felületet biztosítják a cégeknek, és ezért pénzt kérnek az eladóktól (trivago.hu);

6. online alkuszok (biztositas.hu).

Az online boltok és vásárlók száma az elmúlt években rohamosan nőtt. Eleinte ebben az új környezetben a siker kulcsát az online jelenlét és az olcsó árak jelentették (Minocha et al., 2003; Kim et al., 2006), azonban a fogyasztói igények változásával és az online 
jelenléttel (is) bíró cégek számának növekedésével a versenyképes működés szempontjából a fogyasztói igények minél magasabb szintü kielégítése, a minőség és az elégedettség kérdése került a fókuszba (Zeithaml et al., 2002).

A kínált elektronikus szolgáltatások mélységétől függetlenül a versenyképesség szempontjából meghatározó kritérium, hogy az adott honlapot a fogyasztók hatékonynak, illetve célravezetőnek értékeljék, amit a fogyasztói elégedettség szintjének folyamatos mérése támogathat. A szolgáltatásmarketing témakörébe tartozó kutatások alapján megállapítható, hogy a meglévő ügyfelek megtartása sokkal kevesebb költséget jelent, mint újak szerzése, így az elégedettség növelésével a vállalatok profitja növelhető, illetve ez a hosszú távú siker kulcsaként is szolgál (Carlson - O’Cass, 2011; Christodoulides Michaelidou, 2011; Teimouri et al., 2012). A versenyképesség területéhez tartozó tanulmányok, illetve kutatások folyamatos fejlesztése és szélesítése a gazdaság fejlődése szempontjából is kiemelkedő szereppel bír (Chikán et al., 2002), ezért fontos, hogy az online lehetőségeket, melyek a jelen és jövő meghatározó területei, részletesen megvizsgáljuk.

Az elektronikus kereskedelemhez az elektronikus üzleti akciók tartoznak (Kápolnai et al., 2002), és az elmúlt években ennek szerepe, valamint az online eladások értéke folyamatosan nőtt. Az Eurostat eredményei alapján 2012-ben az EU27 országokban a lakosság 44\%-a vásárolt valamilyen terméket vagy szolgáltatást online az adatfelvétel előtti egy év során, mely 2010-hez képest 4 százalékpontos emelkedést jelentet. A legmagasabb arány Norvégiában (76\%), a legalacsonyabb pedig Romániában (5\%) volt. Magyarországon a lakosság 25\%-a vett valamit az elmúlt egy év során online (Eurostat 2013), továbbá az NRC 2009-es E-commerce Trendriportja azt is kimutatta, hogy a legalább hetente internetezők 67\%-a vásárolt már valaha az interneten (NRC 2009).

A magyarországi webáruházak forgalmát 2011-ben 155 milliárd forintra becsülték, mely a 2010-es forgalomhoz képest több mint 20 milliárd forintos növekedést jelent (Enet, 2010, 2011). Ehhez képest 2012-ben már 177 milliárd forintot költöttek el a vásárlók a kosaras rendszerben müködő webshopokban, és megközelítőleg 6.000 magyar nyelvü webáruház érhető el jelenleg az interneten (Enet, 2013). Amennyiben a 2005 és 2010 közötti periódust vizsgáljuk, megállapítható, hogy míg a kiskereskedelmi iparági átlag 10\%-os csökkentést mutatott, addig az elektronikus kiskereskedelem volumene hétszeresére nőtt, mely Nemeslaki szerint „drámai átrendeződést” jelent a 
kiskereskedelem területén (Nemeslaki, 2012, 196. old). 2011-ben a teljes kiskereskedelmi forgalom 2,4\%-át tette ki az elektronikus kereskedelem (Enet, 2012).

Magyarországon 2011 III. negyedévében a havi legalább egy órát internetező 15-69 éves lakosok száma - őket nevezzük online fogyasztóknak - csaknem 4,5 millió fő volt, és a naponta internetezők aránya is elérte a 3 millió föt. Az internetezők 62\%-a vásárolt valamilyen terméket az elmúlt 1 évben a világhálón - ők az online vásárlók (nrc.hu, 2012). Ezek az adatok is mutatják, hogy az online fogyasztók és online vásárlók kategóriája kezd lassan összeolvadni (Szücs, 2011).

Az online és offline környezet különböző élményt nyújt ugyanazon termék vásárlása esetében. Az e-kereskedelem kényelmet kínál az idő és a hely tekintetében, valamint a szállítással/kézhezvétellel kapcsolatban (Grewal et al., 2001, in: Wolfinbarger - Gilly, 2002), azonban az offline környezetben jelen lévő személyes interakciók, illetve a kipróbálás lehetősége itt elvész, ezért akik szeretik látni, megérinteni a terméket, azok sokkal kevesebbet vásárolnak a világhálón (Shayesteh et al., 1999). Az online vásárlás inkább magányos, tervszerű folyamat, mintsem társadalmi, szociális esemény. Ennek ellenére a személyre szabás lehetősége, a közösséghez tartozás, a versenyképes árak számos előnyt kínálnak, ezenkívül az interneten több információ és értékesítő érhető el rövidebb idő alatt (Wolfinbarger - Gilly, 2003; Qin, 2007). Kuttner (1998) szerint az internet egy közel tökéletes piac, mivel az információk azonnal elérhetőek, és ezeket, valamint az árakat a vásárlók világszerte össze tudják hasonlítani (in: Srinivasan et al., 2002; Qin, 2007). Ezt a folyamatot tovább könnyítik az összehasonlító oldalak - főleg az offline lehetőségekhez képest -, és a váltási költségek is alacsonyabbak (Kwon - Lennon, 2009).

Az e-kereskedelem céljai közé sorolható, hogy az interneten keresztül minél hatékonyabban juttasson el információkat a fogyasztóhoz. Az információ egy üzenet, amelyet a küldő küld egy fogadónak valamilyen csatornán keresztül (Barnes - Vidgen, 2000). A fogyasztók azonban nem csak megkapják, és összegyüjtik ezeket (pull), hanem újakat oszthatnak meg, véleményeket is közölhetnek (push), ezzel befolyásolva a potenciális vásárlókat. Az interneten tehát a felhasználók információnyújtók és fogyasztók is.

Az e-kereskedelem azonban nem egy homogén terület, számos csoportosítási lehetősége létezik. Csoportképző ismérvnek lehet tekinteni a vásárolt jószág jellegét, a vállalat 
internethasználati szokásait (tiszta online vagy vegyes online jelenlét) vagy az alkalmazott modellt (pl. Groupon-modell), és az ezek alapján meghatározott szegmensekben érdemes a különböző mechanizmusok müködését elkülönítetten vizsgálni. Francis és White 2003-ban alkotta meg az e-kereskedelem marketingközpontú kategorizálását, melynek során a vásárolt jószág jellege, illetve igénybevétele (offline vagy online) alapján négy szegmenst különítettek el: az offline-termékek, az elektronikus-termékek, az offline-szolgáltatások és az elektronikus-szolgáltatások piacát. Kutatásuk során felhívják a figyelmet, hogy az e-kereskedelem marketingszempontú elemzéseinél érdemes a megalkotott csoportok közötti eltéréseket górcső alá venni.

\subsection{A kutatás célja}

Jelen Ph.D. kutatás célja megvizsgálni egy az offline világból már jól ismert kapcsolatrendszer alakulását különböző e-kiskereskedelemi szegmensek esetében. A munka során feltárásra kerül, hogy a Francis és White (2003) által meghatározott négy ekereskedelmi kategóriában, vagyis az offline-termékek, az offline-szolgáltatások, az elektronikus-termékek, valamint az elektronikus-szolgáltatások piacán megvalósult vásárláshoz köthetően mely elektronikus szolgáltatásminőség dimenziók a relevánsak, illetve ezeken a területeken elkülönítve, illetve egymáshoz viszonyítva hogyan alakul az újravásárlási, valamint a hagyományos és elektronikus továbbajánlási szándék az elégedettség függvényében. A kutatás fő motivációja tehát feltárni a négy elektronikus kereskedelmi kategória közötti hasonlóságokat és a legjelentősebb eltéréseket, kvázi a különböző e-kereskedelmi szegmenseket a modellben mint moderáló változót értelmezni.

A lojalitás témakörét azért nem elemezzük a disszertáció keretében, mert az egy hosszabb távú kapcsolat eredményeként értelmezhető (Oliver, 1999; Vallejo et al., 2005), jelen esetben viszont a rövid távon kialakuló vásárlói szándékok és viselkedések megértése, és magyarázata a cél.

A tanulmány célja kettős. Az akadémiai szakirodalomban az e-kereskedelem differenciált vizsgálata számos esetben igényként, jövőbeli kutatási irányként került megnevezésre (Francis, 2007, 2009). Az észlelt minőség, az elégedettség, az újravásárlás és a továbbajánlás különböző e-kereskedelmi szegmensekben történő elemzésére eddig kisszámú tanulmány született, és jelen tanulmány ezt a hiányt szeretné pótolni. A munka másik célja, hogy a hazai sajátosságokat figyelembe véve vizsgálja meg a területet. Magyarországon az e-kereskedelem a folyamatos fejlődése ellenére is kevésbé elterjedt, 
mint a nyugati országokban, mások az online fogyasztók jellemzői (1. és 2. melléklet), és ezek jelentősen befolyásolhatják az elvárásokat, valamint a minőségészlelés dimenzióit. A témaválasztást befolyásolta, hogy már egyetemista korom óta érdeklődöm az újfajta, online megoldások iránt, és a vállalatok számára jelentős feltörekvési lehetőséget látok az e-kereskedelemben. A szakirodalomban is több kutatás született már a témában, azonban úgy gondoljuk, hazánkban a korábban megfogalmazott témakör alapos ismerete akadémiai és gyakorlati szempontból sem jellemző.

\subsection{A kutatás elméleti és gyakorlati vonatkozása}

Jelen kutatás nemcsak az akadémiai ismeretanyagok körében fellelhető hiányosságokat pótolja, hanem az e-kiskereskedelmi vállalatok számára egyfajta útmutatót is tartalmaz, mivel a tanulmány a minőségészlelés szempontjából releváns dimenziókat járja körbe és mutatja be hatásukat az elégedettség, illetve annak pozitív következményei esetében. Az internetes értékesítők sikeressége a fogyasztói igények minél alaposabb feltérképezésétől és adaptálásától is függ (Zeithaml et al., 2002; Reichheld - Schefter, 2000), tehát a minőség a stratégia kiemelt mozgatóeleme, és a verseny egyik kulcstényezője. Az információs és kommunikációs technológiák (IKT) fejlődése és a folyamatos változások során a sikeres és tapasztalt vállalatok egy része megértette, hogy a profitabilitás egyik kulcsa a magas elektronikus szolgáltatásminőség közvetítése lehet (Teimouri et al., 2012). A szolgáltatás összeomlásával, az elvesztett rendelésekkel, vagy a nem megfelelö panaszkezeléssel elégedetlen vásárlók a céget könnyen elhagyják, hisz a versenytársak csak egy kattintásnyira vannak (Meuter et al., 2000; Bauer et al., 2006). Online környezetben a vásárlás inkább az ajánlás következménye, mintsem az eladóval folytatott interakcióé (Smith et al., 2005), illetve a blogok, a közösségi média és a közösségek is jelentős hatással vannak a vásárlási döntésre (Herring et al., 2005; Bernoff - Li, 2008). Emiatt az újravásárlási és a hagyományos továbbajánlási hajlandóság mellett kiemelkedő jelentőségű az elektronikus továbbajánlási szándék vizsgálata is.

\subsection{A dolgozat felépítése}

A dolgozat három nagy részből áll. Az elsőben a szakirodalmi összefoglaló található, a második a kutatási tervet és designt mutatja be, míg a harmadikban kerül sor az empirikus kutatási eredmények, azaz a nagymintás online lekérdezés és a kísérlet eredményeinek ismertetésére. 
A szakirodalmi összefoglaló első fejezetében (2.1. fejezet) az általános minőségészlelési koncepciók kerülnek bemutatásra, kiemelt szerepet szánva az offline és az online területek közti hasonlóságoknak, illetve eltéréseknek. A második fejezet (2.2. fejezet) az e-kereskedelem marketing szempontból releváns aspektusait ismerteti, a középpontban az elektronikus vásárlási folyamattal, melynek megértése az elektronikus szolgáltatásminőség koncepció tökéletes adaptálásához szükséges. Ezeknek az alappilléreknek a tisztázása utána kerül sor a 2.3. fejezetben az elektronikus szolgáltatásminőség koncepciók részletes kronológiai fejlődésének bemutatására, illetve ezen megközelítések értékelésére és összegzésére az elfogadott e-szolgáltatásminőség definíció tükrében. Ezek a koncepciók azért kerülnek ilyen részletesen és leíró jelleggel bemutatásra, mert ismeretük a vállalatok számára jelentős információkat hordoz a minőségészlelés mérése, illetve a lehetséges fejlesztési területek tekintetében.

A 2.4. fejezet már a minőségészlelés és az elégedettség kapcsolatát mutatja be korábbi kutatások alapján. A köztük lévő kapcsolatrendszer ismertetése után kerül sor az elégedettségkoncepciók felvázolására. Az összefoglaló utolsó része, a 2.5. fejezet foglalkozik az elégedettség következményeivel, melyek különböző magatartási formákban nyilvánulhatnak meg. A jövőbeli viselkedési modellek ismertetése után az empirikus kutatás középpontjában álló újravásárlási, valamint hagyományos és elektronikus továbbajánlási szándék leírása következik.

A szakirodalmi összefoglalás alapján kerül sor a 3. fejezetben az empirikus kutatási terv megalkotására, illetve részletes ismertetésére, kiemelt szerepet szánva a kiinduló hipotézisek létrehozásának, a változók operacionalizálásának, illetve a tervezett kutatási módszertan ismertetésének.

A disszertáció következő fejezte (4. fejezet) a megvalósított empirikus kutatásokat mutatja be, majd a záró fejezetben kerül sor a legfontosabb eredmények összefoglalására és a menedzseri következtetések összefoglalására. 


\section{SZAKIRODALMI ÁTTEKINTÉS}

A szakirodalmi összefoglaló íve az általános elméleti keretektől tart a konkrét, a kutatás során is alkalmazott koncepciók, illetve függő változók bemutatása felé (1. ábra). Az elméleti összefoglalás öt részre bontható. Az első fejezet célja, hogy a minőségészlelési koncepciók ismertetésével bemutassa az offline és online környezetbeli legfontosabb különbségeket, és meghatározza az elektronikus kereskedelemhez kapcsolódó minőség definícióját. A második fejezet az elemzés környezetéül szolgáló elektronikus kereskedelem marketingszempontú ismertetését tartalmazza, hangsúlyozva a vásárlási folyamat alakulását, melynek megértése a korábban bemutatott elektronikus szolgáltatásminőség koncepció központi eleme. Ezeknek az elméleteknek az ismeretében lehetséges az elektronikus szolgáltatásminőség mérésére szolgáló skálák értékelése, és az elfogadott definíció szempontjából legalkalmasabb skála megtalálása.

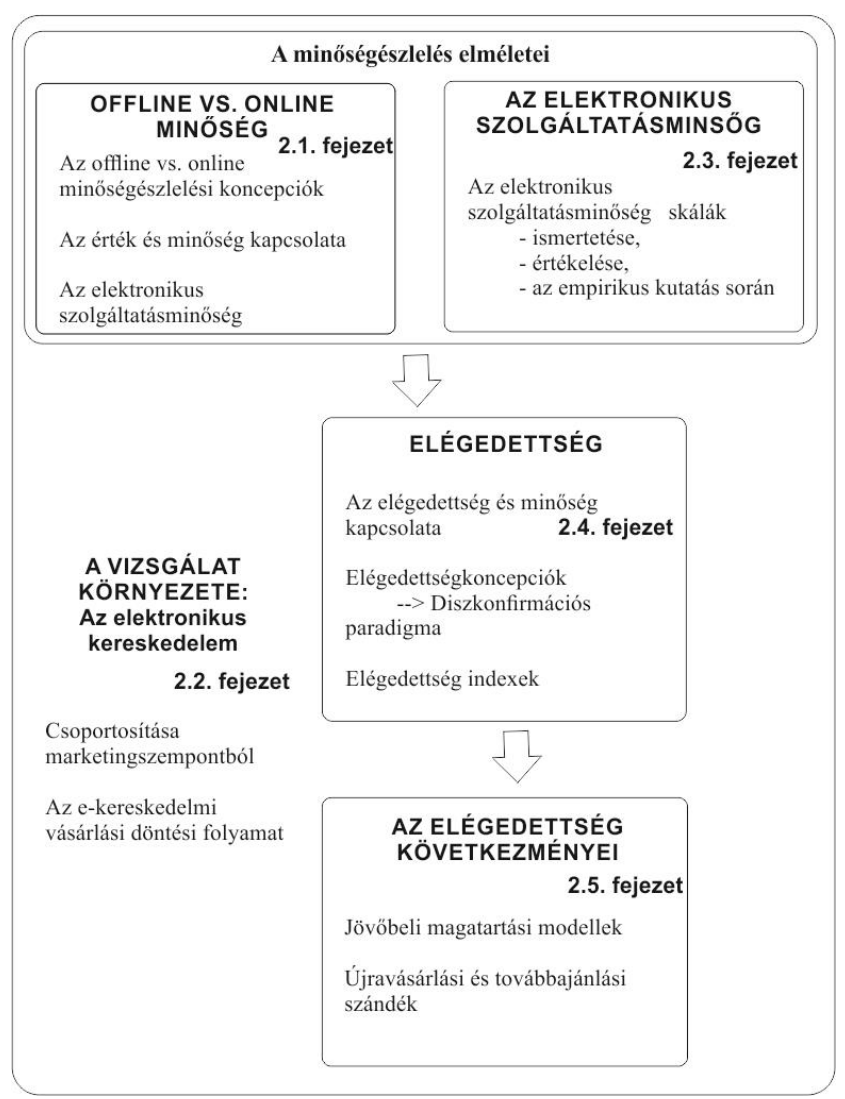

1. ábra: Az irodalmi összefoglaló íve

Forrás: saját szerkesztés 
A következő fejezet a minőségészlelés utáni fogyasztói állapotot, az elégedettség szintjét és elméleteit járja körbe, és ezután kerül sor az elégedettség koncepcióihoz tartozó következmények ismertetésére, kiemelt szerepet szánva az újravásárlási szándéknak, illetve a szájreklámnak.

\subsection{A minőség szerepe a vállalati müködésben}

Témám megválasztásakor igyekeztem egy olyan területet keresni, melynek vizsgálata az akadémiai modellek finomítása mellett számos útmutatást is tartalmaz a sikeres vállalati müködéshez. A cégeknél az egy fogyasztóra jutó kezdeti tranzakciós költségek a meggyőzés miatt magasak, azonban a későbbiek során ezek csökkennek, és a kapcsolat profitot termel (Srinivasan et al., 2002). Ezt Strauss és társainak megállapítása is alátámasztja, mely szerint az új fogyasztók megnyerése ötször annyiba kerül, mint a megtartásuk (Christodoulides - Michaelidou, 2011). Az online piacon a versenytársak csak egy kattintásra vannak, így sokkal több ajánlat közül válogathatnak a vásárlók, emellett az új ügyfelek szerzése nehezebb, és a költségei is magasabbak, mint az offline közegben (Fu-Ling - Chuan, 2012; Christodoulides - Michaelidou, 2011). Reichheld és Schefter (2000) szerint online környezetben az új ügyfelek meggyőzése 20-40\%-kal többe kerül, mint a hagyományos, offline piacon. Az elégedett visszatérő vásárlók számának növekedésével tehát csökkenhetnek a vállalat marketingköltségei, egyszerübben zajlanak le az üzletek, és ez a versenyben is segít jobban helytállni (Liu Arnett, 2000).

Az elégedett, illetve visszatérő vásárlók jobban megértik, ha valami baj van, hajlandóbbak magasabb árat fizetni a termékért/szolgáltatásért (Chow - Reed, 1997; Reichheld - Schefter 2000; Zeithaml et al. 1996; Gefen 2002), könnyebb ismét elégedetté tenni őket, mert a cég jobban ismeri elvárásaikat (Zeithaml et al. 1996; Demeter, 2009), emellett sokkal nagyobb valószínüséggel ajánlják az üzletet másoknak is, amivel a vállalati reklámot segítik (Zeithaml et al. 1996; Gefen, 2002). Az elégedett vevők a vállalat vevőkapcsolati tőkéjét jelentik, amit napjainkban egyre több cég felismert (Kotler - Keller, 2012). A minőség az elégedettség kialakulásának egyik alappillére (Wolfinbarger - Gilly, 2003), ezáltal a hosszú távú sikeres teljesítés (Fassnacht - Koese, 2006; Santos, 2003; Wolfinbarger - Gilly, 2003; Zeithaml et al., 2000, 2002; Ladhari, 2010) és versenyképesség (Bressolles - Nantel, 2006) egyik kiemelt tényezője. 


\subsection{A hagyományos szolgáltatásminőség megközelítéstől az elektronikus szolgáltatásminőségig}

Az elektronikus kereskedelemhez tartozó szolgáltatásminőség dimenzióinak pontos meghatározásával kapcsolatban a szakirodalomban még nem született konszenzus, általános elvként azonban mindegyik megközelítés a hagyományos szolgáltatásminőség alapgondolatait használja fel.

Az észlelt szolgáltatásminőség a fogyasztói elvárások és a tapasztalt vállalati teljesítmény közötti különbségként értelmezhető (Parasuraman et al.,1985; Parasuraman et al., 2005; Kim et al., 2006). Az értékelés során tehát a fogyasztó elvárásai kiemelt szereppel bírnak, melyet a korábbi tapasztalatai, a szituációs hatások, a vállalati kommunikáció és a szájreklám befolyásolnak (2. ábra) (Kenesei - Kolos, 2007).

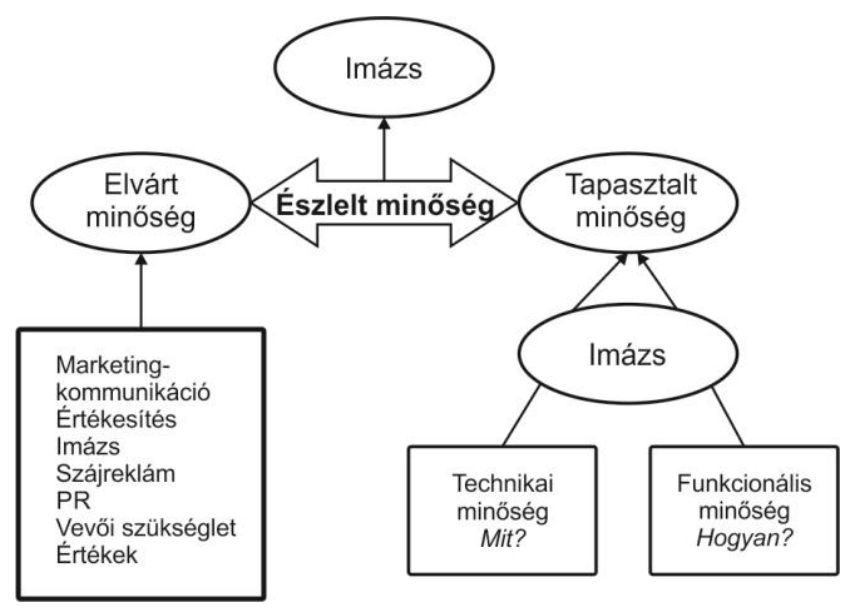

\section{2. ábra: Az elvárt és tapasztalt minőséget befolyásoló tényezők}

Forrás: Kenesei-Kolos (2007), 133. old.

A sikeres vállalati müködős feltétele, hogy a fogyasztók minél jobbnak ítéljék meg a termékekhez, szolgáltatásokhoz kapcsolódó minőséget. Ehhez a minőségészlelés folyamatos mérése szükséges, melynek segítségével a minőségproblémák feltárhatóak és javíthatóak lesznek. Ezek a folyamat több pontján jelentkezhetnek, és erre utal az ún. réselemzési technika (GAP-modell) (Kenesei - Kolos, 2007). A Parasuraman és társai által megalkotott résmodell (1985) négy szakadék mentén definiálja a szolgáltatásminőség eltéréseit (3. ábra):

1. szakadék (G1): az ismereti rés, amely a fogyasztói elvárás és a vállalati menedzsment által észlelt fogyasztói elvárás közötti szakadékot jelöli. 
2. szakadék (G2): a sztenderdek rés, amely a vállalati menedzsment által észlelt fogyasztói elvárás és a szolgáltatásminőség specifikálása közötti különbséget jelenti.

3. szakadék (G3): a teljesitési rés, amely a szolgáltatásminőség specifikálása és a tényleges, nyújtott szolgáltatásminőség közti különbséget takarja.

4. szakadék (G4): a kommunikációs rés, vagyis a kommunikált minőség és a ténylegesen nyújtott minőség közti különbség.

A modellben az utolsó szakadék (G5) mutatja meg, hogyan alakul az egyén értékelése a minőséggel kapcsolatban (Parasuraman et al., 1985; Bauer et al., 2007; Veres, 2009).

A megnevezett szakadékok tehát a különböző elképzelések miatt alakulhatnak ki, és ezeknek csökkentésére, illetve optimalizálására kell a vállalatoknak törekedni. Ez azonban nagy kihívást jelent, mivel az észlelés folyamata fogyasztónként és helyzetenként változik.

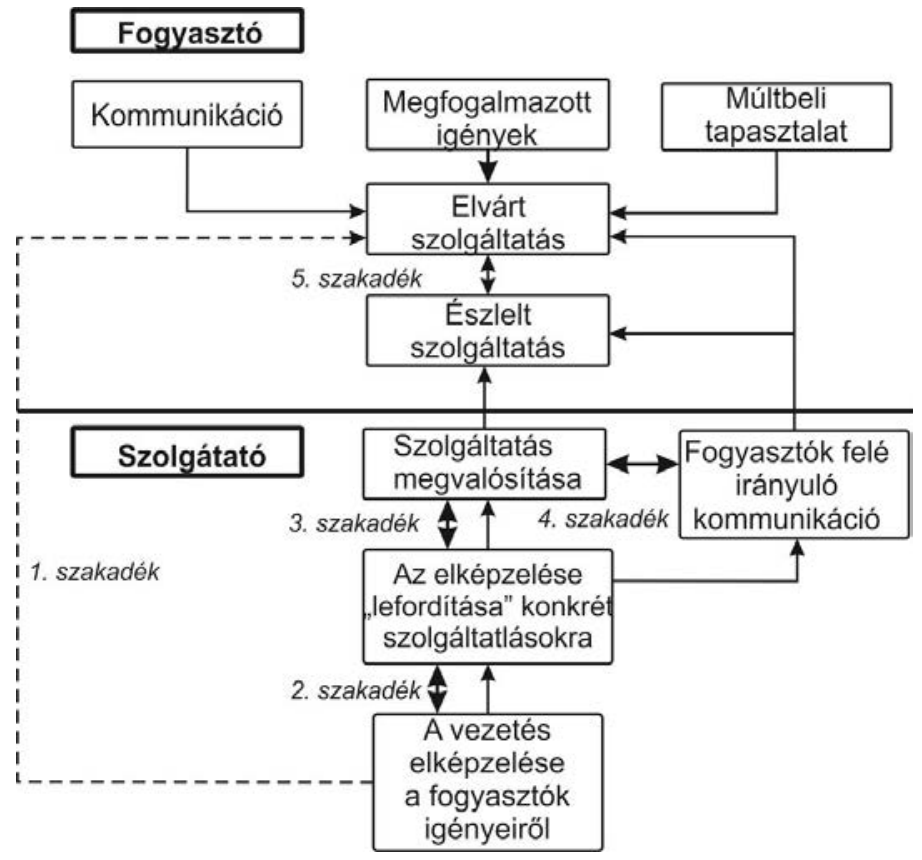

3. ábra: A rés- (GAP) modell

Forrás: Hofmeister-Tóth et al. (2003), 42. old

A tradicionális szolgáltatásminőség mérésére offline környezetben legtöbben a SERVQUAL skálát használják (Parasuraman et al., 1988, 1994; Zeithaml et al., 1996; Carman, 1990; Cronin - Taylor, 1992; Parasuraman et al., 2005), mely egy standardizált kérdőíven alapszik, 22 kérdéspárt két külön részben tartalmazva (Parasuraman et al., 1985). Az első a minőségelvárásokkal foglalkozik, a második pedig az átélt folyamat 
fogyasztói értékelésére kérdez rá. Az észlelt minőség alakulását ennek a két tényezőnek a különbsége adja, vagyis:

$$
\text { Észlelt minőség = Elvárt minőség - tapasztalt minőség. }
$$

A kérdéspárok öt csoportba sorolhatóak, melyek a tradicionális szolgáltatásminőség legfőbb jellemzőit fedik le. Ezek (1) a megfogható elemek, (2) a megbízhatóság, (3) a hatékonyság, (4) a biztonság és (5) az átélés (Kenesei - Kolos, 2007). A skálát különböző kontextusokban tesztelték már (Vallejo et al., 2005).

\begin{tabular}{|l|l|}
\hline $\begin{array}{l}\text { HAGYOMÁNYOS } \\
\text { SZOLGÁLTATÁSMINÖSÉG }\end{array}$ & \multicolumn{1}{|c|}{$\begin{array}{c}\text { ELEKTRONIKUS } \\
\text { SZOLGÁLTATÁSMIINÖSÉG }\end{array}$} \\
\hline \multicolumn{2}{|l|}{ Hasonlóság } \\
\hline $\begin{array}{l}\text { A fogyasztói megítélést az elvárt minőség és nyújtott minőség/teljesítmény közötti } \\
\text { különbség határozza meg. }\end{array}$ \\
\hline Különbség & Ember-gép interakció \\
\hline Interperszonális kapcsolat & $\begin{array}{l}\text { Találkozáskor technológia áll a } \\
\text { középpontban }\end{array}$ \\
\hline Találkozáskor tárgyi környezet, emberek & Az önkiszolgálás nagyobb szerepet kap \\
\hline & $\begin{array}{l}\text { Interperszonalitás hiánya } \rightarrow \text { a kockázat } \\
\text { tovább nő }\end{array}$ \\
\hline
\end{tabular}

\section{1. táblázat: A hagyományos és az online szolgáltatásminőség összehasonlítása}

Forrás: szakirodalom alapján saját készités

Online környezetben egy termék vagy szolgáltatás vásárlása más élményt nyújt, mint hagyományos, offline környezetben. Ilyenkor a vásárlók az üzlettel a virtuális térben „kommunikálnak”, az interperszonális interakció helyét ember-gép interakció veszi át, melynek középpontjában a technológia áll (Bressolles et al., 2007, Skiera, Spann, és Walz, 2005), és megnő az önkiszolgáló (self-service) metódusok jelentősége (Meuter et al., 2001). Az internet csatornaként számos újfajta előnyt nyújt, mint például a kétirányú kommunikáció, a személyre szabás, a közösség szerepe, valamint a növekvő információés termékválaszték, melyek szintén egy újfajta, az offline-tól eltérő minőségmegközelítést követelnek (Wolfinbarger - Gilly, 2003). Az internetes vásárlás előnyei, úgymint a 24/7 elérhetőség (Seiders et al., 2000), az összehasonlítási lehetőségek (Wolfinbarger - Gilly, 2001; Zeithaml et al., 2000) vagy az önkiszolgálás a kontroll érzetét nyújtják, illetve egyfajta szabadságot biztosítanak az eladóktól, a családtól, a szociális érintkezésektől. Azonban hátrányai is léteznek a folyamatnak, például a kiválasztott terméket nem foghatjuk meg, nem beszélhetünk az eladókkal. Ebben a személytelen, automatizált környezetben kevesebb direkt érzéki stimulus éri a vásárlókat, valamint a csalási és visszaélési lehetőségek miatt nagyobb a bizonytalanság érzete, így 
kiemeltebb figyelmet kap a biztonság kérdése (Bressolles et al., 2007). Ezen sajátosságok alapján megállapítható, hogy az elektronikus kereskedelemhez tartozó szolgáltatásminőség a tradicionálistól eltérő megfogalmazást igényel. A legfontosabb különbségeket a 1. táblázat foglalja össze.

A résmodellben (GAP) felrajzolt szakadékok az elektronikus szolgáltatásminőség esetében is tetten érhetőek (Zeithaml et al. 2002), és ezek együttes hatása befolyásolja a szolgáltatásminőség értékelését $(\mathrm{G} 5=\mathrm{f}(\mathrm{G} 1 ; \mathrm{G} 2 ; \mathrm{G} 3 ; \mathrm{G} 4))$, mely hatással bír az elégedettségre, ezáltal pedig a továbbajánlásra és az újravásárlásra (4. ábra).

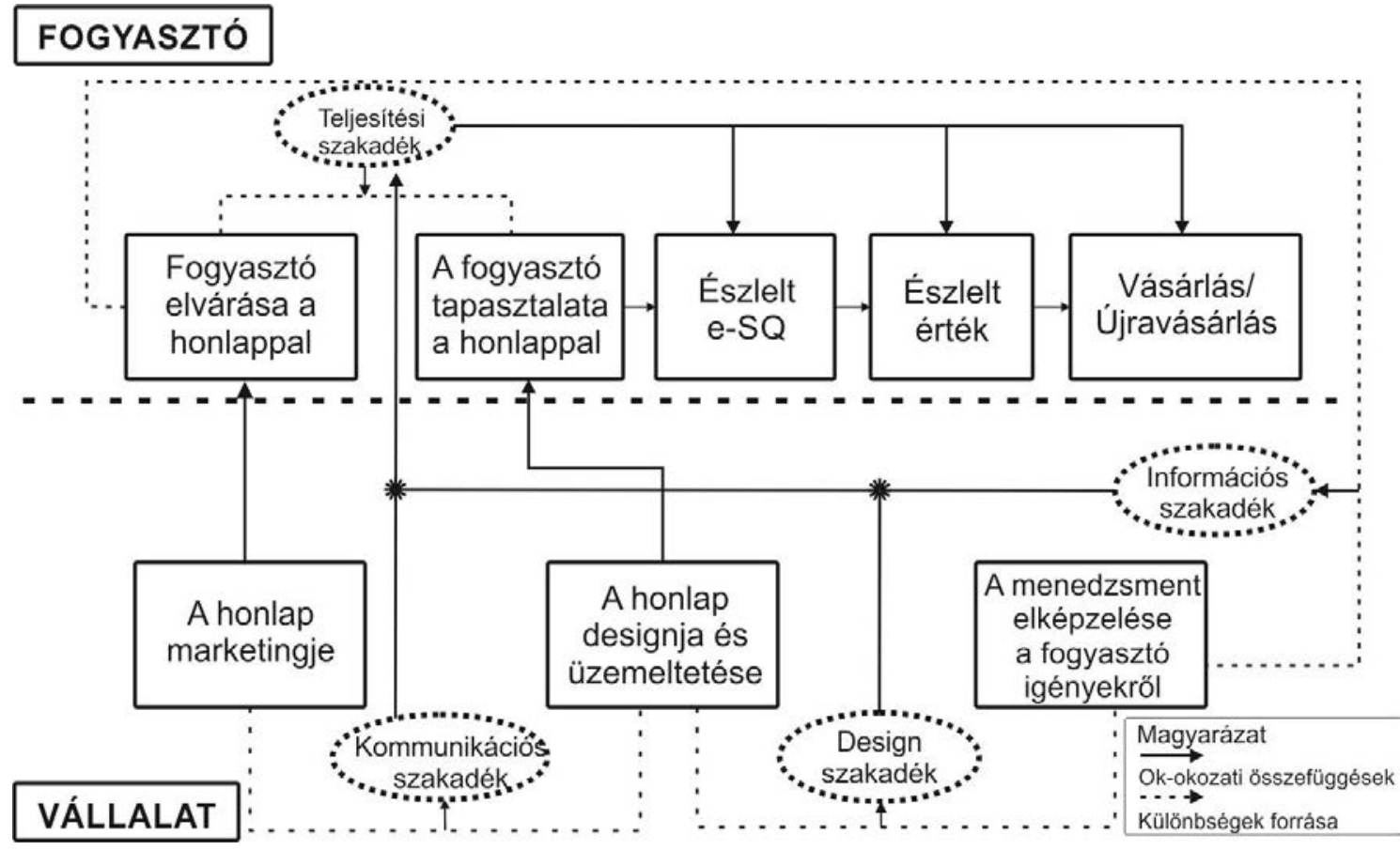

\section{4. ábra: A résmodell alakulása az elektronikus kereskedelem esetében}

Forrás: Zeithaml et al. (2002)

Parasuraman, Zeithaml és Malhotra (2000, 2005) véleménye szerint az elektronikus szolgáltatásminőség értelmezésénél is figyelembe kell venni, hogy a minőségészlelést az befolyásolja, hogy a vásárlók mit várnak el, és hogyan alakul a tapasztalt teljesítmény. Ennek függvényében érdemes megvizsgálni, hogy a hagyományos szolgáltatásminőségdimenziók közül melyek értelmezhetőek az e-szolgáltatásminőség esetében, illetve milyen új aspektusok jelennek meg.

\subsubsection{Az érték és a minőség kapcsolata}

Az online közegben kialakuló minőségdefiníció ismertetés előtt célszerü az érték és a minőség kapcsolatrendszerét tisztázni. A szakirodalomban az érték és a minőség mérése 
kapcsán sokszor hasonló vagy ugyanolyan megoldásokkal találkozhatunk (Gyulavári, 2005), azonban mégis érdemes a két fogalmat külön értelmezni. Az érték a marketing egy jelentős eleme a minőséghez, az elégedettséghez, illetve a lojalitáshoz füződő viszonya miatt (Cronin et al., 2000; McDougall - Levesque, 2000), mely magában foglalja, hogy mit kapott a fogyasztó (fogyasztói output) azért, amit adott (fogyasztói input) (Zeithaml, 1988; Oliver - DeSarbo, 1988). Az értéket tehát „a minőség, a kiszolgálás és az ár kombinációjának tekinthetjük, melyet a »vevöérték hármasának « neveznek” (Kotler Keller, 2008, 62. old). Amennyiben a minőség és a kiszolgálás javul, az érték is nő, míg az ár növekedésével csökken. A marketing szempontjából a fogyasztói észlelt érték bír kiemelt szereppel (Rekettye, 1997). Habár létezik olyan definíció, amely az érték fogalmába nem integrálja a ráfordításokat, mégis a vásárlási folyamat során, amikor egy termék vagy szolgáltatás kiválasztását szükséges eldönteni, akkor a ráfordítások figyelembevétele is jelentőséggel bír (Gyulavári, 2005).

$\mathrm{Az}$ érték vásárlásonként változhat, ezért fontos megérteni a vevői motivációkat. Két jelentős motivációt különböztetnek meg a vásárlás során: a haszonelvüt és az élvezetit, vagy más néven hedonistát (Hirschman - Holbrook, 1982). Az elöbbi célvezérelt, racionális, ahol a vásárlás egy feladat vagy kötelezettség (Babin et al., 1994). Ebben az esetben az érték abból adódik, hogy a tranzakció időben, hatékonyan teljesítésre kerül (Babin et al., 1994). A funkcionális, vagyis haszonelvü érték az értékek és áldozatok summázott értékét jelöli (Overby - Lee, 2006), mely kognitív elemeket tartalmaz, például pénz, időmegtakarítás (Fu-Ling - Chuan, 2012). A másik esetben a vásárlás során az élmény, a jókedv és az élvezet a lényeges (Babin et al., 1994; Childers et al., 2001). A vásárlási folyamat azonban sokszor mindkét jegyet is tartalmazhatja, például amikor egy kívánt terméket akciós áron tudunk megvenni (Babin et al., 1994).

Az internetes vásárlást a hedonista és a haszonelvü értékek szempontjából általában homogén tevékenységként jellemzik. Sokan úgy gondolják, hogy az online vásárlás egy haszonelvü, céltudatos, célorientált folyamat, melynek célja a termék leghatékonyabb módon történő megszerzése, vagyis hogy minél gyorsabban, és minél kényelmesebben tudják a legtöbb információt, és így a legjobb ajánlatot elérni a vásárlók (Babin et al., 1994; Childers et al., 2001; Wolfinbarger - Gilly, 2001; Szymanski \& Hise, 2000). Az online fogyasztók már sokkal tudatosabbak, ami az információkeresésben is megjelenik, és igyekeznek a legértékesebb ajánlatot megtalálni, mint például egy ingyenes szállítással ellátottat vagy a nagyon kedvezményeset (Fu-Ling - Chuan, 2012). Az online vásárlás 
haszonelvű értékei közé tartozik tehát az időspórolás, a pénzspórolás, a kényelmesség és a választék mélysége.

Ezzel szemben a hedonista érték a szórakozásra, az ábrándozásra (Overby - Lee, 2006) és az élményre koncentrál, ami online közegben is jelentős lehet. Francis és White (2003) kutatása is bizonyítja, hogy a haszonelvü megközelítés mellett a hedonista értékek is megjelennek az elektronikus vásárlás során, mint például a keresési, „,vadászási” folyamat, az egyedi, különleges termékek felkutatása, az online aukciókon való részvétel, illetve a chatszobákban, fórumokon a többi fogyasztóval való kommunikáció esélye. Ugyancsak a hedonista értékek közé sorolható még a vizuális élmény, az interaktivitás, a színek, a hangok (Childers et al., 2001; Menon - Kahn, 2002).

\subsubsection{Az elektronikus szolgáltatásminőség}

Ahogy azt a korábbi részben is bemutattuk, az e-kereskedelemhez tartozó szolgáltatásminőség-koncepció újfajta megközelítést igényel, mivel az offline értékesítéssel szemben számos sajátosságot tartalmaz. Az internet terjedésének korai szakaszában a cégek azt hitték, hogy az alacsony ár, illetve a webes jelenlét elegendő a sikerhez (Minocha et al., 2003; Kim et al., 2006). Az online környezetbeli fogyasztói és vállalati tapasztalatok gyarapodásával, a verseny élesedésével és az internetes vásárlás rutinná válásával (Yoo - Donthu, 2001) azonban rá kellett döbbenniük, hogy ez nem elég. Amennyiben a kívánt információk nem elérhetőek a honlapon, a vállalat nem válaszolja meg az e-maileket időben, vagy a terméket nem küldik a megígért időpontban, a fogyasztók sokkal alacsonyabban értékelik az adott cég által nyújtott minőséget (Zeithaml et al., 2002), és a jövőben az online vásárlásuk lebonyolításához a versenytársakat fogják választani. Ennek felismerése új stratégiai gondolkodást hívott életre, és hamarosan a minőség sarkalatos pontjává vált az internetnek mint csatornának. Azonban a szükséges szakirodalom a 2000-es évek közepéig hiányzott (Lennon - Harris 2002; Parasuraman et al., 2005).

A cybertérben számos honlapfajta létezik: online újságok, portálok, ingyen letöltési oldalak, C2C oldalak, linkgyüjtő oldalak, állásportálok, online vásárlási oldalak stb. A munka során, ahogy azt már a bevezetőben is említettük,a webshopokra koncentrálunk, tehát az olyan site-okra, melyeken vásárolni is lehet.

Online környezetben a vásárlási élmény kialakulásának folyamatát Minocha és társai (2005) öt szakaszban írják le (5. ábra): 
1. Elvárások csoportja: vagyis hogy az egyén milyen előzetes feltevésekkel, elvárásokkal rendelkezik, amelyeket motivációi, szükségletei, a hirdetések, a szájreklám, az észlelt előnyök, illetve hátrányok befolyásolnak.

2. E-vásárlás elötti szakasz: a honlap kiválasztása, termék/szolgáltatás keresése, információgyüjtés.

3. E-vásárlási szakasz: amikor a rendelkezésre álló információk alapján a vásárlás, fizetés megtörténik.

4. E-vásárlás utáni interakciók: a rendelés nyomon követése, érdeklődés, a rendelt termék kézhezvétele, reklamáció.

5. A termék/szolgáltatás elfogyasztása.

Az e-vásárlás környezetével, a webshoppal a fogyasztó az információgyüjtési, vásárlási, valamint a vásárlás utáni interakciók esetében közvetlenül találkozik, azonban a teljes élményt az előtte, valamint az utána lévő szakaszok is befolyásolják. Minocha és társainak modellje (2005) alapján a teljes online vásárlási folyamatot a vevő ennek az összképnek a függvényében értékeli, és dönti el, hogy újralátogatja-e a webshopot, illetve vásárol-e újra a webshopban, vagy inkább keres egy újat.

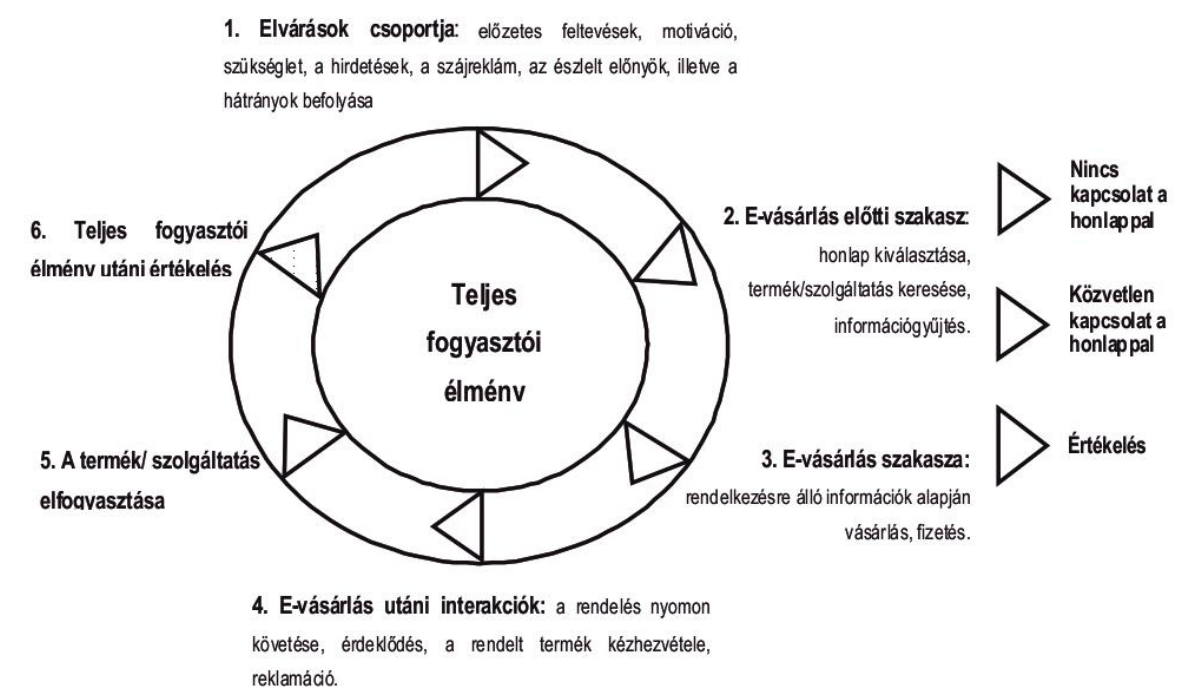

\section{5. ábra: A teljes fogyasztói élmény kialakulása online környezetben}

Forrás: Minocha et al. (2005), 31. old.

Számos egyéb kutató is egyetért azzal, hogy a minőség értékelése az online áruházak esetében nem csak a tranzakciókra korlátozódik, hanem az elektronikus szolgáltatások teljes skáláját magában foglalja (Montoya - Weiss et al., 2000; Wolfinbarger - Gilly, 2002; Zeithaml et al., 2002; Wolfinbarger - Gilly, 2003; Minocha et al. 2005, Bauer et 
al., 2005). Az elektronikus szolgáltatások minden olyan interaktív szolgáltatást tartalmaznak, amelyet az interneten közvetítenek a telekommunikáció, valamint az információs és a többcsatornás technológiák előnyeit használva (Sousa - Voss, 2006; Fassnacht - Koese, 2006). Ez azt jelenti, hogy a minőség értékelésekor a tranzakció közbeni események mellett figyelembe kell venni az ún. pre- és posztinterakciós szolgáltatási aspektusokat is, mint például az információgyüjtés folyamatát, a tranzakció teljesülését, az ügyfélszolgálatot vagy az esetleges visszatérítéseket, a problémák kezelését.

Ezek alapján a továbbiakban az e-kereskedelemhez kapcsolódó szolgáltatásminőséget a szakirodalomban is használatos elektronikus szolgáltatásminőség kifejezéssel illetjük, mely magában foglalja, hogy egy webshop milyen szinten képes a hatékony és eredményes nézelődést, vásárlást, illetve kiszállítást támogatni (Zeithaml et al., 2000), függetlenül attól, hogy terméket és/vagy szolgáltatást értékesít-e az adott shop.

Parasuramanék (2002) szerint az elektronikus szolgáltatásminőség esetében egy görbe pályájú kapcsolat figyelhető meg: míg offline esetben általában a legtöbbet akarják a fogyasztók elérni, addig online esetben van egy telítődési pont (invertált U-görbe). Az általuk felhozott példa szerint a vásárlók szeretnek visszajelzést kapni arról, hogy a rendelésüket elfogadták-e, valamint még az utánkövető e-mailek is rendben vannak, de van egy pont, amikor már elég a levelekből, és a további információáradat a minőség rontásához, ezen keresztül pedig az elégedettségük csökkenéséhez vezet.

Az elektronikus szolgáltatásminőség koncepciót tovább bonyolítja az e-kereskedelem többcsatornás jellege. Napjainkban egyre inkább egy többcsatornás környezetben élünk, ahol a fizikai, telefonos, internetes és egyéb csatornákat ötvözik. Tanulmányok bizonyítják, hogy akik kombinálják a különböző csatornákat, sikeresebbek tudnak lenni, mint egycsatornás versenytársaik (Sousa, 2010). Az elektronikus kereskedelem során a vásárlás, illetve a termék vagy szoláltatás kézhezvétele általában többcsatornás folyamatként jelenik meg, amelyben célszerü különbséget tenni a virtuális, a fizikai és az integrált minőség között.

Sousa (2006) véleménye szerint a többcsatornás megoldások miatt a virtuális és a fizikai csatornák fogalmát is el kell különíteni egymástól. A virtuális csatorna a kommunikáció azon eszköze, amelynek során a telekommunikációs, információs és multimédiás technológiák kerülnek felhasználásra. pl. az internet, interaktív eszközök (ATM, 
hotelbejelentkezés), az interaktív TV vagy a telefon. Ezzel szemben a fizikai csatornák esetében a fogyasztó egy fizikai infrastruktúrával találkozik, pl. face-to-face szolgáltatás, logisztikai infrastruktúrák.

Hasonlóan a csatornákhoz a nyújtott szolgáltatásokat is két csoportba sorolhatjuk. A virtuális szolgáltatás esetében az információkat, a szolgáltatást emberi interakció nélkül, automatizált módon nyújtják. Ez az önkiszolgáló koncepcióhoz áll közel. Fizikai szolgáltatás esetében valamilyen emberi interakció is szükséges virtuális vagy pedig fizikai csatornán keresztül, tehát a folyamat nem automatizált. Az emberi intervenció a front office-ban, a back office-ban vagy mindkettőben történhet. Például egy online könyvesbolt esetében, amikor a potenciális vásárló egy könyvet keres, és segítségre van szüksége, az ügyfélszolgálathoz fordulhat telefonon vagy e-mailen keresztül. Ilyenkor egy fizikai szolgáltatást vesz igénybe az egyén egy virtuális csatornán keresztül. Amikor csak információt keres a honlapon vagy az ott található adatbázisban, akkor viszont virtuális szolgáltatást kap. Amikor postán megkapja a könyvet, akkor fizikai szolgáltatást vesz át fizikai csatornán keresztül.

Az e-kereskedelem vizsgálatát tovább bővíti, hogy a hagyományos boltok szerepe is jelentős a vásárlói döntési folyamatban. Sokan először megnézik a terméket, és utána az interneten megvásárolják, vagy az interneten gyüjtik az információt, és a végső döntés előtt offline is megnézik. Emiatt számos hibrid, vagyis online és offline felületeket is biztosító vállalat létezik, amellyel a sikert és növekedést kívánják biztosítani (Moon et al., 2011). Ilyenkor azonban nem szabad figyelmen kívül hagyni, hogy amennyiben egy fogyasztó az egyik csatornával elégedett, nem biztos, hogy a másikkal is az lesz; ehelyett az elégedettséget transzformálni kell az egyik csatornából a másikba, és vissza (Chen Cheng, 2012).

\subsection{Az elektronikus kereskedelem}

\subsubsection{Az elektronikus kereskedelem csoportosítása}

Az elektronikus kereskedelem definiálása több szempontból is történhet, így a szakirodalomban is többfajta megközelítéssel találkozhatunk. Chaffey (2006) véleménye szerint ez az üzleti tranzakciók minden olyan formáját jelöli, amely során a felek elektronikus úton érintkeznek, vagyis ide tartoznak az elektronikus üzleti akciók (Kápolnai - Nemeslaki - Pataki, 2002). Nemeslaki, Duma és Szántai (2004) megfogalmazásában az e-kereskedelem az a megoldás, ,, amikor a termék és a teljes 
folyamat digitalizálható és digitalizált”. Az a folyamat, melynek során semmilyen digitalizáció nem figyelhető meg, kiesik a körből (Nemeslaki et al. 2004, 41. old.). Drótos György és Móricz Péter (2000, 2001) vevőciklus modellje kilenc lépést tartalmaz, és véleményük szerint a korábbi definíciót felhasználva e-kereskedelemről akkor beszélhetünk, amikor ezek közül a folyamatok közül valamelyik digitalizált (6. ábra). E megközelítés alapján az elektronikus kereskedelem értelmezése nagy teret kap. Emiatt jelen munka során a következő, egyszerübb definíciót fogadjuk el: az e-kereskedelem egy üzleti lehetőség, melynek során a vállalat a fogyasztóival számítógépes hálózaton keresztül, elektronikus tranzakciókat használva hozza létre az üzletet (Liu - Arnett, 2000).

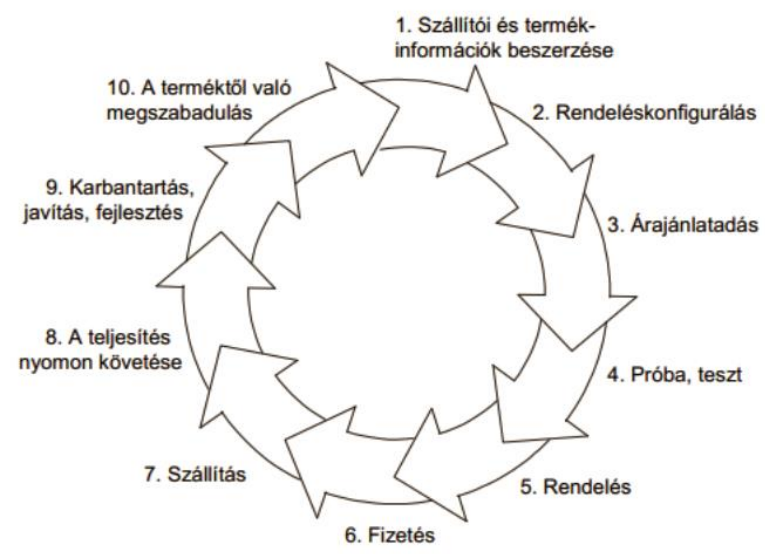

40. ábra. A vevő-eladó kapcsolat életciklus modellje (Drótos, 1999, 2001, Móricz, 2000)

\section{6. ábra: A vevő-eladó kapcsolat életciklus modellje}

Forrás: Móricz (2009)

Az e-kereskedelem három marketingfeladatot is felölel: az információnyújtást, az online eladást, vagyis amikor a rendelés és a vásárlás elektronikusan történik, valamint az eladás utáni szolgáltatásokat, problémakezeléseket (Liu - Arnett, 2000).

A szakirodalom alapján az elektronikus kereskedelem és e-business kapcsolatrendszerét kétféle módon lehet megközelíteni. Vannak, akik a két elnevezést egymás szinonimájaként használják (Kolos - Gáti, 2012). Ebben az esetben az interneten alapuló technológiák használatát értik alatta, amelyek összekötik a vevőket, beszállítókat, üzleti partnereket és a vállalati alkalmazottakat a termékeik és szolgáltatásaik vevői értékének növelése céljából. Ezzel szemben számos szerző szerint az e-kerekdelem az e-business gyűjtőernyője alá tartozik, amely fogalom a vállalat üzleti aktivitásának folyamatos 
optimalizálást jelenti a digitális technológia segítségével (Eszes - Bányai, 2002; Talyigás - Mojzes, 2004; Chaffey, 2006). Tehát az e-business túlmutat az e-kereskedelmen, mivel ez az üzleti funkciókat, vagy a teljes vállalati müködés online koncepcióit integrálja (Nemeslaki et al., 2004). A munkánk során az utóbbi megkülönböztető felfogást követjük. Annak függvényében, hogy a tranzakcióban az elosztói, illetve a fogyasztói oldalon kik vesznek részt - fogyasztó $(C)$, vállalat $(B)$, kormány $(G)$-, kilenc szegmense különíthető el az e-businessnek (2. táblázat).

\begin{tabular}{|c|c|c|c|c|}
\hline & & \multicolumn{3}{|c|}{ ELOSZTÓ } \\
\hline & & Fogyasztó (C) & Vállalat (B) & Kormány (G) \\
\hline \multirow{3}{*}{$\begin{array}{l}0 \\
\frac{0}{2} \\
\frac{1}{2} \\
0 \\
0 \\
0\end{array}$} & 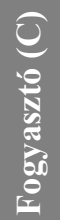 & $\begin{array}{c}\text { Eladás: pl. www.vatera.hu } \\
\text { Vélemény: } \\
\text { http://homar.blog.hu/ } \\
\text { Peer-to-peer: Skype } \\
\text { Közösségek, chat }\end{array}$ & $\begin{array}{c}\text { Eladás: } \\
\text { pl. www.bookline.hu } \\
\text { márkaépítés: pl. } \\
\text { www.unilever.hu }\end{array}$ & E-ügyintézés \\
\hline & 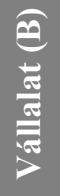 & $\begin{array}{c}\text { Árkialakítás } \\
\text { Fogyasztói visszajelzés }\end{array}$ & $\begin{array}{l}\text { Értékesítés } \\
\text { Piacterek } \\
\text { E-business }\end{array}$ & $\begin{array}{c}\text { E-ügyintézés } \\
\text { Visszajelzés a kormány } \\
\text { különböző szerveinek }\end{array}$ \\
\hline & 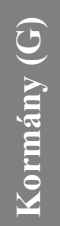 & $\begin{array}{c}\text { Visszajelzés a különböző } \\
\text { oldalakon }(+, \text { ill. - })\end{array}$ & $\begin{array}{c}\text { E-ügyintézés } \\
\text { Visszajelzés a kormány } \\
\text { különböző szerveinek }\end{array}$ & $\begin{array}{l}\text { Elektronikus } \\
\text { államigazgatás }\end{array}$ \\
\hline
\end{tabular}

\section{2. táblázat: Az e-business kategóriái}

Forrás: Chaffey et al. (2006), Nemeslaki et al. (2004): Az e-kereskedelmi ABC (42. old.)

A kategóriák többsége az e-kereskedelem területén is releváns, annak függvényében, hogy ki az eladó, illetve a vevő. A dolgozat során csak azokkal a webshopokkal kívánunk foglalkozni, amelyek esetében a vásárlói oldalon a lakossági fogyasztók, nem pedig a vállalatok vagy a kormány állnak.

$\mathrm{Az}$ online kereskedelem legelterjedtebb formája a B2C vonal, amikor a vállalatok értékesítenek a fogyasztóknak (Nemeslaki et al., 2004). Ezeket elektronikus kiskereskedőknek nevezzük (e-tailer), és ide tartoznak a virtuális kereskedők (pl. pelikan.hu), a többcsatornás, hibrid kereskedők (pl. alexandra.hu), a katalóguskereskedők (pl. LLBean.com), illetve a közvetlen elöállítók (pl. istyle.com).

Magyarországon Andrási (2011) összefoglalása alapján a következő online kiskereskedelmi piacok különíthetőek el: 
6. Kosaras rendszerben értékesitő webáruházak a hagyományos webshopok, melyek növekedése az elmúlt években kiemelkedően alakult, és az előrejelzések további növekedést prognosztizálnak (Enet, 2012).

7. Online aukciós piacterek esetében nem az eladó keresi a vevőt, hanem a vásárló keresi a terméket, és nem alkudozik, hanem licitál rá. A modell térnyerése világszerte és hazánkban is jellemző.

8. Ár-összehasonlitó oldalak segítenek abban, hogy a vásárlók a lehető legjobb ajánlatot tudják az interneten megtalálni, melyekhez a webshopoknak külön kell csatlakozni. Igaz, közvetlen vásárlásra itt nincs lehetőség, de a kattintások, illetve vásárlások után kapnak jutalékot a közvetítésért.

9. Az online apróhirdetések között hazánkban a B2C vonalon az autókereskedők és az ingatlanosok ajánlatai a legjelentősebbek.

10. Turisztikai szolgáltatások tekintetében elmondható, hogy a legtöbb szálláshely, utazási iroda rendelkezik online elérhetőséggel, és a többség online foglalási lehetőséget is kínál.

11. A kultúra és szórakozás fogyasztása, illetve a jegyértékesítés különböző rendezvényekre kiemelt szereppel bír az e-kereskedelem területén.

12. Pénzügyi és biztositási ügyleteket kínáló webshopok esetében a vásárlóknak lehetőségük van biztosításuk, pénzügyi tranzakciók online intézésére.

13. Az online játék és szerencsejáték hazánkban is egy kedvelt online időtöltési lehetőség, és több százezres a havi előfizetők aránya is (Andrási, 2011, 103. old).

14. Egyéb: felnőtt tartalmak, illegális letöltő oldalak.

Napjainkban az ún. C2C online kereskedelem térnyerése is jelentős, melynek során a fogyasztók egymás között üzletelnek (Nemeslaki et al., 2004; Andrási, 2011). Ebbe a csoportba tartoznak a különböző aukciós oldalak és a hirdető portálok. A G2C vonal az elektronikus kormányzathoz tartozó tranzakciókat foglalja magában.

Az e-kereskedelem csoportosítása az értékesített jószág (termék és/vagy szolgáltatás), illetve a teljesítés módja szerint (offline - elektronikus) is történhet. Adam (2002) szerint a vállalatok internetes használati szokásai a kereskedelem területén a tiszta (pure) offline és a tiszta (pure) online kontinuumban mozognak, melynek középpontját a ,clicks-andbricks” boltok adják. Mások az e-kereskedelem sajátosságait a szállítás módjában látják: szerintük célszerü eltérő fókusszal vizsgálni a postán vagy a futárral szállítókat, illetve 
azokat, akik elektronikusan szállítanak (Francis - White, 2002; Wolfinbarger - Gilly, 2003; Zeithaml et al., 2000).

Ez az online-offline csoportosítás egy jó marketing alapú megoldás, azonban továbbra sem fedi le a teljes e-kereskedelmet: egyik csoportba sem sorolhatóak be egyértelmúen azok a termékek/szolgáltatások, amelyeket kifizetnek és egyből online el is fogyasztanak a vásárlók. Ezt a gondolatmenetet felhasználva Francis és White (2003, 2004) megkülönbözteti az online/elektronikus, illetve az offline teljesítés kategóriáját. Online teljesítés esetében a vásárlónak a tranzakció után az elektronikus környezetben kell „maradnia”, hogy letöltse, vagy elfogyassza a terméket, míg offline esetben a megrendelés után elhagyhatja a virtuális világot. Az általuk megalkotott elektronikus kereskedelmi csoportosítás egyik dimenzióját ez adja. A megkülönböztetés másik tényezője, hogy kézzel fogható termékeket vagy nem megfogható szolgáltatásokat értékesít-e az online áruház. Ezek alapján egy $2 * 2$-es mátrix alakul ki négy kategóriával (Francis - White 2003, 2004): (1) offline-termékek, (2) offline-szolgáltatások, (3) elektronikus-termékek, és (4) elektronikus-szolgáltatások (7. ábra).

\begin{tabular}{|c|c|c|c|}
\hline & \multicolumn{2}{|c|}{ TELJESÍTÉS MÓDJA } \\
\hline & & Offline & Elektronikus \\
\hline \multirow{4}{*}{ 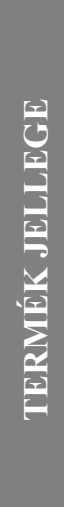 } & & Offiline-termékek & E-termékek \\
\hline & 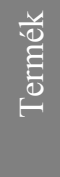 & $\begin{array}{l}\text { A vásárló online rendel, azonban } \\
\text { offline kapja meg a terméket } \\
\text { pl. könyv, mobiltelefon, bútor }\end{array}$ & $\begin{array}{l}\text { A vásárló fizetés után egyböl letölti } \\
\text { a terméket, és előkészíti a } \\
\text { fogyasztásra } \\
\text { pl. szoftverek, MP3, e-újságok }\end{array}$ \\
\hline & & Offlline-szolgáltatások & E-szolgáltatások \\
\hline & 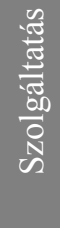 & $\begin{array}{c}\text { A rendelés online történik, de az } \\
\text { egyén offline kell, hogy eljusson a } \\
\text { szolgáltatóhoz } \\
\text { pl. utazás, szállás, belépőjegyek, } \\
\text { masszázs }\end{array}$ & $\begin{array}{l}\text { Egy felhasználói fiókot hoz létre az } \\
\text { egyén, mely szükséges ahhoz, hogy } \\
\text { elfogyaszthassa a fő szolgáltatást } \\
\text { pl. e-banking, chatszobák, } \\
\text { részvénykereskedés }\end{array}$ \\
\hline
\end{tabular}

7. ábra: Az e-kereskedelmi kategóriái a teljesítés módja és a termék jellege szerint

Forrás: Francis - White (2003, 2004)

Az offline-termék esetében a vásárló online rendel, azonban offline kapja meg a terméket (pl. könyv, mobiltelefon, bútor). Az offline-szolgáltatásoknál is a rendelés online történik, de az egyén offline kell, hogy eljusson a szolgáltatóhoz (pl. utazás, szállás, belépőjegyek, masszázs) vagy a szolgáltató az egyénhez. Ezen esetek többségében a késleltetett fizetés (pl. átvétel), valamint a későbbi termékcsere-folyamat a jellemző (Francis - White, 2004). 
Ezzel szemben az elektronikus-termékek esetében a vásárló fizetés után egyböl letölti a terméket, és előkészíti a fogyasztásra (pl. szoftverek, MP3, elektronikus újságok), míg az elektronikus-szolgáltatás vásárlásakor egy felhasználói fiókot hoz létre az egyén, mely szükséges ahhoz, hogy elfogyaszthassa a fő szolgáltatást (pl. e-banking, chatszobák, részvénykereskedés) (Francis - White, 2002, 2003, 2004; Francis 2007).

\begin{tabular}{|c|c|c|c|c|c|c|c|c|c|}
\hline & 2005 & 2006 & 2007 & 2008 & 2009 & 2010 & 2011 & 2012 & Kategória \\
\hline Könyv, magazin & 37 & 40 & 43 & 42 & 42 & 45 & 45 & 44 & Offline-termék \\
\hline Ruha, sporteszköz & 15 & 20 & 19 & 24 & 30 & 31 & 36 & 40 & Offline-termék \\
\hline Szállás & 21 & 24 & 23 & 21 & 28 & 31 & 33 & 36 & Offline-szolgáltatás \\
\hline Belépó & 20 & 25 & 28 & 25 & 23 & 27 & 27 & 30 & Offline-szolgáltatás \\
\hline Háztartási eszköz & 9 & 11 & 10 & 11 & 15 & 21 & 22 & 27 & Offline-termék \\
\hline Film, zene & 20 & 19 & 21 & 13 & 17 & 18 & 17 & 14 & Offline-termék \\
\hline $\begin{array}{l}\text { Telekommunikációs } \\
\text { szolg. }\end{array}$ & n.a & n.a & n.a & n.a & 11 & 11 & 15 & 15 & Offline-szolgáltatás \\
\hline Elektronikai termék & 11 & 13 & 14 & 13 & 15 & 14 & 15 & 14 & Offline-termék \\
\hline Software & 17 & 17 & 14 & 10 & 15 & 16 & 14 & 14 & Offline-szolgáltatás \\
\hline Könyv, magazin online & 25 & 23 & 20 & 17 & 10 & 11 & 13 & n.a. & Elektronikus-termék \\
\hline Szerencsejáték & n.a & n.a & n.a & n.a & 15 & 12 & 13 & n.a & Elektronikus-szolg. \\
\hline $\begin{array}{l}\text { Film, zene ONLINE } \\
\text { használatra, vagy } \\
\text { frissítésre }\end{array}$ & 13 & 12 & 10 & 6 & 9 & 9 & 10 & n.a & Elektronikus-termék \\
\hline Hardware & 10 & 10 & 11 & 9 & 10 & 11 & 10 & 9 & Offline-termék \\
\hline $\begin{array}{l}\text { Software ONLINE } \\
\text { használatra vagy } \\
\text { frissítésre }\end{array}$ & 13 & 11 & 8 & 5 & 7 & 9 & 8 & n.a. & $\begin{array}{l}\text { Elektronikus- } \\
\text { szolgáltatás }\end{array}$ \\
\hline Étel & 7 & 5 & 9 & 5 & 6 & 7 & 7 & 8 & Offline-termék \\
\hline $\begin{array}{l}\text { Videojáték ONLINE } \\
\text { használatra vagy } \\
\text { frissítésre }\end{array}$ & n.a & n.a & n.a & n.a & 7 & 8 & 7 & 8 & Elektronikus-termék \\
\hline Gyógyszer & n.a & n.a & n.a & n.a & 4 & 6 & 6 & 8 & Offline-termék \\
\hline Pénzïgyi szolg. & 5 & 4 & 5 & 4 & 4 & 4 & 6 & 6 & Offline-termék \\
\hline Egyéb & 22 & 23 & 26 & 26 & 26 & 26 & 22 & 20 & \\
\hline
\end{tabular}

\section{3. táblázat: A Magyarországon online vásárolt termékek és szolgáltatások köre, több válasz lehetősége}

\section{$N=a z$ elmúlt egy év során online vásárlók}

Forrás: Eurostat (2013)

Az Eurostat (2013) adatai szerint Magyarországon 2012-ben az elmúlt egy évben online vásárlók körében a többség könyveket, magazinokat (44\%), ruhákat és sporteszközöket (40\%), illetve szállást vásárolt (36\%). Ezek mind az offline-termékek és -szolgáltatások körébe tartoznak. Az elektronikus-termékek és -szolgáltatások közül a legtöbben ekönyvet és e-magazint vettek (elektronikus-termék), valamint szerencsejátékkal foglalkoztak (fogadás, lottó, gambling) regisztrált fiókjukban (elektronikus-szolgáltatás). Az eredmények alapján megállapítható, hogy hazánkban egyelőre az interneten leginkább offline-termékeket és -szolgáltatásokat vásárolnak (3. táblázat). 


\subsubsection{A vásárlói döntés folyamata}

Az elektronikus szolgáltatásminőség definíciója kimondja, hogy a fogyasztói értékelés a vásárlás egész szakaszára kiterjed, ezért is érdemes a vásárlói döntési szakaszokat részleteiben megismernünk. A későbbiekben a bemutatott elektronikus szolgáltatásminőség koncepciókat is az alapján értékeljük, hogy milyen szinten fedik le ennek a folyamatnak a lépéseit (8. ábra).

A vásárlási döntési folyamat az igazi, „kiterjesztett” vásárlások esetében öt lépésből áll, mely folyamat a vásárlás, illetve a döntési szituáció jellegétől függően (kis értékü, alacsony involvementü termékek) lerövidülhet (Hofmeister-Tóth, 2008).

Az első lépés a problémafelismerés szakasza, amely az igény, a szükséglet felmerülését jelenti, és különböző szituációs tényezők (pl. elégedetlenség a meglévő termékkel, változatosságkeresés, készlet elfogyása, vállalati marketingtevékenység) befolyásolják. Az elektronikus kereskedelem esetében ez az online vásárlás iránti igény felmerülését jelenti, mely igény vonatkozhat termékekre, valamint szolgáltatásokra egyaránt.

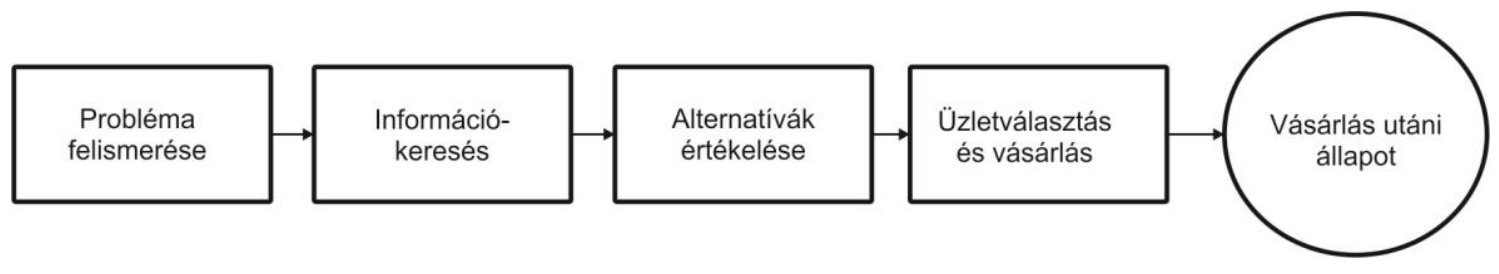

\section{8. ábra: A vásárlási döntés szakaszai}

Forrás: Hofmeister-Tóth (2008), 219. old.

A következő szakasz során az egyén információgyüjtési folyamatba kezd, amikor is aktívan és/vagy passzívan, külső és/vagy belső forrásokat felhasználva keresi meg a releváns információkat. Ebben a szakaszban van jelentősége a szájreklámnak is, mely irányától függően - pozitív vagy negatív szájreklám - a vállalati kommunikációt erősíti vagy gyengíti.

A webshopok számos információt, összehasonlítási lehetőséget biztosítanak a látogatóik számára (árak, kiszállítás feltételei, fizetési lehetőségek, támogatások, referenciák stb.), illetve a különböző (saját vagy külső) fórumokon és blogokon megjelenő információk is hatással bírnak a vásárlói döntésre. Ebben a szakaszban a korábbi használat vagy vásárlás során kialakult vélemények (pl. elégedettség) - ezeket nevezzük belső információknak is jelentősek. 
A megfelelő mennyiségü információ összegyüjtése után - ezt az egyén információgyűjtési hajlandósága, illetve a vásárlás fontossága is befolyásolja - az alternatívák értékelésének szakaszában hozza meg a potenciális vásárló a döntését. A tranzakció befejeztével azonban még nem ér véget a vásárlási folyamat, ugyanis ezután dől el, hogy a vásárló megfelelő döntést hozott-e, az elvárt minőséget teljesíti-e az adott termék/szolgáltatás, és ez alapján alakul ki az elégedettség vagy elégedetlenség.

Az internetes vásárlói hajlandóságot számos tényező befolyásolja. A személyes jellemzők közül a technológiához való hozzáállás, a „hálózati” életstílus, az online töltött idő, az internethasználati tapasztalat, a technológiai felkészültség, valamint az optimizmus a legjelentősebbek (Bellman et al., 1999; Modahl, 2000; Novak - Hoffman, 2000; Parasuraman, 2000; Wolfinbarger - Gilly, 2002). Demográfiai jellemzők tekintetében az online vásárlók magasabb jövedelemmel rendelkeznek, karrierorientáltak, emellett kényelemorientáció és időspórolási vágy jellemzi őket (Lohse - Bellman, 2000; Parasuraman 2000; Wolfinbarger - Gilly, 2002). A fogyasztókhoz kapcsolódó szokások mellett azonban nem szabad figyelmen kívül hagyni az ún. szituációs hatásokat sem, vagyis azt, hogy milyen termékről/szolgáltatásról beszélünk, milyen a vásárló hangulata, és hogy tervszerü, célirányos vásárlást tervez-e, vagy inkább a hedonista értékek játszanak fontos szerepet (Wolfinbarger - Gilly, 2002).

A fentebb bemutatott folyamat leírása is mutatja, hogy a döntési szituációt befolyásolja a korábbi tranzakció során kialakult elégedettség. Ezért tartjuk fontosnak megvizsgálni, hogy az különböző minőségdimenziók értékelése az elégedettségen át hogyan befolyásolja az újravásárlást, illetve a szájreklámot, mely más fogyasztók információgyüjtési szakaszában jelenthet támogatást egy webshop kiválasztása során.

\subsubsection{A vásárlási folyamat az elektronikus kereskedelem esetében}

Bauer és társainak (2006) véleménye alapján az elektronikus kereskedelem négy lépése különíthető el. Az első lépésben az ajánlatokat vizsgálják és hasonlítják össze az egyének, ezután tárgyalnak, és jobb esetben megkötnek egy szerződést. Ezek inkább az információgyüjtésről szólnak, a tényleges csere a harmadik szakaszban történik, a negyedik pedig a kapcsolattartási tevékenységeket tartalmazza (Bauer et al., 2006). Véleményük szerint az első lépésben, vagyis az információkeresés szakaszában az ár, a hírnév, a rendelési-szállítási határidő stb. jelentősek. Mivel online környezetben több lehetőség van a keresésre és az összehasonlításra, mint offline környezetben, ezért a minőség szempontjából az a lényeges, hogy a honlap milyen külső és belső értékeket 
nyújt (Childers et al., 2001). A használat egyszerüsége, a navigáció játékossága, a használhatóság foka, a termékek bemutatása, az észlelt élvezet a honlap használata kapcsán, valamint a személyre szabott tartalom lehet befolyásoló és jelentős ebben a szakaszban (Zeithaml et al., 2002).

A második lépés során, amikor megegyeznek a részletekröl, a vásárlók közötti kommunikáció, valamint az eladóval folytatott interakciók támogatása, például e-mail, fax, chat, fórum a jelentősek (Barnes - Vidgen, 2001; Jayawardhena, 2004).

A teljesítés szakaszában a rendelés leadásának egyszerüsége befolyásol (Parasuraman et al., 2005; Wolfinbarger - Gilly, 2003), és a rendelési felület/honlap az összeomlást, valamint a hibákat kell kerülni. További jelentős tényező az azonnali visszajelzés, a szállítási visszaigazolás, valamint a megfelelő, megígért módon és időben történő szállítás (Meuter et al., 2000). Az utolsó szakaszban a fogyasztóval való törődés játszik jelentős szerepet, vagyis a kérdésekre és problémákra adott azonnali válaszok (Parasuraman et al., 2005). Ez utóbbi terület már a panaszkezelés témakörébe tartozik, melynek során a vevő kompenzálása történik a hiba elismerésével, bocsánatkéréssel, vagy bármilyen egyéb formális procedúra során (Kenesei - Kolos, 2008).

Az elektronikus kereskedelem esetében a teljes vásárlási folyamat eltérően alakulhat annak függvényében, hogy a Francis és White (2003) által megalkotott négy terület közül melyikről beszélünk, vagyis az offline-termékek vagy szolgáltatások, e-termékek, vagy szolgáltatások vásárlásának esetét vizsgáljuk. Ezeknek a különbségeknek a tisztázása azért fontos, hogy az elektronikus szolgáltatásminőség dimenziót a jövőben a lehető legpontosabban tudjuk meghatározni.

Függetlenül attól, hogy melyik területről beszélünk, a döntés előtti információkeresés kiemelt szereppel bír, vagyis az, hogy a kívánt információk a webshop honlapján hogyan érhetők el. A szükséges információk összegyüjtése, értékelése és a döntés megszületése után veszi kezdetét a vásárlási tranzakció lebonyolítása, ami magában foglalja a kiválasztott termék vagy szolgáltatás megjelölését, a „kosárban történő elhelyezését”, a szükséges adatok bevitelét, majd a pénzügyi teljesítést, mely történhet kártyával, átutalással vagy offline teljesítés esetében az átvételkor, készpénzben. Látszólag az információgyüjtés és a tranzakció lebonyolítása hasonlóan alakul a négy kategóriában. A későbbiekben a szakirodalom alapján is megvizsgáljuk, hogy az ide tartozó minőségdimenziók esetében megfigyelhető-e eltérés. 
A megvásárolt termék, illetve szolgáltatás átvételének módjában már jelentős különbségek adód(hat)nak. Offline-termékek esetében lehetőség van a kiszállításra (posta, futár stb.) vagy egy felvevőponton való átvételre. Offline--szolgáltatásoknál az igénybevételre jogosító utalványt vagy jegyet elektronikus (pl. e-mailben) vagy postai úton tudja az eladó a vásárlóhoz eljuttatni, és ennek az igazolásnak a birtokában lehetséges a vásárolt szolgáltatást igénybe venni (pl. színház, masszázs, utazás). Az elektronikus-termékek elfogyasztásakor azonban az egyén a gép előtt marad, és onnan tudja letölteni azt (pl. zene, software), míg az elektronikus-szolgáltatások esetében valamilyen regisztrált fiókon keresztül lehetséges a szolgáltatás igénybevétele (pl. online átutalás, biztosításkötés, játék).

Bármelyik esetet vegyük is, a tranzakció közben vagy után fellépő problémák, kérdések kezelése is az elektronikus szolgáltatásminőség dimenziójába tartozik, ezért a minőségkoncepciók értékelésekor ezt is figyelembe kell venni.

\subsection{Az elektronikus szolgáltatásminőség mérésére szolgáló skálák}

A honlapok és webshopok által nyújtott minőségkoncepciók megalkotásának hulláma a 2000-es évek elején vette kezdetét, és még napjainkban is születnek újabb és modernebb megközelítések. A kezdetben megalkotott koncepciók jelentős része korlátozott volt, mivel többségük mindössze a site-on történő vagy csupán az utólagos interakció(k)ra koncentrált. Mint ahogy azt korábban bemutattuk, a webáruházakhoz kapcsolódó elektronikus szolgáltatásminőség a teljes vásárlási folyamat értékelését magában foglalja, ezért a hiányos megközelítéseket a 2000-es évek közepén számos kritika érte (Wolfinbarger - Gilly, 2003; Parasuraman et al., 2005; Bauer et al., 2006). További általános kritika a létrehozott skálákkal kapcsolatban, hogy minden honlapot (a szórakoztató honlapoktól az e-shopokig) egy kalap alatt igyekeztek vizsgálni, pedig a site célja jelentősen befolyásolhatja a minőségdimenziók alakulását (Wolfinbarger - Gilly, 2003), emellett az elektronikus kereskedelem folyamatát is érdemes az alapján külön kezelni, hogy terméket vagy szoláltatást értékesítenek-e (Srinivasan et al., 2002; Francis, 2007; Sejin - Leslie, 2012).

A következőkben a teljesség igénye nélkül mutatjuk be az elektronikus szolgáltatásminőség mérésére szolgáló skálák fejlődését napjainkig. Az összefoglalás célja, hogy feltérképezze az elektronikus szolgáltatásminőség dimenzióit, illetve kapcsolatukat az elégedettséggel és annak következményeivel. 


\subsubsection{A legelső próbálkozások az elektronikus szolgáltatásminőség területén}

Az online vásárlók viselkedését eleinte a különböző vállalatok is tanulmányozták, azonban közülük senki sem konceptualizálta megfelelően a fogalmat, és a mérések validitása, valamint megbízhatósága sem került tesztelésre a létrehozott skálák esetében.

A Bizrate.com üzleti skálája egy használat utáni értékelés, mely az erősségeket és gyengeségeket emeli ki. A következő tényezőket vizsgálták a kutatás során: (1) a rendelés egyszerüsége, (2) termékválaszték, (3) termékinformáció, (4) ár, (5) websiteteljesítmény, (6) időben történő szállítás, (7) termékbemutatás, (8) fogyasztók támogatása (support), (9) adatvédelem, (10) postázás, szállítás. Eredményeik alapján a visszalátogatás szempontjából legfontosabb a támogatás, legkevésbé pedig az ár (Zeithaml et al., 2002; Wolfinbarger - Gilly, 2002).

Egy másik üzleti modell a Gomez.com, mely a minőséget a teljesítményadatok alapján méri. Kategóriái a következők: (1) használat egyszerüsége, (2) az információk hatékony elérése, (3) fogyasztói bizalom, (4) megbízhatóság, (5) mióta működik a cég, (6) a site erőforrásai, (7) kapcsolati szolgáltatások és (8) teljes költség (Wolfinbarger - Gilly, 2002).

Ezzel szemben a CIO.com mindössze négy területtel foglalkozott, amelyek: (1) az észlelt problémák a rendelés során, (2) észlelt problémák a rendelés után, (3) vevőszolgálat, cég elérhetősége a rendelés során, (4) vevőszolgálat, cég elérhetősége a rendelés után (Zeithaml et al., 2002).

Az akadémiai életben az első jelentős koncepció Rice (1997) nevéhez füződik. Szerinte egy honlap újralátogatásához a legfontosabb kritérium a dizájn, a tartalom, az egyszerü keresés és navigáció, valamint az érzelmi élmény (Zeithaml et al., 2002). Rust és Lemon (2001) szerint az elektronikus szolgáltatásminőség felsőbbrendű élménynyújtás a fogyasztóknak az interaktív információáramlást (FLOW) követve.

Szymanski és Hise (2000) megfogalmazásában az elektronikus minőségészleléshez, és ezen keresztül az elégedettséghez négy faktor járul hozzá: (1) a kényelmességről alkotott percepció, (2) az áruválaszték (termékkínálat és -információ), (3) a site designja és (4) a pénzügyi biztonság. A kérdések megalkotásakor azonban az offline boltokat hasonlították össze az online-okkal. 
Novak és társainak (2000) kutatása arra kereste a választ, hogy melyek azok a tényezők, amelyek az online élményt elősegítik. A vizsgált kritériumok a következők: (1) kapcsolatba lépés egyszerüsége, (2) fizetési visszatérítés, (3) törlés egyszerűsége, (4) ügyféltámogatás, (5) változatosság, (6) az információ minősége, (7) megbízhatóság, (8) biztonság, (9) alacsony ár (Wolfinbarger - Gilly, 2003).

A NetOffer modell szerint az e-szolgáltatásminőség funkcionális (mit kapnak a szolgáltatás outcome-jaként) és technikai (hogyan történik a folyamat) dimenziókra bontható (Grönroos et al., 2000; Bauer et al., 2006).

Yang, Peterson és Huang (2001) online gyógyszertárak esetében vizsgálták az észlelt szolgáltatásminőség elemeit. Kutatásuk során a következő faktorokat azonosították: (1) a használat egyszerüsége - felhasználóbarát felület, egyszerü keresés, gyors honlap, (2) a megosztott információ minősége, frissessége, kapcsolódása a tartalomhoz, (3) az információ hitelessége, (4) a válaszadás ideje, (5) esztétika, illetve (6) személyes adatok védelme (Yang et al., 2001). A kialakított dimenziók azonban önkényesek, és empirikusan nem tesztelt kategóriák (Parasuraman et al., 2002).

\subsubsection{Liu és Arnett (2000)}

Az elektronikus szolgáltatásminőség szakirodalmában az első jelentős skála kifejlesztése Liu és Arnett (2000) nevéhez füződik. Kutatásuk célja az volt, hogy megismerjék a sikeres honlap dimenziót. Az információs rendszerek szakirodalmában a siker annak a függvénye, hogy egy rendszer milyen szinten képes azt a célt ellátni, amiért létrehozták (Durry - Farhoomand, 1996).

Kutatásuk során a Fortun 1000 cégek webmestereit kérdezték meg azokról a faktorokról, amelyek véleményük szerint fontosak a fogyasztóknak egy sikeres honlap esetében. 119 interjú után 4 dimenzióba sorolva határozták meg a legfontosabb területeket, úgymint (1) az információ és a szolgáltatások minősége, a gyors válasz, az empátia, garancia, utánkövetés; (2) a biztonság, korrekt tranzakciók, a személyes adatok védelme; (3) a játékosság, interaktivitás, élvezet, valamint a (4) design (Liu - Arnett, 2000). Ezeknek a fejlesztésére és legjobb megvalósítására kell törekedni a siker érdekében. Kutatási koncepciójukban a szakirodalom alapján további két faktort is megneveztek, mint lehetséges sikertényezőt (tanulási képesség, ill. rendszerhasználat), azonban az eredményeik alapján ezek nem bizonyultak relevánsnak. 
A kutatás korlátai között említhető, hogy nem a fogyasztókat, hanem a készítőket, a webmestereket kérdezték meg (Zeithaml et al., 2002; Wolfinbarger - Gilly, 2003), valamint a mintavételi keret miatt a megállapítások inkább a nagyvállalatokra vonatkoznak, és nem biztos, hogy általánosíthatóak (Liu - Arnett, 2000).

\subsubsection{WebQual ${ }^{\mathrm{TM}}(2000,2002,2007)$}

Loiacono, Watson és Goodhue (2000, 2002, 2007) többlépcsős kutatásának fő célja, hogy megvizsgálják, melyek azok az észlelt jellemzők, amelyek egy honlap újra-használatához vezetnek. A számítástechnikai technológiák alkalmazása során a használat egyszerüsége, illetve az észlelt hasznosság (Loiacono et al., 2007) befolyásolják leginkább az újrahasználati szándékot, azonban véleményük szerint a honlapok esetében ez a két dimenzió nem magyarázza teljesen a folyamatot, ezért célszerü a problémával részleteiben foglalkozni. Az elemzéshez CD-t, könyvet, repülőjegyet értékesítő, illetve hotelfoglalásokkal foglalkozó honlapokat vizsgáltak.

Kutatásuk során interjúkat készítettek fogyasztókkal, designerekkel, és négy alkalommal (2000 tavasz, ősz, 2002, 2007) tanulókat kértek, hogy értékeljenek bizonyos honlapokat. Eredményeik alapján 11 releváns dimenziót fogalmaztak meg 36 mérési tétellel/indikátorral (Loiacono et al., 2007), amelyek hat nagy területet fednek le:

1. Észlelt hasznosság:

a. az információ illeszkedése - információk alkalmassága, minősége, bemutatása;

b. interakció - kommunikáció, interaktív információkeresés, tranzakciók lebonyolítsa;

c. teljes online szolgáltatás;

d. relatív hasznosság.

2. Használat egyszerüsége:

a. intuitív kezelési felület, egyszerű használat;

b. design, megértés egyszerüsége.

3. Bizalom-adatvédelem

4. Válaszadási idő

5. Szórakozás:

a. vizuális megjelenítés;

b. innovativitás - AHA érzés,

6. Érzelmi befolyás, konzisztens imázs 
A WebQual ${ }^{\mathrm{TM}}$ minden egyes dimenziója megfelelő diszkrimináns érvényességgel bír, és pozitív kapcsolatban áll a vásárlási és újralátogatási szándékkal. A kutatás során a hasznosság, a használat egyszerűsége és a szórakozás dimenziói mellett a bizalom és a válaszadási idő fontosságát tárták fel.

A megalkotott skálát számos kritika érte. Az utólagos elemek értékelésére nem volt lehetőség, mivel a kutatásban résztvevőknek olyan honlapokat kellett értékelni, ahol még nem hajtottak végre tranzakciót (Loiacono et al., 2007), emellett többek szerint a feltárt dimenziók mindössze a technikai minőségre koncentrálnak (Zeithaml et al., 2002; Bauer et al., 2006). Parasuraman és társainak kritikája (2005), hogy a megnevezett dimenzióknak csak egy része befolyásolja az elégedettséget, a többi, mint például az innovativitás vagy helyettesíthetőség csak érintik azt, illetve ez a módszer inkább a webfejlesztőknek nyújt segítséget, mintsem a minőség és ez által az elégedettség mérését segítse. Úgy gondolom, hogy további kritikaként a skála hossza is megemlíthető (12 dimenzió 36 indikátorral).

\subsubsection{WebQual 1.0 - $4.0(2001,2002)$}

Barnes és Vidgen fő célja a WebQual skála fejlesztés során (2001-2004) egy kiváló honlap jellemzőinek megismerése volt. A végeredmény egy online kérdőív, mely egy hétfokú skálán méri a fogyasztó észlelését a honlap minőségével kapcsolatban, illetve azt, hogy az adott tényező mennyire fontos. A skálát 1998 óta fejlesztik, és számos módosításon ment keresztül.

A WebQual 1.0 négy dimenzió mentén mérte a minőséget (Barnes - Vidgen, 2000):

1. Használat egyszerüsége: egyszerü, intuitív, konzisztens navigáció, a fogyasztók képesek legyenek körbenézni a honlapon, megtalálni a dolgokat.

2. Tapasztalat/élmény: a honlap vizuális megjelenése, design, színek, stílus és a személyes élmény.

3. Információ: jó minőségü tartalom, amely könnyen olvasható, érthető, releváns, megbízható, megfelelően részletezett és formázott.

4. Kommunikációs és integráció: milyen módon integrált a külső környezetbe, más honlapokkal összekötő linkek, biztonságos kommunikáció, gyorsaság.

Igaz, hogy a kutatás során kicsi hallgatói mintát használtak (81 fö), de az elsődleges célnak, vagyis hogy az egyetemi honlapokat rangsorolni tudják, ez megfelelt. A skálával 
szemben megfogalmazott kritikák szerint az mindössze az információ minőségéről szólt, és inkább a vállalati oldalt képviselte, mintsem a fogyasztóit, valamint hiányzott belöle az interakciós perspektíva is. Az irodalom, illetve a SERVQUAL alapján a WebQual 2.0 esetében az interakciót is belevették a modellbe, azonban az előző változathoz képest ez veszített az információra vonatkozó minőségkritériumokból. A továbbfejlesztett WebQual 3.0 már három fó dimenziót tartalmazott: (1) honlapminőség, (2) információminőség, illetve (3) a szolgáltatási interakció minősége.

Az ajánlások és kritikák alapján ezt továbbfejlesztve született meg a mai is használatos WebQual 4.0 (Barnes - Vidgen, 2002, 2003, 2004). Ebben négy fö kategória szerepel:

1. Használhatóság (8 mérési tétel): a honlap egyszerü használathatósága, illetve dizájnja.

2. Információ minősége (7 mérési tétel): az ott található információk minősége, mint például hihetőség, frissesség, relevancia stb.

3. Interakció minősége (7 mérési tétel): az interakciós lehetőségek minősége, illetve gyorsasága, az információk biztonsága.

4. Teljes összbenyomás a honlapról (1 mérési tétel).

Bauer és szerzőtársainak kritikája szerint (2006) a WebQual változatai jellemzően a technikai megoldásokra koncentrálnak (pl. használat egyszerüsége), így inkább tervezési segédletként szolgálnak, míg Francis és White (2002) a WebQual 4.0 megalkotásának folyamatát bírálta, mivel a kutatásban résztvevőknek úgy kellett értékelniük a honlapokat, hogy nem volt kötelező vásárolniuk, vagy kommunikálniuk a site-tal.

\subsubsection{SITEQUAL (2001)}

A SITEQUAL skálát az észlelt minőség mérésére alkották meg, és a kutatás során a szerzők azt is megvizsgálták, hogy a skála dimenziói minként hatnak a vásárlási viselkedésre, úgymint a keresési sémákra és a vásárlási döntésre (Yoo - Donthu, 2001).

A kutatás során hallgatókat kérdeztek meg, mivel véleményük szerint ők a legaktívabb internetes vásárlók, emellett a technológiában jártasak, és az innovativitásra nyitottak. Az irodalom alapján az internettel kapcsolatos minőség esetében a következő dimenziókat azonosították kutatásuk megkezdésekor:

1. szórakoztatás, információnyújtás, szervezettség; 
2. érzéki benyomás, választék, összetevők, egyszerüség, mentések, szolgáltatás, biztonság;

3. megjelenés, tartalom, linkek, használat, struktúra, speciális jellemzők;

4. információk, letöltési sebesség, elérhetőség, használat egyszerüsége, hatékony tranzakciók;

5. hedonista és haszonelvü értékek;

6. társadalmi elfogadottság, szocializáció, információ, interaktív kontrol, gazdasági értékek, biztonság, adatvédelem.

A kutatás eredményeként kialakított SITEQUAL skála végül négy faktort tartalmazott, úgymint:

1. A használat egyszerüsége (2 mérési tétel): milyen könnyü az információt megtalálni, illetve kényelmes-e a honlap használata.

2. Esztétikai design (3 mérési tétel): kreativitás, színesség, képek a termékekről.

3. Feldolgozás sebessége (2 mérési tétel): gyorsan, hatékonyan müködő folyamatok a honlapon.

4. Biztonság (2 mérési tétel): adatok biztonságának érzete.

A SITEQUAL képes a minőséget mérni, valamint a menedzserek számára egy indexet biztosít, amelyet felhasználhatnak honlapjuk teljesítményének javításához. Yoo és Donthu (2001) eredményei alapján megállapítható, hogy minél többet vásárol valaki az interneten, annál inkább kritikusabbá válik.

A szerzők véleménye szerint a SITEQUAL-t nem mint egy végleges skálát kell értelmezni, inkább egy jobb mérési megoldás kiindulópontjaként szolgál (Yoo - Donthu, 2001). A skálával kapcsolatban később kritikaként fogalmazták meg, hogy hasonlóan a WebQual 1.0-hoz, ez sem tér ki a vásárlás minden dimenziójára (pl. ügyfélszolgálat, szállítás), tehát nem is értelmezhető átfogó skálaként, és valóban szükséges a továbbfejlesztése (Wolfinbarger - Gilly, 2003; Parasuraman et al., 2005; Bauer et al., 2006).

\subsubsection{PIRQUAL (2002)}

Francis és White 2002-ben 14 fókuszcsoport alapján alakította ki a PIRQUAL (perceived internet retailing quality) skála alapját, melyet 302 ausztrál online vásárló általi kitöltése után véglegesítettek. 
A PIRQUAL 6 dimenzió mentén méri az észlelt internetes értékesítői minőséget:

1. Honlap funkcionalitása,

2. Termékjellemzők leírása,

3. Tranzakciós rendszer (pl. e-mail visszaigazolás a megrendelésröl, végösszeg egyszerü kalkulációja szállítási feltételekkel),

4. Szállítás (megfelelö termék, megfelelő rendelési megoldás),

5. Ügyfélszolgálat,

6. Biztonság.

Az elektronikus szolgáltatásminőség szakirodalmában ez az első skála, melynek megalkotásakor a diszkonfirmációs paradigmát felhasználták, vagyis az észlelt minőséget az elvárások és a teljesítmény alapján kalkulálták (Francis - White, 2002):

PIRQUAL $=\mathrm{P}($ erceived $/$ észlelt teljesítmény $)-\mathrm{E}($ xpected $/$ elvárt teljesítmény $)$

Wolfinbarger és Gilly (2003) kritikája szerint a skála megalkotásakor inkább a viselkedési szándékra koncentráltak, mintsem a minőségre.

\subsubsection{E-SQ (2002)}

A SERVQUAL skálából kiindulva, valamint az online szolgáltatásminőség mérésére készített, meglévő szakirodalmi tanulmányok és skálák alapján Zeithaml, Parasuraman és Malhotra kezdetben öt dimenziót fogalmazott meg az elektronikus szolgáltatásminőséggel kapcsolatban (Parasuraman et al., 2002):

1. információ szavahihetősége, tartalma;

2. egyszerü használat;

3. biztonság;

4. grafikai stílus;

5. megbízhatóság, végrehajtás/teljesítés.

A 2005-ben megalkotott skálájukhoz felhasználták ezeket az eredményeket.

\subsection{8. eTAILQ (2003)}

A következő skála Wolfinbarger és Gilly nevéhez köthetö, és célja azoknak a dimenzióknak a feltárása, amelyek a minőségi, kielégítő online vásárláshoz szükségesek. Kiindulópontjukat a számítógépes környezeti vizsgálatok adták. Ebben a közegben a 
kutatók sokat koncentráltak a flow élményre, az információ elérhetőségére, a megjelenítésre, az interaktivitásra, a grafikai stílusra, a használhatóságra, a keresési funkciókra, a teljes honlapdesignra, illetve a rendelési folyamatra (Hoffman - Novak, 1996; Montoya-Weiss et al., 2000; Novak et al., 2000).

A legtöbb korábbi elektronikus szolgáltatásminőségről végzett kutatás is ezekből indult ki, azonban Wolfinbarger és Gilly $(2002,2003)$ véleménye szerint ezeket a számítógépes környezetre vonatkozó elméleteket finomítnai kell, hogy az e-kereskedelem területén alkalmazhatók legyenek. Kiindulásként ők is a következő dimenziókat vették figyelembe: használhatóság, információtartalom, megbízhatóság, ügyfélszolgálat, választék, biztonság/adatvédelem, tapasztalati minőség.

A kutatásuk során 9 offline és online fókuszcsoportot folytattak le online vásárlókkal, akik termékeket és szolgáltatásokat is vásároltak (CD, könyv, software, hardware, játék, utazás).

Az első fázisban, melynek során egy 18+-os online panelt használtak, megalkották a .comQ skálát (Wolfinbarger - Gilly, 2002), amelyet a következő évben már tovább is fejlesztettek. A végleges skála, az eTAILQ négy dimenzió mentén méri az elektronikus szolgáltatásminőséget:

1. Megbizhatóság (3 elem): a fogyasztó azt kapja-e, amit a leírás alapján elképzelt, a megfelelő terméket, az ígért feltételek mellett szállítják-e.

2. Design (5 elem): minden olyan elemet tartalmaz, amellyel a fogyasztó a honlap használatakor találkozik, mint például navigáció, keresési lehetőség, rendelési folyamat stb.

3. Biztonság, adatvédelem (3 elem): a bankkártyás fizetés, illetve a saját adatok biztonsága.

4. Vevőszolgálat (3 elem): segítőkész vevőszolgálat, amely a fogyasztói kérdésekre időben válaszol (Wolfinbarger - Gilly, 2003).

A megalkotott skála megfelelő validitással és megbízhatósággal bír, és az eTAILQ Parasuraman és társai szerint (2005) is kielégítően körbejárja az elektronikus szolgáltatásminőség kategóriáját. Bauer és szerzőtársai is kiemelik és elismerik, hogy a minőség 70\%-át magyarázzák a dimenziók, de kritikaként jelölik meg, hogy a vásárlás hedonista vetületével nem törődik a skála (Bauer et al., 2006). A szerzők a kifejlesztett 
skála korlátjaként a panel használatát nevezik meg a random mintavétel helyett (Wolfinbarger - Gilly, 2002).

\subsubsection{E-S-Qual és E-RecS-Qual (2005)}

A 2000-es évek közepére az elektronikus szolgáltatásminőség irodalma már megfelelő alapokkal bírt, és ezeket szintetizálva alkotta meg Parasuraman, Zeithaml és Malhotra az E-S-Qual és E-RecS-Qual skálák együttesét (2005), melyet az olyan honlapokkal kapcsolatos szolgáltatásminőség mérésére fejlesztettek ki, amelyeken online lehet vásárolni. A 2002-ben megalkotott E-SQ skála mindegyik dimenziója relevánsnak bizonyult az elektronikus szolgáltatások minőségével kapcsolatban a későbbi tanulmányok során. Wolfinbarger és Gilly (2003) eredményei alátámasztják, hogy a fogyasztói elégedettséggel kapcsolatban a megbízhatóság számít a legfontosabb elemnek, illetve az újravásárlás kapcsán is kiemelt jelentőséggel bír ez a tényező. Ezeket az eredményeket Parasuraman és társainak (2005) későbbi munkássága azzal egészíti ki, hogy a honlap megítélése nem csak az ott töltött idő alatt bekövetkezett interakciók minőségétől függ, hanem az utólagos interakciók, illetve a teljesítés is jelentősen befolyásolja azt.

A skála kialításához a szerzők kvalitatív technikákkal 11 kiemelt jellemzőt azonosítottak az e-szolgáltatásokkal kapcsolatban:

1. Megbízhatóság: az oldal megfelelő müszaki müködése, a szolgáltatási ígéretek, például számlázás, termékinformációk pontossága (raktárkészletek, azt szállítják, amit a vevő rendelt, akkor szállítják, amikorra megígérik).

2. Reagálási képesség: gyors reagálás, illetve segítség, ha valami gond adódik.

3. Hozzáférés: a honlap gyors elérésének lehetősége, illetve a vállalat, kapcsolattartó elérhetőségének biztosítása.

4. Rugalmasság: fizetés, vásárlás stb. módjának kiválasztása.

5. Egyszerű navigáció: olyan funkciók megléte, amelyek különösebb nehézségek nélkül segítenek megtalálni, amit a fogyasztó keres, lehetséges legyen könnyen oda-vissza ugrálni a honlapon.

6. Hatékonyság: egyszerü használat, jól strukturált felépítés, minimális információigény a fogyasztóktól.

7. Garancia, bizalom: a fogyasztó biztonságban érezze magát az oldal használatakor, jó hírneve legyen, egyszerü és hiteles információkat tartalmazzon. 
8. Biztonság, adatvédelem: a fogyasztó bizalma abban, hogy a honlapon a személyes információkat megfelelő védelemmel kezelik.

9. Árismeret: teljes ár megtekinthetősége, összehasonlíthatóság.

10. Esztétika.

11. Testreszabás, egyénre szabás: milyen egyszerüen lehet a honlapot az egyéni igényeknek megfelelően alakítani, múltbéli események, tranzakciók visszakereshetősége.

Az E-S-Qual skála kialakításához végül 121 olyan elemet fogalmaztak meg, amelyek fontosak lehetnek a minőség mérése szempontjából. Az eredmények alapján négy dimenziót határoztak meg:

1. Hatékonyság (8 elem): a honlap elérését, illetve használatát egyszerüség és gyorsaság jellemzi.

2. Megbízhatóság, teljesités (7 elem): a kínált és a kézhez vett termék jellemzői megegyeznek, illetve a szállítás feltételi teljesültek.

3. Rendszer elérhetősége (4 elem): megfelelő technikai funkciók megléte a honlapon.

4. Biztonság (3 elem): annak a foka, hogy mennyire biztonságos az oldal, illetve milyen szinten biztosítja az adatok védelmét.

Az E-S-Qualt emellett kiegészítették egy háromdimenziós skálával, az E-RecS-Quallal (electronic recovery service quality), melyet csak azoknak a fogyasztóknak kell értékelni, akik valamilyen módon kapcsolatba léptek a vevőszolgálattal. A helyreállítás (recovery) dimenziót Parasuramanék hozzák be először az elektronikus szolgáltatásminőség mérése kapcsán. Azért építették ezt egy külön skálába, mert úgy gondolták, hogy nem minden fogyasztó számára releváns ez a téma, és így a torzításokat ki lehet szürni. Az E-RecSQual a következő dimenziókat tartalmazza:

1. Válaszadó készség (5 elem): a problémák hatékony kezelése.

2. Kompenzáció (3 elem): amelyet problémák esetén nyújtanak.

3. Kapcsolati lehetőség (3 elem): telefonos vagy online rendelkezésre állás.

Az E-S-Qual tehát egy négydimenziós, 22 indikátort magába foglaló skála, melyet az elektronikus szolgáltatások minőségének mérésére fejlesztettek ki, és a részletesebb 
információk érdekében kialakították mellé egy kiegészítő skálát, az E-RecS-Qualt, mely három dimenziót és 11 mérési tételt tartalmaz. A különböző elemeket a válaszadók 1-től 5-ig terjedő skálán értékelik az alapján, hogy az adott kijelentéssel mennyire értenek egyet a vizsgált honlap esetében. Mindkét skála megfelelö érvényességi és megbízhatósági szinttel rendelkezik. A skála megbízhatóságát tovább növeli, hogy egy jól ismert és sokat alkalmazott modell, a SERVQUAL továbbfejlesztéseként hozták létre (Vallejo et al., 2005).

Az eredmények alapján megállapítható, hogy a hatékonyság és a megbízhatóság a szolgáltatásminőség mellett jelentős hatással bír a fogyasztói bizalomra, illetve a lojalitásra is. A rendszerelérhetőség dimenziójának jelentősége pedig azt bizonyítja, hogy egy honlap megítélése nemcsak a kialakításon múlik, hanem egyéb külső tényezők, mint például a fogyasztó otthoni internetkapcsolatának minősége is befolyásolhatják. A biztonság - mint ahogy azt korábbi kutatások is kiemelték - továbbra is jelentős kategória.

A skála nem foglalkozik az élvezet és élmény kategóriájával, mivel a szerzők véleménye szerint a webshopok esetében ezek nem jelentősek (Parasuraman et al., 2005). Bauer és társainak (2006) véleménye szerint a honlapok is nyújtanak olyan lehetőségeket, amelyek emocionális választ eredményeznek (Van Riel et al., 2001; Yoo - Donthu, 2001), vagyis a flow érzések az interneten is megjelennek (Childers et al., 2001; Csikszentmihályi, 1988; Hoffman - Novak, 1996). Emellett az E-RecS-Qual esetében a válaszadó készség nem a másodlagos, hanem a fó csoportba kell, hogy tartozzon, mivel ez a biztonság, a hitelesség érzetét növeli (Bauer et al., 2006). Vallejo, López, Aguilar és Lombardo (2005) véleménye szerint is tovább kell fejleszteni a skálát, mivel a lojalitás mérésére nem alkalmazható tökéletesen.

Az E-S-Qual és E-RecS-Qual skálák módosítását is létrehozták már. Akinci és társai (2010) a pénzügyi szektorra adaptálták a skálát, melynek kevesebb megfogható eleme van. A skálának egy ilyen tiszta szolgáltatás jellegü (pure service) szektorra való kiterjesztését már a megalkotásakor is jövőbeli kutatási irányként jelölték meg (Parasuraman et al., 2005). 
Ebben a tiszta szolgáltatási környezetben a teljesítés dimenzió 7 mérési tételéből mindössze 2 maradt meg ${ }^{1}$, és a mélyinterjúk alapján új, releváns elemeket azonosították ${ }^{2}$. Emellett az adatvédelem dimenzióját is módosították. ${ }^{3}$ A végleges, banki szolgáltatások esetében használható E-S-Qual és E-RecS-Qual skálát 2017 fő válaszai alapján alkották meg (Akinci et al., 2010).

\subsubsection{0. eTRANSQual (2006)}

Az eTRANSQual skála megalkotásakor Bauer és társainak (2006) célja az volt, hogy a célorientált vásárlás mellett az elektronikus vásárlások esetében eddig nem vizsgált hedonista értékeket is beépítsék az elektronikus szolgáltatásminőség koncepciójába. A szerzők további célként tűzték ki az eddigi skálák hibáinak feltárását, illetve a jó ötletek továbbvitelét. Az interjúk után egy német online panel tagjainak küldték ki a kérdőívet egy ismert webshoppal kapcsolatban, és az eredmények alapján öt dimenziót azonosítottak:

1. funkcionalitás/design (7 mérési tétel),

2. élvezet (4 mérési tétel),

3. folyamat (4 mérési tétel),

4. megbízhatóság (6 mérési tétel),

5. válaszadó készség (4 mérési tétel).

A kutatással tehát sikerült egy olyan skálát létrehozni, amely a hedonista értékeket is tartalmazza. A válaszadó készség jelentős hatása is azt mutatja, hogy ennek a fő skálában van a helye, nem a mellék skálában, ahova Parasuramanék (2005) helyezték, mivel ez nemcsak valamilyen probléma felmerülése esetében jelentős, hanem a használatbavétel eldöntésekor is. Az észlelt értékkel és elégedettséggel mindegyik dimenzió pozitív kapcsolatot mutat, az élvezet pedig az újravásárlással is pozitív kapcsolatban áll (Bauer et al., 2006). A megalkotott dimenziók közül azonban az élvezet és a folyamat mutatják

\footnotetext{
${ }^{1}$ Nem használt elemek: „This site makes items available for delivery within in a suitable time frame.”, „It quickly delivers what I order.”, „It sends out the items ordered.”, „It has in stock the items the company claims to have.", „It is truthful about its offerings.”

Adatvédelem: „This site protects information about my credit card.

${ }^{2}$ Új mérési tételek: „Records at my bank's Web site are always accurate.”, „My bank's Web site promptly informs about important situations (payments ...)."

${ }^{3}$ Új mérési tétel: „I feel confident for thetransactions I made at my bank’sWeb site.”
} 
a leggyengébb kapcsolatot a minőségészleléssel, így felmerülhet a kérdés, hogy az ekereskedelem hedonista jellege a minőség szempontjából valóban releváns-e.

\subsubsection{E-A-S-Qual (2006)}

Az E-A-S-Qual skála, mint ahogy már az elnevezése is sugallja, az E-S-Qual és E-RecSQual skálák (2005) továbbfejlesztett változata. Kim, Kim és Lennon (2006) választása azért esett erre a skálára, mert kiindulási pontját a jól ismert és sokat alkalmazott SERVQUAL skála adja. További érdeme, hogy Parasuramanék a skála megalkotáskor nem hallgatói megkérdezést alkalmaztak, hanem a téma szempontjából releváns mintával dolgoztak.

Az E-S-Qual skála dimenziói a szakirodalmi felvetéseknek is megfelelnek. A hatékonyság, vagyis az egyszerü, gyors elérés és használat az online vásárlás időspóroló jellege miatt is jelentős (Ranganathan - Ganapathy, 2002), és a teljesítés több kutatás alapján is az egyik legjelentősebb tényező (Wolfinbarger - Gilly, 2003). A biztonság az észlelt kockázat miatt jelentős, az elérhetőség, a nem működő linkek, a hiányzó információk pedig frusztrációhoz vezetnek. Santos (2003) szerint a hiányzó és nem müködő linkek száma növeli az elégedetlenséget.

Egy új skála megalkotásának ötlete abból származott, hogy a szerzők véleménye szerint az eddigi skálák (Attitude toward the Site: Chen - Wells, 1999; WebQual: Barnes Vidgen, 2000; SITEQUAL: Yoo - Donthu, 2001; WebQual ${ }^{T M}$ : Loiacono et al., 2002; e$S Q$ : Zeithaml et al., 2002; eTAILQ: Wolfinbarger - Gilly, 2003) túlzottan szubjektíven értékelnek, ezért szükség van egy objektív mérési metódusra. Céljuk, hogy meghatározzák azokat a tényezőket, amelyek a hatékony és hatásásos vásárlást, szállítást segítik, illetve objektív mérést biztosítanak. Az E-A-S-Qual skála összesen 9 dimenziót tartalmaz; ebböl hatot az E-S-Qualból és E-RecS-Qualból vettek át - kivétel a kompenzáció -, továbbá beleveszik még a személyre szabás (Wolfinbarger - Gilly, 2003), információminőség és -mennyiség, illetve a grafikai stílus dimenziókat is (Kim et al., 2006).

Az információ dimenziója azért fontos, mert Lynch és Ariely (2000) eredményei alapján az információk a termékről, minőségről, árról pozitívan befolyásolják az elégedettséget, emellett más lehetőség a tapasztalásra online környezetben nincs, mivel nincs eladó, és a termék sem megfogható (Kim - Stoel, 2005). A grafikai stílus faktor (szín, layout, printméret, fotók száma, grafikák, animációk) használata azért fontos, mert ezek 
befolyásolják az online vásárlásról alkotott percepciókat (Nitse et al., 2004). A kutatás eredményeként nem egy skála született, hanem egy lista (check list), mely minden olyan elemet tartalmaz, ami a minőséghez elengedhetetlen.

\subsubsection{RECIPE (2009)}

A RECIPE (Review and Evaluate the Customer's Internet Purchase Experience) skála megalkotásának egyik alapgondolata, hogy még mindig kevés olyan skála létezik a szakirodalomban, amely az elektronikus szolgáltatásminőség definíciójának teljesen megfelel (PIRQUAL, eTailQ, E-S-Qual és E-RecS-Qual), vagyis a vásárlás mellett mind a pre-, mind pedig a posztinterakciós aspektusokat tartalmazza (Parasuraman et al., 2005). A másik probléma, ami egy új skála létrehozását sürgeti, hogy a korábban említett három skálából kettő csak a megfogható termékekkel, az ún. offline-termékekkel foglalkozik. Az eTAILQ figyelembe veszi az offline-szolgáltatásokat is, azonban az elektronikustermékek és szolgáltatások területén még nem történt vizsgálat, illetve skálaalkotás. Meglepő, hogy idáig a többség az offline-termékekre koncentrált, mivel számos vásárlás történik a további kategóriákban is. Igaz, egyes tanulmányok felhívják a figyelmet, hogy a termékkategóriák és teljesítési/szállítási módok alapján eltérés figyelhető meg, és a skálát módosítani kell.

Francis a kutatás első, feltáró szakaszában 40 interjút (25 férfi - 15 nő, 25-53 év) készített olyanokkal, akik már vásároltak a világhálón. Célja, hogy a különböző internetes vásárlási formákat azonosítsa és megvizsgálja, valamint kialakítson egy minőségmérő skálát minden egyes kategória vonatkozásában. Véleménye szerint ez azért fontos, mert az, hogy minden egyes e-kereskedelmi esetet egy kalap alatt kezeljenek, nem sikeres az internetes vásárlás esetében.

Az első feltáró kutatás (Francis, 2007) négy dimenziót különböztet meg, és mindegyikben azonosítja a releváns minőségelemeket. Minden egyes minőségskála tartalmazza a honlapminőség, a tranzakció/szállítás, az ügyfélszolgálat, illetve a biztonság faktorokat, azonban az egyes termékek és szállítási/teljesítési módok esetében a kategóriák mérési tételei különböznek. A további kutatások célja ezeknek a skáláknak a finomítása.

A 2009-ben publikált kutatásban az offline-termékek esetében létrehozott skála 4 dimenziót tartalmaz 19 mérési tétellel, az offline-szolgáltatások esetében 4 dimenziót 18 mérési tétellel, az elektronikus-termékek esetében 4 dimenziót, 19 mérési tétellel, míg az 
elektronikus-szolgáltatások esetében 4 dimenziót, 20 mérési tétellel. A dimenziókat a különböző kategóriákban a 4. táblázat tartalmazza.

\begin{tabular}{|c|c|}
\hline Offline-termék & Offline--szolgáltatás \\
\hline Honlapminőség & Honlapminőség \\
\hline Csere: fizetés és kézhezvétel & $\begin{array}{c}\text { Foglalás/vásárlás - a foglalás megerösítésére } \\
\text { és folyamatára koncentrál }\end{array}$ \\
\hline Ügyfélszolgálat & Ügyfélszolgálat \\
\hline Biztonság & Biztonság \\
\hline Elektronikus-termék & Elektronikus-szolgáltatás \\
\hline Csere: fizetés és kézhezvétel & Relhasználói fióklétrehozás \\
\hline Termékrészletek & Ügyfélszolgálat \\
\hline Ügyfélszolgálat & Biztonság \\
\hline Biztonság &
\end{tabular}

\section{4. táblázat: A RECIPE skála dimenziói}

Forrás: szakirodalom alapján saját szerkesztés (Francis, 2009)

A négy kategória esetében azonos a biztonság, vagyis a kártyaadatok és a személyes információk biztonsága, valamint az ügyfélszolgálat dimenziója, úgymint a cég elérhetősége, gyorsasága, segítőkészsége. A többi dimenzió esetében jelentős eltérések figyelhetőek meg. A honlap minőség az offline-termékek és szolgáltatások esetében hasonló elemeket tartalmaz, úgymint a design, tartalom, termékek száma. Az elektronikus-termékek esetében inkább a termékjellemzőkre koncentrál (méret, rendszerfeltételek, kompatibilitás) a kategória, míg az online-szolgáltatások esetében a felhasználói fiók létrehozásának egyszerüsége, gyorsasága a kiemelt. A fizetésre és kézhezvételre vonatkozó kategória mindenhol megjelenik. Offline-termék esetében ide tartozik a rendelés megvalósítása, a megfelelő termék jó időben történő szállítása, míg az elektronikus-terméknél a teljesítés minősége, a letöltési instrukciók egyértelmüsége és a gyorsaság. Offline-szolgáltatásoknál a foglalás egyszerűsége, megbízhatósága, az egyértelmü, gyors visszaigazolás, az elektronikus-szolgáltatásoknál pedig az egyszerü, megbízható bejelentkezés, az egyszerü használat és a szolgáltatás leírása a fontos.

A kutatás során megvizsgálták a dimenziók hatását a lojalitási szándékra, és a különböző kategóriákban eltérő eredmények születtek: az offline-termékek esetében a csere dimenzió $(0,372)$, offline-szolgáltatásoknál a foglalás/vásárlás $(0,357)$, az elektronikusterméknél a termékrészletek (0,221), az elektronikus-szolgáltatásoknál pedig az ügyfélszolgálat(0,327) volt a legjelentősebb (Francis, 2009).

A megalkotott koncepció inkább egy folyamatorientált minőségképet nyújt, mintsem érzelmek által vezérelt, tehát a hedonista motivációkat nem veszi figyelembe, és reflektív indikátorként jeleníti meg az egész fogalmat. Emellett csak a kategóriák direkt hatását 
vizsgálja a lojalitás alakulásában. A korábban létrehozott skálákat is ez alapján kellene módosítani és finomítani. Azonban a RECIPE is egy friss skála, amelynek keresztvalidálására, különböző kultúrák közti tesztelésére lenne szükség, és a skála továbbbővítése szempontjából érdemes lenne az involvement és a bizalom kategóriáját is figyelembe venni (Francis, 2009).

\subsubsection{3. Összefoglalás}

Ahogy a fentebb ismertetett koncepciók is mutatják, az elektronikus szolgáltatásminőség leírására és mérésére szolgáló megközelítések jelentősen eltérnek egymástól a használt kulcsdimenziók tekintetében. Általánosságban megállapítható, hogy az elektronikus szolgáltatásminőség szubjektív kategória, melyet a fogyasztók az alapján értékelnek, hogy az elvárt és kapott szolgáltatásminőség között milyen kapcsolat áll fenn, vagyis milyen élménnyel gazdagodtak a vásárlásuk folyamata során.

Mint korábban említettem, az elektronikus szolgáltatásminőség kialakulása a vásárlás teljes folyamatára kiterjed, azonban vannak olyan mérési módszerek, amelyek csak a felületre, vagyis a honlapra koncentrálnak, így nem nyújtanak teljes képet az elektronikus szolgáltatásminőségről, és ez által az elégedettség megismerésére sem alkalmasak. A kritikák alapján Barnes és Vidgen (2001), valamint Loiacono és társainak (2000) skálái inkább a technikai minőségre koncentrálnak, emellett az utóbbi leginkább egy átfogó tanulmánynak számít (Parasuraman et al., 2005; Wolfinbarger - Gilly, 2003), melynek a fókusza inkább a design mintsem az e-szolgáltatásminőség (Zeithaml et al., 2002). Az eTAILQ skála esetében (Wolfinbarger - Gilly, 2003) Parasuramanék kritikája szerint a biztonság/adatvédelem, illetve a teljesítés/megbízhatóság dimenziók látszatérvényessége (face validity) rendben van, a másik két dimenzióhoz tartozó állításoknak nincs meg a belső egységessége.

Bauer és társai szerint függetlenül a skálák értékelésétől a legfontosabb jövőbeli kutatási irányt a területen a longitudinális tanulmányok készítése jelentené, illetve a piacorientáció és az innovativitás beépítése a mérésekbe (Bauer et al., 2006).

Az elektronikus szolgáltatásminőség koncepciókkal kapcsolatban nem csak kritikák, hanem összefoglalók is születtek. Bressoles és társainak 2007-es összegzése az addig megszületett skálák alapján hat fő dimenziót nevez meg az elektronikus szolgáltatásminőséggel kapcsolatban. 
1. Az információ minősége és mennyisége, mely sokszor az online vásárlás indokaként is megjelenik (Barnes - Vidgen, 2003; Wolfinbarger - Gilly, 2003). Mivel nincs direkt kontaktus az eladóval, ezért kiemelt ez a terület. Ide tartoznak a kereskedelmi és technikai információk a termékről, szolgáltatásról, a szolgáltatásnyújtóról, a szerződésről/feltételekről.

2. A használat egyszerüsége azért fontos, mert az online vásárlás egy komplex folyamatot jelent számos vásárló számára (Eighmey, 1997). A használhatóság dimenziójába tartozik a struktúra és a navigáció egyszerüsége.

3. A design, vagyis a grafikai megjelenítés (grafika, színek, képek, ikonok, animációk, videók stb.) a virtuális atmoszféra kialakítását jelenti, ezért jelentős a minőségészlelés során.

4. A megbizhatóság és a vállalt kötelezettségek betartása dimenzióba tartozik az ígéretek teljesítése/teljesülése, úgymint a megfelelő időben történő szállítás, a megfelelő termék, feltételek stb.

5. A megbizhatóság és adatvédelem a csalásoktól, pénzügyi veszteségektől való védelmet takarja.

6. Az interaktivitás és a személyre szabás lehetősége, olyan terméket, szolgáltatást, vagy felület létrehozását jelenti a fogyasztó által, amely leginkább megfelel az ő igényeinek (Bressolles et al., 2007).

Ezzel szemben Nath és Singh (2010) összefoglalásukban az elektronikus szolgáltatásminőség mérése esetében három fő dimenziót különít el: (1) a technikai alapú, teljesítménytényezőket, (2) a környezeti és információs dimenziókat, illetve (3) a nem technikai alapú faktorokat.

Az első csoportba, a technikai alapú teljesítménytényezők közé véleményük szerint az alábbi kategóriák tartoznak:

1. Elérhetöség - a honlap állandó elérhetősége.

2. Hozzáférhetőség/kiszolgálóképesség - a webshop képes-e az igényeket, kéréseket kiszolgálni. Előfordulhat, hogy a szolgáltató elérhető, de a magas igénybevétel miatt a szolgáltatás nem.

3. Teljesitmény/eredmény - mennyi kérést képes kielégíteni az adott időben.

4. Lappangási idő - a kérés elküldése és a válasz között eltelt idő. 
A környezeti minőség a felület által nyújtott minőséget, míg az információminőség a teljes, pontos és időszerü információkat jelöli. A nem technikai dimenziók a következőképpen alakulnak:

1. Outcome-minöség -vagyis mit visz magával a fogyasztó a teljesítés után, hogyan alakul az elégedettsége. Ennek alcsoportjai:

a. Megbízhatóság - mennyire tartja be az ígéreteit az e-kereskedő.

b. Funkcionális értékek - milyen szinten teljesíti azt, amire ki lett találva a webshop.

c. Érzelmi értékek - a Fassnacht és Koese (2006) általi érzelmi előnyök/értékek dimenzióját foglalja magában, mivel a teljes élményt, illetve tapasztalatot tartalmazza.

2. Támogatás - az IT területén különösen fontos terület, melyhez a következő tényezők sorolhatóak:

a. Válaszadó készség - válaszadás gyorsasága és akarása.

b. Megbízhatóság - teljesítik-e azt, amit ígértek, pl. időben válaszolnak.

c. Kompetenciák - a támogatás technikai szintje és szakmaisága.

d. Empátia - a különböző igények megértésének képessége.

e. Training - az instrukciók és támogatás mértéke, amellyel a legjobb használatot kívánják támogatni.

\section{Adatvédelem}

4. Helyreállitás - a fogyasztók sokszor úgy érzik, hogy a gondok helyreállítására nem szánnak elég időt. Ez a dimenzió annak a foka, hogy gond esetén mennyire akarja, mennyire támogatja a webshop a problémák helyreállítását. Alcsoportjai:

a. Interaktív korrektség - mennyire könnyü elérni a támogatókat.

b. Ügyrendi korrektség - a visszavásárlási politika/szabályok, milyen gyorsan érvényesítik ezeket.

c. Kimeneti/outcome korrektség (Collier - Benstock, 2006) - pénzügyi kompenzáció, bocsánatkérés (Nath - Singh, 2010).

Véleményünk szerint a bemutatott koncepciók értékelésekor az elsődleges szempont, hogy a vizsgált skálák mennyire felelnek meg az elektronikus szolgáltatásminőség definíciójának, illetve figyelembe veszik-e az e-kereskedelem heterogén jellegét a kínált termékek/szolgáltatások tekintetében. Ahogy az összefoglaló táblázat is mutatja (5. táblázat) az elektronikus szolgáltatásminőség definíciójának - vagyis hogy az 
információnyújtástól a vásárláson át a problémák, kérdések kezeléséig minden területet figyelembe vesznek - az ismertetett skálák közül öt felelt meg: a PIRQUAL (Francis White, 2002), az eTAILQ (Wolfinbarger - Gilly, 2003), E-S-Qual és E-RecS-Qual (Parasuraman et al., 2005), az e-TRANSQUAL (Bauer et al., 2006), valamint a RECIPE (Francis, 2009).

\begin{tabular}{|c|c|c|c|c|c|c|}
\hline & \multirow{2}{*}{$\begin{array}{l}\text { E-kereskedelmi } \\
\text { kategória }\end{array}$} & \multicolumn{4}{|c|}{$\begin{array}{l}\text { Értékelés: Elektronikus szolgáltatásminôség koncepció } \\
\text { lefedése }\end{array}$} & \multirow[b]{2}{*}{ Biztonság } \\
\hline & & $\begin{array}{l}\text { Információ- } \\
\text { keresés }\end{array}$ & Tranzakció & Szállítás & \begin{tabular}{|l} 
Kapcsolat, \\
ïgyfélszolg.
\end{tabular} & \\
\hline WebQual TM & $\begin{array}{l}\text { Termék, szolgáltatás } \\
\text { egyben }\end{array}$ & $\checkmark$ & $\checkmark$ & 凶 & 区 & $\checkmark$ \\
\hline WebQual 1.0 & Egyetemi honlap & $\checkmark$ & $\checkmark$ & 凶 & 凶 & $\checkmark$ \\
\hline WebQual 2.0 & Általános honlap & $\checkmark$ & $\checkmark$ & 凶 & 凶 & $\checkmark$ \\
\hline WebQual 3.0 & Általános honlap & $\checkmark$ & $\checkmark$ & $\mathrm{X}$ & 凶 & $\checkmark$ \\
\hline SITEQUAL & $\begin{array}{c}\begin{array}{c}\text { Termék, szolgáltatás } \\
\text { egyben }\end{array} \\
\end{array}$ & $\checkmark$ & $\checkmark$ & 凶 & $凶$ & $\checkmark$ \\
\hline PIRQUAL & Nem emeli ki & $\checkmark$ & $\checkmark$ & $\checkmark$ & $\checkmark$ & $\checkmark$ \\
\hline WebQual 4.0 & Termék & $\checkmark$ & $\checkmark$ & 凶 & 凶 & $\checkmark$ \\
\hline ETAILQ & $\begin{array}{l}\text { Termék, szolgáltatás } \\
\text { egyben }\end{array}$ & $\checkmark$ & $\checkmark$ & $\checkmark$ & $\checkmark$ & $\checkmark$ \\
\hline $\begin{array}{l}\text { E-S-Qual és } \\
\text { E-RecS-Qual }\end{array}$ & Termék & $\checkmark$ & $\checkmark$ & $\checkmark$ & $\checkmark$ & $\checkmark$ \\
\hline e-TRANSQUAL & Termék & $\checkmark$ & $\checkmark$ & $\checkmark$ & $\checkmark$ & $\checkmark$ \\
\hline RECIPE & $\begin{array}{c}\text { Négy változat: } \\
\text { offline-termék, } \\
\text { offline-szolgáltatás, } \\
\text { elektronikus-termék, } \\
\text { elektronikus-szolg. } \\
\text { esetére }\end{array}$ & $\checkmark$ & $\checkmark$ & $\checkmark$ & $\checkmark$ & $\checkmark$ \\
\hline $\begin{array}{l}\text { E-S-Qual és } \\
\text { E-RecS-Qual } \\
\text { Bank }\end{array}$ & $\begin{array}{c}\text { Elektronikus- } \\
\text { szolgáltatás } \\
\text { BANK } \\
\end{array}$ & $\checkmark$ & $\checkmark$ & $\checkmark$ & $\checkmark$ & $\checkmark$ \\
\hline
\end{tabular}

\section{5. táblázat: A megvizsgált elektronikus szolgáltatásminőség skálák értékelése az e-szolgáltatásminőség definíció tükrében}

Forrás: saját értékelés alapján saját szerkesztés

Az e-kereskedelem heterogén jellegét azonban Francis kivételével senki sem vette figyelembe. Parasuramanék munkájuk során ajánlják a skála kiterjesztését a szolgáltatásokra (2005), melyet Akinci és társai 2010-ben meg is tesznek az e-banking területére, mely az elektronikus-szolgáltatások kategóriába tartozik, azonban két terület - az offline-szolgáltatás és az elektronikus-termék - továbbra is hiányzik. Az e-TAILQ kivételével mindegyik skála csak a termékekre koncentrál, azonban az elektronikustermékek és szolgáltatások minden esetben hiányoznak. Emellett az e-TAILQ esetében úgy véljük, a teljesítés dimenzió sem fedi le egyértelmüen az offline-szolgáltatások 
területét, amikor is a visszaigazolás, illetve a voucher „kézhezvétele” általában online történik, ezért a mérési tételek kicsit más megfogalmazást igényelnének. ${ }^{4}$

Az elektronikus kereskedelem kapcsán számos esetben felmerül a visszaélések, a csalás lehetősége, ezért tartják az egész folyamat során a biztonság kérdését kulcsdimenziónak. A megvizsgált skálák esetében a WebQual 1.0 és 2.0 kivételével ez a dimenzió mindig megjelenik.

Az elektronikus szolgáltatásminőség dimenzióinak elemzése során különböző függő változókkal találkozhatunk: vannak skálák, amelyek az elégedettséggel való kapcsolatot mérik, mások direkt hatást feltételeznek a használhatósággal, az újrahasználattal kapcsolatban, míg egyesek a lojalitással való összefüggést elemzik (6. táblázat). A WebQual skálák esetében nem összefüggést vizsgálnak, hanem egy indexet alakítanak ki, amellyel a legnagyobb hiányosságokra és a fejlesztési területekre hívják fel a figyelmet. Egy kormányzati honlap esetében az indexek értékei alapján történő fejlesztések után jelentősen javult a fogyasztói értékelés, valamint az index mértéke (Barnes - Vidgen, 2003).

Az értékelés alapján az általunk elfogadott elektronikus szolgáltatásminőség definíciónak, illetve az e-kereskedelem négy kategóriába való besorolhatóságának egyedül a RECIPE skála felelt meg, ezért empirikus kutatásunk során ezt tervezzük alkalmazni.

The product that came was represented accurately by the website.

The product is delivered by the time promised by the company. 


\begin{tabular}{|c|c|c|c|c|c|c|c|c|c|}
\hline Skála & Szerző & Év & $\begin{array}{l}\text { Dimenziók és } \\
\text { mérési tételek } \\
\text { száma }\end{array}$ & Dimenziók & $\begin{array}{l}\text { Cronbach- } \\
\text { alfa }\end{array}$ & Megjelenés helye & $\mathbf{N}$ & Minta & Függö változók \\
\hline N.a & Liu-Arnett & 2000 & $4 / 28$ & $\begin{array}{l}\text { 1. Az információ és a szolgáltatások } \\
\text { minősége (12 elem) } \\
\text { 2. Rendszerhasználat ( } 7 \text { elem) } \\
\text { 3. Játékosság, interaktivitás, élvezet ( } 5 \text { elem) } \\
\text { 4. Design (4 elem) }\end{array}$ & $\begin{array}{l}\alpha=0,88 \\
\alpha=0,92 \\
\alpha=0,83 \\
\alpha=0,63\end{array}$ & $\begin{array}{c}\text { Information \& } \\
\text { Management }\end{array}$ & 122 & $\begin{array}{l}\text { Fortune } 1000 \\
\text { cégek } \\
\text { webmesterei }\end{array}$ & $\begin{array}{l}\text { Weblap sikeréhez } \\
\text { vezetö tényezök }\end{array}$ \\
\hline WebQual $^{\mathrm{TM}}$ & $\begin{array}{l}\text { Loiacono, } \\
\text { Watson, } \\
\text { Goodhue }\end{array}$ & $\begin{array}{c}2000 \\
\text { ősz } \\
2000 \\
\text { tavasz } \\
2002 \\
2007\end{array}$ & $12 / 36$ & $\begin{array}{l}\text { 1. Az információ illeszkedése ( } 3 \text { elem) } \\
\text { 2. Interakció ( } 3 \text { elem) } \\
\text { 3. Teljes online szolgáltatás ( } 3 \text { elem) } \\
\text { 4. Relatív hasznosság ( } 3 \text { elem) } \\
\text { 5. Intuitív kezelési felület, egyszerü használat } \\
(3 \text { elem) } \\
\text { 6. Design, megértés egyszerüsége }(3 \text { elem) } \\
\text { 7. Bizalom - adatvédelem ( } 3 \text { elem) } \\
\text { 8. Válaszadási idő ( } 3 \text { elem) } \\
\text { 9. Vizuális megjelenítés }(3 \text { elem) } \\
\text { 10. Innovativitás - AHA érzés }(3 \text { elem) } \\
\text { 11. Érzelmi befolyás }(3 \text { elem) } \\
\text { 12. Konzisztens imázs }(3 \text { elem) }\end{array}$ & $\begin{array}{l}\alpha=0,86 / 0,85 \\
\alpha=0,80 / 0,78 \\
\alpha=0,72 / 0,71 \\
\alpha=0,81 / 0,8 \\
\alpha=0,79 / 0,83 \\
\alpha=0,83 / 0,81 \\
\alpha=0,9 / 0,93 \\
\alpha=0,88 / 0,8 \\
\alpha=0,93 / 0,91 \\
\alpha=0,93 / 0,91 \\
\alpha=0,81 / \text { n.a } \\
\alpha=0,87 / 0,83\end{array}$ & $\begin{array}{l}\text { International Journal of } \\
\text { Electronic Commerce } \\
\text { (2007) }\end{array}$ & $\begin{array}{l}510 \\
336 \\
311 \\
337\end{array}$ & hallgatók & $\begin{array}{l}\text { Használathatóság } \\
\text { Újrahasználati } \\
\text { szándék }\end{array}$ \\
\hline WebQual 1.0 & $\begin{array}{l}\text { Barnes - } \\
\text { Vidgen }\end{array}$ & 2001 & $4 / 23$ & $\begin{array}{l}\text { 1. Használat egyszerüsége }(3 \text { elem }) \\
\text { 2. Tapasztalat/élmény }(6 \text { elem }) \\
\text { 3. Információ }(8 \text { elem }) \\
\text { 4. Kommunikáció és integráció }(5 \text { elem }) \\
\end{array}$ & $\begin{array}{l}\alpha=0,83 \\
\alpha=0,71 \\
\alpha=0,86 \\
\alpha=0,87\end{array}$ & $\begin{array}{l}\text { Proceedings of the } \\
\text { Eighth European } \\
\text { Conference on } \\
\text { Information Systems }\end{array}$ & $35+46$ & $\begin{array}{l}\text { tanulók, majd } \\
\text { honlapon } \\
\text { vásárlók }\end{array}$ & Indexet képeznek \\
\hline WebQual 2.0 & $\begin{array}{l}\text { Barnes - } \\
\text { Vidgen }\end{array}$ & 2001 & $5 / 24$ & $\begin{array}{l}\text { 1. Használat egyszerüsége } \\
\text { 2. Tapasztalat } \\
\text { 3. Információ } \\
\text { 4. Kommunikáció és integráció } \\
\text { 5. Interakció } \\
\end{array}$ & n.a. & $\begin{array}{l}\text { International Journal of } \\
\text { Management Literature }\end{array}$ & & hallgatók & Indexet képeznek \\
\hline WebQual 3.0 & $\begin{array}{l}\text { Barnes - } \\
\text { Vidgen }\end{array}$ & 2001 & $3 / 20$ & $\begin{array}{l}\text { 1. Honlap minőség (6 elem) } \\
\text { 2. Információ minőség }(7 \text { elem) } \\
\text { 3. Szolgáltatási interakció minősége (7 elem) }\end{array}$ & $\begin{array}{l}\alpha=0,85 \\
\alpha=0,91 \\
\alpha=0,88\end{array}$ & $\begin{array}{c}\text { Proceedings of the } \\
\text { Hawaii International } \\
\text { Conference on Systems } \\
\text { Science } \\
\end{array}$ & 39 & hallgatók & Indexet képeznek \\
\hline SITEQUAL & Yoo - Donthu & 2001 & $4 / 9$ & $\begin{array}{l}\text { 1. A használat egyszerüsége (2 elem) } \\
\text { 2. Esztétikai design ( } 3 \text { elem) } \\
\text { 3. Feldolgozás sebessége }(2 \text { elem }) \\
\text { 4. Biztonság ( } 2 \text { elem })\end{array}$ & $\begin{array}{l}\alpha=0,69 \\
\alpha=0,76 \\
\alpha=0,73 \\
\alpha=0,83\end{array}$ & $\begin{array}{l}\text { Quarterly Journal of } \\
\text { Electronic Commerce }\end{array}$ & 94 & hallgatók & \begin{tabular}{|l} 
Használathatóság \\
Újrahasználati \\
szándék \\
Honlapérték \\
Honlappal \\
kapcsolatos \\
attitűd \\
Újralátogatási \\
\end{tabular} \\
\hline
\end{tabular}




\begin{tabular}{|c|c|c|c|c|c|c|c|c|c|}
\hline & & & & & & & & & \begin{tabular}{|l} 
szándék \\
Újravásárlási \\
szándék
\end{tabular} \\
\hline PIRQUAL & $\begin{array}{l}\text { Francis - } \\
\text { White }\end{array}$ & 2002 & $6 / ?$ & $\begin{array}{l}\text { 1. Honlap funkcionalitása } \\
\text { 2. Termékjellemzők leírása } \\
\text { 3. Tranzakciós rendszer } \\
\text { 4. Szállítás } \\
\text { 5. Ügyfélszolgálat } \\
\text { 6. Biztonság }\end{array}$ & & $\begin{array}{l}\text { Proceedings of } \\
\text { ANZMAC }\end{array}$ & 302 & $\begin{array}{l}\text { ausztrál } \\
\text { internetes } \\
\text { vásárlók }\end{array}$ & $\begin{array}{l}\text { Viselkedési } \\
\text { szándék }\end{array}$ \\
\hline E-SQ & $\begin{array}{l}\text { Zeithaml, } \\
\text { Parasuraman, } \\
\text { Malhotra }\end{array}$ & 2002 & 5 & $\begin{array}{l}\text { 1. Információ szavahihetősége, tartalma } \\
\text { 2. Egyszerủ használat } \\
\text { 3. Biztonság } \\
\text { 4. Grafikai stílus } \\
\text { 5. Megbízhatóság, végrehajtás/teljesítés }\end{array}$ & & $\begin{array}{l}\text { Journal of the Academy } \\
\text { of Marketing Science }\end{array}$ & & & $\begin{array}{l}\text { Szakirodalom } \\
\text { alapján }\end{array}$ \\
\hline WebQual 4.0 & $\begin{array}{l}\text { Barnes - } \\
\text { Vidgen }\end{array}$ & 2002 & $4 / 23$ & $\begin{array}{l}\text { 1. Használhatóság } \\
\text { 2. Információ minősége } \\
\text { 3. Interakció minősége } \\
\text { 4. Teljes összbenyomás a honlapról }\end{array}$ & $\begin{array}{l}\alpha=0,88 \\
\alpha=0,89 \\
\alpha=0,81\end{array}$ & $\begin{array}{l}\text { Journal of Electronic } \\
\text { Commerce Research }\end{array}$ & 376 & $\begin{array}{l}\text { Amazon, BOL, } \\
\text { Internet } \\
\text { Bookshop } \\
\text { (IBS) } \\
\end{array}$ & Indexet képeznek \\
\hline ETAILQ & $\begin{array}{c}\text { Wolfinbarger } \\
\text { - Gilly }\end{array}$ & 2003 & $4 / 14$ & $\begin{array}{l}\text { 1. Design }(5 \text { elem }) \\
\text { 2. Megbízhatóság }(3 \text { elem }) \\
\text { 3. Biztonság, adatvédelem }(3 \text { elem }) \\
\text { 4. Vevőszolgálat }(3 \text { elem })\end{array}$ & $\begin{array}{l}\alpha=0,83 \\
\alpha=0,79 \\
\alpha=0,88 \\
\alpha=0,88\end{array}$ & Journal of Retailing & & $\begin{array}{l}9 \text { fókusz, } \\
\text { diákok a } \\
\text { válogatásnál, } \\
\text { majd online } \\
\text { panel }\end{array}$ & \begin{tabular}{|l|} 
Minőség \\
Elégedettség \\
Lojalitás \\
Honlappal \\
kapcsolatos \\
attitüd
\end{tabular} \\
\hline $\begin{array}{l}\text { E-S-Qual és } \\
\text { E-RecS-Qual }\end{array}$ & $\begin{array}{l}\text { Parasuraman, } \\
\text { Zeithaml, } \\
\text { Malhotra }\end{array}$ & 2005 & $7 / 33$ & $\begin{array}{l}\text { 1. Hatékonyság }(8 \text { elem }) \\
\text { 2. Megbízhatóság, teljesítés }(7 \text { elem }) \\
\text { 3. Rendszerelérhetőség }(4 \text { elem }) \\
\text { 4. Biztonság }(3 \text { elem }) \\
\text { 5. Válaszadó készség }(5 \text { elem }) \\
\text { 6. Kompenzáció }(3 \text { elem }) \\
\text { 7. Kapcsolati lehetőség }(3 \text { elem })\end{array}$ & $\begin{array}{l}\alpha=0,94 / 0,94 \\
\alpha=0,93 / 0,94 \\
\alpha=0,86 / 0,98 \\
\alpha=0,85 / 0,83 \\
\alpha=0,72 / 0,84 \\
\alpha=0,74 / 0,73 \\
\alpha=0,72 / 0,79 \\
\alpha\end{array}$ & $\begin{array}{l}\text { Journal of Service } \\
\text { Research }\end{array}$ & $\begin{array}{l}n=650 \\
n=253\end{array}$ & $\begin{array}{l}\text { amazon.com } \\
\text { walmart.com } \\
\text { Az elmúlt } 3 \\
\text { hónapban } \\
\text { minimum } 3 \\
\text { alkalommal } \\
\text { vásárlók. } \\
\end{array}$ & $\begin{array}{l}\text { Minőség } \\
\text { Észlelt érték } \\
\text { Lojalitási } \\
\text { szándék }\end{array}$ \\
\hline $\begin{array}{l}\text { e- } \\
\text { TRANSQUAL }\end{array}$ & Bauer et al. & & $5 / 25$ & $\begin{array}{l}\text { 1. Funkcionalitás/design ( } 7 \text { elem) } \\
\text { 2. Élvezet (4 elem) } \\
\text { 3. Folyamat }(4 \text { elem }) \\
\text { 4. Megbízhatóság }(6 \text { elem) } \\
\text { 5. Válaszadó készség }(4 \text { elem) }\end{array}$ & $\begin{array}{l}\alpha=0,89 \\
\alpha=0,84 \\
\alpha=0,88 \\
\alpha=0,83 \\
\alpha=0,85\end{array}$ & $\begin{array}{l}\text { Journal of Business } \\
\text { Research }\end{array}$ & 384 & német panel & \begin{tabular}{|l|} 
Minőség \\
Észlelt érték \\
Elégedettség \\
Kapcsolat \\
tartóssága \\
Újravásárlási \\
szándék
\end{tabular} \\
\hline
\end{tabular}




\begin{tabular}{|c|c|c|c|c|c|c|c|c|c|}
\hline e-A-S-QUAL & Kim et al. & 2006 & 9 & $\begin{array}{l}\text { 1. Hatékonyság } \\
\text { 2. Megbízhatóság, teljesítés } \\
\text { 3. Rendszerelérhetőség } \\
\text { 4. Biztonság } \\
\text { 5. Válaszadó készség } \\
\text { 6. Kapcsolati lehetőség } \\
\text { 7. Információ minősége és mennyisége } \\
\text { 8. Személyre szabás } \\
\text { 9. Grafikai stílus }\end{array}$ & $\begin{array}{l}\text { Ez egy lista, } \\
\text { amivel } \\
\text { checkolni } \\
\text { tudják a cégek, } \\
\text { hogy mi van, mi } \\
\text { nincs ra } \\
\text { honlapon, ami } \\
\text { kell a jó } \\
\text { minöséghez }\end{array}$ & $\begin{array}{c}\text { Managing Service } \\
\text { Quality }\end{array}$ & & $\begin{array}{l}111 \text { női dolgot } \\
\text { árusító honlap }\end{array}$ & \\
\hline \multirow{4}{*}{ RECIPE } & \multirow{4}{*}{ Francis } & \multirow{4}{*}{2009} & $4 / 19$ & $\begin{array}{l}\text { 1. Honlapminőség ( } 4 \text { elem) } \\
\text { 2. Csere: fizetés és kézhezvétel ( } 5 \text { elem }) \\
\text { 3. Ügyfélszolgálat }(6 \text { elem }) \\
\text { 4. Biztonság }(4 \text { elem })\end{array}$ & $\begin{array}{l}\alpha=0,79 \\
\alpha=0,88 \\
\alpha=0,93 \\
\alpha=0,91\end{array}$ & \multirow{4}{*}{$\begin{array}{l}\text { Journal of Services } \\
\text { Marketing }\end{array}$} & \multirow{4}{*}{315} & \multirow{4}{*}{$\begin{array}{c}\text { ausztrál } \\
\text { vásárlók, a } \\
\text { népességhez } \\
\text { hasonló kor, } \\
\text { nem, } \\
\text { jövedelem, } \\
\text { lakhely szerinti } \\
\text { megoszlásban }\end{array}$} & Lojalitás \\
\hline & & & $4 / 18$ & $\begin{array}{l}\text { 1. Honlapminőség }(4 \text { elem }) \\
\text { 2. Foglalás/vásárlás }(5 \text { elem }) \\
\text { 3. Ügyfélszolgálat }(5 \text { elem }) \\
\text { 4. Biztonság }(4 \text { elem })\end{array}$ & $\begin{array}{l}\alpha=0,77 \\
\alpha=0,88 \\
\alpha=0,91 \\
\alpha=0,91\end{array}$ & & & & Lojalitás \\
\hline & & & $4 / 19$ & $\begin{array}{l}\text { 1. Honlapminőség (4 elem) } \\
\text { 2. Termékrészletek }(6 \text { elem }) \\
\text { 3. Ügyfélszolgálat }(5 \text { elem }) \\
\text { 4. Biztonság }(4 \text { elem })\end{array}$ & $\begin{array}{l}\alpha=0,70 \\
\alpha=0,88 \\
\alpha=0,95 \\
\alpha=0,86\end{array}$ & & & & Lojalitás \\
\hline & & & $4 / 20$ & $\begin{array}{l}\text { 1. Tranzakciós rendszer (4 elem) } \\
\text { 2. Felhasználói fiók kezelése }(6 \text { elem }) \\
\text { 3. Ügyfélszolgálat }(6 \text { elem }) \\
\text { 4. Biztonság }(4 \text { elem }) \\
\end{array}$ & $\begin{array}{l}\alpha=0,88 \\
\alpha=0,92 \\
\alpha=0,92 \\
\alpha=0,89\end{array}$ & & & & Lojalitás \\
\hline $\begin{array}{l}\text { E-S-Qual és } \\
\text { E-RecS-Qual } \\
\text { Bank }\end{array}$ & Akinci et al. & 2010 & $7 / 14$ & $\begin{array}{l}\text { 1. Hatékonyság }(2 \text { elem }) \\
\text { 2. Megbízhatóság, teljesítés }(2 \text { elem }) \\
\text { 3. Rendszerelérhetöség ( } 2 \text { elem }) \\
\text { 4. Biztonság }(2 \text { elem }) \\
\text { 5. Válaszadó készség }(3 \text { elem }) \\
\text { 6. Kompenzáció }(2 \text { elem }) \\
\text { 7. Kapcsolati lehetőség }(2 \text { elem })\end{array}$ & $\begin{array}{l}\alpha=0,84 \\
\alpha=0,84 \\
\alpha=0,87 \\
\alpha=0,87 \\
\alpha=0,83 \\
\alpha=0,83 \\
\alpha=0,83\end{array}$ & $\begin{array}{l}\text { Journal of Business } \\
\text { Research }\end{array}$ & $\begin{array}{l}2017 \\
(338)\end{array}$ & $\begin{array}{l}13 \text { török bank } \\
\text { ügyfelei }\end{array}$ & $\begin{array}{l}\text { Észlelt érték } \\
\text { Lojalitás }\end{array}$ \\
\hline
\end{tabular}

6. táblázat: A megvizsgált elektronikus szolgáltatásminőség skálák összefoglalója

Forrás: szakirodalom alapján saját készités 


\subsection{A fogyasztói elégedettség}

A vállalatok számára a vevői elégedettség stratégiai jelentőséggel bír, mivel a lojalitáshoz kapcsolódó szerepe miatt hozzájárul az eredményességhez (Kenesei - Kolos, 2007). A legtöbb kutató egyetért abban, hogy az elégedettség előzménye a minőség (Chang et al., 2009), azonban a köztük levő kapcsolat megragadására egységes álláspont nincs a szakirodalomban. Egyes tanulmányok a szoros rokonság miatt a teljes témakört a minőség címszó alatt, egyben tárgyalják (Hofmeister-Tóth et al., 2003).

Az elégedettség kutatása az emberi viselkedés megértésének egyik központi kérdése. Az elégedettség a szociológiában a társadalmi jólétet jelenti (social well-being), míg a pszichológiában az egyén érzelmi állapotát jelöli (Nirmalya et al., 2012). A marketing területén eredetileg a tranzakcióorientált fogyasztói elégedettség kutatása volt a jellemző (Johnson et al., 2000; Ltifi - Gharbi, 2012a), melynek során egy konkrét termékkel/szolgáltatással, szolgáltatóval való találkozás teljesítményét értékelik, azonban a későbbiekben a több tranzakció után kialakult, ún. kumulált elégedettségről is számos kutatás született (Johnson - Fornell, 1991; Chang et al., 2009). Ez utóbbi a pszichológiai és közgazdasági megközelítéshez hasonló, ahol az elégedettség a fogyasztás hasznát jelöli, valamint jobban képes a viselkedést és gazdasági teljesítményt előre jelezni (Johnson et al., 2000).

\subsubsection{Az elektronikus szolgáltatásminőség és az elégedettség kapcsolata}

Az észlelt minőség és az elégedettség kapcsolatát (de Ruyteret al., 1997), valamint az érzelmek szerepét a fogyasztói elégedettség kialakulásánál sokan kutatták (Oliver, 1993). Hunt (1977) az attitüdöt elkülöníti az elégedettségtől, mivel az attitűd egy érzés, pl. élvezet, míg az elégedettség az érzelmek evolúciója. Ezzel szemben Oliver (1980, 1981) az elégedettséget múló tapasztalati érzelemként értelmezi, és szerinte az attitűd sokkal tartósabb érzés. Ajzen és Fishbein (1972) definíciója szerint az attitüd egy kedveltségi kontinuumban mutatja meg az adott tárgy helyét.

Veres (1999) szerint az elégedettséget a szolgáltatás minőségéről alkotott fogyasztói értékítélet alapján lehet mérni. Mások szerint a teljes elégedettség az észlelt szolgáltatásminőség elsődleges következménye (Parasuraman et al., 1988; Cronin, 1994; Chang, 2005; Ribbink et al., 2004). Online környezetben Wolfinbarger és Gilly (2003) végeztek kutatást a témában, melynek eredménye alapján megállapítható, hogy az eszolgáltatásminőség dimenziói pozitív kapcsolatban állnak az elégedettséggel, mely 
hipotézist Bressoles és társai (2007) is alátámasztották. Yang és tsai. (2007) kutatása bizonyítja, hogy az egyik leggyakrabban alkalmazott elektronikus szolgáltatásminőség skála, az E-S-Qual, illetve E-RecS-Qual dimenziói együttesen és külön-külön is pozitívan befolyásolják a fogyasztói elégedettséget. Godwin és társainak (2010) eredményei szintén azt mutatják, hogy az elégedettséget az észlelt minőség részben befolyásolja. Úgy gondoljuk, ezeknek az eredményeknek a tükrében elfogadható az a feltételezés, hogy az észlelt minőség és a fogyasztói elégedettség között pozitív kapcsolat áll fenn.

Az elégedettség egy érzelmi állapot, mely a negatív, illetve pozitív elvárások és élmények tükrében alakul ki (Oliver, 1980). Hasonló Parasuraman és társainak definíciója is (1994), mely szerint az elégedettség megmutatja, hogy az egyéni elvárásokhoz képest a teljesítmény hogyan alakult (Chen - Cheng, 2012). Rust és Oliver (1994, in: Chang et al., 2009) megfogalmazásában az elégedettség annak a foka, hogy a fogyasztó mennyire hisz abban, hogy valaminek a birtoklása vagy használata pozitív érzéseket kelthet benne. Oliver (1997) szerint mivel a fogyasztás valamilyen célt, vágyat elégít ki, ezért fontos, hogy azt kellemesnek érezzék. Az elégedettség ennek a kellemes teljesülésnek az érzete (Oliver, 1999).

Véleményünk szerint az elégedettség mivoltát a Stauss és Seidel (1995) által megalkotott definíció foglalja össze legjobban, mely szerint ,fogyasztói elégedettség alatt a vásárlás után fellépö olyan jelenséget értjük, melyben visszatükröződik, hogy a fogyasztó utólag hogyan értékeli a megvásárolt terméket, szolgáltatást. Az elégedettség ex-post értékelésből származik, továbbá feltételezi a személyes fogyasztás, illetve vásárlási élmény meglétét." (in: Hofmeister-Tóth et al., 2003)

Hasonlóan a korábbi megfogalmazásokhoz, az e-elégedettség online környezetben is a fogyasztói élmény értékelését jelenti az adott webshoppal kapcsolatban, a korábbi online vásárlási tapasztalatokat figyelembe véve (Anderson - Srinivasan, 2003). Az ekereskedelem esetében, amikor csak egyszer használja valaki az adott webshopot, pl. foglal egy szobát, akkor tranzakciós elégedettségröl beszélünk, míg többszöri, ismételt vásárlás esetén kumuláltról.

Az információs rendszerek irodalmában, mely szintén jelentős az e-kereskedelem esetében, az elégedettség a vélemények összessége egy rendszer attribútumairól a hatékonyságra koncentrálva, amelynek fő elemei a design és az implementációs tevékenységek. Az elégedettséget tehát az információ tartalma, a személyre szabott 
szolgáltatások, a felhasználói felület, illetve a rendszerértékek dimenziói határozzák meg (Lu et al., 2012).

\subsubsection{Az elégedettségmérés módszerei}

Az elégedettség mérésének két jelentős módszertanát különböztetjük meg: a szubjektív módszereket, valamint az objektíveket. Az utóbbiak esetében valamilyen objektíven mérhető mutatószámmal - például piaci részesedés, elpártolás mértéke, újravásárlási ráta -, közvetve mérik az elégedettség szintjét. Ezzel szemben a szubjektív módszerek a vevői észlelésre alapoznak (Hoffmeister-Tóth et al., 2002; Kenesei - Kolos, 2007).

A szubjektív eljárások esetében három metódust különböztetünk meg: a jellemzőorientáltat, az eseményorientáltat, illetve a problémaorientáltat (9. ábra). A jellemzőorientált implicit módszerek esetében nem kérdezik meg a fogyasztókat közvetlenül, hanem a munkatársak megkérdezésével, vagy próbavásárlások alapján mérik fel az elégedettséget. Ezzel szemben az explicit módszerek használatakor a fogyasztók direkt megkérdezése a jellemző, melynek egyik csoportját alkotják a többtényezős mérési módszerek. Ezek lényege, hogy a minőség a teljesítményjellemzők globális megítélése. A beállítódásorientált mérés esetében a fogyasztói megítélést, illetve annak súlyát vesszük figyelembe a vevői értékelésnél, míg az elégedettségorientált mérés esetében a diszkonfirmációs paradigma alapján mérjük az elégedettséget (Hoffmeister-Tóth et al., 2002).

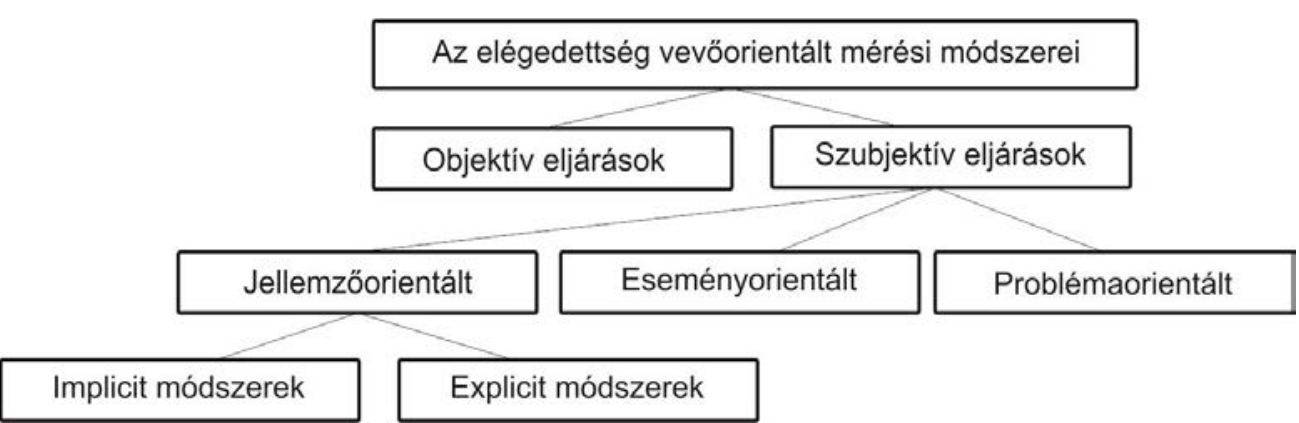

\section{9. ábra: Vevőorientált mérési módszerek az elégedettség esetében}

Forrás: Hofmeister-Tóth et al. (2003)

Ahogy azt a leírtak is mutatják, az elégedettség meghatározása komplex feladat. A szakirodalomban az egyik legtöbbet alkalmazott megközelítés a diszkonfirmációs paradigma (Oliver, 1980; Szymanski - Henard, 2001; Hoffmeister-Tóth et al., 2002), melynek értelmében az elégedettség annak a foka, hogy a fogyasztói elvárások mennyire teljesülnek (Oliver, 1999; Westbrook - Oliver, 1991; Parasuraman et al., 1991, Józsa - 
Ercsey, 2005). Az elvárások mint standard jelennek meg, és ezek alapján ítélik meg a teljesítményt. Ha az aktuális outcome felülmúlja az elvárásokat, akkor a fogyasztók elégedettek (pozitív diszkonfirmáció), ha az elvárások magasabbak, akkor elégedetlenek (negatív diszkonfirmáció), és ha pont megegyezik a kettő (zéró vagy egyszerü diszkonfirmáció), akkor egy semleges állapot alakul ki (Oliver 1981; Oliver - DeSarbo, 1988; Szymanski - Henard, 2001).

Fournier és Mick (1999) ezt a koncepciót a termék fontosságával egészíti ki, tehát:

$$
\text { Elégedettség }=(\text { Teljesítmény }- \text { Elvárás }) * \text { Fontosság }
$$

Elméletüket azonban empirikusan még nem támasztották alá.

Ezzel szemben a szociális méltányosság elmélete szerint (Woodruff et al., 1983) a fogyasztói érzékelést a megszerzés költsége (pénz, erőfeszítés) és a kapott teljesítmény aránya befolyásolja, melyet egy másik ember (eladó, barát) arányával hasonlítanak össze. A méltányosság foka azt jelenti, hogy mit észlel a fogyasztó azzal kapcsolatban, amit ő elért, illetve mások elértek. Amennyiben a saját output és input aránya magasabb, mint a másoknál észlelt arány, akkor elégedettség alakul ki (Goodwin - Ross, 1992; Oliver Rust, 1997; Szymanski - Henard, 2001).

$$
\begin{aligned}
& \mathrm{O}_{\mathrm{c}} / \mathrm{I}_{\mathrm{c}} \text { ? } \mathrm{O}_{\mathrm{r}} / \mathrm{I}_{\mathrm{r}} \\
& \mathrm{C} \text { - fogyasztó } \\
& \mathrm{R} \text { - referenciacsoport }
\end{aligned}
$$

A teljesítmény-elégedettség paradigma a diszkonfirmációs megközelítés része, azonban ez alapján a teljesítmény elégedettségre gyakorolt hatását direkt mérik (Churchill Surprenant, 1982; Oliver - DeSarbo, 1988; Tse - Wilton, 1988). A paradigma az értékészlelés különbözőségére alapul.

A vásárlás utáni interakció paradigmát (post purchase interaction paradigm) követök szerint az elégedettség inkább a vásárlás utáni folyamat, mintsem mentális állapot. Véleményük szerint az elvárás és a teljesítmény közötti különbség a vásárlás után stresszérzetet alakít ki a vásárlóban, melynek csökkentése a cél. Ha ez lecsökkent, az elégedettségértékelési folyamat véget ér. A stressz csökkentésére belső és külső faktorok hathatnak. Az elégedetlen vevő például elmondja másnak az érzéseit (negatív WOM) ez külső stresszcsökkentést jelent -, de dönthet úgy is, hogy legközelebb nem az adott terméket vagy szolgáltatást veszi meg - belső stresszcsökkentés (Nirmalya et al, 2012). 
Kutatásunk során az elégedettségmérési koncepciók közül az explicit, többtényezős módszerek közé tartozó diszkonfirmációs paradigmát alkalmazzuk, mivel ez az egyik legelterjedtebb koncepció, valamint Szymanski és Henard metaanalízise alapján (2001) a legerősebb korrelációt az elégedettséggel a méltányosság, illetve a diszkonfirmáció elméletei mutatnak.

\subsubsection{Az elégedettség mérése a diszkonfirmációs paradigmával}

A fogyasztók jövőbeli viselkedését (elégedettség, újravásárlás, továbbajánlás, lojalitás stb.) a vásárlási előtti, alatti és utáni faktorok is befolyásolják (Minocha et al., 2005). Az elégedettség kialakulásával kapcsolatban a diszkonfirmációs paradigma központi helyet foglal el (Hoffmeister-Tóth et al., 2002), ahol az elégedettség/nem elégedettség az elvárások és a teljesítmény összehasonlítása alapján alakul ki. Amennyiben elfogadjuk, hogy az elégedettség a teljesítmény teljes értékelését jelenti, akkor a minőség az elégedettség előzménye (Johnson et al., 1995), tehát az elégedettség meghatározható a minőségdimenziók elvárt és tapasztalt értékeinek mérésével.

Az elvárások a korábbi használat, a kommunikáció, illetve a vásárlás során alakulnak ki, és ezek szolgálnak a teljesítmény mércéjeként. Az elvárások és a teljesítmény megegyezése konfirmációt jelent, túlteljesítése pozitív, míg alulteljesítése negatív diszkonfirmációt eredményez, és ezek vezetnek az érzelmi reakcióhoz, melyet elégedettségnek vagy elégedetlenségnek nevezünk (Oliver, 1980; Szymanski - Henard, 2001).

Az elégedettség okainak és hatásainak megértése már a '60-as évek óta kiemelt kutatási terület (Day, 1977; La-Tour - Peat, 1979; Oliver, 1977). Az első tanulmányok két tényezőt jelöltek meg, mely szerepet játszik az elégedettség kialakulásában: a teljesítményspecifikus elvárásokat, illetve a a várakozások megerősítésének elmaradását (expectancy disconfirmation). A meg nem erősítés elmélete körül sok kutatás született (Oliver, 1980). A 70-es évektől kezdve laboratóriumi körülmények közötti vizsgálattal (Anderson, 1973; Cohen - Goldberg, 1970; Olshavsky - Miller, 1972; Oliver, 1980), illetve longitudinális elemzések útján is foglalkoztak már vele (Oliver, 1977, 1980). Az eredmények alapján mindenki egyetért azzal, hogy a vásárlás utólagos értékelése az elvárások alapján történik, és az egyén elvárása egy termékkel/szolgáltatással kapcsolatban egyfajta adaptációs szintként értelmezhető. 
Helson (1948) adaptációs elmélete szerint egy új stimulus értékelése a korábbi tapasztalatok alapján történik. Az adaptációs szint kialakulása (Oliver, 1980) három dologtól függ: (1) a termék maga is tartalmaz korábbi tapasztalatot, szimbolikus elemeket, (2) az adott szituáció, melyben az eladóval való kommunikáció és a társadalmi referenciák megjelennek, (3) illetve az egyén jellemzői. A stimulus értékelését a determinált és az új stimulus közötti különbség határozza meg, és az elégedettség az elvárt és a kapott teljesítmény közti különbség alapján alakul ki (Oliver - Linda, 1981).

Day (1977) szerint az elvárások, amelyek szerepet játszanak az értékelési folyamatban, három csoportba sorolhatók:

1. elvárások a termék/szolgáltatás teljesítményével kapcsolatban;

2. az elvárt költségek és az erőfeszítések;

3. indirekt költségek és előnyök.

A termékkel/szolgáltatásokkal kapcsolatos elvárások az azonos vagy hasonló termék/szolgáltatás korábbi használatából származnak. Ez egyfajta tanulási folyamat, mely a kiemelten fontos jellemzők szintjéből, ezek fontosságából és az elvárások hármasából áll. A sokat tapasztalt fogyasztónak jelentősebb elvárásai lesznek, míg a kevésbé tapasztaltnak vagy tapasztalatlannak alacsonyabbak. Ök a reklámban, az eladóban, és mások tapasztalataiban bíznak, és erre alapoznak. Ezek az elvárások azonban kevésbé stabilak: nagyobb valószínűséggel lesz elégedetlen az egyén, ha a tapasztalatlansága miatt nem megfelelő terméket választ. Az elvárásokat személyes és szituációs tényezők is befolyásolják, és az így összességében kialakult elvárások döntik el többnyire a fogyasztói elégedettséget, illetve elégedetlenséget (Day, 1977).

Az elvárt költségekhez tartozik az ár, illetve az erőfeszítések, melyet egy termék/szolgáltatás által nyújtott előnyök elérésére fordít az egyén. Az elképzelt és tényleges ár közötti különbségnek számos hatása van. Sokszor az ár mint a minőség jelzője jelenik meg, és magas elvárásokat eredményez. A tapasztalt vevő az alacsonyabb árat jó alkuként értelmezi, a magasabbat túlzásként. A kevésbé tapasztalt fogyasztó a teljesítmény jellemzőjeként értelmezheti a magasabb árat, valamint az ár a vásárlás fontosságát is meghatározhatja: magasabb ár, nagyobb fontosságot jelent(het) (Day, 1977). 
A költségek oldalán jelenik meg az idő és az erőfeszítés is, amelyet egy vásárlás megkíván. Vannak, akik számos információt gyüjtenek a vásárlás előtt, és ezek a vásárlás fontosságát is tükrözik. Az alternatív költségek (opportunity cost) értelmezése, vagyis hogy miről mondunk le a vásárlásért cserébe, szintén befolyásolja az elégedettség alakulását.

Az indirekt költségek és előnyök, melyek közé a pszichológiai előnyök, illetve a másokra gyakorolt hatás tartoznak, szintén jelentős hatással bírnak. Ez főleg a státusztermékeknél jelentős. Ilyen szituációkban, illetve olyan termékek/szolgáltatások vásárlása esetén, amelyek fogyasztása másokkal, mások előtt történik, a vásárlás mások általi megerösítése vagy meg nem erősítése befolyásolja az elégedettséget; néha jobban, mint a saját értékelés. Ezek a szociális faktorok azonban a kereskedő által kevésbé befolyásolhatóak (Day, 1977).

Eleinte az elvárásokat kognitív szintként kezelték, azonban Oliver (1980) a kognitív és az affektív dimenziókat kombinálva magyarázza az elvárások alakulását. Az attitüdök (affektív dimenzió) formálódása Howard és Sheth (1969, 147. o., in: Oliver, 1980) véleménye szerint a következő képlettel írható le:

$$
\begin{aligned}
& A_{t+2}=f\left(S_{t+1}-A_{t}\right)+A_{t} \\
& A_{t}-\text { vásárlás előtti attitüd } \\
& S_{t+1}-\text { azonnali, vásárlás utáni elégedettség } \\
& A_{t+2}-\text { átgondolt vásárlás utáni attitüd }
\end{aligned}
$$

A zárójeles különbség a kognitív összehasonlítása az előre érzett elégedettségnek $\left(A_{t}\right)$ és a megkapott elégettségnek, tehát ebben az esetben a diszkonfirmáció egy absztrakt érzelmi szintet jelent.

Ha az elvárásokat mint hiteket (beliefs) kezeljük, akkor két dolgot kell figyelembe venni. A hitek az attitűdformálásban szerepet játszanak, valamint az elégedettség egy adaptációs szintjeként szolgálnak (Oliver 1980). Amennyiben elfogadjuk, hogy a hit = elvárás, akkor:

$$
\begin{aligned}
& \text { attitüd }\left(\mathrm{t}_{1}\right)=\mathrm{f}(\text { elvárások }) \\
& \text { elégedettség }=\mathrm{f}(\text { elvárások, diszkonfirmáció }) \\
& \text { attitüd }\left(\mathrm{t}_{2}\right)=\mathrm{f}\left(\operatorname{attitüd}\left(t_{1}\right) \text {, elégedettség }\right)
\end{aligned}
$$


Összegezve megállapítható, hogy a fogyasztói elvárásokat, melyek az összehasonlítás alapjául szolgálnak, jelentős számú tényező befolyásolja. A fogyasztó saját belső információi közül a korábbi használat során észlelt minőség és tapasztalatok, illetve a szükségletek jelentősek, míg a külső információforrások közül a másoktól hallottak, a szájreklám, valamint a vállalat saját kommunikációja kiemelt (Hill 1986; HofmeisterTóth et al., 2003). Az összehasonlítás másik oldalát a tapaszalt teljesítmény jelenti, mely a különböző észlelt minőségdimenziók aktuális értékeléséből adódik (Hill 1986) (10. ábra).

A pozitív, a negatív vagy a zéró diszkonfirmáció annak függvényében alakul ki, hogy a termék/szolgáltatás teljesítménye mennyire esik egybe az elvárásokkal (Oliver - Linda, 1981). Az elégedettség tehát úgy értelmezhető, mint az elvárások és a diszkonfirmáció szintjének a kombinációja, mely a fogyasztói elégedettség szintjén is értelmezhető (Olshavsky - Miller, 1972; Olson - Dover, 1976; Oliver, 1980). Howard és Sheth modellje (in: Oliver, 1980) szerint a kialakult elégedettség befolyásolja a jövőbeli vásárlási szándékot is:

$$
\begin{aligned}
& \text { szándék }\left(\mathrm{t}_{1}\right)=\mathrm{f}\left(\operatorname{attitüd}\left(\mathrm{t}_{1}\right)\right) \\
& \text { szándék }\left(\mathrm{t}_{2}\right)=\mathrm{f}\left(\operatorname{szándék}\left(\mathrm{t}_{1}\right), \text { elégedettség, attitüd }\left(t_{2}\right)\right)
\end{aligned}
$$

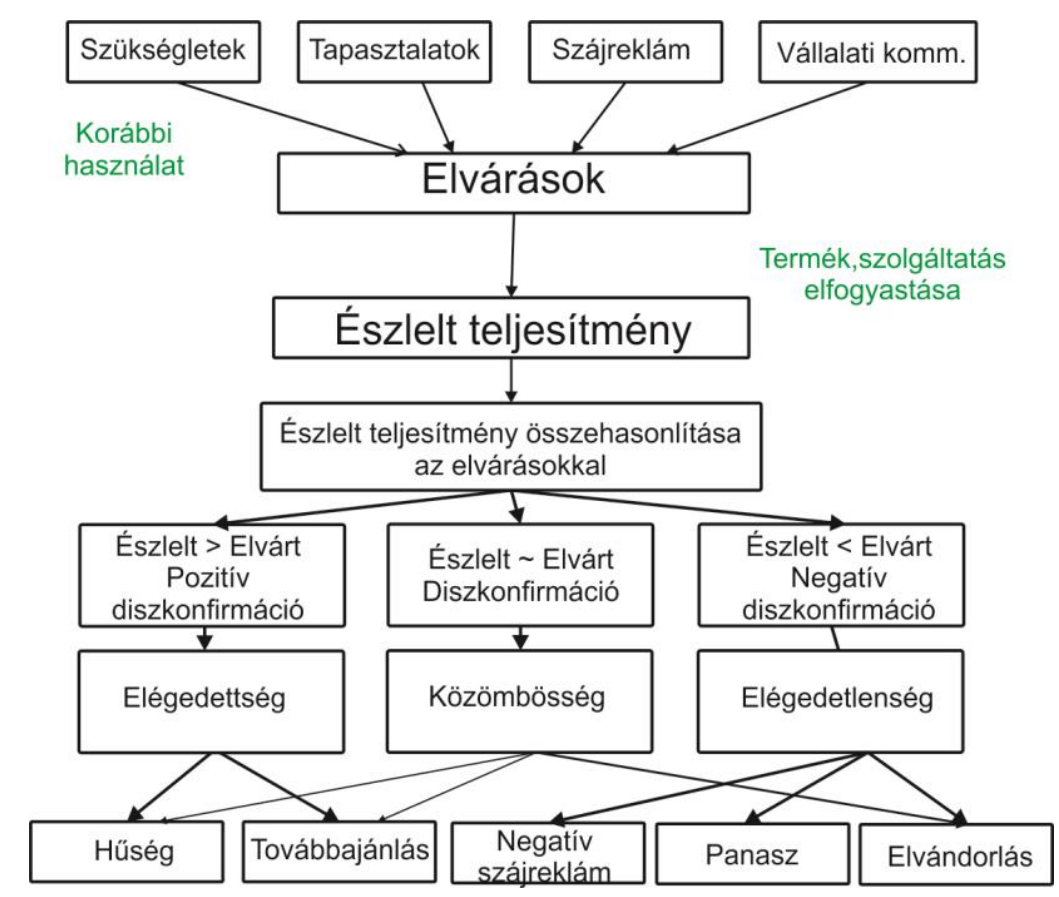

10. ábra: A pozitív, a negatív és a zéró diszkonfirmáció kialakulása és következménye

Forrás: Hoffmeister-Tóth et al. (2003) és Hill (1986) alapján saját szerkesztés 
Azt, hogy mely esetekben beszélünk konfirmációról, illetve diszkonfirmációról, egy további tényező, az úgynevezett toleranciazóna is befolyásolja (zone of indifference) (11. ábra), melynek kiterjedtsége egyénenként és szituációnként is változhat (Woodruff et al., 1983; Hill, 1986). Ha a tényleges teljesítmény alacsonyabb vagy magasabb, mint az elvárt, de ez a különbség a zónán belülre esik, konfirmációról beszélünk. Csak akkor alakul ki pozitív vagy negatív diszkonfirmáció, ha a különbség ezen a zónán kívülre esik. A konfirmáció nem vált ki különösebb, figyelemfelkeltő cselekvést, míg a diszkonfirmáció valamilyen viselkedésre késztet: attitűdváltozás, változás az újrahasználati szándékban, szájreklám, panaszkodás stb. (Day 1977, 1982; Oliver, 1980, 1981). A pozitív diszkonfirmáció erősítheti az attitüdöt vagy az újrahasználati szándékot (Oliver, 1980), eredményezheti a normák változását, illetve lojalitáshoz vezethet, míg a negatív diszkonfirmáció esetében a negatív szájreklám (Richins, 1983; Hill, 1986) a jellemző.

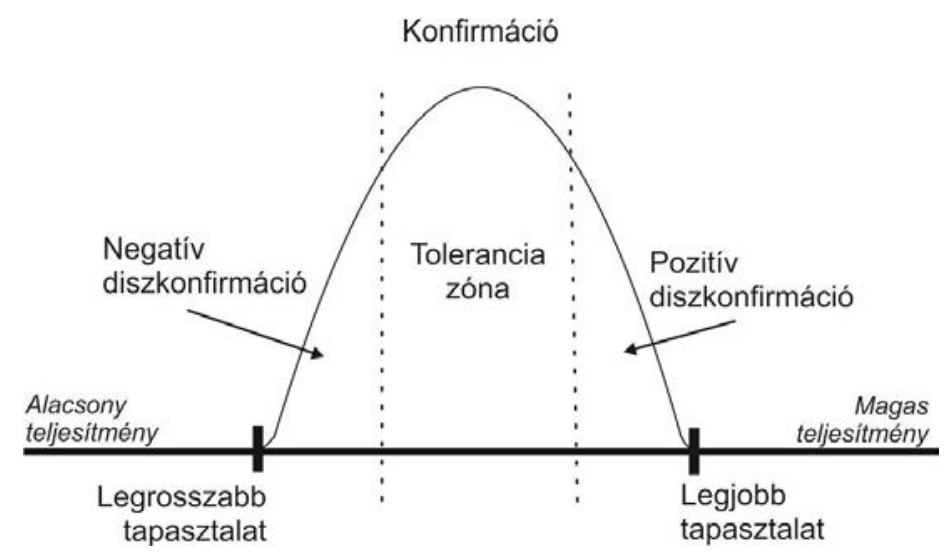

\section{1. ábra: Toleranciazóna}

Forrás: Woodruff, Cadotte, Jenkins (1983)

Mivel az internetes vásárlás is egyre elterjedtebb, a fogyasztók számos tapasztalattal rendelkeznek, és széles körben használták már az online vásárlást, ezért ez a paradigma itt is jól használható (Qin, 2007). A diszkonfirmációs elmélet alkalmazásának köszönhetően a vállalatok képesek megismerni tényleges teljesítményüket, a fogyasztók igényeit és elvárásait, valamint egy standardot nyújt számukra a jövőbeli fejlesztésekhez (Fearon - Philip, 2008). Ez utóbbi tény szintén befolyásolt abban, hogy kutatásunk során ezt az elégedettségkoncepciót alkalmazzuk. 


\subsubsection{Elégedettségindexek}

Az elégedettségkutatás során indexek megalkotása is jellemző, melyek használata a menedzserek számára lehetőséget biztosít, hogy vállalatuk teljesítményét a fogyasztói észlelés alapján értékeljék, és a fejlesztendő területeket így könnyebb fel tudják fedni (Hoffmeister-Tóth et al., 2002; Carlson - O'Cass, 2011).

Az első fogyasztói elégedettségindexet (SCSB) Svédországban alkották meg 1989-ben. A modell az elvárt és az észlelt teljesítményt méri. Az észlelt teljesítmény ebben az esetben az észlelt értéknek és minőségnek felel meg, vagyis annak, amit a befektetett költségekért kapott az egyén. Az elvárás inkább egy „lesz elvárás”, mintsem egy normaérték (,kellene, hogy legyen”).

Az index megalkotásakor a „kilépés-felszólalás” (exit-voice) elméletet (Hirschman et al. 1982) vették figyelembe, mely szerint ha az egyén elégedetlen, akkor kilép, vagy hangot ad ennek, tehát panaszkodik. Az elégedettség növelése csökkenti a panaszkodást, illetve növeli a lojalitást, amely a modell független változója (12. ábra). A modell tartalmazza a panaszkodási magatartás hatását a lojalitásra, mely komponens információt nyújt a vállalat ügyfélszolgálatáról és panaszkezeléséről (Fornell, 1992). Amennyiben ez a kapcsolat pozitív, akkor lojalitás alakítható ki, ha negatív, akkor az egyén otthagyja a vállalatot.

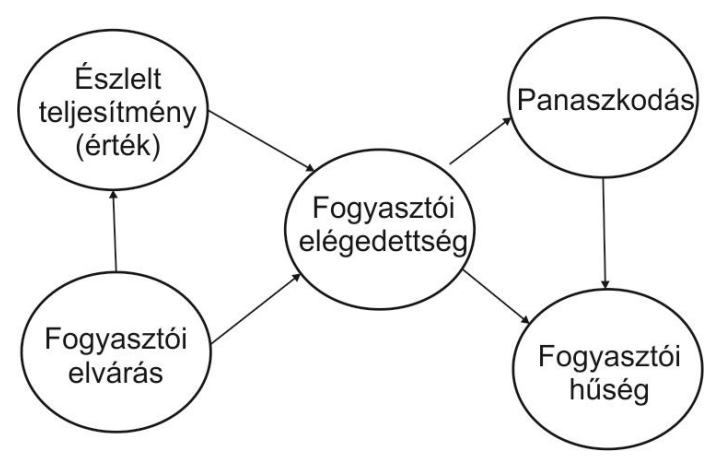

\section{2. ábra: Fogyasztói elégedettségindex (SCSB)}

Forrás: Johnson et al. (2000)

Ezzel szemben az amerikai fogyasztói elégedettségindex (ACSI) az észlelt minőség és az érték fogalmát már külön kezeli (13. ábra). A modell értelmében mindkettő növeli az elégedettséget. Az elvárások dimenzió itt már tartalmazza az elvárt személyre szabást és a megbízhatóságot is. A lojalitás mérése is különbözik a svéd indextől, ugyanis két módon mérik: az újravásárlás valószínűségével, illetve azzal, hogy a vállalat mennyire tudja az 
árat növelni vagy csökkenteni úgy, hogy még mindig öt válasszák a versenytársakkal szemben (Johnson et al., 2000).

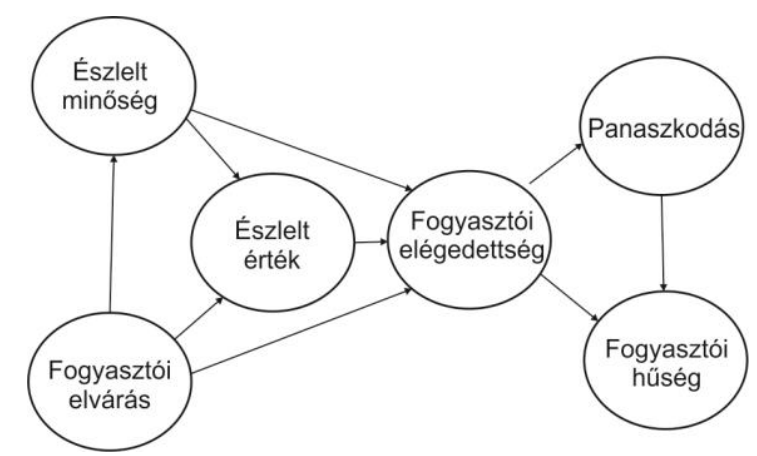

\section{3. ábra: Fogyasztói elégedettség index (ACSI), USA}

Forrás: Johnson et al. (2000)

A korábban kialakított fogyasztói indexek gyengeségeit figyelembe véve Johnsonék 2000-ben létrehoztak egy újfajta fogyasztói elégedettségindexet. Mivel a kiinduló elvárásokat a legtöbb kutatás esetében többnyire akkor gyüjtik be, amikor már túlvannak a vásárláson, ezért ezt a tényezőt ők kihagyták, és inkább a vállalati hírnevet tették bele a modellbe. A panaszkodási viselkedés helyett is inkább a panaszkezelés módját mérik a modellben, mert véleményük szerint ez sokkal inkább összefügg az elégedettséggel (14. ábra).

Véleményük szerint a minőség és az érték összefüggő koncepciók, ezért az értéket egy árkomponenssel helyettesítették, és az egész modellt kiegészítették az ár és a minőség direkt hatásával a lojalitásra. A koncepciójuk szerint az elégedettség mediálja a minőség és az ár kapcsolatát a lojalitással (Johnson et al., 2000).

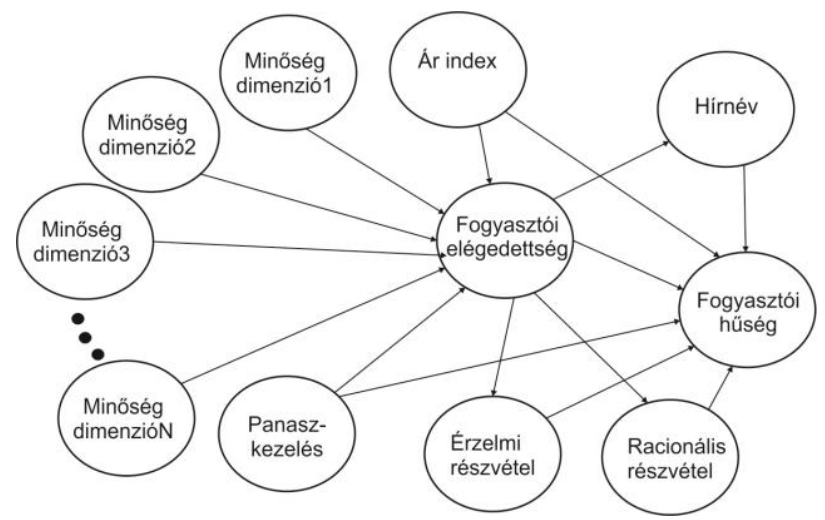

14. ábra: Fogyasztói elégedettségindex (NSBI)

Forrás: Johnson et al. (2000) 
Ezeket az indexeket figyelembe véve a disszertáció során megalkotott koncepciót felhasználva is létrehozható egy index, mely segíti az elektronikus kereskedelemmel foglalkozókat, hogy a fogyasztói minőségészlelést és a hiányosságokat pontosan értelmezni tudják, és ezáltal longitudinális vizsgálatokat végezve a vállalat fejlődősét is követhessék.

\subsection{Az elégedettség következményei}

Az elégedettség szintje és mértéke jelentős következményeket von maga után. Disszonancia, vagyis nem elégedettség esetén a fogyasztók fejében felmerülő első kérdés, hogy elhagyják-e a céget, vagy maradjanak, míg panaszkodáshoz általában a fokozott elégedetlenség vezet (Folkes, 1984; Richins, 1983; Ursic, 1985; Szymanski - Henard, 2001). A negatív szájreklám (WOM) a panaszkodás egy fajtája, amelyet szintén az elégedetlenség idéz elő (Folkes, 1984; Richins, 1983). Ilyenkor nem a vállalatnak, hanem a jövőbeli vásárlóknak mondják el sérelmüket a fogyasztók. Minél jellemzőbb a panaszkodás, illetve a negatív szájreklám, annál inkább csökken az adott üzlet újraválasztási valószínűsége, valamint gyengül az újravásárlási szándék. Emellett az elégedetlen fogyasztók hajlandóbbak további információkat keresni, és könnyebben csábulnak el a versenytársak ajánlatai láttán.

Ezzel szemben az elégedettség számos pozitív, jövedelmező hatást hordoz egy vállalat számára (15. ábra). Az elégedett vevő újravásárlásai során visszatér a vállalathoz, illetve jó hírét viszi a cégnek (Dodds et al., 1991; Oliver, 1997; Parasuraman - Grewal, 2000; Szymanski - Henard, 2001; Chang et al., 2009). A pozitív szájreklámmal támogatja az új vásárlók megszerzését, ezzel csökkentve a vevőszerzés költségét. Az elégedett vásárlók jellemzően megbocsátóbbak a szolgáltatók hibáival szemben, és érzéketlenebbek a konkurencia ajánlataira, tehát a vállalat versenyelőnyét erősítik (Zeithaml et al., 1996; Kenesei - Kolos, 2007), hosszú távon pedig lojálissá tehetők (Cronin - Taylor, 1992; Oliver, 1999; van Riel et al., 2004). Igaz, hogy az elégedettség és a hűség között bonyolult kapcsolati viszony áll fenn, azonban megfelelő stratégia mellett a vevők többsége lojálisság tehető (Hofmeister-Tóth et al., 2003). 


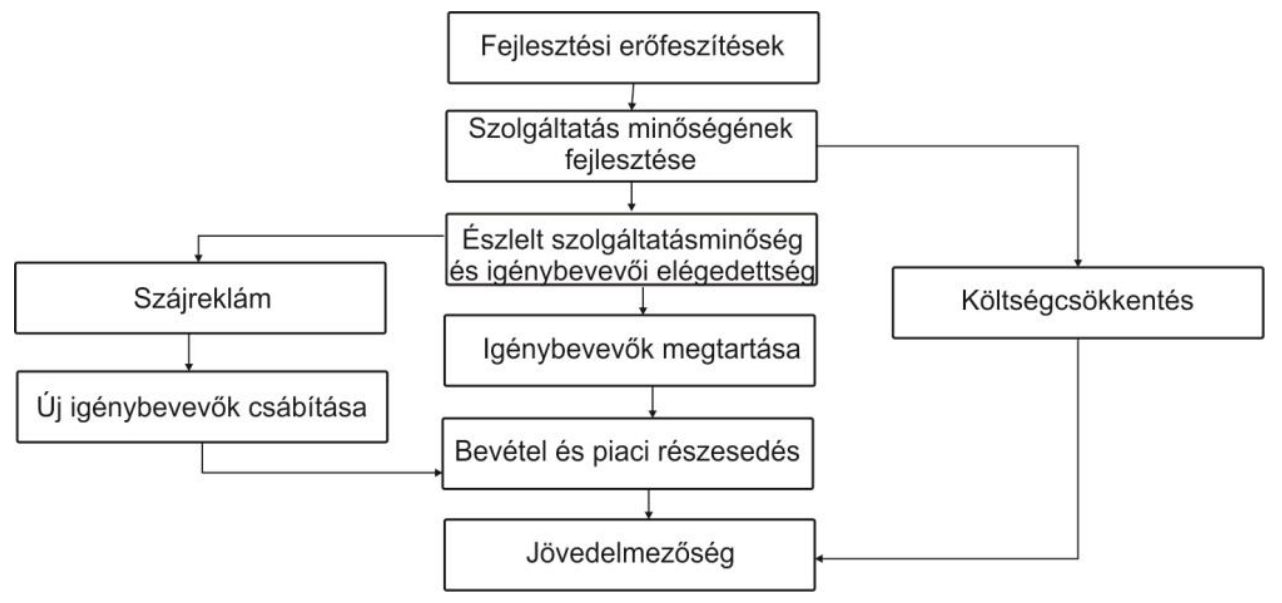

\section{5. ábra: A szolgáltatásminőség és a szájreklám kapcsolata}

Forrás: Veres (2009), 99. old

Kutatások bizonyítják, hogy a lojális fogyasztók nem biztos, hogy a legelégedettebbek, és fordítva (Reichheld, 1994; Fornell, 1992; Oliver, 1999; Castaneda, 2011). Az egy adott terméket/szolgáltatást vagy vállalatot ismerő fogyasztókat elégedettségük alapján a következő csoportokba oszthatjuk:

(1) elégedetlen fogyasztó, aki nem elégedett a kapott termékkel/szolgáltatással, ezért új céget keres;

(2) semleges fogyasztó, aki azt a terméket, szolgáltatást veszi, amely éppen a legkönnyebben elérhető számára;

(3) elégedett fogyasztó, aki igaz, hogy elégedett a kapott termékkel, szolgáltatással, mégis nyitott az új lehetőségekre;

(4) lojális fogyasztó, aki a versenytársak ajánlatinak ellenére is visszatér a vállalathoz (Rekettye - Hetesi, 2009).

Online környezetben, ahol a csatorna sajátosságai miatt sokkal egyszerübb a versenytársak ajánlatait elérni, valamint alacsonyabbak a váltási költségek, nagyobb jelentőséggel bír az újralátogatás és újravásárlás szerepe, mely hosszú távon lojalitást eredményezhet (Vallejo et al., 2005). Ezért is tartjuk célravezetőnek megvizsgálni, hogy egy webáruház megadja-e azokat az elvárt minőségszinteket, illetve teljesítményt, amelyek a fogyasztók elégedettségéhez, ezen keresztül pedig pozitív viselkedéséhez vezetnek.

Az elégedettség alakulását és ennek következményeit több változó befolyásolhatja, úgymint a vásárló személyes jellemzői, a referencia szintje, az összehasonlító sztenderdek vagy a vásárolt javak tartós vagy nem tartós jellege (Churchill - Surprenant, 1982; 
Szymanski - Henard, 2001), illetve az, hogy termékről vagy szolgáltatásról van-e szó. Ez utóbbi oka, hogy a szolgáltatások számos tekintetben különböznek a termékektől romlandóság, megfoghatóság, fogyasztás és termelés elválaszthatatlansága, sztenderdizálás -, és emiatt másfajta elvárások alakulnak ki velük kapcsolatban (Parasuraman et al., 1985).

Az online vásárlásban egyeseket a pénz- és időspórolás, míg másokat a kényelmesség igénye vezérel. Jarvenpaa és Todd (1997) szerint ez utóbbi az online vásárlás egyik legnagyobb előnye. Burke (1997) úgy látja, hogy az internetes vásárlók kényelmesebbek, mint az interneten nem vásárolók. A személyes jellemzők közül Srinivasan és társai (2002) szerint az elégedettség következményeit befolyásolja az egyén kényelemorientáltsága: a kényelemorientált vevő kevésbé hajlandó új eladó után nézni.

Az információorientált vásárlók döntésük meghozatalához többet keresgélnek, és ezáltal jobb értékelést készítenek (Olsen, 2002). Shankar, Smith és Rangaswamy (2003) szerint minél több az elérhető információ, annál nagyobb kognitív erőt fektetnek a keresésbe, ami járulékos előnyt hozhat (pl. olcsóbb ár). Online környezetben az információk könnyebben és gyorsabban érhetők el, mint offline (Shankar et al., 2003), így az egyének sokkal jobb döntést képesek hozni, ami elégedettségüket is befolyásolja (Szymanski Hise, 2000). Feltételezzük, hogy az információkeresési hajlandóság nem csak az elégedettséget befolyásolja, hanem az elégedettség következményeinek alakulására is befolyással bír.

Online környezetben, ahol nagyszámú ajánlat érhető el könnyen, a változatosságkeresési vágy az elégedettség következményeire jelentős hatással lehet. Kutatások bizonyítják, hogy a változatos kínálat nagyobb elégedettséget eredményez (Agárdi, 2004), azonban Oliver (1999) szerint a változatosságkeresési vágy negatív hatással bír a lojalitásra, amely tény alapján feltételezzük, hogy az újravásárlási szándékra és a szájreklámra is.

A nem személyes jellemzők közül a vásárlás pénzben kifejezett értéke is hatással van az elégedettség következményeire. Kuehn (1962) és Day (1969) szerint a nagy összegért vásárlók sokkal inkább lojálisak. Ök általában érzelmek által motiváltak: a sokat költők személyesen sokkal inkább érdekeltek a döntéshozatalban, ezért az elégedettség hatása is nagyobb a lojalitásukra (Kim et al., 1997).

A lojalitás folyamatos kapcsolat egy fogyasztó és egy márka között, mely érzelmi kapcsolat a fogyasztót az adott céghez/márkához köti vásárlásai során (Ltifi - Gharbi, 
2012a). Mills (1998) szerint is a hüség nem egy állapot, hanem egy állandó kapcsolat. A kapcsolati folyamat fejlödése során erősödik a partnerek közötti kölcsönös hủség (Evans - Laskin, 1994). Mivel jelen tanulmányban az elégedettség rövid távon tetten érhető következményeire koncentrálunk, ezért az elméleti összefoglaló és a kutatás során a viselkedési szándékok közül csak az újravásárlási szándékot, valamint a pozitív szájreklámot elemezzük, és a személyes jellemzők moderáló hatását ezen relációk mentén szeretnénk megvizsgálni.

\subsubsection{A jövőbeli magatartási modellek}

A magas szolgáltatásminőség kedvező viselkedési szándékhoz vezet (Zeithaml et al., 1996), mely szándék pozitívan befolyásolja, hogy az egyén marad-e a vállalatnál vagy újat keres. Minél kellemesebb a fogyasztói élmény, annál nagyon valószínűséggel akarja az egyén újra használni a szolgáltatást (Zhang - Prybutok, 2005). Sokan ezt a dimenziót a siker egy mutatójaként értelmezik (Bhattacherjee, 2001; Venkatesh et al., 2003). A továbbiakban azokat az elméleteket mutatjuk be, amelyek a jövőbeli viselkedés elörejelzésére koncentrálnak.

Az egyik legjelentősebb modell a témában a logikus cselekvések elmélete (TRA/Theory of reasoned action) (Fishbein - Ajzen, 1975), mely szerint az egyén megatartását a viselkedési szándék határozza meg közvetlenül. Ezt két tényező befolyásolja: az attitüdök, illetve a szubjektív normák. Az attitüd egy összetett fogalom, amelyet meghatároznak az értékelő hiedelmek - vagyis hogy az egyén hogyan vélekedik az adott magatartás következményeiről -, valamint az attitüdök érzékelt fontossága. A normatív hiedelmek kategória azt jelenti, hogy az egyén hogyan látja a társadalmi elvárásokat, és mennyire szeretne azoknak megfelelni. Ezek a hiedelmek és a vélt fontosságuk határozzák meg a szubjektív normákat.

Egy másik jelentős koncepció a tervezett viselkedés modellje (TPB/ Theory of planned behavior) (Ajzen, 1985), mely egy plusz elemmel, az észlelt viselkedési kontroll tényezőjével egészíti ki az előző megközelítést.

A technológiaelfogadás tanulmányozására szolgáló modellek közül legszélesebb körben alkalmazott elméleti keret a technológia elfogadási modellje (TAM/Technology acceptance model) (Davis, 1989), mely szerint valamely technológiai rendszer elfogadásának a valószínüségét az észlelt hasznosság (Perceived Usefulness, $P U$ ), illetve a használat észlelt egyszerüsége (Perceived Ease Of Use, PEOE) befolyásolja (Nyírő, 
2011). Ezen tényezők hatnak a használat iránti attitűdre, mely befolyásolja a használati szándékot.

Az UTAUT (Unified Theory of Acceptance and Use of Technology) modell (Venkatesh et al., 2003) a technológiaelfogadási elméletet bővíti tovább. A koncepció szerint a használati szándékot négy dimenzió határozza meg: (1) a teljesítménnyel kapcsolatos várakozás (hasonló az észlelt hasznosság kategóriához), (2) az erőfeszítésekkel kapcsolatos várakozás (hasonló a használat egyszerüsége kategóriához), (3) a társadalmi befolyás/szociális befolyás (hasonló az szubjektív normák kategóriához), illetve (4) a támogató feltételek (hasonló az észlelt viselkedési kontroll kategóriához).

Az információs rendszerek folytonos modellje (IS Continuance Model) szerint egy rendszer sikerét a folyamatos használat adja (Bhattacherjee, 2001). A megközelítés öt lépcsőt foglal magában:

1. kezdeti elvárások a használattal kapcsolatban,

2. a rendszer elfogadása és használat,

3. a használat utáni észlelt fejlődés,

4. a kezdeti elvárások értékelése és az elégedettség vagy elégedetlenség kialakulása,

5. egy folyamatos szándék kialakítása, amennyiben az egyén elégedett a rendszerrel.

Jelen elgondolás hasonlít a korábban bemutatott minőség-elégedettség megközelítésekhez. Emellett észre lehet venni azt is, hogy ezeknek a magatartási modelleknek a dimenziói részben az elektronikus szolgáltatásminőség koncepciók esetében is tetten érthetőek, így például a használat egyszerüsége vagy a teljesítmény.

A ténnyel, hogy a szolgáltatásminőség hatással van az elégedettségre, számos szerző egyetért. Egyesek az elgondolást azzal egészítik ki, hogy ezek a tényezők a viselkedési szándékot is befolyásolják (Cronin - Taylor, 1992; Brady - Robertson, 2001). Cronin és társainak (2000) kutatása is bizonyítja, hogy a minőségnek közvetlen hatása van a viselkedési szándékra. Ezt a gondolatmenetet követve alkotta meg Godwin, Bagchi és Kirs (2010) saját modelljét, amely a jövőbeli viselkedési szándékot (a tanulmány esetében az újravásárlási szándékot) az elégedettség dimenziójával összefonódva vizsgálja, és e kapcsolat meglétét empirikus kutatással bizonyítják. Jelen kutatásban a jövőbeli 
viselkedési szándék alatt csak az újravásárlási szándékot és a pozitív szájreklámot értjük, és vizsgáljuk.

\subsubsection{Az újravásárlási szándék és a szájreklám kapcsolata az elégedettséggel}

A viselkedési szándék lehet kedvező, illetve kedvezőtlen is (Zeithaml et al.,1996), és ennek alakulását online környezetben is számos tényező (elégedettség, hírnév, megbízhatóság stb.) befolyásolja (Goode - Harris, 2009).

A korábbi kutatások az újravásárlás valószínüségének szintjével mérték a lojalitást (Lipstein, 1959; Kuehn, 1962; Srinivasan et al., 2002), mely koncepciót jelentős kritikák érték. Ez a viselkedésalapú megközelítés nem tesz különbséget a ténylegesen lojális és az állojális vásárlók között. Az újravásárlás okaként számos szituációs hatás is megjelenhet, úgymint az alternatívák hiánya, a változatosságkeresés iránti vágy hiánya, a preferált márka hiánya stb. (Day, 1969; Jacoby - Chestnut, 1978; Srinivasan, et al., 2002). Engel és Blackwell (1982) szerint a lojalitás egy preferenciajellegü, attitüdalapú viselkedési válasz egy vagy több márka iránt egy termékkategóriában egy adott vásárlás során. Assael (1992) szerint a lojalitás kedvező attitűd egy márka iránt, mely folyamatos vásárlásban nyilvánul meg. Gremler szerint a lojalitást (1995, in Srinivasan et al., 2002) mint attitüdöt és viselkedési aspektust is kell mérni. Mivel az elégedettség és az attitüd különbözőségét már a korábbi részben is bemutattuk, ezért a fenti definíciókat figyelembe véve megállapítható, hogy a lojalitásnak mind viselkedésbeli, mind pedig attitüdjellegü megnyilvánulása is létezik. A fogyasztó csak akkor mondható igazán lojálisnak, amikor az újravásárlás mértéke és a relatív attitűd értéke is magas. Az attitüd erőssége/szélsősége, illetve az attitüdök közötti differenciálás alapján alakulhat ki a relatív attitüd. Ha a megkülönböztetés képessége magas, akkor magas a relatív attitüd értéke (Dick - Basu, 1994; Kenesei - Kolos, 2007; Dörnyei - Gyulavári, 2012).

\begin{tabular}{|c|c|c|c|}
\hline & & \multicolumn{2}{|c|}{ Az újravásárlás ismétlődése } \\
\hline & & Gyakori & Ritka \\
\hline Relatív & pozitív & Lojalitás & Látens lojalitás \\
\hline attitüd & negatív & Látszólagos lojalitás & Lojalitás hiánya \\
\hline
\end{tabular}

16. ábra: A szolgáltatásokkal szembeni lojalitás típusai

Forrás: Dick és Basu (1994), in: Dörnyei-Gyulavári (2012)

Összefoglalásként megállapítható, hogy a lojalitást sok esetben egy márka/termék többszöri újravásárlásaként, vagy boltok esetében egy üzlet többszöri újraválasztásaként definiálják: az irodalom alapján minimum 3-4 sikeres ismétlés után beszélhetünk 
hűségről. (Ltifi - Gharbi, 2012a). Dick és Basu (1994) megközelítését követve valódi lojalitás csak akkor alakul ki, amikor az újravásárlás mellett a relatív attitűd is magas. Jelen tanulmányban az újravásárlási szándékot mint viselkedési szándékot elemezzük, és a lojalitással való kapcsolatát a hosszú távú megnyilvánulás miatt mellőzzük (16. ábra).

A szájreklám formális vagy informális kommunikációt jelent mások felé a szolgáltatásról, termékről (Hennig-Thurau et al., 2002). Ez vállalaton kívüli, természetes környezetből fakadó kommunikáció, és magas hihetőség által jellemzett szemben a reklámokkal, valamint ingyenes megjelenést, publicitást jelent a vállalatnak (Srinivasan et al., 2002).

A szájreklám a vásárlási döntési szituációban egy jelentős, külső információforrást jelent, amit olyan egyén vagy vállalkozás indíthat, akinek tapasztalata van az adott termékkel, szolgáltatással kapcsolatban, és ennek köszönhetően megfelelő információt juttat el a befogadó számára (Eszes, 2011). A szájreklám a szolgáltatások esetében különösen jelentős hatással bír (Kenesei - Kolos, 2007).

„A szájreklám (word of mouth) informális pozitív vagy negativ tartalmú kommunikációt jelent az ügyfelek között, egy vállalatról, annak termékéröl vagy szolgáltatásáról” (Tax et al., 1993, 74. o., in: Neumann-Bódi, 2012).

Napjainkban a fogyasztók számára elérhető, internetezésre alkalmas eszközök és megoldások lehetővé tették az online szájreklám kialakulását, amely elsősorban abban különbözik a hagyományos formától, hogy mivel elektronikus felületen zajlik, általában nincs közvetlen face-to-face kommunikáció, a vélemények, ajánlások alapvetően kéretlenek, és csak akkor kerülnek értékelésre, ha a leendő befogadók éppen rátalálnak, felfigyelnek rá (Park - Kim, 2008). Az e-WOM esetében a vélemények a korábban megszokottnál nagyobb mértékben és sebességgel terjedhetnek. A hagyományos szájreklám esetében az információ privát beszélgetések során kerül átadásra, míg online esetben olyan egyénekhez, csoportokhoz is eljuthat, akik nincsenek jelen az adott pillanatban (Karakaya - Barnes, 2010), vagy nem ismerik, illetve ismerhetik egymást. Míg offline esetben egyidejü véleménymegosztás történik egyének vagy kisebb csoportok között (Steffes - Burgee, 2009), addig online esetben aszinkron (Hung - Li, 2007), többutas formában kerül rá sor, amelynek révén tartósabbnak és elérhetőbbnek is tekinthető. Ezáltal az e-WOM mérhetőbbé, elemezhetőbbé is válik (Park - Kim, 2008), hiszen általában előre meg nem határozott ideig tárolásra kerül (Henning-Thurau et al., 2004). Az online szájreklám szakirodalmak által leginkább felhasznált, Hennig-Thurau 
és szerzőtársai (2004) által kidolgozott fogalma alapján online szájreklám alatt értünk minden olyan pozitív vagy negatív állítást, amelyet jelenlegi, potenciális vagy korábbi fogyasztók tesznek közzé egy termékről/szolgáltatásról vagy vállalatról, és amely hozzászólások több fogyasztó számára elérhetők az internet felületén keresztül.

Az elégedettség vásárlás utáni magatartásban megjelenő hatását (pl. szájreklám és újravásárlás) tanulmányok támasztják alá (Kim, 2005). A fogyasztó elégedettsége a korábbi vásárlási tapasztalatait figyelembe véve alakul ki egy adott elektronikus kereskedelmi céggel, amely befolyásolja az újravásárlási szándékot (Hsu et al., 2012). Wolfinbarger és Gilly (2003) eredményei alapján megállapítható, hogy az általuk megalkotott eTAILQ elektronikus szolgáltatásminőség skála esetében a fogyasztói elégedettségben a megbízhatóság dimenziója bizonyult a legfontosabbnak, és ha a minőségdimenziók közvetlen hatását vizsgáljuk az újravásárlási szándékra, akkor ez a második legfontosabbnak tényező. Loiacono, Watson és Goodhue (2007) eredményei is alátámasztják az elégedettség hatását az újralátogatásra, illetve az újravásárlásra. A tényt, hogy az elégedettség befolyásolja a vásárlási szándékot és a szájreklámot Dolen, Dabholkar és Buyter (2007, in: Moon, Philip, Moon, 2011) eredményei is igazolják. Ha, Muthaly és Akamavi (2010) kutatása alapján is elfogadható az a feltevés, hogy az elégedettség közvetlenül befolyásolja az online újravásárlási szándékot. Kim (2012) szerint az elégedettség vizsgálata online környezetben az újravásárlással kapcsolatban azért is fontos, mert sokszor a fizetés a szállítás előtt történik, ezért bizalmat kell az eladónak biztosítani. Amennyiben a fogyasztó elégedetett, kölcsönös megértés alakul ki, és sokkal valószínübb, hogy a kapcsolatuk folytatódik. Amennyiben az elégedettség a teljesítménnyel kapcsolatban nő, akkor a tranzakciók megismétlésének szándéka - az újravásárlási szándék - is nő (Kim, 2012).

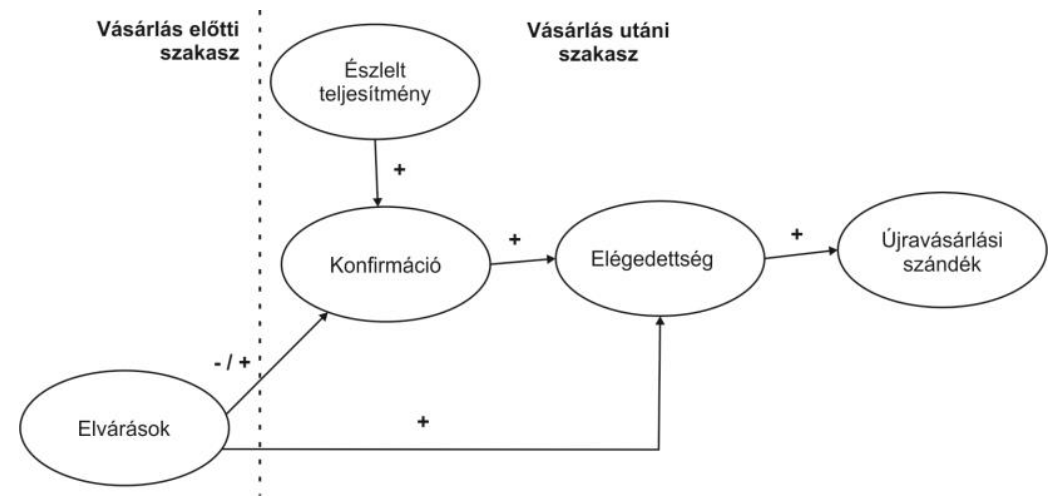

17. ábra: Elvárások-konfirmáció elmélet

Forrás: Anderson - Srinivasan (2003) 
Ahogy azt a 17. ábra is mutatja, a fogyasztói elégedettség szintje befolyásolja, hogy az egyén hajlandó-e újravásárolni (Oliver, 1980; Anderson - Sullivan, 1993; Parasuraman Grewal, 2000). Fontos kiemelni, hogy hiába elégedett a vevő, amennyiben úgy érzi, hogy nem a legjobb ajánlatot kapta, hajlandó a versenytárshoz átpártolni (Anderson Srinivasan, 2003; Chang, 2006; Kanji, 2002), ami online környezetben sokkal kevesebb váltási költséget és erőfeszítést jelent, mivel a versenytársak csak „egy kattintásra” vannak.

\subsection{3. Összefoglalás}

A szakirodalom alapján elfogadható az a feltételezés, hogy az észlelt minőség jelentős hatással bír a fogyasztói elégedettségre. Ezt a kapcsolatrendszert azért éri meg részleteiben megismerni, mert az elégedettség számos olyan következménnyel bír, amelyek a sikeres vállalati müködést befolyásolják. Ezek közül az újravásárlási szándék, valamint a szájreklám részletes bemutatására került sor a szakirodalmi összefoglaló során. Az újravásárlási szándék azért bír kiemelt szereppel, mert az ismételt vásárlások hosszú távon a lojalitás kialakulását támogathatják, míg a pozitív szájreklám elősegíti az új vásárlók megszerzését, vagyis a vállalati marketingkommunikációt erősíti.

A minőségészlelés mérésére több lehetőség adódik, és jelen tanulmányban a diszkonfirmációs paradigmával foglalkoztunk részletesen, mely az elvárt és tapasztalt minőség alapján méri a teljes fogyasztói minőségészlelést, és ezen keresztül az elégedettséget. 


\section{AZ EMPIRIKUS KUTATÁS}

Disszertációm célja, hogy a Francis és White (2004) által meghatározott négy ekereskedelmi kategóriában, vagyis az offline-termékek, offline-szolgáltatások, elektronikus-termékek, valamint elektronikus-szolgáltatások piacán, elkülönítve, illetve egymáshoz viszonyítva megvizsgáljuk a konkrét vásárláshoz köthető újravásárlási valamint továbbajánlási szándék alakulását az elégedettség függvényében. Kutatásunk során részletesen górcső alá vesszük, hogy a négy szegmens esetében a szakirodalom alapján megismert elektronikus szolgáltatásminőség dimenziói milyen hatással bírnak az elégedettségre, és azon keresztül hogyan befolyásolják az újravásárlási, illetve a tradicionális és az elektronikus továbbajánlási szándékot. Fő motivációnk tehát, hogy feltárjuk a négy elektronikus kereskedelmi kategória közötti hasonlóságokat és a legjelentősebb eltéréseket, kvázi a vásárolt termék jellegét az egész modellben mint moderáló változót értelmezzük.

Motivációnk a szakirodalom feldolgozásából származik, ugyanis eddig nem találkoztunk olyan tanulmányokkal, amelyek az e-kereskedelem esetében a minőség-elégedettségelégedettségkövetkezmények kapcsolatrendszer ilyen jellegü, marketing szempontból is releváns, szeparált elemzésével foglalkoznak. Ebből kiindulva munkánk fő célkitüzése ennek a vizsgálatnak az elvégzése, valamint a hatások és kapcsolatok egymáshoz viszonyítása, mellyel tovább bővíthetjük az e-kereskedelemről szerzett akadémiai ismeretanyagot. Kutatásunknak köszönhetően egy komplex betekintést nyerhetünk az elektronikus kereskedelem esetében a fentebb megnevezett kapcsolatrendszer alakulásáról.

\subsection{A kutatás elméleti kerete}

Az irodalmi összefoglalóban bemutattuk az elektronikus szolgáltatásminőséghez, elégedettséghez és azok következményeihez tartozó koncepciókat. Kutatásunk során az elégedettség mérésére az ún. diszkonfirmációs paradigmát tervezetük használni, mely szerint az elégedettség alakulása attól függ, hogy a fogyasztó, jelen esetben az online vásárló elvárásai a vásárlással kapcsolatban és az e-kereskedelmi egység által nyújtott szolgáltatás tapasztalt teljesítménye milyen viszonyban állnak. Előzetes pilot kutatásaink eredményei azonban azt mutatják, hogy a válaszadók számára nehézséget okoz a minőség elvárt szintjének megfogalmazása, ezért mégis a direkt mérés mellett döntöttünk. 
Az e-szolgáltatásminőség mérésére a Francis (2009) által létrehozott és validált RECIPE skálát használtuk, mely a négy e-kereskedelmi szegmens egyediségeit is figyelembe véve határozta meg a releváns minőségdimenziókat. A skála az észlelt elektronikus szolgáltatásminőséget mint az elégedettség előzményét az elektronikus kereskedelem négy kategóriájában hasonló dimenziókkal, azonban eltérő manifeszt változókkal méri. Ezt a koncepciót külföldön empirikusan már tesztelték és validálták. Ahogy a 2.3.12. fejezetben már részletesen bemutattuk, a RECIPE skála esetében mind a négy szegmensben azonos módon került mérésre a vásárláshoz köthető biztonságérzet, valamint az ügyfélszolgálattal való kommunikáció. Habár a további dimenziók elnevezése különbözik, mégis a manifeszt változók részletes tanulmányozása alapján megállapítatható, hogy mind a négy esetben az egyik dimenzió a konkrét webshop, vagyis a honlapon fellelhető információk és a vásárláshoz szükséges instrukciók minőségéről szól. Ennek megfelelően ezeket a változókat - vagyis a holnapminőség, a termékrészletek, valamint a felhasználói fiók létrehozása dimenziókat - az elemzésünk során az egyszerüség kedvéért összefoglalóan a konkrét webshopminőség néven említjük. Ugyancsak hasonlóságok fedezhetőek fel a csere, a foglalás és a rendszerkezelés dimenzióinak alapos tanulmányozása során: ezek mind a tényleges vásárlás lebonyolításának minőségét foglalják magukban, vagyis a megrendelési folyamat, a visszajelezések és a fizetés minőségét. A továbbiakban ezeket a dimenziókat összefoglalóan a vásárlás lebonyolításának minősége névvel illetjük. A RECIPE skála részletes bemutatását, vagyis az indikátorait a 3. melléklet tartalmazza. Kutatásunk során azért ezt a koncepciót használjuk, mert a létező skálák közül ez az egyedüli, mely a mérés során figyelembe veszi az e-kereskedelem heterogén mivoltát, melynek vizsgálata több esetben jövőbeli kutatási irányként került megjelölésre (Wolfinbarger - Gilly, 2003; Francis - White, 2003, 2004; Parasuraman et al., 2005). Mindemellett a használt dimenziók az összefoglalásunk alapján az e-szolgáltatásminőség definícióját hiánytalanul lefedik, tehát a skála megfelelő tartalmai validitással rendelkezik.

\subsection{Kutatási kérdések és hipotézisek}

Elméleti keretmodellünket a szakirodalom feldolgozása, valamint az elmúlt években végzett kutatásaink tapasztalata alapján építettük fel (18. ábra). A modell alapján a disszertáció fő kérdése, hogy a különböző e-kereskedelmi kategóriák esetében megfigyelhetőek-e szignifikáns különbségek az elégedettség és következményeinek alakulása során. A felvázolt elméleti keretben a négy szegmens esetében mindössze az 
elektronikus szolgáltatásminőség alkotóelemei különbözhetnek (lásd korábbi fejezetek), a többi kapcsolatrendszert a szakirodalom alapján ugyanolyannak feltételezzük.

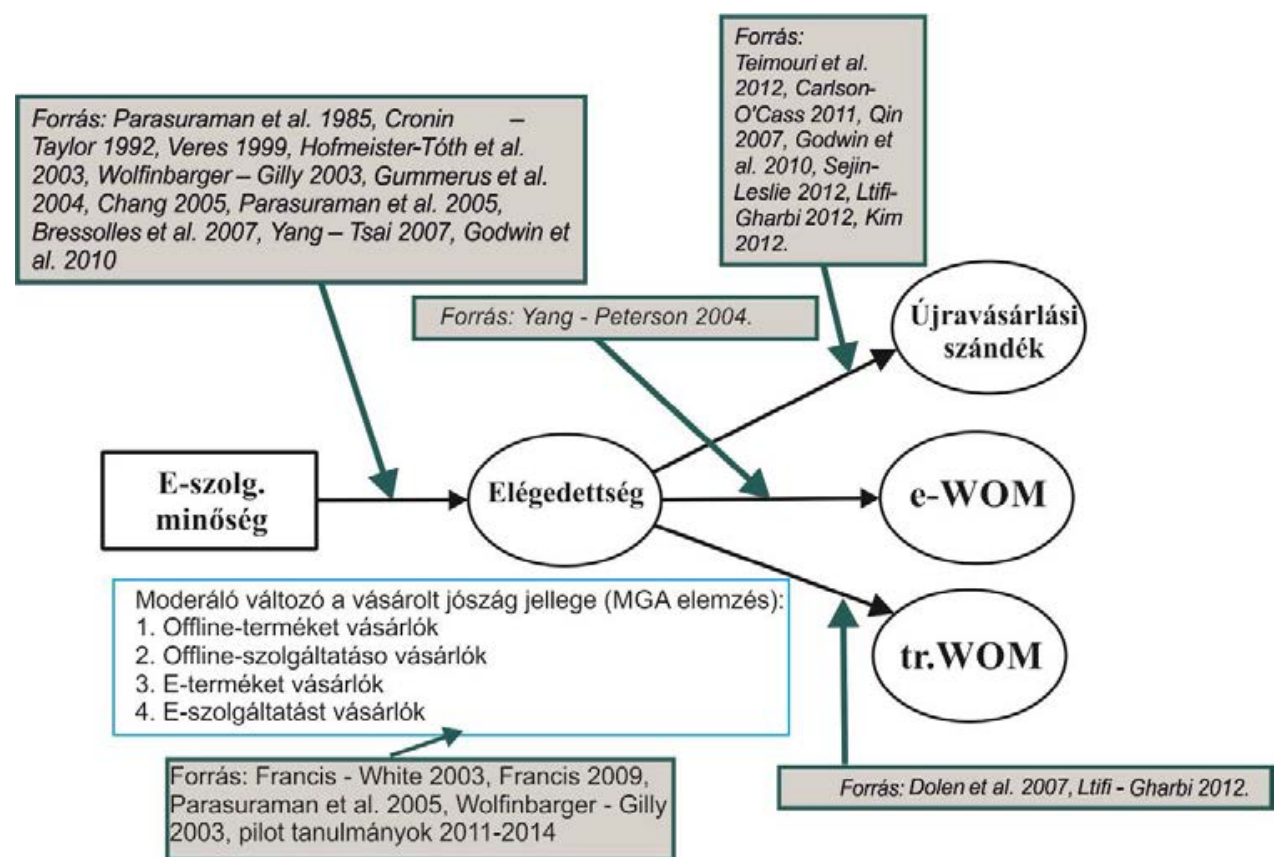

\section{8. ábra: A kiindulási elméleti keret}

Forrás: saját szerkesztés

A megalkotott modell alapján a következő kutatási kérdéseket és kiinduló hipotéziseket fogalmaztuk meg.

A minőség pozitív kapcsolatát az elégedettséggel számtalan tanulmány bizonyítja az offline világban, és az elektronikus szolgáltatásminőség esetében is több kutatás támasztja alá ezt a tényt (Wolfinbarger - Gilly, 2002, 2003; Bauer et al., 2005; Bressoles - Nantel, 2004; Qin, 2007; Chang et al., 2009; Godwin et al., 2009; Carlson - O'Cass, 2011; Kim, 2012; Sejin - Leslie, 2012). Kevés kivételtől eltekintve (Qin, 2007; Kim, 2012) a kutatások többsége a minőség direkt mérését alkalmazza, és nem veszi figyelembe a diszkonfirmációs paradigmát.

A kutatások többsége az elektronikus szolgáltatásminőség dimenzióját homogén fogalomként kezeli, amit több korábbi tanulmány is kritikával illetett. A hagyományos, offline területek esetében is úgy gondolják, hogy a termékek és szolgáltatások vásárlása esetében eltérő manifeszt változókkal érdemes az minőségészlelést mérni (Babakus Boller, 1992; Carman, 1990; Gagliano - Hathcote, 1994), mégis az e-kereskedelemi kutatások nagy részre ezt nem veszi figyelembe. Egyes tanulmányok a jószág jellegéből adódó különbségektől teljes mértékben eltekintetnek (Janda et al., 2002; Long és 
McMellon, 2004; Ribbink et al., 2004), míg mások jövőbeli kutatási irányként jelölik meg a jószágcsoportonként lehetséges módosításokat (Parasuraman et al., 2005; Wolfinbarger - Gilly, 2003). A minőségészlelés mérése során kutatásunkban erre a kritikus pontra helyezzük a hangsúlyt.

H1: Az elektronikus szolgáltatásminőség dimenziói pozitív hatással bírnak az elégedettség alakulására.

H1.1: A konkrét webshopminőség dimenziója szignifikáns, pozitív hatással bír az elégedettségre.

H1.2: A vásárlás lebonyolításának minősége szignifikáns, pozitív hatással bír az elégedettségre

H1.3: Az észlelt biztonság dimenziója szignifikáns, pozitív hatással bír az elégedettségre H1.4: Az ügyfélszolgálat minőségének dimenziója szignifikáns, pozitív hatással bír az elégedettségre

Függö változó: elégedettség

Mérésre alkalmazott skála: Chang et al., 2009

Független változók: elektronikus szolgáltatásminöség

Mérésre alkalmazott skála: RECIPE skála (Francis, 2009)

Hosszú évek óta jól ismert tény, hogy az elégedettség pozitív következményei között szerepel az újravásárlási szándék, mely tényt online környezetben is több ízben alátámasztották már (Teimouri et al., 2012; Carlson - O’Cass, 2011; Qin, 2007; Godwin et al., 2010). Az elégedettség mediáló hatását a minőség és újravásárlási szándék között is számos kutatás bizonyítja mind az online (Sejin - Leslie, 2012; Ltifi - Gharbi, 2012; Kim, 2012), mind pedig az offline vásárlás során (Cronin et al., 2000). Habár vannak, akik a minőségdimenziók közvetlen hatását tarják relevánsnak az újravásárlási szándékra (Loiacono et al., 2000, 2007; Yoo - Donthu, 2001; Bauer et al., 2005; Carlson - O'Cass, 2011), mégis kutatásunk során az elégedettség mediáló voltát elemezzük a különböző ekereskedelemi kategóriákban, és Francis (2009) felvetései alapján szeretnénk az elégedettség és az újravásárlási szándék közötti hatások különbözőségét részleteiben megvizsgálni.

H2: Az elégedettség minden egyes elektronikus kereskedelmi kategóriában pozitív hatással bír az újravásárlási szándékra. 
Függő változó: újravásárlási szándék

Mérésre alkalmazott skála: Limayem, Khalifa és Frini, 2000

Független változók: elégedettség

H3: Az elégedettség újravásárlási szándékra gyakorolt hatása a különböző ekereskedelmi kategóriákban szignifikánsan eltér.

H3.1: Az elégedettség erősebb pozitív hatással bír az újravásárlási szándékra az offline-termékek esetében, mint az e-termékek esetében.

H3.2: Az elégedettség erősebb pozitív hatással bír az újravásárlási szándékra az offline-termékek esetében, mint az offline-szolgáltatások esetében.

H3.3: Az elégedettség erősebb pozitív hatással bír az újravásárlási szándékra az offline-termékek esetében, mint az e-szolgáltatások esetében.

H3.4: Az elégedettség erősebb pozitív hatással bír az újravásárlási szándékra az etermékek esetében, mint az offline-szolgáltatások esetében.

H3.5: Az elégedettség erősebb pozitív hatással bír az újravásárlási szándékra az etermékek esetében, mint az e-szolgáltatások esetében.

H3.6: Az elégedettség erősebb pozitív hatással bír az újravásárlási szándékra az offline-szolgáltatások esetében, mint az e-szolgáltatások esetében.

Az elégedettség egy másik jelentős következménye a továbbajánlás, mely a pozitív szájreklámok közé tartozik (Neuman-Bódi, 2013). A kapcsolat kutatására az online vásárláshoz köthetően 2010-ig kevés tanulmány született (Chang et al., 2009), mivel a többség az újrahasználatra, az újravásárlásra, illetve a lojalitásra koncentrál. Smith és társainak (2005) kutatása alapján döntöttünk úgy, hogy munkánk során a továbbajánlási szándék alakulását is megvizsgáljuk a vásárláshoz köthető elégedettség függvényében, mivel eredményeik alapján megállapítható, hogy online környezetben a vásárlás inkább az ajánlás következménye, mintsem az eladóval folytatott interakcióé, valamint ez a magatartásforma - a továbbajánlás - a vállalati kommunikáció támogatása szempontjából is releváns. Dolen, Dabholkar és Ruyter (2007) eredményei alapján online közegben az elégedettség a továbbajánlási hajlandóságot befolyásolja, amit Ltifi és Gharbi (2012) azzal egészít ki, hogy mind a kognitív, mind pedig az érzelmi elégedettség hatással bír a pozitív szájreklámra.

Kutatásunk során tehát megkülönböztetjük a hagyományos (H4 - H5) és az online továbbajánlási szándékot (H6 - H7), és az elégedettség hatását a két továbbajánlási módra 
mind a négy e-kereskedelmi csoportban szeparáltan, valamint az új információk, eredmények gyüjtése céljából egymáshoz viszonyítva is megvizsgáljuk.

H4: Az elégedettség minden egyes e-kereskedelmi kategóriában pozitív hatással bír a hagyományos továbbajánlási szándékra.

Függő változó: továbbajánlási szándék

Mérésre alkalmazott skála: Zeithaml et al., 1996

Független változók: elégedettség

H5: Az elégedettség hagyományos továbbajánlási szándékra gyakorolt hatása a különböző e-kereskedelmi kategóriákban szignifikánsan eltér.

H5.1: Az elégedettség erősebb pozitív hatással bír a hagyományos továbbajánlási szándékra az offline-termékek esetében, mint az e-termékek esetében.

H5.2: Az elégedettség erősebb pozitív hatással bír a hagyományos továbbajánlási szándékra az offline-termékek esetében, mint az offline-szolgáltatások esetében.

H5.3: Az elégedettség erősebb pozitív hatással bír a hagyományos továbbajánlási szándékra az offline-termékek esetében, mint az e-szolgáltatások esetében.

H5.4: Az elégedettség erősebb pozitív hatással bír a hagyományos továbbajánlási szándékra az e-termékek esetében, mint az offline-szolgáltatások esetében.

H5.5: Az elégedettség erősebb pozitív hatással bír a hagyományos továbbajánlási szándékra az e-termékek esetében, mint az e-szolgáltatások esetében.

H5.6: Az elégedettség erősebb pozitív hatással bír a hagyományos továbbajánlási szándékra az offline-szolgáltatások esetében, mint az e-szolgáltatások esetében.

H6: Az elégedettség minden egyes e-kereskedelmi kategóriában pozitív hatással bír az elektronikus továbbajánlási szándékra.

Függö változó: továbbajánlási szándék

Mérésre alkalmazott skála: Yang és Peterson, 2004

Független változók: elégedettség

H7: Az elégedettség elektronikus továbbajánlási szándékra gyakorolt hatása a különböző e-kereskedelmi kategóriákban szignifikánsan eltér.

H7.1: Az elégedettség erősebb pozitív hatással bír az elektronikus továbbajánlási szándékra az offline-termékek esetében, mint az e-termékek esetében.

H7.2: Az elégedettség erősebb pozitív hatással bír az elektronikus továbbajánlási szándékra az offline-termékek esetében, mint az offline-szolgáltatások esetében. 
H7.3: Az elégedettség erősebb pozitív hatással bír az elektronikus továbbajánlási szándékra az offline-termékek esetében, mint az e-szolgáltatások esetében.

H7.4: Az elégedettség erősebb pozitív hatással bír az elektronikus továbbajánlási szándékra az e-termékek esetében, mint az offline-szolgáltatások esetében.

H7.5: Az elégedettség erősebb pozitív hatással bír az elektronikus továbbajánlási szándékra az e-termékek esetében, mint az e-szolgáltatások esetében.

H7.6: Az elégedettség erősebb pozitív hatással bír az elektronikus továbbajánlási szándékra az offline-szolgáltatások esetében, mint az e-szolgáltatások esetében.

\subsection{Az elméleti fogalmak operacionalizálása}

Kutatásunk megkezdése előtt az elektronikus szolgáltatásminőség, elégedettség, újravásárlási szándék, továbbajánlás fogalmak operacionalizálása is szükséges.

Ahogy azt korábban láthattuk, az elektronikus szolgáltatásminőség mérésére számos validált skála született, azonban ezek egy része nem tért ki az online vásárlás teljes folyamatára, valamint a többségük nem veszi figyelembe az elektronikus kereskedelem heterogén jellegét. Ezen limitációk miatt kutatásunk során Francis (2009) RECIPE skáláját tervezzük alkalmazni, mely a fentebb megnevezett értékelési kritériumok mindegyikének megfelel, vagyis az elektronikus szolgáltatásminőség minden dimenzióját lefedik a skálához tartozó manifeszt változók, valamint a skálát úgy alkották meg, hogy a különböző e-kereskedelmi vásárlási szituációhoz alkalmazkodó, validált mérési változókkal dolgozik.

Offline-termékek esetében a minőséget mérő skála négy dimenziót alkalmaz 19 mérési tétellel:
1. Honlapminőség,
2. Csere: fizetés és kézhezvétel,
3. Ügyfélszolgálat,
4. Biztonság.

Az offline-szolgáltatások esetében a csere dimenzió helyét átveszi egy új faktor. Ez a skála 18 indikátort foglal magában:

1. Honlapminőség,

2. Foglalás/vásárlás,

3. Ügyfélszolgálat, 


\section{Biztonság.}

Az elektronikus-termékek esetében a termékrészletek jelenik meg új dimenzióként, és 19 mérési tétellel dolgozik a skála:

1. Termékrészletek,

2. Csere folyamata,

3. Ügyfélszolgálat,

4. Biztonság.

A dimenziók tekintetében a legnagyobb eltérés az elektronikus-szolgáltatásokhoz tartozó minőség mérésére szolgáló skála esetében figyelhető meg. A dimenziók száma itt is négy, 20 mérési tétellel:

1. Felhasználói fiók létrehozása,

2. Rendszer/fiók kezelése,

3. Ügyfélszolgálat,

4. Biztonság.

Ahogy korábban említettük, a hasonló dimenziókat az egyszerüség kedvéért összefoglaló névvel láttuk el, vagyis a következő négy látensre hivatkozunk a jövőben:

1. Konkrét webshopminőség, mely a különböző szegmensekben az alábbi dimenzióknak felel meg: holnapminőség (offline-termék és szolgáltatások), termékrészletek (e-termékek), felhasználói fiók létrehozása (e-szolgáltatás).

2. Vásárlás lebonyolitásának minősége, mely a négy szegmens esetében az alábbi dimenzióknak felel meg: csere (offline és e-termékek), foglalás (offlineszolgáltatások), rendszer-/fiókkezelés (e-szolgáltatás).

\section{3. Ügyfélszolgálat}

4. Biztonság

A fogyasztói elégedettség a korábbi vásárlási tapasztalatokat is figyelembe véve alakul ki egy adott céggel vagy vásárlási folyamattal kapcsolatban (Anderson - Srinivasan, 2003). Kutatásunk során Oliver (1980) offline környezetre kialakított, majd Anderson és Srinivasan (2003) online környezetre módosított elégedettségskálájának egyszerüsített változatát használjuk (Chang et al., 2009), mely három mérési tétellel Likert-skálán méri 1-7-ig az elégedettséget, és egy fordított tételt is tartalmaz. Ezen fordított értékelések a hazai lakosság körében nem működnek megfelelően (Kenesei, 2000), mely tényt saját próbakérdezésünk is alátámasztott, ezért ezeket a mérési tételeket átfogalmaztuk, hogy az 
azonos irányú értékelés megoldható legyen. A skálát korábbi kutatásink során már többször is használtuk.

1. I am satisfied with my decision to purchase from this Web site. Elégedett vagyok a döntésemmel, hogy ezen az oldalon vásároltam.

2. If I had to purchase again, I would feel differently about buying from this Web site. ${ }^{\mathrm{R}}$

Ha újra vásárolnék ezen a helyen, valószinüleg ugyanúgy értékelném a honlapot/céget.

3. My choice to purchase from this Web site was a wise one. Jó döntés volt ezen az oldalon vásárolni.

Az újravásárlási szándékot Limayem, Khalifa és Frini (2000) módosított vásárlási szándék skálájával terveztük mérni ${ }^{5}$, azonban a próbakérdezések alapján megállapíthatjuk, hogy a válaszadók nem tudtak különbséget tenni az állítások között, és zavarólag hatott a hasonló tartalom négyszeri lekérdezése, ezért végül az újravásárlási szándék direkt mérése mellett döntöttünk a második tétel felhasználásával.

1. I intend to purchase through this site in the near future. Szándékozom a közeljövőben vásárolni erröl az oldalról.

Az offline, hagyományos továbbajánlási szándékot Zeithaml és társainak 1996-os skálája alapján mértük. A skála magyar fordítást Neumann-Bóditól (2012) vettük át.

1. I say positive things about this company to persons in my environment. Pozitív dolgokat mondanék másoknak erröl a webáruházról.

2. If somebody seeks for advice I recommend this company. Ajánlanám a webáruházat azoknak, akik kíváncsiak a tanácsomra.

3. I encourage relatives and friends to do business with this company.

Bátorítanám a barátaimat és rokonaimat, hogy használják ezt a webáruházat.

A konkrét vásárlási szituációhoz köthető elektronikus továbbajánlási szándék mérésére a szakirodalomban egy releváns skálát találtunk, amely az alábbi egy változóval, direkt méri az e-továbbajánlási szándékot (Yang és Peterson, 2004):

1. I would post positive messages about the company on some Internet message board.

\footnotetext{
${ }^{5}$ I will definitely buy products from this site in the near future.

Biztosan fogok vásárolni erröl az oldalról a közeljövőben.

I intend to purchase through this site in the near future.

Szándékozom a közeljövőben vásárolni erröl az oldalról.

It is likely that I will purchase through this site in the near future.

Feltehetöen a közeljövöben fogok vásárolni erröl az oldalról.

I expect to purchase through this site in the near future.

Valószínünek tartom, hogy a közeljövőben fogok vásárolni erröl az oldalról.
} 
Az oldalról szívesen osztanék meg pozitív véleményt az interneten.

\subsection{A kutatás módszertana}

Ph.D. kutatásom két részre bontható. Az első részben az elemzéshez szükséges adatok és szekunder információk rendszerezése, valamint a kutatási folyamat megtervezése és előkészítése történt, melyek alapján kialakításra került a kutatási keretkoncepció. A második szakasz erre épülve egy általánosítható eredményeket biztosító kvantitatív kutatási szakaszt és egy kísérleti kutatást tartalmaz. E kutatások célja a hipotéziseink tesztelése, és a minőségdimenziók relevanciájának megértése az elégedettség függvényében.

$\mathrm{Az}$ elektronikus szolgáltatásminőség, valamint az online elégedettség irodalma többségében idegen nyelven áll rendelkezésünkre, ezért szükséges az összegyüjtött információk értékelése, és a hazai piacon történő alkalmazhatóságuk mérlegelése. Ennek vizsgálatára már korábbi pilotkutatások születtek, amelyeket a 11. számú melléklet tartalmaz. Ezek az előtanulmányok a hipotézisek felállításában, és a kereskedelmi kategóriák közötti különbségek feltáró azonosítására szolgáltak.

A második kutatási fázisban került sor a kvantitatív kutatási szakaszra, melynek célja a kialakított modell tesztelése, a hipotézisek vizsgálata. Ennek elvégzésére online kérdőíves megkérdezést, illetve hallgatói kísérletet használtunk.

Az online megkérdezés során offline és online e-kereskedelmi kategóriánként 500-500, összesen 1000 fös, független mintát használtunk. Az így kapott adatbázist felhasználva a hipotéziseink, illetve a modell értékelésére a PLS-SEM módszertant használtuk.

A második kutatás, vagyis a kísérlet célja kettős. Első körben szeretnénk megvizsgálni, hogy ugyanazt a webshopot felhasználva milyen értékelések születnek két különböző terméktípus - egy offline-termék (ruházati kiegészítő) és egy e-termék (e-könyv) - első, illetve újravásárlása során (A és B szcenárió), és hogy a nagymintás kutatás során feltárt különbségek vajon ebben az esetben is léteznek-e. Másodlagos célunk, hogy a tartalomelemzés módszerét felhasználva a vásárláshoz köthető kommentek/posztok vizsgálatával minél melyebben megérthessük a minőségészlelést és az értékelések miértjét. A kísérletben egy 100 fős hallgatói mintával dolgoztunk, olyan egyénekkel, akik az elmúlt három hónap során vásároltak online. Minden megkérdezettnek ugyanazt a fiktív webshopot használva kellett két darab irányított vásárlási szituációt véghezvinnie, 
valamint a vásárláshoz kapcsolódóan egy online kommentet megfogalmaznia. A kutatás során minden vásárlás végén egy kérdőívet kitöltetve a résztvevők minőségészlelését, elégedettségét, újravásárlási szándékát, valamint a hagyományos és e-továbbajánlási hajlandóságát is mértük. Azért gondoltuk szükségesnek a kísérlet megvalósítását is, mert a nagymintás online megkérdezés számos limitációval rendelkezik (nem különbözteti meg az első vagy újravásárlási szituációkat, a megkérdezettek különböző honlapokat értékeltek), melyeket a kísérletben megpróbáltunk kiküszöbölni, valamint így bizonyos szintü kvalitatív belátást is nyerhettünk az eredményekbe. A kísérlet az elmúlt években vált a marketing közkedvelt kutatási módszerévé is (Baum - Spann, 2011). A tervezett kutatási módszereket a 7. táblázat foglalja össze.

\begin{tabular}{|l|l|l|}
\hline Kutatási módszer & \multicolumn{1}{|c|}{ ONLINE MEGKÉRDEZÉS } & \multicolumn{1}{|c|}{ KíSÉRLET } \\
\hline Kutatás ismertetése & $\begin{array}{l}\text { Online kutatás, minden egyes e- } \\
\text { kereskedelmi kategóriában egy-egy } \\
\text { partner ügyfelei körében, vagy a hazai } \\
18+\text { internetezők körében reprezentatív } \\
\text { minta }\end{array}$ & $\begin{array}{l}\text { Online vásárlás szituáció fiktív } \\
\text { web-shopok esetében mind a négy } \\
\text { kategóriában (offline-termék/ e- } \\
\text { termék.) való lekérdezése online } \\
\text { módon. }\end{array}$ \\
\hline Válaszadók & Az elmúlt egy évben online vásárolt & $\begin{array}{l}\text { Hallgatói minta, az elmúlt egy } \\
\text { évben interneten vásárolt }\end{array}$ \\
\hline Mintanagyság & $\begin{array}{l}\text { 500-500 fös kvóta (offline/online } \\
\text { teljesitésú jószágok vásárlása) }\end{array}$ & n=100 fő \\
\hline Adatfelvétel időpontja & 2014. I. negyedév & 2014. IV. negyedév \\
\hline Elemzés módszere & $\begin{array}{l}\text { SPSS - egy illetve többváltozós } \\
\text { statisztikák } \\
\text { SmartPLS - strukturális modellezés }\end{array}$ & $\begin{array}{l}\text { SPSS - egy illetve többváltozós } \\
\text { statisztikák } \\
\text { SmartPLS } \\
\text { modellezés }\end{array}$ \\
\hline Vizsgált hipotézis & $\begin{array}{l}\text { H1.1-4., H2, H3.1-6., H4, H5.1-6., H6, } \\
\text { H7.1-6. }\end{array}$ & H2, H3.1, H4, H5.1, H6, H7.1 \\
\hline
\end{tabular}

\section{7. táblázat: A tervezett kutatási módszertan}

Forrás: saját szerkesztés

\subsection{Elemzési módszertan: variancia és/vagy kovariancia alapú modellezés}

Az oksági összefüggések vizsgálata egyszerübb esetben regresszióelemzéssel, faktorelemzéssel történik, míg komplexebb modellek esetében megkülönböztetünk variancia és kovariancia alapú elemzéseket. Ezekben az esetekben a modell tartalmazhat látens, nem megfigyelhető változókat is. Kutatásunk során egy komplex problémát szeretnék elemezni, ezért a variancia- (PLS) alapú modellezést használatuk. A variancia alapú modellezés mellett a marketing területén több esetben is a kovariancia alapú (CSSEM) modellezést használják, ezért a tényleges elemzés elvégzése előtt szeretnénk a két 
módszert bemutatni, és a köztük levő különbségeket összefoglalni, valamint módszertani választásunkat alátámasztani.

Már a módszerek elnevezése is utal a felhasznált adatokra: a kovariancia alapú modellezés a kovarianciából, vagyis a változók együttmozgásából indul ki, míg a variancia alapú modellezés a változók varianciájából. Bármely variancia három részre bontható: a közös varianciára, az egyéni / specifikus varianciára, valamint a hibatagra. A kovariancia alapú modellezéseknél csak a közös variancia kerül elemzésre - a kovariancia is ezen alapszik -, míg a PLS-SEM esetében a variancia mindhárom fajtáját figyelembe veszik. A megfelelő elemzési módszer kiválasztásakor tehát már azt is figyelembe kell venni, hogy fontos-e a modell szempontjából az egyéni variancia. Amennyiben ennek nincs jelentősége a CB-SEM használata kiváló megoldásnak számíthat, ellenkező esetben azonban csak a PLS-SEM alkalmazása célszerü.

A kovariancia alapú elemzéskor (pl. LISREL, AMOS) a mérési modellek a következőképpen alakulnak:

$\mathrm{y}=\Lambda_{\mathrm{y}} \eta+\varepsilon$

$\mathrm{x}=\Lambda_{\mathrm{x}} \xi+\delta$, ahol

$\xi-a$ nem megfigyelt, látens független (exogén) változó;

$\eta$ - a nem megfigyelt, látens függö (endogén) változó;

$X-a$ látens exogén változó indikátorai;

$Y$ - a látens endogén változó indikátorai;

$\Lambda_{x}$ - a független változó faktorsúlyai;

$\Lambda_{y}$ - a függö változó faktorsúlyai;

$\delta$ - a megfigyelt független változó / exogén változó indikátorainak mérési hibája;

$\varepsilon$ - a megfigyelt függö változó / endogén változó indikátorainak mérési hibája.

A manifeszt változó tehát felbontható egy szisztematikus komponensre, valamint hibatagra. A strukturális modell ebben az esetben:

$\mathrm{B} \eta=\Gamma \xi+\zeta$, ahol

$B$ - a látens függö változók egymás közti regressziós együtthatói.

$\beta_{i j}$ - a j-edik endogén változó i-edik endogén változóra kifejtett közvetlen hatását mutatja az elöjel megfordításával.

$\Gamma$ - a független látens változó függö látensre vonatkozó regressziós együtthatóinak mátrixa.

$\gamma_{i j}$ - a j-edik exogén változó i-edik endogén változóra gyakorolt közvetlen hatása.

$\zeta$ - a strukturális modell hibaváltozója.

Ezzel szemben a variancia alapú modellezésnél (pl. LVPLS, SmartPLS) nem faktoranalitikus modellel, hanem regresszió alapúval dolgozunk, melyet súlymodellnek nevezünk. Ebben az esetben a mérési modell a következőképpen alakul: 
$y=\Lambda \eta+\varepsilon$, ahol

$Y$ - a megfigyelt manifeszt változók halmaza;

$\eta$ - a nem megfigyelt, látens változók halmaza;

$\Lambda$ - az endogén manifeszt változó faktorsúlyai;

$\varepsilon-a z$ endogén manifeszt változó mérési hibája.

A strukturális egyenlet, mely a változók közti utakat jelöli:

$\eta=\mathrm{B} \eta+\zeta$, ahol

$B$ - útegyütthatók;

$\zeta$ - az endogén látens változó sztochasztikus hibatagjai.

A strukturális egyenlet redukált formája a következőképpen alakul: $\eta=(\mathrm{I}-\mathrm{B})^{-1} \zeta=\mathrm{B}^{*} \zeta$, ahol $\mathrm{B}^{*}$ a látens változók egymásra gyakorolt teljes hatását tartalmazza.

A PLS esetében meghatározunk egy súlymodellt is, melyben a látens változót a megfigyelt változó regressziós függvényeként állítjuk elö:

$\eta=\Omega y+\delta$, ahol

$\Omega-a z$ exogén manifeszt változó regressziós súlyai;

$\delta$ - az exogén látens változó sztochasztikus hibatagjai.

A PLS algoritmus iteratív módon becsli a látens változók értékeit a külső és belső kapcsolatok alapján, egészen addig, amíg a két kapcsolat konvergens nem lesz. Azért hívják PLS-nek, mivel minden egyes becslési lépéssel a reziduális varianciát csökkenti vagy csak a külső, vagy csak a belső modellben. A CB-SEM ezzel szemben úgy becsli a paramétereket, hogy a becsült kovarianciamátrixot közelíti a megfigyelt kovarianciamátrixhoz. Feltétele, hogy a változók normális eloszlást kövessenek. Többnyire elmélettesztelésre használják, ahol a fö cél a paraméterek értékelése (Hsu, Chen és Hsieh, 2006). Ezzel szemben a variancia alapú elemzések az endogén változók hibájának minimalizálására törekednek, és előrejelzésre alkalmasak.

A variancia és kovariancia alapú módszereket összehasonlítva (8. táblázat) megállapítható, hogy az utóbbinak szigorúbb megkötései vannak az adatokkal kapcsolatban: normális eloszlást vár el, valamint a megfigyelt változóknak függetlennek kell lenniük (Hsu et al., 2006). Mintanagyság tekintetében a CB-SEM több százas mintát igényel. A PLS-hez szükséges mintanagyságról számos vita alakult ki: sokan úgy gondolják, hogy kisebb minta is elég (10-szer akkora mintanagyság, mint amennyi az indikátorok maximális száma), azonban mások véleménye szerint a statisztikailag szignifikáns eredmények érdekében a CB-SEM-hez hasonló elvárásokkal állunk szemben (Henseler et al., 2009). 
Egyesek véleménye szerint a CB-SEM inkább a csak reflektív kapcsolatok elemzésére jó, és formatív esetben számos problémával találkozhatunk. Vannak, akik viszont a PLS eredményeivel szemben elfogultak, és nekik fontos szem előtt tartani, hogy direkt statisztikai tesztre nem alkalmas (következtetések csak bootstrapping eljárással, illetve jackkneif eljárással lehetségesek). Emellett a loadingok túlbecsültek, az útegyütthatók pedig alábecsültek (Chin et al., 1996). Az illeszkedés jóságára csak a CB-SEM modellekben van mutató $(\mathrm{RMSE}<=0,05 ; \mathrm{GFI}>=0,9 ; \mathrm{CFI}>=0,9)$, mivel a PLS esetében a cél, hogy minimalizálja a megfigyelt és becsült változók kovarianciamátrixa közötti különbséget (Hsu et al., 2006).

\begin{tabular}{|l|l|l|}
\hline Elvárás & PLS & CB-SEM \\
\hline Célja & Elörejelzés orientált & Paraméter orientált \\
\hline Eljárás & Variancia alapú & Kovariancia alapú \\
\hline Elöfeltétel & $\begin{array}{l}\text { A mutatók specifikálása (nem } \\
\text { parametrikus) }\end{array}$ & $\begin{array}{l}\text { Normális eloszlás és } \\
\text { független megfigyelés } \\
\text { (parametrikus) }\end{array}$ \\
\hline Paraméterbecslés & $\begin{array}{l}\text { Minél több változó van, annál } \\
\text { több paraméter kell }\end{array}$ & Konzisztens \\
\hline $\begin{array}{l}\text { Látens változók } \\
\text { értéke }\end{array}$ & Explicit becsült & Határozatlan \\
\hline Modell komplexitás & $\begin{array}{l}\text { Nagy (pl. 100 elméleti } \\
\text { fogalomhoz 1000 indikátor) }\end{array}$ & $\begin{array}{l}\text { Kicsi (kevesebb, mint 100 } \\
\text { indikátor) }\end{array}$ \\
\hline Minta méret & $\begin{array}{l}\text { Minimum elemszám 30-100 } \\
\text { között van. A mutatóktól függ. }\end{array}$ & $\begin{array}{l}\text { Minimum elemszám 200-800 } \\
\text { között. }\end{array}$ \\
\hline
\end{tabular}

\section{8. táblázat: A PLS és a CB-SEM jellemzői}

Forrás: Chin-Newsted (1999)

A PLS alkalmas a komplex modellek magyarázatára, míg a CB-SEM-ben számos mutató értéke csökken, amint a modell komplexitása nő. Boomsma és Hoogland (2001, in: Henseler, Ringle és Sinkovics, 2009) bebizonyították, hogy minél több paramétert tartalmaz a modell, annál inkább nő a nemkonvergens és a helytelen megoldások száma, vagyis minél összetettebb a modell, annál több információra van szükség, ezáltal ez is az elvárt mintaelemszámot befolyásolja. A PLS modellezés egy új formatív látens változó bevezetése esetén robosztusnak mutatkozik a CB-SEM-mel szemben, és ugyanez jellemző az aszimmetrikus adatok esetében (Vilares et al., 2009, in: Henseler, Ringle és Sinkovics, 2009).

A kovariancia alapú modellezés és a variancia alapú azonban inkább egymást kiegészítő eljárások, mintsem versenytársak (19. ábra). Jöreskog (1982) véleménye szerint a CBSEM inkább elméletorientált, és egy átmenetet hangsúlyoz az exploratív elemzésből a konfirmatívba, míg a PLS inkább ok-okozati, előrejelző/jósló szituációkban 
alkalmazandó, amikor is a modell elég komplex, és elméletileg kevés információ áll rendelkezésre. Tehát a CB-SEM inkább elmélettesztelő, mintsem építő, míg a PLS a függő változók magyarázott varianciáját maximalizálja, ezért inkább előrejelző jellegü (Henseler et al., 2009). A variancia alapú modellezés inkább a hipotézisek, nem pedig teljes modellek tesztelésére alkalmas, illetve alacsony szintü becslést is biztosít, így inkább a mechanizmusok megértésében segít. A legújabb kutatások mégis azt támasztják alá, hogy a variancia alapú modellezés is alkalmas teljes strukturális modellek tesztelésére (Hair et al., 2011; Henseler - Sarstedt, 2012).

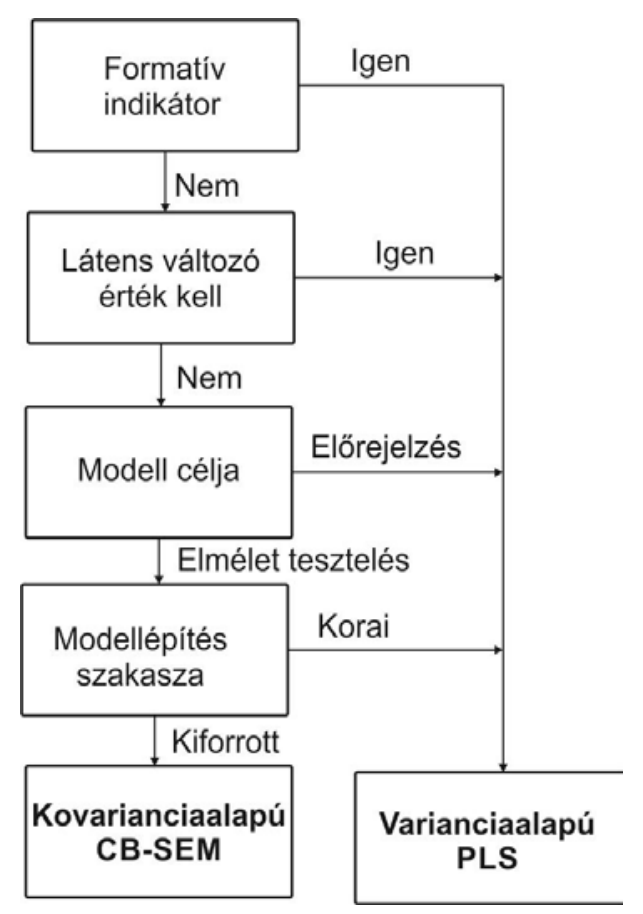

\section{9. ábra: A SEM módszertan használatának folyamatábrája}

Forrás: Hsu, Chen és Hsieh (2006)

A strukturális modellezéskor mindig két elmélet tesztelésére kerül sor: első körben a mérési elméletet teszteljük, vagyis hogy az alkalmazott változócsoportok (skálák) megfelelőek-e, és ezután térhetünk ki a tényleges struktúra, a megalkotott modell tesztelésére.

A mérési modell tesztelésekor a látens változók érvényességét és megbízhatóságát teszteljük, vagyis ellenőrizzük a belső megbízhatóságot (internal consistency reliability), az indikátor megbízhatóságát, a hasonlósági érvényességet (convergence validity), valamint a különbözőségi érvényességet (discriminant validity). 
A belső megbízhatóságot a Cronbach-alfa, illetve PLS-SEM esetében a DillonGoldstein-féle Rho mutatóval mérhetjük. A látens változókhoz tartozó hasonlósági érvényesség az átlagos magyarázott variancia értékkel (AVE) mérhető, amely megmutatja, hogy „a skála és ugyanannak a fogalomnak más mérési tételei között mennyiben áll fenn pozitív korreláció” (Malhotra - Simon, 2009 320. old). Fornell és Larcker (1981) véleménye alapján 0,5 felett fogadható el az érték.

A különbözőségi érvényesség megmutatja, hogy a skála nem korrelál-e más fogalmak kérdéseivel. Ennek ellenőrzésére a Fornell-Larcker-kritériumot használjuk, mely szerint egy adott látenshez tartozó AVE magasabb kell, hogy legyen, mint a bármely más látenssel alkotott korrelációs négyzetösszeg. Amennyiben a feltétel nem teljesül, az eredmények javítása érdekében a legalacsonyabb faktorsúllyal rendelkező mérési tételeket törölni kell.

Elemzésünk során végül a kovariancia és variancia alapú modellezések közül mi a variancia alapút választottuk, ugyanis ennek a módszernek nem feltétele a vizsgálatba bevont változók normális eloszlása, és a Kolmogorov-Smirnov próba alapján a normál eloszlástól különböző eloszlással találkozunk kutatásunk során. Emellett a modell komplexitásával a CB-SEM esetében számos mutató értéke gyengül, mely tény szintén a PLS-SEM alkalmazása mellett szól. 


\section{A MEGVALÓSÍTOTT KUTATÁSOK ÉRTÉKELÉSE}

\subsection{A nagymintás online, kérőíves kutatása}

\subsubsection{Az alkalmazott módszertan}

A felvázolt kutatási kérdések megválaszolására 2014 tavaszán online kérdőíves megkérdezést hajtottunk végre egy online panelt felhasználva. A mintaelemszámot 1.000 föben határoztuk meg, és kvótás mintavételt alkalmaztunk. Az alapsokaság az adatfelvétel előtti három hónap során online vásárlók, továbbá a minta felét alkották azok az egyének, akik valamilyen offline-terméket vagy szolgáltatást vásároltak, míg a másik felét az elektronikus-terméket vagy szolgáltatást vásárlók (9. táblázat).

\begin{tabular}{|l|c|l|c|}
\hline Neme & $43,5 \%$ & Budapest & $30,6 \%$ \\
\hline Férfi & $56,5 \%$ & megyeszékhely & $23,7 \%$ \\
\hline Nő & & egyéb nagyváros & $13,7 \%$ \\
\hline Korcsoport & $9,4 \%$ & falu & $31,6 \%$ \\
\hline $17-29$ éves & $26,4 \%$ & egyéb & $0,4 \%$ \\
\hline $30-39$ éves & $20,1 \%$ & Családi állapot & $13,4 \%$ \\
\hline $40-49$ éves & $19,9 \%$ & egyedülálló & $21,8 \%$ \\
\hline $50-59$ éves & $23,7 \%$ & párkapcsolatban él & $45,1 \%$ \\
\hline 60 év feletti & 46,83 év & házas & $8,8 \%$ \\
\hline Átlagéletkor & $0,6 \%$ & elvált & $3,6 \%$ \\
\hline Legmagagasabb iskolai végzettség & $6,4 \%$ & ólettársi kapcsolatban él & $7,3 \%$ \\
\hline általános iskola & $36,3 \%$ & Háztartás típusa & $9,7 \%$ \\
\hline szakiskola, szakmunkásképzö & $28,7 \%$ & szülökkel együtt & $1,1 \%$ \\
\hline középiskola & $26,7 \%$ & szülökkel, nagyszülökkel együtt & $1,4 \%$ \\
\hline föiskola & & $\begin{array}{l}\text { kortársaimmal együtt (közös } \\
\text { lakásbérlés) }\end{array}$ & $14,0 \%$ \\
\hline egyetem & $5,3 \%$ & egyedül & $30,9 \%$ \\
\hline Jövedelmi helyzet & $26,9 \%$ & partnerrel gyerek nélkül & $33,7 \%$ \\
\hline $\begin{array}{l}\text { Arra sem elég a havi jövedelmem/ünk, } \\
\text { hogy az alapvetö dolgokat megvegyem/ük }\end{array}$ & $54,4 \%$ & partnerrel gyerekkel & $6,7 \%$ \\
\hline $\begin{array}{l}\text { Az alapvetö dolgokat meg tudom/juk } \\
\text { vásárolni, de másra nincs. }\end{array}$ & $13,4 \%$ & partner nélkül gyerekkel & $2,5 \%$ \\
\hline $\begin{array}{l}\text { Meg tudom/juk váśrolni az alapvetö } \\
\text { dolgokat és egy-két extrát }\end{array}$ & $236528 \mathrm{Ft}$ & egyéb & \\
\hline $\begin{array}{l}\text { Könnyedén meg tudom/juk vásárolni, amire } \\
\text { szükségem/ünk van }\end{array}$ & & & \\
\hline Átlagos havi jövedelem (N=645 fö) & &
\end{tabular}

\section{9. táblázat: A nagymintás kutatási minta demográfiai jellemző}

Forrás: saját eredmények alapján saját szerkesztés

A kérdőív kérdéseinek többsége egy konkrét, az utolsó három hónapban történt vásárlási szituációra vonatkozott, melyekkel a korábban bemutatott skálákat felhasználva a használt webshoppal kapcsolatos minőségészlelést, elégedettséget, továbbajánlási és újravásárlási szándékot mértük. A kérdőív többi kérdése a válaszadói profil 
megrajzolásában segített, melynek során a válaszadók általános online vásárlási szokásait, valamint demográfiai jellemzőit gyűjtöttük össze.

A megkérdezetett többsége nő volt (56,5\%), átlagos életkoruk 46,83 év (szórás=13,39). Többségük valamilyen felsőfokú végzettséggel rendelkezik (55,4\%), és a megkérdezettek 30,6\%-a él a fövárosban. A minta végzettség, illetve település szerinti összetétele közel azonos képet mutat a GKIdigital 2014-es adataival ${ }^{6}$, mely szerint a felsőfokú végzettséggel rendelkező online vásárlók aránya 49\%-os, míg a budapestieké 27\%-os (http://www.gkidigital.hu/wp-content/uploads/2014/10/GKI-

Digital_IG_eker_2014.jpg).

A válaszadóink többsége a jövedelméből kényelmesen megél, sőt extrákra is tud küldeni (67,8\%). A megkérdezettek 64,5\%-a jelölte meg a háztartása átlagos jövedelmét: ők átlagosan 236.528,37 Ft-ból gazdálkodnak egy hónapban (szórás=126.310,87 Ft, max= $800.000,00 \mathrm{Ft})$.

A megkérdezettek többsége havi rendszerességgel szokott online vásárolni $(32,8 \%)$, ennél gyakrabban mindössze 19,3\% vásárol az interneten (20. ábra). A megkérdezettek 16,7\%-a vásárol ritkábban, mint 4 havonta online.

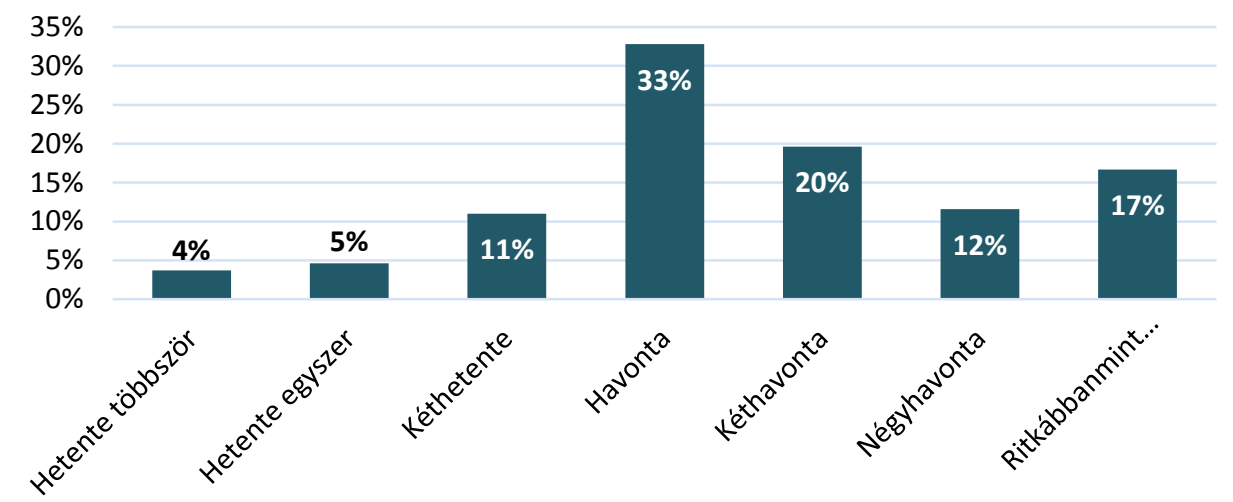

\section{0. ábra: Az online vásárlás gyakorisága ( $\mathrm{N}=1.000$ fö)}

Forrás: saját eredmények alapján saját szerkesztés

A kutatás tárgyát képező vásárlást a megkérdezettek fele a megkérdezés előtti 2 hétben valósította meg (49,5\%), tehát mondhatjuk, hogy a többségnek egy friss élményt kellett felidéznie. A vásárlás során elköltött átlagos pénzösszeg 35.210 Ft (szórás=234.713,16

${ }^{6}$ Az eredményeket kéthavonta, 1.500-2.000 az adott hónapban biztosan vásárló egyén válaszai alapján állították össze. 
Ft). A legnagyobb költés 6.000.000 Ft volt (részvényvásárlás), és jellemzően az egyéb magasabb, $200.000 \mathrm{Ft}$ feletti költések is valamilyen részvény, kötvény vagy utazás vásárlásához köthetőek, míg a legalacsonyabbak valamilyen banki szolgáltatáshoz. A vizsgált vásárlás mindössze a megkérdezettek $2 \%$-ának volt az első online vásárlása, 61,1\%-uk az elemzett vásárlás előtti egy hónapon belül vásárolt utoljára online (10. táblázat).

\begin{tabular}{|c|c|c|c|}
\hline \multicolumn{2}{|c|}{ Mennyi idő telt el az elemzett vásárlása óta?* } & \multicolumn{2}{|c|}{ Ezt megelözően mikor vásárolt utoljára?* } \\
\hline Maximum 1 hét & $31,8 \%$ & Maximum 1 hét & $18,8 \%$ \\
\hline $8-14$ nap & $17,7 \%$ & $8-14$ nap & $10,3 \%$ \\
\hline 15-30 nap & $29,9 \%$ & $15-30$ nap & $30,8 \%$ \\
\hline 31-60 nap & $14,2 \%$ & 31-60 nap & $19,8 \%$ \\
\hline 61-90 nap & $6,4 \%$ & 61-90 nap & $6,8 \%$ \\
\hline Átlag (nap) & 22,21 & 91-180 napja & $8,4 \%$ \\
\hline Szórás (nap) & 22,56 & 180-365 napja & $2,5 \%$ \\
\hline \multicolumn{2}{|c|}{$\begin{array}{l}\text { Mennyibe került a vásárolt termék / } \\
\text { szolgáltatás? }\end{array}$} & Több mint 1 éve & $0,7 \%$ \\
\hline Átlag & $35.210,00 \mathrm{Ft}$ & Ez volt az első vásárlásom & $1,9 \%$ \\
\hline Szórás & $234.713,16 \mathrm{Ft}$ & Átlag (nap) & 45,61 \\
\hline Minimum költés & $10,00 \mathrm{Ft}$ & Szórás (nap) & 60,473 \\
\hline Maximum költés & $6.000 .000 \mathrm{Ft}$ & $\begin{array}{l}\text { *A kérdések arány skálán kerültek mérésre, } \\
\text { kialakitva. }\end{array}$ & utólag lettek \\
\hline
\end{tabular}

\section{0. táblázat: A kutatás középpontjában álló online vásárlás leíró jellemzői} ( $\mathbf{N}=\mathbf{1 . 0 0 0}$ fö)

Forrás: saját eredmények alapján saját szerkesztés

Azok, akik valamilyen offline-terméket vagy szolgáltatás vásároltak az interneten - tehát olyan jószágot vettek online, melynek kézhezvétele és/vagy elfogyasztása nem a virtuális térben, hanem az „offline világban” történik - a legtöbben valamilyen müszaki vagy szórakozástechnikai cikket (14,6\%), könyvet, újságot, magazint (13\%) vagy ruházatot, sporteszközt, ékszert (11,8\%) vásárolt. Az 500 megkérdezett közül a többség valamilyen terméket vásárolt $(73 \%)$.

Az elektronikus-terméket/szolgáltatást vásárlók körében kiegyensúlyozottan alakult a terméket és szolgáltatást vásárlók aránya (47\% és 53\%). A megkérdezettek többsége $(19,8 \%)$ valamilyen szolgáltató oldalán regisztrált vagy hajtott végre tranzakciót (randi, online TV, e-banking), vagy online kötött biztosítást (18\%) (11 .táblázat). 


\begin{tabular}{|c|c|c|c|c|c|}
\hline \multicolumn{3}{|c|}{$\begin{array}{c}\text { A vásárolt jószág jellege (offline } \\
\text { termékek/szolgáltatások csoportja) }\end{array}$} & \multicolumn{3}{|c|}{$\begin{array}{l}\text { A vásárolt jószág jellege (online } \\
\text { termékek/szolgáltatások csoportja) }\end{array}$} \\
\hline $\begin{array}{l}\text { Szórakoztató technika, müszaki } \\
\text { cikkek }\end{array}$ & $\mathrm{T}$ & $14,6 \%$ & $\begin{array}{l}\text { Valamilyen szolgáltatói felületen } \\
\text { történő regisztráció (pl. e-banking) }\end{array}$ & SZ & $19,8 \%$ \\
\hline Könyv, újság, vagy magazin & $\mathrm{T}$ & $13,0 \%$ & $\begin{array}{l}\text { Biztosításkötés kizárólag az online } \\
\text { felületet felhasználv }\end{array}$ & $\mathrm{SZ}$ & $18,0 \%$ \\
\hline Ruházat, sporteszközök, ékszer & $\mathrm{T}$ & $11,8 \%$ & E-könyv, e-újság, vagy e-magazin & $\mathrm{T}$ & $15,0 \%$ \\
\hline $\begin{array}{l}\text { Számítástechnikai berendezés, } \\
\text { eszköz }\end{array}$ & $\mathrm{T}$ & $7,6 \%$ & Szoftver vagy valamilyen applikáció & $\mathrm{T}$ & $13,6 \%$ \\
\hline Szállás & SZ & $7,6 \%$ & Letölthető videojáték & $\mathrm{T}$ & $7,4 \%$ \\
\hline Utazás, repülőjegy & SZ & $7,0 \%$ & Film-, zeneletöltés pénzért & $\mathrm{T}$ & $4,6 \%$ \\
\hline Háztartási berendezés & $\mathrm{T}$ & $6,2 \%$ & $\begin{array}{l}\text { Valamilyen online kurzusra történő } \\
\text { regisztráció }\end{array}$ & SZ & $3,6 \%$ \\
\hline Kozmetikumok & $\mathrm{T}$ & $5,8 \%$ & Online tőzsde, részvényvásárlás & SZ & $2,6 \%$ \\
\hline $\begin{array}{l}\text { Kozmetikai szolgáltatás, } \\
\text { sportolási lehetőség }\end{array}$ & $\mathrm{SZ}$ & $4,2 \%$ & Egyéb online-terméket & $\mathrm{T}$ & $6,8 \%$ \\
\hline Élelmiszer & $\mathrm{T}$ & $3,6 \%$ & Egyéb online-szolgáltatást & SZ & $8,6 \%$ \\
\hline Meleg étel & SZ & $3,4 \%$ & & & \\
\hline $\begin{array}{l}\text { Mozi-, színházjegy, vagy egyéb } \\
\text { belépô }\end{array}$ & $\mathrm{SZ}$ & $3,2 \%$ & & & \\
\hline $\begin{array}{l}\text { Film, zene, videójáték CD-n, } \\
\text { DVD-n }\end{array}$ & $\mathrm{T}$ & $1,2 \%$ & & & \\
\hline Egyéb termék & $\mathrm{T}$ & $9,4 \%$ & & & \\
\hline Egyéb szolgáltatás & SZ & $1,4 \%$ & & & \\
\hline
\end{tabular}

11. táblázat: A kutatás középpontjában álló online vásárlás leíró jellemzői (N=500-500 fö)

Forrás: saját eredmények alapján saját szerkesztés

\subsubsection{Az e-kereskedelemi csoportok közti eltérések}

Mivel a szakirodalmi összefoglalóban meghatározott négy e-kereskedelmi kategória vagyis az offline-terméket, offline-szolgáltatást, e-terméket, e-szolgáltatást vásárlók köre - kiemelt szereppel bír a kutatásunk során, ezért e szegmenseket részletesen is megvizsgáltuk.

Az 1.000 fős mintából az értékelt vásárlás során 366 fő vett valamilyen offline-terméket, 134 fő pedig valamilyen offline-szolgáltatást. Az e-terméket vásárlók száma 237, míg az e-szolgáltatásokat vásárlók 263-an vannak. Demográfiai jellemzők tekintetében az offline-terméket vásárlók körében magasabb a férfiak aránya (53,6\%) és ez számít a „legfiatalabb” szegmensnek (átlagéletkorOT=44,71), bár a többi szegmens átlagos életkora is 50 év alatt van. Az összes többi kategóriában a nők dominálnak. Az iskolai végzettséget tekintve az e-szolgáltatást vásárlók körében magasabb a felsőfokú végzettséggel rendelkezők aránya (64,2\%), míg az offline-terméket vásárlók körében kiugróan magas a falun élők aránya (39,1\%). Az átlagos háztartási jövedelem esetében nincs szignifikáns 
különbség a szegmensek között. Ezek alapján megállapítható, hogy a különböző ekereskedelmi szegmensekbe tartozó almintáink nem rendelkeznek extrémen különböző tulajdonságokkal (12. táblázat).

\begin{tabular}{|c|c|c|c|c|c|}
\hline & $\begin{array}{l}\text { Offline- } \\
\text { terméket } \\
\text { vásárlók } \\
(\mathrm{N}=366 \text { fó) } \\
\end{array}$ & $\begin{array}{l}\text { Offline- } \\
\text { szolgáltatást } \\
\text { vásárlók } \\
(\mathrm{N}=134 \text { fó }) \\
\end{array}$ & $\begin{array}{l}\text { E-terméket } \\
\text { vásárlók } \\
\text { (N=273 fó) }\end{array}$ & $\begin{array}{l}\text { E-szolgáltatást } \\
\text { vásárlók } \\
(\mathrm{N}=263 \text { fó) }\end{array}$ & $\begin{array}{c}\text { Teljes } \\
\text { minta } \\
(\mathbf{1 0 0 0} \text { fó) }\end{array}$ \\
\hline \multicolumn{6}{|l|}{ Neme } \\
\hline Férfi & $53,6 \%$ & $40,3 \%$ & $38,4 \%$ & $35,7 \%$ & $43,5 \%$ \\
\hline Nő & $46,4 \%$ & $59,7 \%$ & $61,6 \%$ & $64,3 \%$ & $56,5 \%$ \\
\hline Pearson Chi2 p-érték & 0,000 & & & & \\
\hline \multicolumn{6}{|l|}{ Átlagéletkor } \\
\hline Átlag & 44,71 év & 49,25 év & 47,76 év & 47,71 év & 46,83 év \\
\hline Szórás & 13,39 év & 13,55 év & 13,21 év & 13,16 év & 13,39 év \\
\hline F-próba p-érték & 0,001 & & & & \\
\hline \multicolumn{6}{|c|}{ Legmagasabb iskolai végzettség } \\
\hline általános iskola & $1,1 \%$ & $0,7 \%$ & $0,4 \%$ & $0,0 \%$ & $0,6 \%$ \\
\hline $\begin{array}{l}\text { szakiskola, } \\
\text { szakmunkásképző }\end{array}$ & $9,0 \%$ & $6,7 \%$ & $3,4 \%$ & $5,3 \%$ & $6,4 \%$ \\
\hline középiskola & $39,9 \%$ & $35,1 \%$ & $39,2 \%$ & $29,3 \%$ & $36,3 \%$ \\
\hline föiskola & $27,6 \%$ & $29,1 \%$ & $28,7 \%$ & $30,0 \%$ & $28,7 \%$ \\
\hline egyetem & $21,0 \%$ & $26,9 \%$ & $27,0 \%$ & $34,2 \%$ & $26,7 \%$ \\
\hline Pearson Chi2 p-érték & 0,029 & & & & \\
\hline \multicolumn{6}{|l|}{ Jövedelmi helyzet } \\
\hline $\begin{array}{l}\text { Arra sem elég a havi } \\
\text { jövedelmem/ünk, hogy } \\
\text { az alapvető dolgokat } \\
\text { megvegyem/ük }\end{array}$ & $5,2 \%$ & $6,0 \%$ & $5,1 \%$ & $5,3 \%$ & $5,3 \%$ \\
\hline $\begin{array}{l}\text { Az alapvető dolgokat } \\
\text { meg tudom/juk } \\
\text { vásárolni, de másra } \\
\text { nincs }\end{array}$ & $29,0 \%$ & $26,1 \%$ & $27,4 \%$ & $24,0 \%$ & $26,9 \%$ \\
\hline $\begin{array}{l}\text { Meg tudom/juk } \\
\text { vásárolni az alapvető } \\
\text { dolgokat és egy-két } \\
\text { extrát }\end{array}$ & $56,3 \%$ & $53,7 \%$ & $53,6 \%$ & $52,9 \%$ & $54,4 \%$ \\
\hline $\begin{array}{l}\text { Könnyedén meg } \\
\text { tudom/juk vásárolni, } \\
\text { amire szükségem/ünk } \\
\text { van }\end{array}$ & $9,6 \%$ & $14,2 \%$ & $13,9 \%$ & $17,9 \%$ & $13,4 \%$ \\
\hline Pearson Chi2 p-érték & 0,344 & & & & \\
\hline \multicolumn{6}{|l|}{ Átlagos havi jövedelem } \\
\hline Átlag & $226.710 \mathrm{Ft}$ & $235.029 \mathrm{Ft}$ & $244.353 \mathrm{Ft}$ & $250.998 \mathrm{Ft}$ & $236.528 \mathrm{Ft}$ \\
\hline Szórás & $113235 \mathrm{Ft}$ & $137.368 \mathrm{Ft}$ & $143.230 \mathrm{Ft}$ & $130.313 \mathrm{Ft}$ & $126.310 \mathrm{Ft}$ \\
\hline F-próba p-érték & 0,238 & & & & \\
\hline \multicolumn{6}{|l|}{ Településtípus } \\
\hline Budapest & $20,2 \%$ & $43,3 \%$ & $31,2 \%$ & $38,0 \%$ & $30,6 \%$ \\
\hline megyeszékhely & $24,0 \%$ & $16,4 \%$ & $25,3 \%$ & $25,5 \%$ & $23,7 \%$ \\
\hline egyéb nagyváros & $16,1 \%$ & $14,2 \%$ & $13,5 \%$ & $10,3 \%$ & $13,7 \%$ \\
\hline falu & $39,1 \%$ & $26,1 \%$ & $29,1 \%$ & $26,2 \%$ & $31,6 \%$ \\
\hline egyéb & $0,5 \%$ & $0,0 \%$ & $0,8 \%$ & $0,0 \%$ & $0,4 \%$ \\
\hline Pearson Chi2 p-érték & 0,000 & & & & \\
\hline
\end{tabular}

\section{2. táblázat: Az elemzett e-kereskedelmi csoportok vásárlóinak demográfiai jellemzői ( $N=366 / 134 / 273 / 263 / 1000$ fó)}

Forrás: saját eredmények alapján saját szerkesztés 
$\mathrm{Az}$ online vásárlás gyakoriságát tekintve szignifikáns különbség figyelhető meg az offline-jószágot, illetve elektronikus-jószágot vásárlók körében (Pearson $\mathrm{Chi}^{2}$ $\operatorname{sig}=0,000)$. Az utóbbi csoportban magasabb a legalább havonta vásárlók aránya: az eterméket vásárlók 64\%-a vásárol legalább havonta az interneten, az e-szolgáltatást vásárlók esetében pedig $63 \%$.

A legnépszerübb offlinetermék-csoport a szórakoztató technika (73 fó, 19,9\%), a legnépszerübb offline-szolgáltatás pedig a szálláshely (38 fö, 28,3\%). Az elektronikus leszállított és elfogyasztott terméket vásárlók közül a legtöbben e-könyvet, e-magazint vásároltak (75 fö, 31,6\%), míg az e-szolgáltatások közül a legpopulárisabb a szolgáltató felületén történő regisztráció (99 fö, 37,6\%).

Legmagasabb értékben átlagosan az e-szolgáltatást vásárlók költöttek (átlag $\mathrm{ESz}_{2}=77.248$ Ft, szórás Esz $=442.212 \mathrm{Ft}$ ), mely költéstől szignifikánsabb alacsonyabb az offline-terméket és e-termékeket vásárlók átlagos költése. Az offline-szolgáltatást vásárlók átlagos költése 44.212 Ft (szórásot=126.843 Ft). A részletes adatokat a 13. táblázat tartalmazza. Ezek alapján megállapíthatjuk, hogy a szolgáltatások esetében az átlagos költés magasabb az elemzett vásárlások esetében.

\begin{tabular}{|c|c|c|c|c|c|}
\hline & $\begin{array}{l}\text { Offline- } \\
\text { terméket } \\
\text { vásárlók } \\
(\mathrm{N}=\mathbf{3 6 6 \text { fó } )}\end{array}$ & $\begin{array}{l}\text { Offline- } \\
\text { szolgáltatást } \\
\text { vásárlók } \\
(\mathrm{N}=134 \text { fó })\end{array}$ & $\begin{array}{c}\mathrm{E}- \\
\text { terméket } \\
\text { vásárlók } \\
(\mathrm{N}=273 \mathrm{fó})\end{array}$ & $\begin{array}{c}\text { E- } \\
\text { szolgáltatás } \\
\text { t vásárlók } \\
(\mathrm{N}=263 \text { fó) }\end{array}$ & $\begin{array}{l}\text { Teljes } \\
\text { minta } \\
(\mathbf{1 0 0 0} \text { fó) }\end{array}$ \\
\hline \multicolumn{6}{|c|}{ Milyen gyakran szokott az interneten vásárolni? } \\
\hline Hetente többször & $0,8 \%$ & $2,2 \%$ & $5,9 \%$ & $6,5 \%$ & $3,7 \%$ \\
\hline Hetente egyszer & $2,5 \%$ & $6,0 \%$ & $5,1 \%$ & $6,5 \%$ & $4,6 \%$ \\
\hline Kéthetente & $6,6 \%$ & $9,0 \%$ & $14,3 \%$ & $15,2 \%$ & $11,0 \%$ \\
\hline Havonta & $30,1 \%$ & $26,9 \%$ & $38,4 \%$ & $34,6 \%$ & $32,8 \%$ \\
\hline Kéthavonta & $24,6 \%$ & $24,6 \%$ & $11,4 \%$ & $17,5 \%$ & $19,6 \%$ \\
\hline Négyhavonta & $14,8 \%$ & $12,7 \%$ & $9,7 \%$ & $8,4 \%$ & $11,6 \%$ \\
\hline $\begin{array}{l}\text { Ritkábban, mint } \\
\text { négyhavonta }\end{array}$ & $20,8 \%$ & $18,7 \%$ & $15,2 \%$ & $11,4 \%$ & $16,7 \%$ \\
\hline \multicolumn{6}{|c|}{ Mennyit költött az értékelt vásárlásakor? } \\
\hline Átlag & $17721 \mathrm{Ft}$ & $44212 \mathrm{Ft}$ & $10479 \mathrm{Ft}$ & $77248 \mathrm{Ft}$ & $35210 \mathrm{Ft}$ \\
\hline Szórás & $48076 \mathrm{Ft}$ & $126843 \mathrm{Ft}$ & $18934 \mathrm{Ft}$ & $442212 \mathrm{Ft}$ & $234713 \mathrm{Ft}$ \\
\hline
\end{tabular}

\section{3. táblázat: Az elemzett e-kereskedelmi csoportok vásárlóinak leíró jellemzői ( $\mathrm{N}=366 / 134 / 273 / 263 / 1000$ fó)}

Forrás: saját eredmények alapján saját szerkesztés

\subsubsection{Az elektronikus szolgáltatásminőség értékelése}

Az elektronikus szolgáltatásminőség részletes mérésére a Francis (2009) által létrehozott, validált RECIPE skálát használtuk. A felhasznált elmélet értelmében az e-kereskedelem a vásárolt jószág jellege, valamint a teljesítés módja alapján négy szegmensre osztható: 
az offline-termékek, offline-szolgáltatások, elektronikus-termékek és elektronikusszolgáltatások csoportjára. Az e-szolgáltatásminőség mérése során - ahogy már a szakirodalmi összefoglalóban is összegeztük - a következő látens dimenziók észlelt minőségét mérjük: (1) a webshopban fellelhető információk és instrukciók minősége, (2) a vásárlás lebonyolítása, (3) az ügyfélszolgálat elérhetősége, kommunikációja, (4) biztonság.

Francis és White (évszám) kvalitatív kutatásai alapján a dimenziókhoz tartozó manifeszt változók esetében eltérések figyelhetőek meg a négy szegmens esetében, melyek a termékek és szolgáltatások, valamint a teljesítési módok közötti különbségekből adódnak.

Elemzésünk során nemcsak az egyes manifeszt változók értékeit vizsgáltuk, hanem a megfigyelt változókra adott értékek alapján megalkottuk a dimenziók egyéni átlagait is. Az átlagszámítás során a válaszadók hiányzó értékeit figyelmen kívül hagytuk. A megfigyelt változókhoz tartozó kijelentéseket a válaszadóknak 1-től 7-ig terjedő skálán kellett értékelniük, ahol az 1-es jelölte, hogy az egyén egyáltalán nem ért egyet az adott kijelentéssel, míg a 7-es, hogy teljes mértékben egyetért vele.

\begin{tabular}{|l|c|c|c|l|c|c|c|}
\hline \multicolumn{5}{|c|}{ Offlline-termék } & \multicolumn{5}{c|}{ Offline-szolg } \\
\hline Tulajdonság & Átlag & $\mathbf{N}(\mathbf{f o ́})$ & Szórás & Tulajdonság & Atlag & N (fó) & Szórás \\
\hline WEBS_OT1 & 6,21 & 366 & 1,16 & WEBS_OSZ1 & 5,39 & 134 & 1,71 \\
\hline WEBS_OT2 & 5,84 & 366 & 1,25 & WEBS_OSZ2 & 5,40 & 134 & 1,33 \\
\hline WEBS_OT3 & 6,18 & 366 & 1,13 & WEBS_OSZ3 & 5,89 & 134 & 1,27 \\
\hline WEBS_OT4 & 6,13 & 366 & 1,17 & WEBS_OSZ4 & 5,78 & 134 & 1,23 \\
\hline Átlagolt érték & $\mathbf{6 , 0 9}$ & $\mathbf{3 6 6}$ & $\mathbf{1 , 0 0}$ & Átlagolt érték & $\mathbf{5 , 6 2}$ & $\mathbf{1 3 4}$ & $\mathbf{1 , 1 6}$ \\
\hline \multicolumn{6}{|c|}{ E-termék } \\
\hline WEBS_ET1 & 4,54 & 237 & 2,48 & WEBS_ESZ1 & 6,25 & 263 & 1,14 \\
\hline WEBS_ET2 & 5,05 & 237 & 2,27 & WEBS_ESZ2 & 6,20 & 263 & 1,22 \\
\hline WEBS_ET3 & 5,12 & 237 & 2,24 & WEBS_ESZ3 & 6,38 & 263 & 1,22 \\
\hline WEBS_ET4 & 3,67 & 237 & 2,61 & WEBS_ESZ4 & 6,26 & 263 & 1,45 \\
\hline Átlagolt érték & $\mathbf{4 , 6 0}$ & $\mathbf{2 3 7}$ & $\mathbf{1 , 9 5}$ & Átlagolt érték & $\mathbf{6 , 2 7}$ & $\mathbf{2 6 3}$ & $\mathbf{1 , 1 0}$ \\
\hline
\end{tabular}

14. táblázat: Konkrét webshopminőség értékelése (1-7 skála) $(\mathrm{N}=366 / 134 / 273 / 263$

fö)

Forrás: saját eredmények alapján saját szerkesztés ${ }^{7}$

Eredményeink alapján megállapítható (14-15. táblázat), hogy a webshop fizikai megjelenítéséhez tartozó dimenziók esetében legjobb átlagos értékeléssel az eszolgáltatások esetében találkoztunk (átlage-szolg $=6,27$, szóráse-szolg $=1,10$ ), míg leggyengébb értékelést az e-termékeket értékesítő webshopok kapták (átlage-term $=4,60$, szórás -term $=1,95$ ). Ebben a dimenzióban a legrosszabb értékelést az ingyenes/triál

\footnotetext{
${ }^{7}$ A különböző rövidítésekhez tartozó konkrét mérési változókat a 4. számú melléklet tartalmazza.
} 
változatok elérhetősége kapta (átlag e-termPROD4 $=3,67, \quad$ szóráse-termPROD4 $=2,61$ ). Többváltozós varianciaelemzést használva megállapítható, hogy a dimenzióra adott átlagos értékek 95\%-os megbízhatóság mellett az offline-termékek és az e-szolgáltatások értékelését kivéve ( $\operatorname{sig}=0,106$, delta websitequalOT-ESZ $=-0,109)$ szignifikánsan különböznek egymástól a négy különböző szegmensben.

\begin{tabular}{|c|c|c|c|c|}
\hline Függố változó & A csoport & B csoport & Különbség (I-J) & Sig. $(F-p r o ́ b a)$ \\
\hline \multirow{12}{*}{$\begin{array}{l}\text { Konkrét } \\
\text { webshopminőség } \\
\text { (átlagolt értékelés) }\end{array}$} & \multirow{3}{*}{$\begin{array}{l}\text { Offline- } \\
\text { termék }\end{array}$} & Offline-szolgáltatás &, $40^{*}$ & ,006 \\
\hline & & \begin{tabular}{|l|} 
E-termék \\
\end{tabular} & $1,63^{*}$ &, 000 \\
\hline & & \begin{tabular}{|l} 
E-szolgáltatás \\
\end{tabular} &,- 19 &, 106 \\
\hline & \multirow{3}{*}{$\begin{array}{l}\text { Offline- } \\
\text { szolgáltatás }\end{array}$} & Offline-termék &,$- 40^{*}$ &, 006 \\
\hline & & \begin{tabular}{|l|} 
E-termék \\
\end{tabular} & $1,23^{*}$ &, 000 \\
\hline & & E-szolgáltatás &,$- 60^{*}$ &, 000 \\
\hline & \multirow{3}{*}{ E-termék } & Offline-termék & $-1,63^{*}$ &, 000 \\
\hline & & Offline-szolgáltatás & $-1,23^{*}$ &, 000 \\
\hline & & E-szolgáltatás & $-1,82^{*}$ & 000 \\
\hline & \multirow{3}{*}{ E-szolgáltatás } & Offline-termék &, 19 &, 106 \\
\hline & & Offline-szolgáltatás &, $60^{*}$ &, 000 \\
\hline & & \begin{tabular}{|l|} 
E-termék \\
\end{tabular} & $1,82^{*}$ &, 000 \\
\hline
\end{tabular}

\section{5. táblázat: Konkrét webshopminőség értékelése közti különbségek az e- kereskedelmi kategóriák esetében (1-7 skála) ( $N=366 / 134 / 273 / 263$ fó)}

Forrás: saját eredmények alapján saját szerkesztés

\begin{tabular}{|l|c|c|c|l|c|c|c|}
\hline \multicolumn{5}{|c|}{ Offline-termék } & \multicolumn{5}{c|}{ Offlline-szolg } \\
\hline Tulajdonság & Átlag & $\mathbf{N}(\mathbf{f o ́})$ & Szórás & Tulajdonság & Átlag & $\mathbf{N}(\mathbf{f o ́})$ & Szórás \\
\hline EXCH1_OT1 & 6,39 & 366 & 1,09 & EXCH1_OSZ1 & 6,10 & 134 & 1,25 \\
\hline EXCH1_OT2 & 6,45 & 366 & 1,08 & EXCH1_OSZ2 & 6,17 & 134 & 1,23 \\
\hline EXCH1_OT3 & 6,35 & 366 & 1,20 & EXCH1_OSZ3 & 6,30 & 134 & 1,03 \\
\hline EXCH1_OT4 & 6,52 & 366 & 1,07 & EXCH1_OSZ4 & 6,34 & 134 & 1,06 \\
\hline EXCH1_OT5 & 6,56 & 366 & 0,94 & EXCH1_OSZ5 & 6,21 & 134 & 1,18 \\
\hline Átlagolt érték & $\mathbf{6 , 4 5}$ & $\mathbf{3 6 6}$ & $\mathbf{0 , 9 2}$ & Attagolt érték & $\mathbf{6 , 2 2}$ & $\mathbf{1 3 4}$ & $\mathbf{1 , 0 4}$ \\
\hline \multicolumn{9}{|c|}{ E-termék } \\
\hline EXCH1_ET1 & 6,07 & 237 & 1,68 & EXCH1_ESZ1 & 6,27 & 263 & 1,44 \\
\hline EXCH1_ET2 & 6,18 & 237 & 1,60 & EXCH1_ESZ2 & 6,38 & 263 & 1,17 \\
\hline EXCH1_ET3 & 6,32 & 237 & 1,35 & EXCH1_ESZ3 & 6,31 & 263 & 1,13 \\
\hline EXCH1_ET4 & 5,93 & 237 & 1,72 & EXCH1_ESZ4 & 6,32 & 263 & 1,25 \\
\hline EXCH1_ET5 & 5,86 & 237 & 1,79 & EXCH1_ESZ5 & 6,29 & 263 & 1,13 \\
\hline Átlagolt érték & $\mathbf{6 , 0 6}$ & $\mathbf{2 3 7}$ & $\mathbf{1 , 4 0}$ & EXCH1_ESZ6 & 6,29 & 263 & 1,20 \\
\hline
\end{tabular}

\section{6. táblázat: A vásárlás lebonyolításának értékelése (1-7 skála)} ( $N=366 / 134 / 273 / 263$ fó)

Forrás: saját eredmények alapján saját szerkesztés

A tényleges vásárlásra, a cserére/foglalásra és a fizetésre vonatkozó dimenzió esetében az áltagos értékelés alapján szintén az e-termékek vásárlására használt webshopok szerepeltek leggyengébben (átlage-term $=6,06$, szóráse-term=1,40), míg az offline-termékeket vásárlók értékelése a legmagasabb (átlag ${ }_{\text {off-term }}=6,45$, szórás ${ }_{\text {off-term }}=0,92$ ), mely különbség 
szignifikánsnak tekinthető ( $\operatorname{sig}_{\text {exchangeOT-ET }}=0,000$, delta $a_{\text {exchangeOT-ET }}=0,490$ ). Az etermékek vásárlására használt webshopok értékelése a vásárlás lebonyolítása szempontjából az e-szolgáltatásoktól is szignifikánsan különbözik (szigexchangeESz$\mathrm{ET}=0,001$, delta $a_{\text {exchangeESz-ET }}=0,381$, valamint az offline-termékek és offlineszolgáltatások esetében is szignifikáns különbség figyelhető meg (szigexchangeOT$\mathrm{OSz}=0,036$, delta $\left._{\text {exchangeOT-OSz }}=0,258\right)(16-17$. táblázat $)$.

\begin{tabular}{|c|c|c|c|c|}
\hline Függő változó & A csoport & B csoport & Különbség (A-B csop) & Sig. $(F-p r o ́ b a)$ \\
\hline \multirow{12}{*}{$\begin{array}{l}\text { Vásárlás } \\
\text { lebonyolításának } \\
\text { minősége (átlagolt } \\
\text { értékelés) }\end{array}$} & \multirow{3}{*}{$\begin{array}{l}\text { Offline- } \\
\text { termék }\end{array}$} & Offline-szolgáltatás &, $26^{*}$ &, 036 \\
\hline & & E-termék & $49^{*}$ & 000 \\
\hline & & E-szolgáltatás &, 11 &, 275 \\
\hline & \multirow{3}{*}{$\begin{array}{l}\text { Offline- } \\
\text { szolgáltatás }\end{array}$} & Offline-termék &,$- 26^{*}$ &, 036 \\
\hline & & E-termék &, 23 &, 084 \\
\hline & & E-szolgáltatás &,- 15 & 245 \\
\hline & \multirow{3}{*}{ E-termék } & Offline-termék &,$- 49^{*}$ &, 000 \\
\hline & & Offline-szolgáltatás &,- 23 &, 084 \\
\hline & & E-szolgáltatás &,$- 39^{*}$ &, 001 \\
\hline & \multirow{3}{*}{$\begin{array}{l}\text { E- } \\
\text { szolgáltatás }\end{array}$} & Offline-termék &,- 10 &, 275 \\
\hline & & Offline-szolgáltatás &, 15 & 245 \\
\hline & & E-termék & $39^{*}$ &, 001 \\
\hline
\end{tabular}

\section{7. táblázat: A vásárlás lebonyolításának értékelése közti különbségek az e- kereskedelmi kategóriák esetében (1-7 skála) ( $\mathrm{N}=366 / 134 / 273 / 263$ fö)}

Forrás: saját eredmények alapján saját szerkesztés

A biztonság dimenziójának tekintetében - melybe a személyes adatok és a bankkártyainformációk észlelt biztonsága tartozik ${ }^{8}$ - szintén az e-termékek webshopjai szerepeltek a leggyengébben (átlag $\mathrm{e}_{\text {-term }}=5,74$, szóráse-term $=1,64$ ), legjobban pedig az offline-

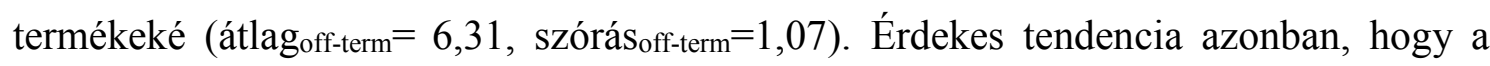
válaszadók jelentős hányada az ide tartozó állításokat nem tudta értékelni. A teljes mintában 77 olyan egyén volt, aki egyik kijelentést sem tudta értékelni, mert nem állt rendelkezésére információ adatainak biztonságáról és kezeléséről, és összesen 417 fő volt, aki legalább egy kijelentést nem tudott értékelni. Legtöbben (300 fö) a bankkártyahasználat biztonságának garantálásáról nem tudtak véleményt formálni. Mivel a nem válaszolók helyettesítése a strukturális modellezés esetében jelentős különbségeket eredményezhet, ezért az elemzésünk során a hiányzó értékekkel rendelkező válaszadókat külön vizsgáljuk. A nem válaszolók aránya a legmagasabb az offline-termékek esetében volt (197 fö, 54\%), amely nagy valószínűséggel azzal is összeköthető, hogy ezekben az

\footnotetext{
${ }^{8}$ A biztonsághoz kapcsolódó információk egyértelműen voltak elmagyarázva.

A bankkártyám/hitelkártyám biztonságát garantálták.

A személyes adatok felhasználása részletesen el volt magyarázva.

A személyes adataimat bizalmasan kezelték.
} 
esetekben sokszor az átvételkor történik a fizetés (18-19. táblázat). Ennek vizsgálata egy jelentős jövőbeli kutatási irányt jelölhet ki a téma szempontjából.

A biztonság dimenziójának értékelése esetében is megfigyelhetőek szignifikáns különbségek: az offline-terméket vásárlók értékelése minden egyéb szegmens értékeléséhez képest szignifikánsan magasabb ( $\operatorname{sig}_{\text {securityOT-OSz }}=0,009$, sig $_{\text {securityOT- }}$ $\mathrm{ET}=0,000, \operatorname{sig}_{\text {securityOT-ESz }}=0,052$ ), valamint az e-szolgáltatást vásárlók értékelése az eterméket vásárlókéhoz képest is szignifikánsan magasabb ( $\operatorname{sig}_{\text {securityET-ESz }}=0,009$ ).

\begin{tabular}{|l|c|c|c|l|l|c|c|c|}
\hline \multicolumn{5}{|c|}{ Offline-termék } & \multicolumn{5}{c|}{ Offline-szolg } \\
\hline Tulajdonság & Átlag & $\mathbf{N}(\mathbf{f o ́ )}$ & Szórás & Tulajdonság & Átlag & N (fö) & Szórás \\
\hline SEC1 & 6,19 & 285 & 1,27 & SEC1 & 6,00 & 117 & 1,23 \\
\hline SEC2 & 6,28 & 199 & 1,06 & SEC2 & 6,07 & 107 & 1,31 \\
\hline SEC3 & 6,34 & 310 & 1,08 & SEC3 & 6,08 & 118 & 1,31 \\
\hline SEC4 & 6,45 & 284 & 0,92 & SEC4 & 6,24 & 113 & 1,15 \\
\hline Attlagolt érték & $\mathbf{6 , 3 6}$ & $\mathbf{3 3 1}$ & $\mathbf{0 , 9 6}$ & Attlagolt érték & $\mathbf{6 , 0 6}$ & $\mathbf{1 2 7}$ & $\mathbf{1 , 1 5}$ \\
\hline \multicolumn{5}{|c|}{ E-termék } \\
\hline SEC1 & 5,77 & 196 & 1,76 & SEC1 & 6,15 & 213 & 1,15 \\
\hline SEC2 & 6,23 & 189 & 1,34 & SEC2 & 6,19 & 205 & 1,25 \\
\hline SEC3 & 5,96 & 200 & 1,58 & SEC3 & 6,24 & 227 & 1,19 \\
\hline SEC4 & 6,13 & 194 & 1,39 & SEC4 & 6,32 & 209 & 1,12 \\
\hline Átlagolt érték & $\mathbf{5 , 9 8}$ & $\mathbf{2 2 1}$ & $\mathbf{1 , 4 4}$ & Átlagolt érték & $\mathbf{6 , 2 2}$ & $\mathbf{2 4 4}$ & $\mathbf{1 , 1 3}$ \\
\hline
\end{tabular}

18. táblázat: Az észlelt biztonság értékelése (1-7 skála)

Forrás: saját eredmények alapján saját szerkesztés

\begin{tabular}{|c|c|c|c|c|}
\hline Függố változó & A csoport & B csoport & Különbség (A-B csop) & Sig. (F-próba) \\
\hline \multirow{12}{*}{$\begin{array}{l}\text { Biztonság (átlagolt } \\
\text { értékelés) }\end{array}$} & \multirow{3}{*}{$\begin{array}{l}\text { Offline- } \\
\text { termék }\end{array}$} & Offline-szolgáltatás &, $37^{*}$ & ,009 \\
\hline & & E-termék &, $56^{*}$ &, 000 \\
\hline & & E-szolgáltatás &, 22 & 052 \\
\hline & \multirow{3}{*}{$\begin{array}{l}\text { Offline- } \\
\text { szolgáltatás }\end{array}$} & Offline-termék &,$- 37^{*}$ & 009 \\
\hline & & E-termék &, 19 & ,209 \\
\hline & & E-szolgáltatás &,- 15 & 325 \\
\hline & \multirow{3}{*}{ E-termék } & Offline-termék &,$- 56^{*}$ &, 000 \\
\hline & & Offline-szolgáltatás &,- 19 & ,209 \\
\hline & & E-szolgáltatás &,$- 34^{*}$ & ,009 \\
\hline & \multirow{3}{*}{ E-szolgáltatás } & Offline-termék &,- 22 & 052 \\
\hline & & Offline-szolgáltatás &, 15 & ,325 \\
\hline & & E-termék & $34^{*}$ &, 009 \\
\hline
\end{tabular}

\section{9. táblázat: Az észlelt bizonság értékelése közti különbségek az e-kereskedelmi kategóriák esetében (1-7 skála)}

Forrás: saját eredmények alapján saját szerkesztés

Az elektronikus-szolgáltatásminőség utolsó dimenziója az ügyfélszolgálatra, vagyis a felmerülő kérdések, problémák kezelésére vonatkozik. Hasonlóan az előzőekhez a legmagasabb értékelést az offline-terméket vásárlók adták (átlagoff-term=6,36, szórásoff- 
term $=0,96$ ), míg leggyengébben az e-termékek vásárlása szerepelt (átlag e-term $=5,98$, szórás $\left._{\mathrm{e}-\mathrm{term}}=1,44\right)$. Ebben a kategóriában is jelentős azon válaszadók aránya, akik nem tudták az egyes állításokat értékelni: 173 válaszadó egyik állítást sem tudta értékelni, és 481 fő legalább egy állítást nem tudott minősíteni. A nem válaszolók aránya a négy szegmensben hasonlóan, 50\% körül alakult (20-21. táblázat). Ez azt jelenti, hogy a válaszadók közül sokan nem léptek kapcsolatba a vállalat ügyfélszolgálatával, tehát nem merült fel kérdésük, vagy problémájuk. A biztonságesetében követett eljáráshoz hasonlóan őket is megvizsgáljuk elkülönítve.

\begin{tabular}{|c|c|c|c|c|c|c|c|}
\hline \multicolumn{4}{|c|}{ Offline-termék } & \multicolumn{4}{|c|}{ Offline-szolg } \\
\hline Tulajdonság & Átlag & $\mathbf{N}(\mathbf{f o ̈})$ & Szórás & Tulajdonság & Átlag & $\mathbf{N}(\mathbf{f}$ "o) & Szórás \\
\hline $\mathrm{SC} 1$ & 6,29 & 253 & 1,23 & $\mathrm{SC} 1$ & 5,91 & 92 & 1,75 \\
\hline SC_ 2 & 6,39 & 282 & 1,20 & SC_2 & 6,22 & 108 & 1,31 \\
\hline SC 3 & 6,22 & 256 & 1,27 & SC 3 & 5,52 & 97 & 1,68 \\
\hline SC 4 & 6,27 & 225 & 1,20 & SC 4 & 5,78 & 88 & 1,66 \\
\hline SC 5 & 6,28 & 211 & 1,22 & SC 5 & 5,74 & 84 & 1,79 \\
\hline SC_6_OT & 6,01 & 366 & 1,61 & Átlagolt érték & 5,88 & 115 & 1,44 \\
\hline Átlagolt érték & 6,31 & 312 & 1,07 & & & & \\
\hline \multicolumn{4}{|c|}{ E-termék } & \multicolumn{4}{|c|}{ E-szolgáltatás } \\
\hline $\mathrm{SC}_{-} 1$ & 5,70 & 151 & 1,79 & $\mathrm{SC}_{-} 1$ & 6,03 & 193 & 1,37 \\
\hline SC_2 & 5,81 & 158 & 1,70 & SC_2 & 6,07 & 193 & 1,36 \\
\hline $\mathrm{SC}^{-3}$ & 5,62 & 138 & 1,80 & $\mathrm{SC} 3$ & 5,66 & 185 & 1,59 \\
\hline $\mathrm{SC} 4$ & 5,58 & 130 & 1,75 & SC_4 & 5,92 & 168 & 1,32 \\
\hline SC 5 & 5,57 & 129 & 1,84 & SC 5 & 6,01 & 165 & 1,33 \\
\hline Átlagolt érték & 5,74 & 176 & 1,64 & SC_6_ESZ & 5,83 & 263 & 1,69 \\
\hline & & & & Átlagolt érték & 6,04 & 224 & 1,17 \\
\hline
\end{tabular}

20. táblázat: Az ügyfélszolgálat értékelése (1-7 skála)

Forrás: saját eredmények alapján saját szerkesztés

\begin{tabular}{|c|c|c|c|c|}
\hline Függố változó & A csoport & B csoport & Kälönbség (A-B csop) & Sig. (F-próba) \\
\hline \multirow{12}{*}{$\begin{array}{l}\text { Ügyfélszolgálat } \\
\text { (átlagolt értékelés) }\end{array}$} & \multirow{3}{*}{$\begin{array}{l}\text { Offline- } \\
\text { termék }\end{array}$} & Offline-szolgáltatás &, $26^{*}$ &, 042 \\
\hline & & E-termék & $44^{*}$ &, 000 \\
\hline & & E-szolgáltatás &, 16 &, 137 \\
\hline & \multirow{3}{*}{$\begin{array}{l}\text { Offline- } \\
\text { szolgáltatás }\end{array}$} & Offline-termék &,$- 26^{*}$ & ,042 \\
\hline & & E-termék & , 17 & ,219 \\
\hline & & E-szolgáltatás &,- 11 &, 423 \\
\hline & \multirow{3}{*}{ E-termék } & Offline-termék &,$- 44^{*}$ &, 000 \\
\hline & & Offline-szolgáltatás &,- 17 &, 219 \\
\hline & & E-szolgáltatás &,$- 28^{*}$ &, 018 \\
\hline & \multirow{3}{*}{ E-szolgáltatás } & Offline-termék &,- 16 &, 137 \\
\hline & & Offline-szolgáltatás &, 11 &, 423 \\
\hline & & E-termék & $28^{*}$ &, 018 \\
\hline
\end{tabular}

\section{1. táblázat: Az ügyfélszolgálat értékelése közti különbségek az e-kereskedelmi} kategóriák esetében (1-7 skála)

Forrás: saját eredmények alapján saját szerkesztés 
Szignifikáns különbségek az értékelések között ismét megfigyelhetők: az offlineterméket vásárlók szignifikánsabb jobb átlagos értékelést adtak, mint az offlineszolgáltatást vagy e-terméket vásárlók (sigconservOT-OSz=0,042, sigconservOT$\mathrm{ET}=0,000$ ), valamint az e-szolgáltatást vásárlók értékelése is szignifikánsan magasabb, mint az e-terméket vásárlóké (sigconservEsz-ET=0,018).

$\mathrm{Az}$ átlagos teljes minőségértéket, vagyis a részleteiben vizsgált négy dimenzió átlagos értékelését megvizsgálva is az offline-termékeket vásárlók átlaga a legmagasabb, míg az e-termékeket vásárlóké a legalacsonyabb (átlag ${ }_{\mathrm{off}-\text { term }}=6,30$, szórás off-term $=0,84$, átlageterm $=5,53$, szóráse-term=1,30). A minőségészlelés tekintetében szignifikáns különbség mindössze az offline-termékeket és e-szolgáltatásokat vásárlók között nem áll fenn, minden egyéb átlag szignifikánsan eltér ( $22-23$. táblázat).

\begin{tabular}{|l|c|c|c|}
\hline & Átlag & $\mathbf{N}$ (fó) & Szórás \\
\hline Offline-termék & 6,30 & 366 & 0,84 \\
\hline Offline-szolgáltatás & 5,95 & 134 & 0,97 \\
\hline E-termék & 5,59 & 237 & 1,30 \\
\hline E-szolgáltatás & 6,24 & 263 & 0,96 \\
\hline
\end{tabular}

\section{2. táblázat: Az szummázott minőségészlelés értékelése (1-7 skála)}

Forrás: saját eredmények alapján saját szerkesztés

\begin{tabular}{|c|c|c|c|c|}
\hline Függó változó & A csoport & B csoport & Különbség (I-J) & Sig. $(F-p r o ́ b a)$ \\
\hline \multirow{12}{*}{$\begin{array}{l}\text { Szummázott } \\
\text { minőségészlelés } \\
\text { (átlag) }\end{array}$} & \multirow{3}{*}{$\begin{array}{l}\text { Offline- } \\
\text { termék }\end{array}$} & Offline-szolgáltatás &, $3089^{*}$ & ,006 \\
\hline & & E-termék & ,7660* &, 000 \\
\hline & & E-szolgáltatás & 0,05 &, 569 \\
\hline & \multirow{3}{*}{$\begin{array}{l}\text { Offline- } \\
\text { szolgáltatás }\end{array}$} & Offline-termék &,$- 3089^{*}$ & 006 \\
\hline & & E-termék &, $4570^{*}$ &, 000 \\
\hline & & E-szolgáltatás &,$- 2574^{*}$ &, 029 \\
\hline & \multirow{3}{*}{ E-termék } & Offline-termék &,$- 7660^{*}$ &, 000 \\
\hline & & Offline-szolgáltatás &,$- 4570^{*}$ &, 000 \\
\hline & & E-szolgáltatás &,$- 7144^{*}$ &, 000 \\
\hline & \multirow{3}{*}{$\begin{array}{l}\text { E- } \\
\text { szolgáltatás }\end{array}$} & Offline-termék & $-0,05$ &, 569 \\
\hline & & Offline-szolgáltatás & $2574^{*}$ & 029 \\
\hline & & E-termék &, $7144^{*}$ &, 000 \\
\hline
\end{tabular}

\section{3. táblázat: A szummázott minőségészlelés közti különbségek az e- kereskedelmi kategóriák esetében (1-7 skála)}

Forrás: saját eredmények alapján saját szerkesztés

Az eredmények alapján láthatjuk, hogy a legjobb értékeléseket az offline-termékek, valamint az e-szolgáltatások vásárlására használt webshopok kapták, míg leggyengébben az e-termékeket értékesítő webshopok szerepeltek. Ez alapján megállapítható, hogy ebben az e-kereskedelmi szegmensben még jelentős fejlesztéseket kell az üzemeltetőknek véghezvinni. 


\subsubsection{Az elégedettség és következményei}

A szignifikánsan eltérő minőségészlelés ellenére az elégedettségi szintek hasonlóan alakultak, és a négy szegmens esetében nem figyelhető meg szignifikáns eltérés. Ezzel ellentétben az elégedettség és minőség következményeiben már jelentős eltérések figyelhetők meg. Minden esetben az offline-terméket vásárlók átlagos hajlandósága a

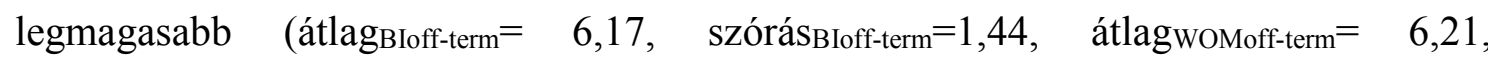
szórás ${ }_{W O M o f f-t e r m}=1,20$, átlag ${ }_{\mathrm{E}-\text { WOMoff-term }}=5,72$, szórás E-WOMoff-term $\left.=1,84\right)$, és ezen átlagok az újravásárlási szándék kivételével szignifikánsan eltérnek minden egyéb szegmens átlagaitól. Az észlelt minőség áltagos szintjével ellentétben az e-termékeket vásárlók hajlandósága nem a leggyengébbnek számít, hanem az offline-termékeket vásárlók után a második legerősebb átlagokat mutatja, bár az egyéb szegmensek értékelésétől nem különbözik szignifikánsan (24-25. táblázat).

\begin{tabular}{|l|c|c|c|c|c|c|}
\hline & \multicolumn{3}{|c|}{ Offline-termék } & \multicolumn{3}{c|}{ Offline-szolgáltatás } \\
\hline & $\mathbf{A}$ tlag & $\mathbf{N}$ & Szórás & Átlag & $\mathbf{N}$ & Szórás \\
\hline SAT1 & 6,43 & 366 & 1,17 & 6,30 & 134 & 1,14 \\
\hline SAT2 & 6,44 & 366 & 1,17 & 6,34 & 134 & 1,02 \\
\hline SAT3 & 6,44 & 366 & 1,15 & 6,31 & 134 & 1,16 \\
\hline SAT_avg & $\mathbf{6 , 4 4}$ & $\mathbf{3 6 6}$ & $\mathbf{1 , 1 2}$ & $\mathbf{6 , 3 2}$ & $\mathbf{1 3 4}$ & $\mathbf{1 , 0 7}$ \\
\hline BI1 & 6,17 & 366 & 1,44 & 5,95 & 134 & 1,53 \\
\hline WOM1 & 6,41 & 366 & 1,17 & 6,07 & 134 & 1,34 \\
\hline WOM2 & 6,40 & 366 & 1,22 & 6,08 & 134 & 1,34 \\
\hline WOM3 & 6,34 & 366 & 1,27 & 5,99 & 134 & 1,42 \\
\hline WOM_avg & $\mathbf{6 , 2 1}$ & $\mathbf{3 6 6}$ & $\mathbf{1 , 2 0}$ & $\mathbf{5 , 8 4}$ & $\mathbf{1 3 4}$ & $\mathbf{1 , 3 0}$ \\
\hline EWOM1 & 5,72 & 366 & 1,84 & 5,10 & 134 & 1,92 \\
\hline & & $\mathbf{E}-t e r m e ́ k$ & & & $\mathbf{E}-$-szolgáltatás \\
\hline SAT1 & 6,40 & 237 & 1,22 & 6,28 & 263 & 1,19 \\
\hline SAT2 & 6,36 & 237 & 1,26 & 6,40 & 263 & 1,04 \\
\hline SAT3 & 6,35 & 237 & 1,26 & 6,37 & 263 & 1,09 \\
\hline SAT_avg & $\mathbf{6 , 3 7}$ & $\mathbf{2 3 7}$ & $\mathbf{1 , 1 6}$ & $\mathbf{6 , 3 5}$ & $\mathbf{2 6 3}$ & $\mathbf{1 , 0 5}$ \\
\hline BI1 & 5,99 & 237 & 1,53 & 5,88 & 263 & 1,52 \\
\hline WOM1 & 6,27 & 237 & 1,28 & 6,25 & 263 & 1,21 \\
\hline WOM2 & 6,19 & 237 & 1,34 & 6,05 & 263 & 1,40 \\
\hline WOM3 & 6,17 & 237 & 1,40 & 6,05 & 263 & 1,43 \\
\hline WOM_avg & $\mathbf{5 , 9 9}$ & $\mathbf{2 3 7}$ & $\mathbf{1 , 2 8}$ & $\mathbf{5 , 9 0}$ & $\mathbf{2 6 3}$ & $\mathbf{1 , 2 7}$ \\
\hline EWOM1 & 5,35 & 237 & 2,05 & 5,25 & 263 & 1,97 \\
\hline
\end{tabular}

24. táblázat: Az elégedettség, hagyományos és e-továbbajánlási hajlandóság, valamint az újravásárlási szándék értékelése (1-7 skála)

Forrás: saját eredmények alapján saját szerkesztés

Ezek alapján megállapíthatjuk, hogy az eltérő minőségészlelés ellenére az újravásárlási és továbbajánlási hajlandóság az offline-termékek kivételével nagyon hasonlóan alakul, tehát az észlelt minőség hatása ezekben az esetekben gyengébbnek tekinthető. 


\begin{tabular}{|c|c|c|c|c|}
\hline Függó változó & A csoport & B csoport & Különbség (I-J) & Sig. $(F-p r o ́ b a)$ \\
\hline \multirow{12}{*}{$\begin{array}{l}\text { Elégedettség } \\
\text { (átlagolt értékelés) }\end{array}$} & \multirow{3}{*}{$\begin{array}{l}\text { Offline- } \\
\text { termék }\end{array}$} & Offline-szolgáltatás & 0,07 &, 558 \\
\hline & & E-termék & 0,12 & 284 \\
\hline & & E-szolgáltatás & 0,00 & 964 \\
\hline & \multirow{3}{*}{$\begin{array}{l}\text { Offline- } \\
\text { szolgáltatás }\end{array}$} & Offline-termék & $-0,07$ &, 558 \\
\hline & & E-termék & 0,04 &, 758 \\
\hline & & E-szolgáltatás & $-0,07$ &, 601 \\
\hline & \multirow{3}{*}{ E-termék } & Offline-termék & $-0,12$ & 284 \\
\hline & & Offline-szolgáltatás & $-0,04$ & ,758 \\
\hline & & E-szolgáltatás & $-0,11$ & ,335 \\
\hline & \multirow{3}{*}{ E-szolgáltatás } & Offline-termék & 0,00 & 964 \\
\hline & & Offline-szolgáltatás & 0,07 & 601 \\
\hline & & E-termék & 0,11 & ,335 \\
\hline \multirow{12}{*}{$\begin{array}{l}\text { Hagyományos } \\
\text { továbbjánlás } \\
\text { hajlandóság } \\
\text { (átlagolt értékelés) }\end{array}$} & \multirow{3}{*}{$\begin{array}{l}\text { Offline- } \\
\text { termék }\end{array}$} & Offline-szolgáltatás &, $33^{*}$ &, 020 \\
\hline & & E-termék &, $29^{*}$ &, 018 \\
\hline & & E-szolgáltatás & $23^{*}$ & 041 \\
\hline & \multirow{3}{*}{$\begin{array}{l}\text { Offline- } \\
\text { szolgáltatás }\end{array}$} & Offline-termék &,$- 33^{*}$ &, 020 \\
\hline & & E-termék & $-0,04$ & ,794 \\
\hline & & E-szolgáltatás & $-0,10$ & 518 \\
\hline & \multirow{3}{*}{ E-termék } & Offline-termék &,$- 29^{*}$ & 018 \\
\hline & & Offline-szolgáltatás & 0,04 & ,794 \\
\hline & & E-szolgáltatás & $-0,06$ &, 667 \\
\hline & \multirow{3}{*}{ E-szolgáltatás } & Offline-termék &,$- 23^{*}$ & 041 \\
\hline & & Offline-szolgáltatás & 0,10 &, 518 \\
\hline & & E-termék & 0,06 & 667 \\
\hline \multirow{12}{*}{$\begin{array}{l}\text { E-továbbajánlási } \\
\text { hajlandóság }\end{array}$} & \multirow{3}{*}{$\begin{array}{l}\text { Offline- } \\
\text { termék }\end{array}$} & Offline-szolgáltatás &, $61^{*}$ &, 004 \\
\hline & & E-termék &, $52^{*}$ &, 005 \\
\hline & & E-szolgáltatás &, $36^{*}$ &, 036 \\
\hline & \multirow{3}{*}{$\begin{array}{l}\text { Offline- } \\
\text { szolgáltatás }\end{array}$} & Offline-termék &,$- 61^{*}$ & 004 \\
\hline & & E-termék & $-0,09$ &, 694 \\
\hline & & E-szolgáltatás & $-0,25$ &, 265 \\
\hline & \multirow{3}{*}{ E-termék } & Offline-termék &,$- 52^{*}$ &, 005 \\
\hline & & Offline-szolgáltatás & 0,09 & ,694 \\
\hline & & E-szolgáltatás & $-0,16$ & 420 \\
\hline & \multirow{3}{*}{ E-szolgáltatás } & Offline-termék &,$- 36^{*}$ & 036 \\
\hline & & \begin{tabular}{|l|} 
Offline-szolgáltatás \\
\end{tabular} & 0,25 & 265 \\
\hline & & E-termék & 0,16 & 420 \\
\hline \multirow{12}{*}{$\begin{array}{l}\text { Újravásárlási } \\
\text { szándék }\end{array}$} & \multirow{3}{*}{$\begin{array}{l}\text { Offline- } \\
\text { termék }\end{array}$} & Offline-szolgáltatás & 0,19 & 240 \\
\hline & & E-termék & 0,15 & 295 \\
\hline & & E-szolgáltatás & 0,19 &, 150 \\
\hline & \multirow{3}{*}{$\begin{array}{l}\text { Offline- } \\
\text { szolgáltatás }\end{array}$} & Offline-termék & $-0,19$ & 240 \\
\hline & & E-termék & $-0,05$ & 801 \\
\hline & & E-szolgáltatás & 0,00 & 989 \\
\hline & \multirow{3}{*}{ E-termék } & Offline-termék & $-0,15$ & 295 \\
\hline & & Offline-szolgáltatás & 0,05 & 801 \\
\hline & & E-szolgáltatás & 0,04 &, 776 \\
\hline & \multirow{3}{*}{ E-szolgáltatás } & Offline-termék & $-0,19$ &, 150 \\
\hline & & Offline-szolgáltatás & 0,00 & ,989 \\
\hline & & E-termék & $-0,04$ & ,776 \\
\hline
\end{tabular}

25. táblázat: A vizsgált e-kereskedelmi kategóriák közti különbség az elégedettség, hagyományos és e-továbbajánlási hajlandóság, valamint az újravásárlási szándék értékelése esetében (1-7 skála)

Forrás: saját eredmények alapján saját szerkesztés 


\subsubsection{A nem válaszolók}

A strukturális modellezés során a hiányzó értékek kezelése kulcskérdés, mivel a hiányzó értékek figyelmen kívül hagyása számos torzítást okozhat modellünkben (Weiber Mühlhaus, 2010). Mivel a hiányzó adatok lehetnek nem random, teljes mértékben random, illetve random hiányzó adatok, ezért kezelésük előtt szeretnénk őket részleteiben megismerni. Mint ahogy az 4.1.3 fejezetben is megjegyeztük, a kutatásunk során a biztonsághoz és az ügyfélszolgálathoz kapcsolódó dimenziókat nem tudta minden válaszadónk értékelni, mert nem állt rendelkezésére információ az adott tényezőről. Ebből adódóan tehát megfigyelhető összefüggés a hiányzó adatok esetében - mely a tapasztalat hiányával írható le -, ezért nem random hiányzó adatokról beszélünk (Neumann-Bódi, 2012).

Azzal a ténnyel, hogy nem minden online vásárlónak van tapasztalata az ügyfélszolgálattal már Parasuraman és társai (2005) is foglalkoztak, ezért az általuk megalkotott minőségmérő skálában ezeket a dimenziókat teljesen elkülönítve, az észlelt minőség egy másodlagos dimenziójaként kezelik, és eredményeiket elkülönülten is megvizsgálják (a részleteket lásd a 2.4.9. fejezetben).

Jelen kutatásunk során összesen 623 olyan egyén volt, aki a biztonsághoz és/vagy ügyfélszolgálathoz kapcsolódó manifeszt változók közül legalább egyet nem tudott értékelni, tehát legalább egy hiányzó értékkel rendelkezik. Összesen 274 fö az, aki mindkét dimenzióból legalább egy tényezőt nem tudott értékelni, 142 fő az, aki a biztonsághoz kapcsolódóan, és 207 fö az, aki csak az ügyfélszolgálat esetében nem tudott minden esetben nyilatkozni (26. táblázat).

\begin{tabular}{|c|c|c|c|c|c|}
\hline & & & \multicolumn{2}{|c|}{ Tapasztalat a biztonsággal } & \\
\hline & & & $\begin{array}{l}\text { Mindent } \\
\text { tudott } \\
\text { értékelni }\end{array}$ & $\begin{array}{l}\text { Legalább egy } \\
\text { dolgot nem } \\
\text { tudott értékelni }\end{array}$ & \\
\hline \multirow{3}{*}{$\begin{array}{l}\text { Legalább egy dolgot } \\
\text { nem tudott értékelni a } \\
\text { biztonság és az } \\
\text { ügyfélszolgálat } \\
\text { dimenziói közül }\end{array}$} & \multirow[t]{2}{*}{$\begin{array}{l}\text { Tapasztalat az } \\
\text { ügyfélszolgálattal }\end{array}$} & $\begin{array}{l}\text { Mindent tudott } \\
\text { értékelni }\end{array}$ & 377 & 142 & 142 \\
\hline & & $\begin{array}{l}\text { Legalább egy dolgot } \\
\text { nem tudott értékelni }\end{array}$ & 207 & 274 & 481 \\
\hline & \multicolumn{2}{|l|}{ Teljes } & 207 & 416 & 1000 \\
\hline
\end{tabular}

26. táblázat: A nem válaszolók megoszlása a mintában

Forrás: saját eredmények alapján saját szerkesztés

Mint ahogy az 27. táblázat is mutatja, a legtöbben a felmerülő kérdések és a problémák kezelésével kapcsolatos állításokra nem válaszoltak (411fö, 389 fö, 324 fö), míg a 
biztonság dimenziójánál a legtöbben a bankkártya biztonságának garantálásáról (300fó), illetve a személyes adatok felhasználásáról (200fő) nem tudtak nyilatkozni.

\begin{tabular}{|l|l|c|c|c|c|}
\hline \multicolumn{1}{|c|}{ Manifeszt változó } & $\begin{array}{c}\text { Nem } \\
\text { válaszolók } \\
\text { száma }\end{array}$ & $\begin{array}{c}\text { Egyikkel sem } \\
\text { volt } \\
\text { tapasztalata }\end{array}$ & $\begin{array}{c}\text { A biztonsággal } \\
\text { kapcsolatban } \\
\text { nem volt } \\
\text { tapasztalata }\end{array}$ & $\begin{array}{c}\text { Az ügyfélszolgálattal } \\
\text { kapcsolatban nem } \\
\text { volt tapasztalata }\end{array}$ \\
\hline SC_5 & $\begin{array}{l}\text { A vállalat szívesen segített a } \\
\text { felmerülö problémák } \\
\text { kezelésében. }\end{array}$ & 411 & 234 & 0 & 177 \\
\hline SC_4 & $\begin{array}{l}\text { A kérdése(i)mre adott válaszok } \\
\text { segítettek/hasznosak voltak. }\end{array}$ & 389 & 223 & 0 & 166 \\
\hline SC_3 & $\begin{array}{l}\text { A vállalattal folytatott } \\
\text { kommunikáció személyes } \\
\text { hangvételü volt. }\end{array}$ & 324 & 176 & 0 & 148 \\
\hline SC_1 & $\begin{array}{l}\text { Az ügyfélszolgáltat elérése } \\
\text { egyszerü volt. }\end{array}$ & 311 & 194 & 0 & 117 \\
\hline SEC_2 & $\begin{array}{l}\text { A bankkártyám/hitelkártyám } \\
\text { biztonsága garantált volt. }\end{array}$ & 300 & 199 & 101 & 112 \\
\hline SC_2 & $\begin{array}{l}\text { A vállalat gyorsan válaszolt az } \\
\text { e-mailemre. }\end{array}$ & 259 & 147 & 0 & 0 \\
\hline SEC_4 & $\begin{array}{l}\text { A személyes adataimat } \\
\text { bizalmasan kezelték. }\end{array}$ & 200 & 156 & 44 & 0 \\
\hline SEC_1 & $\begin{array}{l}\text { A biztonsághoz kapcsolódó } \\
\text { információk egyértelmúen } \\
\text { voltak elmagyarázva. }\end{array}$ & 189 & 141 & 48 & 0 \\
\hline SEC_3 & $\begin{array}{l}\text { A személyes adatok } \\
\text { felhasználását részletesen } \\
\text { leírták. }\end{array}$ & 145 & 119 & 26 & 0 \\
\hline
\end{tabular}

\section{7. táblázat: A nem válaszolók megoszlása a mintában a konkrét kérdések/változók esetében}

Forrás: saját eredmények alapján saját szerkesztés

A 623 hiányos kitöltésből a legtöbb nem válaszoló az offline-termékek vásárlói köréből származott (68,3\%), legkisebb arányban pedig az offline-szolgáltatások $(51,5 \%)$ esetében találkozunk ilyen egyénekkel. A hiányos tapasztalatokat részleteiben megvizsgálva megállapítható, hogy a biztonsággal, illetve a mindkét dimenzióval kapcsolatban hiányos információkkal rendelkezők többsége offline-termék vásárolt (51\% és 45\%), míg az ügyfélszolgálattal kapcsolatos hiányos tapasztalatok esetében közel azonos szinten képviseltetik magukat az e-terméket, e-szolgáltatást és offline-terméket vásárlók (30\%, $29 \%, 25 \%)$ (28. táblázat).

Az eredmények alapján megállapítható, hogy az offline-terméket az interneten vásárolók esetében a biztonsághoz kapcsolódó tényezők kevésbé „fontosak”, mivel többségük az ehhez tartozó tényezők közül nem tudta mindet érdemben értékelni. Az ügyfélszolgálat teljes értékelése - vagyis a kommunikáció módja, hangvétele - általánosságban a vásárlók fele esetében releváns dimenzió, tehát megközelítőleg a vásárlók felének (337 fö + 142 fö) volt valamilyen jellegü kapcsolata az ügyfélszolgálattal. 


\begin{tabular}{|l|c|c|c|c|c|c|}
\hline & $\begin{array}{c}\text { Egyikkel sem } \\
\text { volt } \\
\text { tapasztalata }\end{array}$ & $\begin{array}{c}\text { A biztonsággal } \\
\text { kapcsolatban } \\
\text { nem volt } \\
\text { tapasztalata }\end{array}$ & $\begin{array}{c}\text { Az ügyfélszolgálattal } \\
\text { kapcsolatban nem volt } \\
\text { tapasztalata }\end{array}$ & $\begin{array}{c}\text { Mindennel volt } \\
\text { tapasztalata }\end{array}$ & Teljes & $N$ \\
\hline Offline-termék & $45 \%$ & $51 \%$ & $26 \%$ & $31 \%$ & $37 \%$ & 366 \\
\hline Offline-szolgáltatás & $11 \%$ & $6 \%$ & $14 \%$ & $17 \%$ & $13 \%$ & 134 \\
\hline E-termék & $21 \%$ & $13 \%$ & $30 \%$ & $26 \%$ & $24 \%$ & 237 \\
\hline E-szolgáltatás & $22 \%$ & $30 \%$ & $29 \%$ & $26 \%$ & $26 \%$ & 263 \\
\hline Teljes & $100 \%$ & $100 \%$ & $100 \%$ & $100 \%$ & \multirow{2}{*}{$100 \%$} & \multirow{2}{*}{1000} \\
\hline$N$ & 274 & 142 & 207 & 377 & &
\end{tabular}

28. táblázat: A nem válaszolók megoszlása a mintában a vizsgált ekereskedelmi szegmensek esetében

Forrás: saját eredmények alapján saját szerkesztés

Amennyiben összevetjük a legalább egy hiányzó értékkel rendelkezők és a mindenre válaszolók átlagolt értékeléseit a minőségészlelés, az elégedettség és annak következményei esetében, szignifikáns eltéréseket figyelhetünk meg (29. táblázat). Az online ajánlási hajlandóság kivételével minden esetben a teljes tapasztalattal rendelkezők átlagolt értékelése a legalacsonyabb, tehát azok véleménye a „leggyengébb”, akik teljes képpel rendelkeznek az e-szolgáltatásminőség minden egyes dimenziójáról, vagyis információval rendelkeznek a biztonsági feltétekről, illetve az ügyfélszolgálattal is kapcsolatba kerültek. A legmagasabb értékelés azon válaszadókhoz köthető, akiknek nem volt kapcsolata az ügyfélszolgálattal, tehát semmilyen kérdés vagy probléma nem merült fel a vásárlásuk során, úgymond gördülékenyen zajlott a vásárlásuk, és a biztonsághoz tartozó tételekről teljes információval rendelkeznek.

Eredményeink alapján már az átlagolt értékelésekben releváns különbségek figyelhetőek meg a teljes, illetve a hiányos tapasztalattal rendelkezők esetében, ezért a felvázolt struktúra, és a feltételezett különbségek értékelése során célszerünek látjuk a négy csoportot külön megvizsgálni, és a hiányzó adatok pótlásából származó esetleges torzításokat ezzel kikerülni. Erre azért is szükség van, mert a hiányzó értékek jelen esetben nem random mutatkoznak, hanem a megkérdezettek tapasztalataira és a rendelkezésünkre álló információkra, illetve percepciókra vezethetőek vissza.

\subsubsection{A strukturális modell értékelése}

A feltételezett kapcsolatrendszer elemzésére a strukturális modellezés módszerét választottuk, mely képes egyszerre több látens változó összefüggéseit vizsgálni. A kovariancia és variancia alapú modellezések közül végül a variancia alapút választottuk, mert ennek a módszernek nem feltétele a vizsgálatba bevont változók normális eloszlása, 
valamint a modell komplexitásával a PLS-SEM esetében nem gyengül az egyes mutatók értéke (Chin - Newsted, 1999).

\begin{tabular}{|c|c|c|c|c|c|c|c|}
\hline & & $\begin{array}{l}\text { Egyikkel } \\
\text { sem volt } \\
\text { tapasztalata }\end{array}$ & $\begin{array}{c}\text { A } \\
\text { biztonsággal } \\
\text { kapcsolatban } \\
\text { nem volt } \\
\text { tapasztalata }\end{array}$ & $\begin{array}{c}\mathrm{Az} \\
\text { ügyfélszolgálattal } \\
\text { kapcsolatban nem } \\
\text { volt tapasztalata }\end{array}$ & $\begin{array}{l}\text { Mindennel } \\
\text { volt } \\
\text { tapasztalata }\end{array}$ & Teljes & $\begin{array}{l}\text { Szig } \\
\text { F- } \\
\text { próba }\end{array}$ \\
\hline \multirow{3}{*}{$\begin{array}{l}\text { Konkrét webshop- } \\
\text { minőség } \\
\text { (átlagolt értékelés) }\end{array}$} & $\mathrm{N}$ (fö) & 274 & 142 & 207 & 377 & 1000 & \multirow{3}{*}{0,001} \\
\hline & Átlag & 5,73 & 5,97 & 5,92 & 5,51 & 5,72 & \\
\hline & Szórás & 1,6 & 1,35 & 1,32 & 1,49 & 1,48 & \\
\hline \multirow{3}{*}{$\begin{array}{c}\text { Vásárlás } \\
\text { lebonyolításának } \\
\text { minősége } \\
\text { (átlagolt értékelés) }\end{array}$} & $\mathrm{N}$ (fö) & 274 & 142 & 207 & 377 & 1000 & \multirow{3}{*}{0,000} \\
\hline & Átlag & 6,48 & 6,4 & 6,56 & 5,97 & 6,29 & \\
\hline & Szórás & 0,97 & 0,98 & 0,73 & 1,29 & 1,09 & \\
\hline \multirow{3}{*}{$\begin{array}{l}\text { Ügyfélszolgálat } \\
\text { (átlagolt értékelés) }\end{array}$} & $\mathrm{N}$ (fö) & \multirow{3}{*}{$\begin{array}{l}\text { Nem } \\
\text { releváns }\end{array}$} & 142 & \multirow{3}{*}{ Nem releváns } & 377 & 827 & \multirow{3}{*}{0,000} \\
\hline & Átlag & & 6,21 & & 5,79 & 6,06 & \\
\hline & Szórás & & 1,25 & & 1,39 & 1,31 & \\
\hline \multirow{3}{*}{$\begin{array}{c}\text { Biztonság } \\
\text { (átlagolt értékelés) }\end{array}$} & $\mathrm{N}$ (fo) & \multirow{3}{*}{$\begin{array}{l}\text { Nem } \\
\text { releváns }\end{array}$} & \multirow{3}{*}{$\begin{array}{l}\text { Nem } \\
\text { releváns }\end{array}$} & 207 & 377 & 923 & \multirow{3}{*}{0,000} \\
\hline & Átlag & & & 6,41 & 5,97 & 6,19 & \\
\hline & Szórás & & & 0,84 & 1,27 & 1,17 & \\
\hline \multirow{3}{*}{$\begin{array}{l}\text { Észlelt elektronikus } \\
\text { szolgáltatásminőség } \\
\text { (átlagolt értékelés) }\end{array}$} & $\mathrm{N}$ (fó) & 274 & 142 & 207 & 377 & 1000 & \multirow{3}{*}{0,000} \\
\hline & Átlag & 6,18 & 6,2 & 6,32 & 5,81 & 6,07 & \\
\hline & Szórás & 1,02 & 0,94 & 0,74 & 1,2 & 1,05 & \\
\hline \multirow{3}{*}{$\begin{array}{c}\text { Elégedettség } \\
\text { (átlagolt értékelés) }\end{array}$} & \begin{tabular}{|l|}
$\mathrm{N}$ (fö) \\
\end{tabular} & 274 & 142 & 207 & 377 & 1000 & \multirow{3}{*}{0,000} \\
\hline & Átlag & 6,54 & 6,56 & 6,68 & 6,03 & 6,38 & \\
\hline & \begin{tabular}{|l} 
Szórás \\
\end{tabular} & 1,01 & 0,9 & 0,69 & 1,32 & 1,11 & \\
\hline \multirow{3}{*}{$\begin{array}{c}\text { Ajánlási } \\
\text { hajlandóság } \\
\text { (átlagolt értékelés) }\end{array}$} & N (fö) & 274 & 142 & 207 & 377 & 1000 & \multirow{3}{*}{0,000} \\
\hline & Átlag & 6,06 & 6,2 & 6,3 & 5,78 & 6,03 & \\
\hline & Szórás & 1,21 & 1,19 & 0,91 & 1,42 & 1,26 & \\
\hline \multirow{3}{*}{$\begin{array}{l}\text { Online ajánlási } \\
\text { hajlandóság }\end{array}$} & N (fö) & 274 & 142 & 207 & 377 & 1000 & \multirow{3}{*}{0,013} \\
\hline & Átlag & 5,19 & 5,71 & 5,67 & 5,35 & 5,43 & \\
\hline & Szórás & 2,13 & 1,88 & 1,8 & 1,89 & 1,95 & \\
\hline \multirow{5}{*}{$\begin{array}{l}\text { Újravásárlási } \\
\text { szándék }\end{array}$} & N (fó) & 274 & 142 & 207 & 377 & 1000 & \multirow{5}{*}{0,001} \\
\hline & Átlag & 6,07 & 6,04 & 6,33 & 5,82 & 6,02 & \\
\hline & Szórás & 1,54 & 1,61 & 1,24 & 1,53 & 1,50 & \\
\hline & \begin{tabular}{|l|} 
Átlag \\
\end{tabular} & 6,53 & 6,56 & 6,66 & 6,22 & 6,44 & \\
\hline & Szórás & 0,78 & 0,74 & 0,57 & 1,07 & 0,88 & \\
\hline
\end{tabular}

\section{9. táblázat: A nem válaszolók csoportjai és a hiánytalan kitöltők közti különbségek a vásárlás értékeléséhez köthető dimenziók esetében}

\section{Forrás: saját eredmények alapján saját szerkesztés}

A strukturális modellezéskor mindig két elmélet tesztelésére kerül sor: első körben a mérési elméletet teszteljük, vagyis hogy az alkalmazott változócsoportok (skálák) megfelelőek-e, és ezután térhetünk ki a tényleges struktúra, vagyis a feltételezett kapcsolatok tesztelésére (Hensler et al. 2009). 


\subsubsection{A mérési modell, vagyis az elmélet tesztelése}

A mérési modell tesztelésekor a látens változók érvényességét és megbízhatóságát teszteljük, vagyis ellenőrizzük az indikátor megbízhatóságát, úgymint a belső megbízhatóságot (internal consistency reliability), a hasonlósági érvényességet (convergence validity), valamint a különbözöségi érvényességet (discriminant validity). Kutatásunk során reflektív mérési modellekkel dolgozunk.

\begin{tabular}{|c|c|c|c|c|}
\hline & Offline-termék & Offline-szolgáltatás & E-termék & E-szolgáltatás \\
\hline & \multicolumn{4}{|c|}{ Átlagos magyarázott variancia } \\
\hline Konkrét webshop minőség & 0,801 & 0,803 & 0,682 & 0,792 \\
\hline Vásárlás lebonyolítása & 0,841 & 0,850 & 0,869 & 0,789 \\
\hline Biztonság & 0,817 & 0,860 & 0,891 & 0,802 \\
\hline Ügyfélszolgálat & 0,798 & 0,752 & 0,884 & 0,742 \\
\hline Elégedettség & 0,967 & 0,974 & 0,921 & 0,932 \\
\hline tr.-WOM & 0,954 & 0,947 & 0,959 & 0,924 \\
\hline E-WOM & 1,000 & 1,000 & 1,000 & 1,000 \\
\hline Újravásárlási szándék & 1,000 & 1,000 & 1,000 & 1,000 \\
\hline \multirow[t]{2}{*}{ Elvárt érték } & \multicolumn{4}{|c|}{ AVE $>0,5$, Fornell - Larcker, 1981) } \\
\hline & \multicolumn{4}{|c|}{ Belső megbízhatóság - Dillon-Goldstein's Rho } \\
\hline Konkrét webshop minőség & 0,942 & 0,942 & 0,893 & 0,938 \\
\hline Vásárlás lebonyolítása & 0,963 & 0,966 & 0,971 & 0,949 \\
\hline Biztonság & 0,947 & 0,961 & 0,970 & 0,942 \\
\hline Ügyfélszolgálat & 0,959 & 0,938 & 0,974 & 0,945 \\
\hline Elégedettség & 0,989 & 0,991 & 0,972 & 0,976 \\
\hline tr.-WOM & 0,984 & 0,982 & 0,986 & 0,973 \\
\hline E-WOM & 1,000 & 1,000 & 1,000 & 1,000 \\
\hline Újravásárlási szándék & 1,000 & 1,000 & 1,000 & 1,000 \\
\hline \multirow[t]{2}{*}{ Elvárt érték } & \multicolumn{4}{|c|}{$D-G-R>0,7$ (Vandenbosch 1996) } \\
\hline & \multicolumn{4}{|c|}{ Belső megbízhatóság - Cronbach-alfa } \\
\hline Konkrét webshop minőség & 0,918 & \begin{tabular}{|c|}
0,918 \\
\end{tabular} & 0,833 & 0,912 \\
\hline Vásárlás lebonyolítása & 0,952 & 0,956 & 0,962 & 0,933 \\
\hline Biztonság & 0,925 & 0,945 & 0,959 & 0,917 \\
\hline Ügyfélszolgálat & 0,948 & 0,917 & 0,967 & 0,930 \\
\hline Elégedettség & 0,983 & 0,987 & 0,957 & 0,964 \\
\hline tr.-WOM & 0,976 & 0,972 & 0,979 & 0,959 \\
\hline E-WOM & 1,000 & 1,000 & 1,000 & 1,000 \\
\hline Újravásárlási szándék & 1,000 & 1,000 & 1,000 & 1,000 \\
\hline Elvárt érték & \multicolumn{4}{|c|}{$\alpha>0,7$ (Nunnaly - Bernstein 1994) } \\
\hline
\end{tabular}

\section{0. táblázat: A mérési modell tesztelésének eredménye (belső megbízhatóság, hasonlósági érvényesség)}

Forrás: saját eredmények alapján saját szerkesztés

A belső megbízhatóságot a Cronbach-alfa, és/vagy az indikátorokhoz kapcsolódó megbízhatósági mutató elemzésével mérhetjük (composite reliability). A Cronbach-alfa értékek elemzése mellett azért tartjuk fontosnak egy másik mutató vizsgálatát is, mert a szakirodalomban több kritika is megfogalmazódott már a Cronbach-alfával szemben. Ezen kritikák szerint az együttható értéke a skálához tartozó manifeszt változók számával növekszik, így ajánlott az egy indikátorhoz kapcsolódó megbízhatósági mutató 
alkalmazása is (Fornell - Larcker, 1981; Hair et al., 2010). A PLS-SEM esetében ezt a fajta belső megbízhatóságot a Dillon-Goldstein-féle Rho mutatóval mérhetjük. Mindkét mutatóval szemben az az elvárásunk, hogy az egyes látensekhez tartozó értékek legalább 0,7 értéket vegyenek fel (Vandenbosch, 1996; Nunnaly - Bernstein, 1994).

Mivel Francis és White az általuk elkülönített négy e-kereskedelmi szegmensben a szolgáltatásminőség mérésére különböző manifeszt változókat használtak, ezért kutatásunk első részében négy különböző modell esetében kell a fentebb megnevezett mutatókat megvizsgálni. Az eredmények alapján (30. táblázat) megállapítható, hogy a belső megbízhatóság és a hasonlósági érvényesség mutatói mind a négy modell esetében megfelelőek, azonban az elektronikus szolgáltatások vásárlása esetében a különbözőségi érvényesség feltétel nem teljesül: a korrelációs négyzetösszeg magasabb az átlagos magyarázott varianciánál a konkrét webshopminőség és a vásárlás lebonyolításának minősége esetében (5. számú melléklet). Azonban mivel mindkét változó a minőségészleléshez kapcsolódik, ettől a feltételtől jelen esetben el tudunk tekinteni. ${ }^{9}$

Az érvényességi és megbízhatósági mutatók mellett az objektivitást is meg kell vizsgálnunk a részletes elemzések előtt. Ennek során célunk, hogy megállapítsuk az eredményeink függetlenségét a kutató személyétől (Malhotra - Simon, 2008). Mivel az adatfelvétel egy online panel használatával készült, ezért az esetleges kérdezőbiztosi torzításoktól mentes adatgyüjtési folyamattal dolgoztunk. Összegyüjtött adataink elemzéshez, valamint a következtetéseink megfogalmazásához a szakirodalomban is rendszeresen használt és többször is validált kvantitatív statisztikai módszereket használtunk, így a kutatói objektivitást is adottnak tekinthetjük.

Az utolsó érvényességi mutató a tartalmi érvényesség (content validity), melyet kutatásunk során a szakirodalom alapos áttanulmányozása miatt adottnak tekintünk (Neumann-Bódi, 2012). A tartalmi érvényesség azt méri, hogy egy látens változó mérésére használt manifeszt változók tartalmi és szemantikai értelemben mennyiben képesek leképezni az adott látens változó tényleges tartalmát (Weiber - Mühlhaus 2010, 128. о.).

${ }^{9}$ A látensekhez tartozó mérési változók súlyait (loadingok) a 6. számú melléklet tartalmazza. 


\subsubsection{A strukturális modell tesztelése}

A strukturális modell tesztelését - a hiányzó tapasztalatok függvényében - a vásárlók webshophoz köthető tapasztalata alapján négy különböző esetben fogjuk végrehajtani:

1. olyan vásárlók esetében, akiknek az e-szolgáltatásminőség mindegy egyes dimenziójával kapcsolatban volt tapasztalatuk, tehát mindent tudtak értékelni ( $\mathrm{N}=377$ fö);

2. olyan vásárlók esetében, akiknek hiányos tapasztalatai voltak a biztonsághoz kapcsolódó dimenzió esetében, így nem tudtak minden egyes állítást értékelni $(\mathrm{N}=123$ fó);

3. olyan vásárlók esetében, akiknek nem volt kapcsolata az ügyfélszolgálattal, így nem tudták azt értékelni ( $\mathrm{N}=207$ fó);

4. olyan vásárlók esetében, akiknek az ügyfélszolgálattal és a biztonsággal kapcsolatban is hiányos tapasztalatai voltak $(\mathrm{N}=274$ fö $) .{ }^{10}$

Minden egyes csoport esetében külön-külön megvizsgáljuk az offline-termékek, az offline-szolgáltatások, az e-termékek és az e-szolgáltatások kategóriáját.

A feltételezett struktúra tesztelése során a változók közötti útegyütthatókat, valamint azok relevanciáját vizsgáljuk. Arról, hogy a különböző útegyütthatók jelentősek-e, a következő hipotézist állítjuk fel (Henseler et al. 2009):

H0: $\beta=0$, vagyis 0 -tól nem különbözik szignifikánsan az adott együttható értéke. $\mathrm{H} 1: \beta \neq 0$

A hipotézisvizsgálat során a PLS-SEM alkalmazásakor megszokott bootstrapping módszert használtuk, és minden egyes elemzés esetében 1.000 darab mintát képeztünk.

\subsubsection{A teljes tapasztalattal rendelkezők modellje}

Kutatásunk középpontjában azok a vásárlók állnak, akik teljes képpel rendelkeznek az eszolgáltatásminőség minden egyes dimenziójáról. Az eredmények alapján megállapítható, hogy a négy különböző e-kereskedelmi szegmensben az elektronikus

\footnotetext{
${ }^{10}$ A hiányzó értékeket azért nem helyettesítjük az átlaggal, és kezeljük egyben a négy dimenziót, mert megvizsgáltuk, hogy ez a megoldás az eredményeinket szignifikánsan torzítaná. A részleteket az 7 . számú melléklet tartalmazza.
} 
szolgáltatásminőség dimenziói közül nem mindegyik bír szignifikáns hatással az elégedettség alakulására (31. táblázat).

Az észlelt minőség első vizsgált dimenziója a használt webshop konkrét megjelenítéséhez és kialakításához tartozó jellemzőket fedi le, úgymint a kinézetet, az elérhető termékek, szolgáltatások mennyiségét, a honlapon fellelhető információk mennyiségét és minőségét, valamint a felhasználói fiók létrehozását. Mind a négy e-kereskedelmi esetben megállapítható, hogy ez a dimenzió nem bír szignifikáns hatással az elégedettség alakulására ( $\operatorname{szig}_{150 f f l i n e-t e r m e ́ k}=0,468 ;$ szig $_{150 f f l i n e-s z o l g}=0,788$; szig $_{15 \mathrm{E}-\text {-termék }}=0,933$; szig $_{15 \mathrm{E}-}$ szolg $=0,384$ ), tehát a konkrét weblaphoz, vagyis a tényleges, „fizikai” webshophoz kapcsolódó dimenziók nem relevánsak az elégedettség alakulása szempontjából. ${ }^{11}$

\begin{tabular}{|l|c|c|c|c|}
\hline & $\begin{array}{c}\text { Útegyüttható } \\
\text { (Off-term) }\end{array}$ & $\begin{array}{c}\text { Útegyüttható } \\
\text { (Off-szolg) }\end{array}$ & $\begin{array}{c}\text { Útegyüttható } \\
\text { (E-term) }\end{array}$ & $\begin{array}{c}\text { Útegyüttható } \\
\text { (E-szolg) }\end{array}$ \\
\hline $\begin{array}{l}\text { Konkrét webshop minőség } \rightarrow \\
\text { Elégedettség }\end{array}$ & 0,063 & 0,051 & 0,006 & 0,149 \\
\hline Szig (p-érték) & 0,468 & 0,788 & 0,933 & 0,384 \\
\hline $\begin{array}{l}\text { Vásárlás lebonyolításának } \\
\text { minősége } \rightarrow \text { Elégedettség }\end{array}$ & $\mathbf{0 , 6 0 6 * * *}$ & $\mathbf{0 , 4 1 7 *}$ & 0,061 & 0,059 \\
\hline Szig (p-érték) & 0,000 & 0,025 & 0,605 & 0,785 \\
\hline $\begin{array}{l}\text { Ügyfélszolgálat minősége } \rightarrow \\
\text { Elégedettség }\end{array}$ & $\mathbf{0 , 4 0 7 * *}$ & 0,25 & 0,122 & $\mathbf{0 , 4 4 8 * * *}$ \\
\hline Szig (p-érték) & 0,001 & 0,263 & 0,408 & 0,000 \\
\hline Biztonság $\rightarrow$ Elégedettség & $-0,129$ & 0,24 & $\mathbf{0 , 5 8 2 * * *}$ & $\mathbf{0 , 2 8 2 *}$ \\
\hline Szig (p-érték) & 0,405 & 0,256 & 0,000 & 0,022 \\
\hline$N(f o ̈)$ & 116 & 65 & 97 & 99 \\
\hline
\end{tabular}

\section{1. táblázat: Az elektronikus-szolgáltatásminőség dimenzióinak hatása az elégedettségre: az útegyütthatók értéke és relevanciája a teljes tapasztalattal rendelkezők esetében}

Forrás: saját eredmények alapján saját szerkesztés

A vizsgált e-kereskedelmi kategóriák esetében további nem szignifikáns dimenziókkal is találkozhatunk. Az e-termékek valamint az offline-szolgáltatások vásárlásánál az ügyfélszolgálat, vagyis a céggel való kommunikáció minőségének észlelése nem bír jelentős hatással az elégedettség alakulására $\left(\beta_{35 \mathrm{E} \text {-termék }}=0,122\right.$, szig ${ }_{35 \mathrm{E} \text {-termék }}=0,408$; $\beta_{350 f f l i n e-s z o l g}=0,250$, szig $\left._{350 f f l i n e-s z o l g}=0,263\right)$. Az e-szolgáltatások és e-termékek esetében a vásárlás lebonyolitásának minősége nem releváns az elégedettség szempontjából ( $\beta_{25 \mathrm{E}-}$ szolg $=0,059, \quad$ szig $_{25 \mathrm{E}-\mathrm{szolg}}=0,785 ; \quad \beta_{25 \mathrm{E}-\text { termék }}=0,061, \quad$ szig $\left._{25 \mathrm{E}-\text { termék }}=0,605\right)$. Az offlinetermékek és szolgáltatások esetében pedig a biztonság, vagyis a fizetés és a személyes adatok védelméhez kapcsolódó dimenzió észlelt minősége nem bír szignifikáns hatással

${ }^{11} \mathrm{Az}$ indirekt kapcsolatokhoz kapcsolódó útegyütthatókat a 8. számú melléklet tartalmazza. 


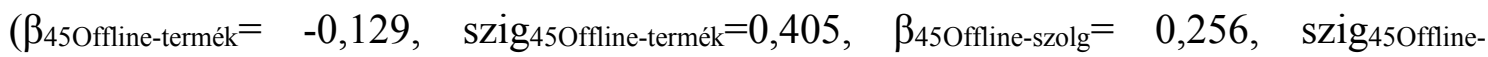
szolg $=0,266$ ), tehát megállapíthatjuk, hogy az offline teljesítéssel lebonyolított vásárlások esetében az elégedettség alakulása szempontjából a biztonság nem egy kulcsdimenzió.

A legerősebb útegyütthatóval az offline-termékek és -szolgáltatások esetében is a vásárlás lebonyolításához kapcsolódó dimenzió rendelkezik ( $\beta_{250 f f l i n e-t e r m e ́ k}=0,606$, szig $250 f f l i n e-$ termék $=0,000 ; \beta_{150 \text { ffline-szolg }}=0,417$, szig $\left.{ }_{150 f f l i n e-s z o l g}=0,025\right)$, sőt az offline-szolgáltatások esetében ez az egyedüli szignifikáns dimenzió. Az e-termékek esetében a biztonság, az eszolgáltatásoknál pedig az ügyfélszolgálat szignifikáns $\left(\beta_{45 \mathrm{E}-t \text { termék }}=0,582, \quad\right.$ szig $45 \mathrm{E}$ -

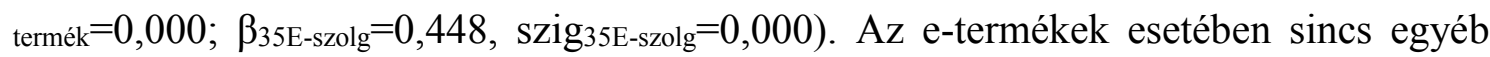
szignifikáns dimenzió.

Az eredmények alapján tehát megállapítható, hogy a Francis (2009) által megalkotott négy-négy e-szolgáltatásminőség dimenzió közül a vizsgált e-kereskedelmi esetekben csak egy (offline-szolgáltatások, e-termékek) vagy két (offline-termékek, eszolgáltatások) látenshez tartozó észlelt minőségérték bír releváns hatással az elégedettség alakulására 5\%-os szignifikanciaszint mellett ${ }^{12}$.

A strukturális modell értékelése során ki kell még emelnünk a Cohen-féle $\mathrm{f}^{2}$ mutatót (1988), mely azt mutatja, hogy egy kapcsolat, vagyis út megszüntetésével hogyan alakul egy adott endogén változó magyarázott varianciája.

Mindkettőre igaz, hogy ha a mutató értéke 0,35-nál nagyobb, akkor az adott hatás/elörejelző képesség jelentős az endogén változó szempontjából. Amennyiben 0,150,35 között van, akkor közepes, míg 0,02-0,15 közötti érték esetében gyenge hatásról beszélünk (Cohen 1988).

$$
f^{2}=\frac{\mathrm{R}_{\text {included }}^{2}-\mathrm{R}_{\text {excluded }}^{2}}{1-\mathrm{R}_{\text {included }}^{2}}
$$

ahol $\mathrm{R}^{2}$ included a négyzetes korrelációs együttható a vizsgált kapcsolatot tartalmazó modell esetében, míg $\mathrm{R}^{2}$ excluded a négyzetes korrelációs együttható az adott kapcsolatot nem tartalmazó modell esetében.

${ }^{12}$ Az eredmények 90\%-os megbízhatóság (10\%-os szignifikanciaszint) mellett is ugyanezek. 
$\mathrm{Az} \mathrm{f}^{2}$ mutató jelen esetben csak a minőségészleléshez kapcsolódó dimenziók esetében értelmezhetőek.

Az eredmények alapján megállapítható, hogy az offline-termékek esetében a szignifikáns, látens exogén változók közül a vásárlás lebonyolításának minősége erős hatással, míg az ügyfélszolgálat minősége gyenge hatással bír az elégedettség magyarázott varianciájának alakulására az $\mathrm{f}^{2}$ mutató alapján. Az offline-szolgáltatások esetében a csere dimenziója közepes erővel bír, míg az elektronikus szolgáltatások esetében az ügyfélszolgálat dimenzió hatása közepes, a biztonságé pedig gyenge. Az e-termékeknél a biztonság gyenge, míg az ügyfélszolgálat erős hatással bír az elégedettség magyarázott varianciájának alakulására (32. táblázat).

\begin{tabular}{|l|c|c|c|c|c|c|c|c|}
\hline & \multicolumn{2}{|c|}{ Off-termék } & \multicolumn{2}{|c|}{ Off-szolgáltatás } & \multicolumn{2}{|c|}{ E-termék } & \multicolumn{2}{|c|}{ E-szolgáltatás } \\
\hline $\begin{array}{l}\text { Konkrét webshop-minőség } \rightarrow \\
\text { Elégedettség }\end{array}$ & 0,006 & $\mathrm{Z}$ & 0,003 & $\mathrm{Z}$ & 0,000 & $\mathrm{Z}$ & 0,008 & $\mathrm{Z}$ \\
\hline $\begin{array}{l}\text { Vásárlás lebonyolításának } \\
\text { minósége } \rightarrow \text { Elégedettség }\end{array}$ & 0,460 & $\mathrm{~L}$ & 0,196 & $\mathrm{M}$ & 0,003 & $\mathrm{Z}$ & 0,001 & $\mathrm{Z}$ \\
\hline $\begin{array}{l}\text { Ügyfélszolgálat minősége } \rightarrow \\
\text { Elégedettség }\end{array}$ & 0,133 & $\mathrm{~S}$ & 0,069 & $\mathrm{~S}$ & 0,010 & $\mathrm{Z}$ & 0,307 & $\mathrm{~L}$ \\
\hline Biztonság $\rightarrow$ Elégedettség & 0,013 & $\mathrm{Z}$ & 0,066 & $\mathrm{~S}$ & 0,180 & $\mathrm{~S}$ & 0,069 & $\mathrm{~S}$ \\
\hline
\end{tabular}

$Z$ - nincs hatása, $S$-gyenge hatása van, $M$ - közepes hatása van, $L$ - erös hatása van

\section{2. táblázat: A változók közötti hatások jelentősége (az $\mathbf{f}^{\mathbf{2}}$ mutató értéke)}

Forrás: az eredmények alapján saját szerkesztés

Az elégedettség változó magyarázott varianciája mind a négy esetben közepesnek mondható: legmagasabb értékkel az offline-termékek esetében rendelkezik $\left(\mathrm{R}^{2}\right.$ offlinetermék $=74,3 \%)$, míg legalacsonyabbal az elektronikus-termékek kategóriájában $\left(\mathrm{R}^{2} \mathrm{E}\right.$ termék $=48,2 \%$ ) (33. táblázat).

\begin{tabular}{|l|c|c|c|c|}
\hline & Off-term & Off-szolg & E-term & E-szolg \\
\hline Elégedettség & $74,3 \%$ & $70,6 \%$ & $48,2 \%$ & $71,4 \%$ \\
\hline Tradicionális WOM & $92,0 \%$ & $81,2 \%$ & $84,4 \%$ & $71,6 \%$ \\
\hline E-WOM & $50,1 \%$ & $27,0 \%$ & $45,9 \%$ & $24,2 \%$ \\
\hline Újravásárlási szándék & $77,3 \%$ & $68,2 \%$ & $63,9 \%$ & $43,3 \%$ \\
\hline
\end{tabular}

\section{3. táblázat: A függő változók magyarázott varianciája (R2)}

Forrás: saját eredmények alapján saját szerkesztés

Az elégedettség hatása a vizsgált következményekre minden esetben szignifikáns. Legerősebb hatással mind a négy esetben a hagyományos továbbajánlási szándékra bír, míg a legkisebb útegyüttható az elégedettség és az e-WOM szándék között figyelhető meg (34. táblázat). A hagyományos továbbajánlási szándék valamint az újravásárlási 
szándék esetében a magyarázott variancia kielégítően alakul (43,3\% és 92,0\% között mozog), azonban ez elektronikus szájreklám esetében csak 24-50\% közötti.

\begin{tabular}{|l|c|c|c|c|}
\hline & $\begin{array}{c}\text { Útegyüttható } \\
\text { (Off-term) }\end{array}$ & $\begin{array}{c}\text { Útegyüttható } \\
\text { (Off-szolg) }\end{array}$ & $\begin{array}{c}\text { Útegyüttható } \\
\text { (E-term) }\end{array}$ & $\begin{array}{c}\text { Útegyüttható } \\
\text { (E-szolg) }\end{array}$ \\
\hline $\begin{array}{l}\text { Elégedettség } \rightarrow \text { Tradicionális } \\
\text { WOM hajlandóság }\end{array}$ & $\mathbf{0 , 9 5 9 * * *}$ & $\mathbf{0 , 9 0 1 * * *}$ & $\mathbf{0 , 9 1 9 * * *}$ & $\mathbf{0 , 8 4 6 * * *}$ \\
\hline Szig (p-érték) & 0,000 & 0,000 & 0,000 & 0,000 \\
\hline $\begin{array}{l}\text { Elégedettség } \rightarrow \\
\text { E-WOM hajlandóság }\end{array}$ & $\mathbf{0 , 7 0 8 * * *}$ & $\mathbf{0 , 5 2 * * *}$ & $\mathbf{0 , 6 7 8 * * *}$ & $\mathbf{0 , 4 9 2 * * *}$ \\
\hline Szig (p-érték) & 0,000 & 0,000 & 0,000 & 0,000 \\
\hline $\begin{array}{l}\text { Elégedettség } \rightarrow \\
\text { Újjavásárlási szándék }\end{array}$ & $\mathbf{0 , 8 7 9 * * *}$ & $\mathbf{0 , 8 2 6 * * *}$ & $\mathbf{0 , 7 9 9 * * *}$ & $\mathbf{0 , 6 5 8 * * *}$ \\
\hline Szig (p-érték) & 0,000 & 0,000 & 0,000 & 0,000 \\
\hline
\end{tabular}

34. táblázat: Az elégedettség hatása a hagyományos és e-továbbajánlási szándékra valamitn az újravásárlási hajlandóságra: az útegyütthatók értéke és relevanciája a teljes tapasztalattal rendelkezők esetében

Forrás: saját eredmények alapján saját szerkesztés

\subsubsection{A biztonsággal kapcsolatban hiányos tapasztalattal rendelkező vásárlók ( $\mathrm{N}=123$ fó)}

A mintában összesen 123 olyan válaszadó volt, aki a biztonsághoz kapcsolódó négy állítás közül legalább egyet nem tudott értékelni, mivel nem volt tapasztalata, vagy nem kísérte figyelemmel az adott jelenséget. Kutatásunk során azt a döntést hoztuk, hogy hiányos tapasztalatok esetén az elemzés során a teljes dimenziót figyelmen kívül hagyjuk $^{13}$, mivel a dimenzió egyes tételeinek elhagyása a skála validitását sértené.

A biztonsággal kapcsolatban hiányos tapasztalattal rendelkezők esetében legtöbben offline-terméket vásároltak (73 fö), és mindössze 8 fő tartozott az offline-szolgáltatást vásárlók közé, illetve 19 fő az e-terméket vásárlók közé. Habár a PLS-SEM jól kezeli a kis mintákat, mégis ez a két csoport az elemzésnél túl kicsinek bizonyult, így az ő esetükben a modellt nem tudjuk értelmezni.

A teljes tapasztalattal rendelkező csoport eredményeihez hasonlóan a konkrét webshopminőség és elégedettség közti útegyüttható itt sem bizonyult szignifikánsnak (szig 15 offterm $=0,497 ;$ szig $\left._{15 e-s z o l g}=0,755\right)$ (35. táblázat). Az offline-terméket vásárlók esetében a megmaradt két dimenzió - vagyis az ügyfélszolgálat, valamint a vásárlás

\footnotetext{
${ }^{13}$ Amennyiben a modellt lefuttatjuk úgy, hogy a hiányzó értékeket a hiányos értékeket tartalmazó dimenzió - jelen esetben a biztonság - esetében átlaggal helyettesítjük, hasonló eredményeket kapunk.
} 
lebonyolításának minősége - szignifikáns, pozitív hatással bír, és az utóbbi hatása a legjelentősebb az elégedettség szempontjából $\left(\beta_{250 f f l i n e-t e r m e ́ k}=0,512\right.$, szig2 ${ }_{50 f f l i n e-}$ termék $=0,020)$. Az e-szolgáltatást vásárlók esetében csak az ügyfélszolgálat minősége bír pozitív, szignifikáns hatással az elégedettség alakulása szempontjából ( $\beta_{35 \mathrm{E}-\mathrm{szolg}}=0,572$, $\left.\operatorname{szig}_{35 \mathrm{E}-\mathrm{szolg}}=0,003\right)$. Ezek a változók a teljes tapasztalattal rendelkezők esetében is hasonlóan alakultak.

\begin{tabular}{|c|c|c|c|c|}
\hline & $\begin{array}{l}\text { Útegyüttható } \\
\text { (Off-term) }\end{array}$ & $\begin{array}{l}\text { Útegyüttható } \\
\text { (Off-szolg) }\end{array}$ & $\begin{array}{c}\text { Útegyüttható } \\
\text { (E-term) }\end{array}$ & $\begin{array}{c}\text { Útegyüttható } \\
\text { (E-szolg) }\end{array}$ \\
\hline $\begin{array}{l}\text { Konkrét webshop-minőség } \rightarrow \\
\text { Elégedettség }\end{array}$ & 0,064 & N.A. & N.A. & $-0,064$ \\
\hline Szig (p-érték) & 0,497 & N.A. & N.A. & 0,755 \\
\hline $\begin{array}{l}\text { Vásárlás lebonyolításának } \\
\text { minősége } \rightarrow \text { Elégedettség }\end{array}$ & $0,512 * *$ & N.A. & N.A. & 0,223 \\
\hline Szig (p-érték) & 0,007 & N.A. & N.A. & 0,277 \\
\hline $\begin{array}{l}\text { Ügyfélszolgálat minősége } \rightarrow \\
\text { Elégedettség }\end{array}$ & $0,372 *$ & N.A. & N.A. & $0,572 * *$ \\
\hline Szig (p-érték) & 0,020 & N.A. & N.A. & 0,003 \\
\hline$N(f o ̈)$ & 73 & 8 & 19 & 42 \\
\hline
\end{tabular}

35. táblázat: Az elektronikus-szolgáltatásminőség dimenzióinak hatása az elégedettségre: az útegyütthatók értéke és relevanciája a biztonsággal kapcsolatban hiányos tapasztalattal rendelkező vásárlók

Forrás: saját eredmények alapján saját szerkesztés

$\mathrm{Az} \mathrm{f}^{2}$ mutató alapján ismét erős hatás figyelhető meg az offline-terméket vásárlók esetében a vásárlás lebonyolítása és az elégedettség között, míg az e-szolgáltatásoknál az ügyfélszolgálat és az elégedettség között (36. táblázat)

\begin{tabular}{|l|c|c|c|c|c|c|}
\hline & \multicolumn{2}{|c|}{ Off-termék } & Off-szolgáltatás & \multicolumn{2}{|c|}{ E-termék } & \multicolumn{2}{|c|}{ E-szolgáltatás } \\
\hline $\begin{array}{l}\text { Konkrét webshop-minőség } \rightarrow \\
\text { Elégedettség }\end{array}$ & 0,009 & $\mathrm{Z}$ & N.A & N.A & 0,003 & $\mathrm{Z}$ \\
\hline $\begin{array}{l}\text { Vásárlás lebonyolításának } \\
\text { minősége } \rightarrow \text { Elégedettség }\end{array}$ & 0,405 & $\mathrm{~L}$ & N.A & N.A & 0,033 & $\mathrm{~S}$ \\
\hline $\begin{array}{l}\text { Ügyfélszolgálat minősége } \rightarrow \\
\text { Elégedettség }\end{array}$ & 0,195 & $\mathrm{M}$ & N.A & N.A & 0,494 & $\mathrm{~L}$ \\
\hline
\end{tabular}

$Z$ - nincs hatása, $S$ - gyenge hatása van, $M$ - közepes hatása van, $L$ - erös hatása van

36. táblázat: A változók közötti hatások jelentősége (az f $\mathbf{f}^{2}$ mutató értéke) biztonsággal kapcsolatban hiányos tapasztalattal rendelkezők

Forrás: az eredmények alapján saját szerkesztés

Az elégedettség magyarázott varianciája szinte ugyanúgy alakul az offline-terméket vásárlók esetében, mint az előző esetben $\left(\mathrm{R}^{2}{ }_{\text {offline-termék }}=79,2 \%\right)$, ami nem meglepő, hiszen a korábbi esetben sem bírt a biztonság szignifikáns hatással. Az e-szolgáltatások esetében azonban jelentős csökkenés figyelhető meg $(\Delta=28,5 \%)$, tehát a biztonság dimenziójának 
elhagyása - mely a korábbi esetben szignifikáns hatással bírt - jelentős csökkenést eredményez az elégedettség alakulásának magyarázatában (37. táblázat).

\begin{tabular}{|l|c|c|c|c|}
\hline & Off-term & Off-szolg & E-term & E-szolg \\
\hline Elégedettség & $79,2 \%$ & N.A. & N.A. & $42,9 \%$ \\
\hline Tradicionális WOM & $79,2 \%$ & N.A. & N.A. & $65,6 \%$ \\
\hline E-WOM & $35,7 \%$ & N.A. & N.A. & $25,7 \%$ \\
\hline Újravásárlási szándék & $31,9 \%$ & N.A. & N.A. & $31,0 \%$ \\
\hline
\end{tabular}

\section{7. táblázat: A függő változók magyarázott varianciája $\left(\mathbf{R}^{\mathbf{2}}\right)$ - biztonsággal} kapcsolatban hiányos tapasztalattal rendelkezők

Forrás: saját eredmények alapján saját szerkesztés

Az elégedettség következményei esetében az útegyütthatók a teljes mintához hasonlóan alakulnak (38. táblázat): minden kapcsolat szignifikáns, és a legerősebb kapcsolat mindkét esetben az elégedettség és a hagyományos továbbajánlási szándék között figyelhető meg ( $\left.\beta_{56 \text { Offline-termék }}=0,890 ; \beta_{56 \mathrm{E}-\mathrm{szolg}}=0,810\right)$. Eltérés a teljes tapasztalattal rendelkezőkhöz viszonyítva az offline-terméket vásárlóknál figyelhető meg, mivel jelen esetben a második legerősebb kapcsolat az elégedettség és az e-WOM között áll fenn $\left(\beta_{570 f f l i n e-t e r m e ́ k}=0,598\right)$. Ugyancsak eltérés, hogy az elégedettség és az újravásárlási szándék közötti útegyüttható hasonlóan alakul a két csoportnál, míg korábban az offlineterméket vásárlóknál jelentősen magasabb volt.

\begin{tabular}{|l|c|c|c|c|}
\hline & $\begin{array}{c}\text { Útegyüttható } \\
(\mathbf{O f f - t e r m )}\end{array}$ & $\begin{array}{c}\text { Útegyüttható } \\
\text { (Off-szolg) }\end{array}$ & $\begin{array}{c}\text { Útegyüttható } \\
\text { (E-term) }\end{array}$ & $\begin{array}{c}\text { Útegyüttható } \\
\text { (E-szolg) }\end{array}$ \\
\hline $\begin{array}{l}\text { Elégedettség } \rightarrow \text { Tradicionális } \\
\text { WOM hajlandóság }\end{array}$ & $\mathbf{0 , 8 9 0 * * *}$ & N.A. & N.A. & $\mathbf{0 , 8 1 0 * * *}$ \\
\hline Szig (p-érték) & 0,000 & N.A. & N.A. & 0,000 \\
\hline $\begin{array}{l}\text { Elégedettség } \rightarrow \\
\text { E-WOM hajlandóság }\end{array}$ & $\mathbf{0 , 5 9 8 * * *}$ & N.A. & N.A. & $\mathbf{0 , 5 0 7 * * *}$ \\
\hline Szig (p-érték) & 0,000 & N.A. & N.A. & 0,000 \\
\hline $\begin{array}{l}\text { Elégedettség } \rightarrow \\
\text { Újravásárlási szándék }\end{array}$ & $\mathbf{0 , 5 6 4 * * *}$ & N.A. & N.A. & $\mathbf{0 , 5 5 7 * * *}$ \\
\hline Szig (p-érték) & 0,000 & N.A. & N.A. & 0,000 \\
\hline
\end{tabular}

38. táblázat: Az elégedettség hatása a hagyományos és e-továbbajánlási szándékra valamint az újravásárlási hajlandóságra: az útegyütthatók értéke és relevanciája a biztonsággal kapcsolatban hiányos tapasztalattal rendelkezők esetében

Forrás: saját eredmények alapján saját szerkesztés

Az elégedettségkövetkezmények magyarázott varianciája jelentősen alacsonyabb, mint a hiánytalan tapasztalattal rendelkezőknél, kivéve az elektronikus WOM-ot az eszolgáltatások esetében, ahol szinte azonos az R2 érték. A legnagyobb különbség az 
offline-terméket vásárlók esetében figyelhető meg az újravásárlási szándék esetében $(\Delta=45,4 \%)$.

\subsubsection{Az ügyfélszolgálattal kapcsolatban hiányos tapasztalattal rendelkező vásárlók (N=207 fó)}

Kutatásunkban 207 olyan online vásárló vett részt, akinek nem volt teljes tapasztalata az ügyfélszolgálattal kapcsolatban, vagyis az ide tartozó öt állítás közül legalább egyet nem tudott érdemben értékelni. Az ő esetükben az elemzés során az e-szolgáltatásminőség dimenziói közül az ügyfélszolgálatot kihagyjuk. Az ügyfélszolgálattal kapcsolatban hiányos tapasztalattal rendelkezők többsége az e-terméket és e-szolgáltatást vásárlók (63 és 61 fö) közül került ki.

\begin{tabular}{|c|c|c|c|c|}
\hline & $\begin{array}{l}\text { Útegyüttható } \\
\text { (Off-term) }\end{array}$ & $\begin{array}{l}\text { Útegyüttható } \\
\text { (Off-szolg) }\end{array}$ & $\begin{array}{l}\text { Útegyüttható } \\
\text { (E-term) }\end{array}$ & $\begin{array}{l}\text { Útegyüttható } \\
\text { (E-szolg) }\end{array}$ \\
\hline $\begin{array}{l}\text { Konkrét webshop-minőség } \rightarrow \\
\text { Elégedettség }\end{array}$ & 0,102 & 0,021 & 0,103 & $-0,018$ \\
\hline Szig (p-érték) & 0,500 & 0,896 & 0,412 & 0,909 \\
\hline $\begin{array}{l}\text { Vásárlás lebonyolításának } \\
\text { minősége } \rightarrow \text { Elégedettség }\end{array}$ & $0,575 * * *$ & 0,362 & $-0,242$ & 0,419 \\
\hline Szig (p-érték) & 0,000 & 0,139 & 0,308 & 0,098 \\
\hline Biztonság $\rightarrow$ Elégedettség & 0,165 & $0,442 *$ & $0,711 * * *$ & 0,418* \\
\hline Szig (p-érték) & 0,242 & 0,045 & 0,000 & 0,046 \\
\hline$N\left(f_{o \prime \prime}^{\prime \prime}\right)$ & 53 & 30 & 63 & 61 \\
\hline
\end{tabular}

39. táblázat: Az elektronikus-szolgáltatásminőség dimenzióinak hatása az elégedettségre: az útegyütthatók értéke és relevanciája az ügyfélszolgálattal kapcsolatban hiányos tapasztalattal rendelkező vásárlók

Forrás: saját eredmények alapján saját szerkesztés

Az útegyütthatókat megvizsgálva megállapítható, hogy a konkrét webshop-minőség dimenziója továbbra sem bír szignifikáns hatással az elégedettség alakulása szempontjából (39. táblázat). A vizsgált e-kereskedelmi kategóriákban jelen esetben egyegy szignifikáns látenssel találkozhatunk. Az offline-termékek esetében továbbra is a vásárlás lebonyolításának minőség bír szignifikáns hatással $\left(\beta_{250 f f l i n e-t e r m e ́ k}=0,575\right)$, míg az összes többi esetben a biztonság ( $\left.\beta_{450 f f l i n e-s z o l g}=0,442 ; \beta_{45 \mathrm{E}-\text { termék }}=0,811 ; \beta_{45 \mathrm{E}-\mathrm{szolg}}=0,418\right)$. Különbség a teljes tapasztalattal rendelkezőkhöz viszonyítva az offline-szolgáltatások esetében figyelhető meg: míg korábban a vásárlás lebonyolítása bírt szignifikáns hatással, addig jelen esetben a biztonság befolyásoló ereje releváns. Ennek egyik oka az lehet, hogy míg korábban volt valamilyen személyes tapasztalat az ügyfélszolgálattal, így nagyobb bizalom alakult ki a vásárlókban a szolgáltatatóval szemben (pl. hogy a lefoglalt szoba 
tényleg a rendelkezésükre fog állni), az ilyen tapasztalattal nem rendelkezők esetében a webshop észlelt biztonságában tükröződhet a kétely.

A hatások relevanciáját megvizsgálva megállapíthatjuk, hogy a szignifikáns dimenziók erős vagy közepes hatással bírnak az elégedettség alakulására. Meglepetést okozott az offline-szolgáltatások esetében a vásárlás lebonyolítása dimenzió, amely a t-próba alapján nem számít szignifikánsnak, míg az f² mutató alapján hatása közepesnek tekinthető (40. táblázat).

\begin{tabular}{|l|c|c|c|c|c|c|c|c|}
\hline & \multicolumn{2}{|c|}{ Off-termék } & Off-szolgáltatás & \multicolumn{2}{|c|}{ E-termék } & \multicolumn{2}{c|}{ E-szolgáltatás } \\
\hline $\begin{array}{l}\text { Konkrét webshop-minőség } \\
\rightarrow \text { Elégedettség }\end{array}$ & 0,011 & $\mathrm{Z}$ & 0,001 & $\mathrm{Z}$ & 0,016 & $\mathrm{Z}$ & 0,000 & $\mathrm{Z}$ \\
\hline $\begin{array}{l}\text { Vásárlás lebonyolításának } \\
\text { minősége } \rightarrow \text { Elégedettség }\end{array}$ & 0,474 & $\mathrm{~L}$ & 0,162 & $\mathrm{M}$ & 0,065 & $\mathrm{~S}$ & 0,125 & $\mathrm{~S}$ \\
\hline Biztonság $\rightarrow$ Elégedettség & 0,031 & $\mathrm{~S}$ & 0,186 & $\mathrm{M}$ & 0,578 & $\mathrm{~L}$ & 0,205 & $\mathrm{M}$ \\
\hline
\end{tabular}

40. táblázat: A változók közötti hatások jelentősége (az $\mathbf{f}^{2}$ mutató értéke) $-\mathbf{a z}$ ügyfélszolgálattal kapcsolatban hiányos tapasztalattal rendelkezők

Forrás: az eredmények alapján saját szerkesztés

A teljes tapasztalattal rendelkezőkhöz viszonyítva az elégedettség magyarázott varianciája alacsonyabban alakul mind a négy esetben (41. táblázat), tehát az ügyfélszolgálat dimenziója jelentős az elégedettség alakulása szempontjából. Az eszolgáltatások esetében jelen esetben jobb eredménnyel találkozhatunk, mint a biztonsággal kapcsolatban hiányos tapasztalattal rendelkezők esetében $(\Delta=14,8 \%)$.

\begin{tabular}{|l|c|c|c|c|}
\hline & Off-term & Off-szolg & E-term & E-szolg \\
\hline Elégedettség & $53,5 \%$ & $56,1 \%$ & $37,9 \%$ & $57,8 \%$ \\
\hline Tradicionális WOM & $55,3 \%$ & $67,8 \%$ & $80,4 \%$ & $53,2 \%$ \\
\hline E-WOM & $6,2 \%$ & $4,8 \%$ & $6,4 \%$ & $16,7 \%$ \\
\hline Újravásárlási szándék & $12,7 \%$ & $28,9 \%$ & $17,6 \%$ & $35,3 \%$ \\
\hline
\end{tabular}

41. táblázat: A függő változók magyarázott varianciája $\left(\mathbf{R}^{\mathbf{2}}\right)-\mathbf{a z}$ ügyfélszolgálattal kapcsolatban hiányos tapasztalattal rendelkezők

Forrás: saját eredmények alapján saját szerkesztés

Az elégedettség és következményei közötti útegyütthatók értéke jelen esetben is alacsonyabban alakult, mint a hiánytalan tapasztalattal rendelkezőknél. A legnagyobb különbség az e-WOM és az újravásárlási szándék esetében figyelhető meg, kivéve az eszolgáltatások esetét, ahol kisebb eltérés érzékelhető. A legnagyobb meglepetés azonban az offline-szolgáltatások esetében jelentkezik, amikor is a kutatásunk során alkalmazott vonatkozó feltétel mellett az elégedettség és az e-WOM közötti útegyüttható nem számít 


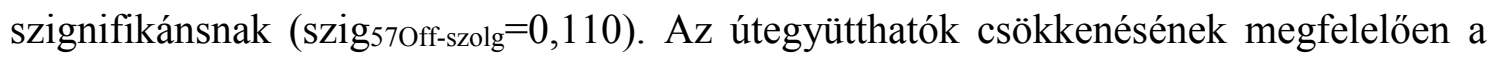
magyarázott varianciahányadok is jelentősen visszaestek. Ezek alapján láthatjuk, hogy az ügyfélszolgálat dimenziójának figyelmen kívül hagyása jelentős változásokat okoz a modellben. ${ }^{14}$ (42. táblázat)

\begin{tabular}{|l|c|c|c|c|}
\hline & $\begin{array}{c}\text { Útegyüttható } \\
\text { (Off-term) }\end{array}$ & $\begin{array}{c}\text { Útegyüttható } \\
\text { (Off-szolg) }\end{array}$ & $\begin{array}{c}\text { Útegyüttható } \\
\text { (E-term) }\end{array}$ & $\begin{array}{c}\text { Útegyüttható } \\
\text { (E-szolg) }\end{array}$ \\
\hline $\begin{array}{l}\text { Elégedettség } \rightarrow \\
\text { Tradicionális WOM }\end{array}$ & $\mathbf{0 , 7 4 9 * * *}$ & $\mathbf{0 , 8 2 4 * * *}$ & $\mathbf{0 , 8 9 9 * * *}$ & $\mathbf{0 , 7 2 9} * * *$ \\
\hline $\begin{array}{l}\text { Szig (p-érték) } \\
\text { Elégedettség } \rightarrow \\
\text { E-WOM hajlandóság }\end{array}$ & 0,000 & 0,000 & 0,000 & 0,000 \\
\hline Szig (p-érték) & $\mathbf{0 , 2 8 3 *}$ & $\mathbf{0 , 2 1 8}$ & $\mathbf{0 , 2 8 0 * *}$ & $\mathbf{0 , 4 0 8 * * *}$ \\
\hline $\begin{array}{l}\text { Elégedettség } \rightarrow \\
\text { Újravásárlási szándék }\end{array}$ & 0,012 & 0,110 & 0,008 & 0,000 \\
\hline Szig (p-érték) & $0,379 *$ & $\mathbf{0 , 5 3 7 *}$ & $\mathbf{0 , 4 3 6 *}$ & $\mathbf{0 , 5 9 4} * * *$ \\
\hline
\end{tabular}

42. táblázat: Az elégedettség hatása a hagyományos és e-továbbajánlási szándékra valamint az újravásárlási hajlandóságra: az útegyütthatók értéke és relevanciája az ügyfélszolgálattal kapcsolatban hiányos tapasztalattal rendelkezők esetében

Forrás: saját eredmények alapján saját szerkesztés

\subsubsection{A biztonsággal és az ügyfélszolgálattal kapcsolatban hiányos tapasztalattal rendelkező vásárlók $(\mathrm{N}=274$ fó)}

A tapasztalatok mértéke alapján az utolsó csoportunk, mely 274 főt számlál, azon válaszadókat tartalmazza, akiknek mind a biztonsággal, mind pedig az ügyfélszolgálattal kapcsolatban hiányos tapasztalataik voltak. Az e-szolgáltatásminőség dimenziói közül az ő esetükben tehát figyelmen kívül hagyjuk ezt a két látenst.

Az eredmények alapján az e-termékek és -szolgáltatások esetében a modellben maradt két dimenzió egyike sem bír szignifikáns hatással az elégedettség alakulására (43. táblázat), bár 10\%-os szignifikanciaszint mellet az e-termékek esetében a vásárlás minősége relevánsnak számít (szig25E-termék $=0,060$ ). Az offline-termékek esetében továbbra is a vásárlás lebonyolításának minőségéhez tartozik szignifikáns útegyüttható ( $\left.\beta_{250 f f l i n e-t e r m e ́ k}=0,436\right)$, mely dimenzió jelen szituációban az e-termékek esetében is szignifikánsnak mutatkozik $\left(\beta_{25 \mathrm{E}-t e r m e ́ k}=0,487\right)$. Az offline-szolgáltatások vásárlásakor a konkrét webshop-minőség dimenzió hatása releváns $\left(\beta_{150 f f l i n e-s z o l g}=0,374\right)$. Ez a dimenzió a korábbi esetek közül egyikben sem bírt releváns hatással.

${ }^{14}$ Amennyiben a modellt lefuttatjuk úgy, hogy a hiányzó értékeket az ügyfélszolgálat esetében átlaggal helyettesítjük, hasonlóan gyenge eredményeket kapunk. 


\begin{tabular}{|l|c|c|c|c|}
\hline & $\begin{array}{c}\text { Útegyüttható } \\
\text { (Off-term) }\end{array}$ & $\begin{array}{c}\text { Útegyüttható } \\
\text { (Off-szolg) }\end{array}$ & $\begin{array}{c}\text { Útegyüttható } \\
\text { (E-term) }\end{array}$ & $\begin{array}{c}\text { Útegyüttható } \\
\text { (E-szolg) }\end{array}$ \\
\hline $\begin{array}{l}\text { Konkrét webshop-minőség } \rightarrow \\
\text { Elégedettség }\end{array}$ & 0,131 & $\mathbf{0 , 3 7 4 *}$ & $-0,005$ & 0,363 \\
\hline Szig (p-érték) & 0,287 & 0,013 & 0,967 & 0,308 \\
\hline $\begin{array}{l}\text { Vásárlás lebonyolításának } \\
\text { minősége } \rightarrow \text { Elégedettség }\end{array}$ & $\mathbf{0 , 4 3 6 * *}$ & 0,268 & $\mathbf{0 , 4 8 7 *}$ & $-0,042$ \\
\hline Szig (p-érték) & 0,001 & 0,159 & 0,049 & 0,921 \\
\hline$N(f o)$ & 124 & 31 & 58 & 61 \\
\hline
\end{tabular}

43. táblázat: Az elektronikus-szolgáltatásminőség dimenzióinak hatása az elégedettségre: az útegyütthatók értéke és relevanciája a biztonsággal és ügyfélszolgálattal kapcsolatban hiányos tapasztalattal rendelkező vásárlók

Forrás: az eredmények alapján saját szerkesztés

Az elégedettségre ható szignifikáns változók hatása mindkét esetben közepes, sőt az etermékek esetében a vásárlás minőségének értékelése is közepes hatással bír az elégedettség alakulása szempontjából (44. táblázat).

\begin{tabular}{|l|c|c|c|c|c|c|c|c|}
\hline & \multicolumn{2}{|c|}{ Off-termék } & Off-szolgáltatás & \multicolumn{2}{c|}{ E-termék } & \multicolumn{2}{c|}{ E-szolgáltatás } \\
\hline $\begin{array}{l}\text { Konkrét webshop-minőség } \\
\rightarrow \text { Elégedettség }\end{array}$ & 0,019 & $\mathrm{Z}$ & 0,174 & $\mathrm{M}$ & 0,000 & $\mathrm{Z}$ & 0,031 & $\mathrm{~S}$ \\
\hline $\begin{array}{l}\text { Vásárlás lebonyolításának } \\
\text { minősége } \rightarrow \text { Elégedettség }\end{array}$ & 0,213 & $\mathrm{M}$ & 0,089 & $\mathrm{~S}$ & 0,273 & $\mathrm{M}$ & 0,000 & $\mathrm{Z}$ \\
\hline
\end{tabular}

44. táblázat: A változók közötti hatások jelentősége (az $\mathbf{f}^{\mathbf{2}}$ mutató értéke) - a biztonsággal és ügyfélszolgálattal kapcsolatban hiányos tapasztalattal rendelkezők

Forrás: az eredmények alapján saját szerkesztés

Mivel a jelen esetben modellünk két olyan változót sem tartalmaz, amelyek korábban relevánsnak bizonyultak az elégedettség alakulása szempontjából, így nem meglepő, hogy az elégedettség magyarázott varianciája is alacsonyabb. Ugyancsak jelentős csökkenés figyelhető meg a hiánytalan tapasztalattal rendelkezőkhöz képest az e-WOM és az újravásárlási szándék esetében. A tradicionális WOM esetében csak az e-termékeket vásárlóknál figyelhető meg jelentős csökkenés (45. táblázat).

\begin{tabular}{|l|c|c|c|c|}
\hline & Off-term & Off-szolg & E-term & E-szolg \\
\hline Elégedettség & $25,3 \%$ & $27,6 \%$ & $23,5 \%$ & $10,6 \%$ \\
\hline Tradicionális WOM & $85,3 \%$ & $83,0 \%$ & $45,9 \%$ & $77,0 \%$ \\
\hline E-WOM & $9,6 \%$ & $32,0 \%$ & $1,8 \%$ & $15,5 \%$ \\
\hline Újravásárlási szándék & $54,7 \%$ & $30,1 \%$ & $14,6 \%$ & $40,6 \%$ \\
\hline
\end{tabular}

45. táblázat: A függő változók magyarázott varianciája $\left(\mathbf{R}^{2}\right)$ - az biztonsággal és ügyfélszolgálattal kapcsolatban hiányos tapasztalattal rendelkezők

Forrás: saját eredmények alapján saját szerkesztés 
Az elégedettség következményeihez tartozó mindegyik útegyüttható szignifikáns. Legnagyobb visszaesés az e-termékek esetében figyelhető meg mind a három következmény esetében, továbbá az offline-terméket vásárlók esetében az elektronikus WOM-hoz tartozó hatás is jelentősen csökkent (46. táblázat).

\begin{tabular}{|l|c|c|c|c|}
\hline & $\begin{array}{c}\text { Útegyüttható } \\
\text { (Off-term) }\end{array}$ & $\begin{array}{c}\text { Útegyüttható } \\
\text { (Off-szolg) }\end{array}$ & $\begin{array}{c}\text { Útegyüttható } \\
\text { (E-term) }\end{array}$ & $\begin{array}{c}\text { Útegyüttható } \\
\text { (E-szolg) }\end{array}$ \\
\hline $\begin{array}{l}\text { Elégedettség } \rightarrow \\
\text { Tradicionális WOM }\end{array}$ & $\mathbf{0 , 9 2 4 * * *}$ & $\mathbf{0 , 9 1 1 * * *}$ & $\mathbf{0 , 6 7 8 * * *}$ & $\mathbf{0 , 8 7 8 * * *}$ \\
\hline Szig (p-érték) & 0,000 & 0,000 & 0,000 & 0,000 \\
\hline $\begin{array}{l}\text { Elégedettség } \rightarrow \\
\text { E-WOM hajlandóság }\end{array}$ & $\mathbf{0 , 3 1 0 * * *}$ & $\mathbf{0 , 5 6 6 * * *}$ & $\mathbf{0 , 1 3 3 * * *}$ & $\mathbf{0 , 3 9 4 * * *}$ \\
\hline Szig (p-érték) & 0,000 & 0,000 & 0,000 & 0,001 \\
\hline $\begin{array}{l}\text { Elégedettség } \rightarrow \\
\text { Újravásárlási szándék }\end{array}$ & $\mathbf{0 , 7 4 0 * * *}$ & $\mathbf{0 , 5 4 8 * * *}$ & $\mathbf{0 , 3 8 3 * * *}$ & $\mathbf{0 , 6 3 7 * * *}$ \\
\hline Szig (p-érték) & 0,000 & 0,000 & 0,000 & 0,000 \\
\hline
\end{tabular}

46. táblázat: Az elégedettség hatása a hagyományos és e-továbbajánlási szándékra valamint az újravásárlási hajlandóságra: az útegyütthatók értéke és relevanciája a biztonsággal és ügyfélszolgálattal kapcsolatban hiányos tapasztalattal rendelkezők esetében

Forrás: saját eredmények alapján saját szerkesztés

\subsection{A szegmensek közötti különbségek értékelése többcsoportos elemzéssel (MGA)}

\subsubsection{A teljes tapasztalattal rendeletezők értékelése (MGA)}

Amellett, hogy megismerjük az e-szolgáltatásminőség dimenzióinak hatását az elégedettségre és annak következményeire, kutatásunk fö célja, hogy feltérképezzük, vajon a felállított négy e-kereskedelmi kategóriában a vizsgált modell (lásd 18. ábra a feltételezett modellröl) útegyütthatói szignifikánsan különböznek-e, kvázi az egész modellben egyfajta moderáló hatással bír-e az a tény, hogy az egyén milyen jellegü terméket vagy szolgáltatást vásárolt. Annak ellenőrzésére, hogy a modell több csoport egyidejü vizsgálata mellett hogyan alakul, a többcsoportos elemzési módszer (multi group analysis, a továbbiakban: MGA) szolgál (Sarstedt et al. 2011).

Kutatásunk a során a vizsgált e-kereskedelmi szegmensekben az e-szolgáltatásminőség dimenzióinak mérése eltérő változókkal és indikátorszámokkal került megvalósításra, ezért a modell inputjaként szolgáló e-szolgáltatásminőség dimenziókat a korábbi útelemzés során előállított látens értékekkel helyettesítjük, kvázi mindegy egyes 
válaszadó esetében az indikátorokhoz rendelt súlyok által meghatározott súlyozott, sztenderdizált értékeket használjuk.

\begin{tabular}{|c|c|c|c|c|}
\hline & $\begin{array}{l}\text { Útegyüttható } \\
\text { (Off-termék) }\end{array}$ & $\begin{array}{l}\text { Útegyüttható } \\
\text { (Off-szolg) }\end{array}$ & $\begin{array}{l}\text { Útegyüttható } \\
\text { (E-termék) }\end{array}$ & $\begin{array}{l}\text { Útegyüttható } \\
\text { (E-szolg) }\end{array}$ \\
\hline $\begin{array}{l}\text { Konkrét webshop- } \\
\text { minőség } \rightarrow \text { Elégedettség }\end{array}$ & 0,063 & 0,051 & 0,006 & 0,149 \\
\hline PLS MGA p-érték & $\begin{array}{c}\text { Nincs } \\
\text { szignifikáns } \\
\text { különbség }\end{array}$ & $\begin{array}{c}\text { Nincs } \\
\text { szignifikáns } \\
\text { különbség }\end{array}$ & $\begin{array}{l}\text { Nincs szignifikáns } \\
\text { különbség }\end{array}$ & $\begin{array}{l}\text { Nincs szignifikáns } \\
\text { különbség }\end{array}$ \\
\hline $\begin{array}{l}\text { Vásárlás lebonyolítás } \rightarrow \\
\text { Elégedettség }\end{array}$ & $\underline{0,606 * * *}$ & $0,417^{*}$ & $\underline{0,061}$ & $\underline{\mathbf{0 , 0 5 9}}$ \\
\hline PLS MGA p-érték & $\begin{array}{c}\text { E-szolg }(0,989) \\
\text { E-termék }(0,999)\end{array}$ & $\begin{array}{c}\text { Nincs } \\
\text { szignifikáns } \\
\text { különbség }\end{array}$ & Off-termék $(0,999)$ & Off-termék $(0,989)$ \\
\hline $\begin{array}{l}\text { Biztonság } \rightarrow \\
\text { Elégedettség }\end{array}$ & $\underline{-0,129}$ & 0,24 & $\underline{0,582 * * *}$ & $0,282 *$ \\
\hline PLS MGA p-érték & E-termék $(0,003)$ & $\begin{array}{c}\text { Nincs } \\
\text { szignifikáns } \\
\text { különbség }\end{array}$ & Off-termék $(0,003)$ & $\begin{array}{l}\text { Nincs szignifikáns } \\
\text { különbség }\end{array}$ \\
\hline $\begin{array}{l}\text { Ügyfélszolgálat } \rightarrow \\
\text { Elégedettség }\end{array}$ & $0,407 * *$ & 0,25 & $\underline{0,122}$ & $\underline{0,448 * * *}$ \\
\hline PLS MGA p-érték & $\begin{array}{c}\text { Nincs } \\
\text { szignifikáns } \\
\text { különbség } \\
\end{array}$ & $\begin{array}{c}\text { Nincs } \\
\text { szignifikáns } \\
\text { különbség } \\
\end{array}$ & E-szolg $(0,049)$ & E-termék $(0,049)$ \\
\hline $\begin{array}{l}\text { Elégedettség } \rightarrow \\
\text { Tradicionális WOM }\end{array}$ & $\underline{0,959 * * *}$ & $0,901 * * *$ & $0,919 * * *$ & $\underline{0,846 * * *}$ \\
\hline PLS MGA p-érték & E-szolg $(0,997)$ & $\begin{array}{c}\text { Nincs } \\
\text { szignifikáns } \\
\text { különbség } \\
\end{array}$ & $\begin{array}{l}\text { Nincs szignifikáns } \\
\text { különbség }\end{array}$ & Off-termék $(0,997)$ \\
\hline $\begin{array}{l}\text { Elégedettség } \rightarrow \\
\text { E-WOM hajlandóság }\end{array}$ & $\underline{0,708 * * *}$ & $0,52 * * *$ & $0,678^{* * *}$ & $\underline{0,492 * * *}$ \\
\hline PLS MGA p-érték & E-szolg $(0,962)$ & $\begin{array}{c}\text { Nincs } \\
\text { szignifikáns } \\
\text { különbség }\end{array}$ & $\begin{array}{l}\text { Nincs szignifikáns } \\
\text { különbség }\end{array}$ & Off-termék $(0,962)$ \\
\hline $\begin{array}{l}\text { Elégedettség } \rightarrow \\
\text { Újravásárlási szándék }\end{array}$ & $\underline{0,879 * * *}$ & $\underline{\mathbf{0 , 8 2 6} * * *}$ & $0,799 * * *$ & $\underline{0,658 * * *}$ \\
\hline PLS MGA p-érték & E-szolg $(0,994)$ & E-szolg $(0,956)$ & $\begin{array}{l}\text { Nincs szignifikáns } \\
\text { különbség }\end{array}$ & $\begin{array}{l}\text { Off-termék }(0,994) \\
\text { Off-szolg }(0,956)\end{array}$ \\
\hline
\end{tabular}

\section{7. táblázat: Az e-kereskedelmi szegmensek közötti páronkénti különbségek - teljes tapasztalattal rendelkezők}

Forrás: az eredmények alapján saját szerkesztés

Korábban láthattuk, hogy a különböző e-kereskedelmi kategóriákban a feltételezett eszolgáltatásminőségi dimenziók hatásának relevanciája eltérően alakul, mely különbségeket ismét szeretnénk górcső alá venni. Az offline-termékek esetében a vásárlás lebonyolításának minősége és az elégedettség közötti útegyüttható szignifikánsan magasabb, mint az e-szolgáltatások és e-termékek esetében, míg a biztonság dimenziójához tartozó útegyüttható az e-termékek esetében szignifikánsabb magasabb, mint az offline-termékeknél. A minőségészlelés során tehát két változónál 
figyelhető meg szignifikáns különbség, azonban ez mindkét esetben olyan útegyütthatónál áll fenn, amely az egyik szegmensben szignifikáns, míg a másikban nem. $\mathrm{Az}$ elégedettség magyarázott varianciájában azonban már releváns különbségek mutatkoznak: az e-termékeknél az elégedettség magyarázott varianciája szignifikánsan alacsonyabb, mint az offline-termékeknél (szig=0,003) (47. táblázat).

Az elégedettség és következményei esetében az offline-termékekhez és az eszolgáltatásokhoz tartozó útegyütthatók szignifikánsan különböznek: az offline-termékek esetében minden útegyüttható szignifikánsan magasabb, tehát az elégedettségi szint változásával szignifikánsan nagyobb változás mutatkozik a következményekben. Az eszolgáltatásokhoz tartozó útegyüttható az elégedettség és az újravásárlási szándék között az offline-szolgáltatásokétól is szignifikánsan alacsonyabb. Ennek következtében a hagyományos WOM, az e-WOM és az újravásárlási szándék magyarázott varianciája is szignifikánsan alacsonyabb az e-szolgáltatások esetében, mint a korábban megnevezett esetekben (48. táblázat).

\begin{tabular}{|r|c|c|c|c|c|c|}
\hline & $\begin{array}{c}\text { p-érték } \\
\text { (E-szolg vs } \\
\text { E-term) }\end{array}$ & $\begin{array}{c}\text { p-érték } \\
\text { (E-szolg vs } \\
\text { Off-szolg) }\end{array}$ & $\begin{array}{c}\text { p-érték } \\
\text { (E-szolg vs } \\
\text { Off-term) }\end{array}$ & $\begin{array}{c}\text { p-érték } \\
\text { (E-term vs } \\
\text { Off-szolg) }\end{array}$ & $\begin{array}{c}\text { p-érték } \\
\text { (E-term vs } \\
\text { Off-term) }\end{array}$ & $\begin{array}{c}\text { p-érték } \\
\text { (Off-szolg vs } \\
\text { Off-term) }\end{array}$ \\
\hline $\mathbf{R}^{2}$ SAT & 0,126 & 0,917 & 0,374 & 0,218 & 0,030 & 0,356 \\
\hline $\mathbf{R}^{2}$ tr. WOM & 0,181 & 0,459 & 0,012 & 0,745 & 0,124 & 0,177 \\
\hline $\mathbf{R}^{2} \mathbf{E}-\mathbf{W O M}$ & 0,115 & 0,837 & 0,075 & 0,218 & 0,786 & 0,166 \\
\hline $\mathbf{R}^{2} \mathbf{B I}$ & 0,154 & 0,097 & 0,006 & 0,766 & 0,262 & 0,442 \\
\hline
\end{tabular}

\section{8. táblázat: A függő változók magyarázott varianciája $\left(\mathbf{R}^{2}\right)$ közti különbségek a} szegmensek között - teljes tapasztalattal rendelkezők

Forrás: saját eredmények alapján saját szerkesztés

Összefoglalva megállapíthatjuk, hogy az elégedettség magyarázott varianciája az offlinetermékek esetében a legmagasabb, míg az e-termékeknél a legalacsonyabb, és ezen értékek szignifikánsan különböznek. Mindemellett az elégedettség következményeinek esetében a legerősebb útegyütthatókkal rendelkező offline-termékek csoportjának útegyütthatói minden esetben szignifikánsan eltérnek a legalacsonyabb értékekkel rendelkező e-szolgáltatásokétól. A többi szegmens esetében csak egy esetben (offlineszolgáltatás - e-szolgáltatás) figyelhető meg szignifikáns különbség. Tehát az offline kategóriába tartozó termékek és szolgáltatások esetében nincsen szignifikáns különbség a felvázolt modellben a teljes tapasztalattal rendelkezők esetében, míg az offline-online jószágok, valamint az e-termékek és e-szolgáltatások esetében megfigyelhetőek szignifikáns eltérések. 


\subsubsection{A biztonsággal kapcsolatban hiányos tapasztalattal rendelkező vásárlók (MGA)}

Mint korábban bemutattuk, a biztonsággal kapcsolatban hiányos tapasztalattal rendelkezők esetében mindössze két e-kereskedelmi kategóriában tudtunk a modellt lefuttatni. Habár a modellben megfigyelhetőek különbségek, mégis az MGA alapján nem figyelhető meg szignifikáns eltérés az offline-terméket és e-szolgáltatást vásárlók között (49 - 50.táblázat).

\begin{tabular}{|c|c|c|c|c|}
\hline & $\begin{array}{c}\text { Útegyüttható } \\
\text { (Off-term) }\end{array}$ & $\begin{array}{l}\text { Útegyüittható } \\
\text { (Off-szolg) }\end{array}$ & $\begin{array}{l}\text { Útegyüttható } \\
\text { (E-term) }\end{array}$ & $\begin{array}{l}\text { Útegyüttható } \\
\text { (E-szolg) }\end{array}$ \\
\hline $\begin{array}{l}\text { Konkrét webshop- } \\
\text { minőség } \\
\rightarrow \quad \text { Elégedettség }\end{array}$ & 0,064 & N.A. & N.A. & $-0,064$ \\
\hline PLS MGA p-érték & $\begin{array}{l}\text { Nincs szignifikáns } \\
\text { különbség }\end{array}$ & N.A. & N.A. & $\begin{array}{l}\text { Nincs szignifikáns } \\
\text { különbség }\end{array}$ \\
\hline $\begin{array}{l}\text { Vásárlás lebonyolítása } \\
\rightarrow \text { Elégedettség }\end{array}$ & $0,512 * *$ & N.A. & N.A. & 0,223 \\
\hline PLS MGA p-érték & $\begin{array}{l}\text { Nincs szignifikáns } \\
\text { különbség }\end{array}$ & N.A. & N.A. & $\begin{array}{c}\text { Nincs szignifikáns } \\
\text { különbség }\end{array}$ \\
\hline $\begin{array}{l}\text { Biztonság } \rightarrow \\
\text { Elégedettség }\end{array}$ & $0,372 *$ & N.A. & N.A. & $0,572 * *$ \\
\hline PLS MGA p-érték & $\begin{array}{l}\text { Nincs szignifikáns } \\
\text { különbség }\end{array}$ & N.A. & N.A. & $\begin{array}{l}\text { Nincs szignifikáns } \\
\text { különbség }\end{array}$ \\
\hline $\begin{array}{l}\text { Ügyfélszolgálat } \rightarrow \\
\text { Elégedettség }\end{array}$ & $0,407 * *$ & N.A. & N.A. & $0,448 * * *$ \\
\hline PLS MGA p-érték & $\begin{array}{l}\text { Nincs szignifikáns } \\
\text { különbség } \\
\end{array}$ & N.A. & N.A. & $\begin{array}{l}\text { Nincs szignifikáns } \\
\text { különbség }\end{array}$ \\
\hline $\begin{array}{l}\text { Elégedettség } \rightarrow \\
\text { Tradicionális WOM }\end{array}$ & $0,890 * * *$ & N.A. & N.A. & $0,810 * * *$ \\
\hline PLS MGA p-érték & $\begin{array}{l}\text { Nincs szignifikáns } \\
\text { különbség }\end{array}$ & N.A. & N.A. & $\begin{array}{l}\text { Nincs szignifikáns } \\
\text { különbség } \\
\end{array}$ \\
\hline $\begin{array}{l}\text { Elégedettség } \rightarrow \\
\text { E-WOM hajlandóság }\end{array}$ & $0,598 * * *$ & N.A. & N.A. & $0,507 * * *$ \\
\hline PLS MGA p-érték & $\begin{array}{l}\text { Nincs szignifikáns } \\
\text { különbség } \\
\end{array}$ & N.A. & N.A. & $\begin{array}{l}\text { Nincs szignifikáns } \\
\text { különbség } \\
\end{array}$ \\
\hline $\begin{array}{l}\text { Elégedettség } \rightarrow \\
\text { Újravásárlási szánd. }\end{array}$ & $0,564 * * *$ & N.A. & N.A. & $0,557 * * *$ \\
\hline PLS MGA p-érték & $\begin{array}{l}\text { Nincs szignifikáns } \\
\text { különbség }\end{array}$ & N.A. & N.A. & $\begin{array}{c}\text { Nincs szignifikáns } \\
\text { különbség }\end{array}$ \\
\hline
\end{tabular}

49. táblázat: Az e-kereskedelmi szegmensek közötti páronkénti különbségek biztonsággal kapcsolatban hiányos tapasztalattal rendelkezők

Forrás: az eredmények alapján saját szerkesztés 


\begin{tabular}{|r|c|}
\hline & $\begin{array}{c}\text { p-érték } \\
\text { (E-szolg vs Off-term) }\end{array}$ \\
\hline $\mathbf{R}^{\mathbf{2}}$ SAT & 0,035 \\
\hline $\mathbf{R}^{\mathbf{2}}$ tr. WOM & 0,299 \\
\hline $\mathbf{R}^{\mathbf{2}} \mathbf{E}-\mathbf{W O M}$ & 0,617 \\
\hline $\mathbf{R}^{\mathbf{2}} \mathbf{B I}$ & 0,967 \\
\hline
\end{tabular}

50. táblázat: A függő változók magyarázott varianciája $\left(R^{2}\right)$ közti különbségek a szegmensek között - biztonsággal kapcsolatban hiányos tapasztalattal rendelkezők

Forrás: saját eredmények alapján saját szerkesztés

\begin{tabular}{|c|c|c|c|c|}
\hline & $\begin{array}{l}\text { Útegyüttható } \\
\text { (Off-term) }\end{array}$ & $\begin{array}{l}\text { Útegyüttható } \\
\text { (Off-szolg) }\end{array}$ & $\begin{array}{l}\text { Útegyüttható } \\
\text { (E-term) }\end{array}$ & $\begin{array}{l}\text { Útegyüittható } \\
\text { (E-szolg) }\end{array}$ \\
\hline $\begin{array}{l}\text { Konkrét webshop- } \\
\text { minőség } \rightarrow \text { Elégedettség }\end{array}$ & 0,102 & 0,021 & 0,103 & $-0,018$ \\
\hline PLS MGA p-érték & $\begin{array}{c}\text { Nincs } \\
\text { szignifikáns } \\
\text { különbség }\end{array}$ & $\begin{array}{c}\text { Nincs } \\
\text { szignifikáns } \\
\text { különbség }\end{array}$ & $\begin{array}{c}\text { Nincs } \\
\text { szignifikáns } \\
\text { különbség }\end{array}$ & $\begin{array}{c}\text { Nincs } \\
\text { szignifikáns } \\
\text { különbség }\end{array}$ \\
\hline $\begin{array}{l}\text { Vásárlás lebony. } \rightarrow \\
\text { Elégedettség }\end{array}$ & $\underline{0,575 * * *}$ & 0,362 & $\underline{-0,242}$ & $\underline{0,419}$ \\
\hline PLS MGA p-érték & E-termék $(0,995)$ & $\begin{array}{c}\text { Nincs } \\
\text { szignifikáns } \\
\text { különbség }\end{array}$ & $\begin{array}{c}\text { Off-termék }(0,995) \\
\text { E-szolg }(0,032)\end{array}$ & E-termék $(0,032)$ \\
\hline $\begin{array}{l}\text { Biztonság } \rightarrow \\
\text { Elégedettség }\end{array}$ & $\underline{0,165}$ & $0,442 *$ & $\underline{0,711 * * *}$ & $0,418 *$ \\
\hline PLS MGA p-érték & E-termék $(0,014)$ & $\begin{array}{c}\text { Nincs } \\
\text { szignifikáns } \\
\text { különbség } \\
\end{array}$ & Off-termék $(0,014)$ & $\begin{array}{c}\text { Nincs } \\
\text { szignifikáns } \\
\text { különbség }\end{array}$ \\
\hline $\begin{array}{l}\text { Elégedettség } \rightarrow \\
\text { Tradicionális WOM }\end{array}$ & $\underline{0,749 * * *}$ & $0,824 * * *$ & $\underline{0,899 * * *}$ & $\underline{0,729 * * *}$ \\
\hline PLS MGA p-érték & E-termék $(0,041)$ & $\begin{array}{c}\text { Nincs } \\
\text { szignifikáns } \\
\text { különbség }\end{array}$ & $\begin{array}{c}\text { Off-termék }(0,041) \\
\text { E-szolg }(0,95)\end{array}$ & E-termék $(0,95)$ \\
\hline $\begin{array}{l}\text { Elégedettség } \rightarrow \\
\text { E-WOM hajlandóság }\end{array}$ & $0,283^{*}$ & 0,218 & $0,280 * *$ & $0,408 * * *$ \\
\hline PLS MGA p-érték & $\begin{array}{c}\text { Nincs } \\
\text { szignifikáns } \\
\text { különbség } \\
\end{array}$ & $\begin{array}{c}\text { Nincs } \\
\text { szignifikáns } \\
\text { különbség } \\
\end{array}$ & $\begin{array}{c}\text { Nincs szignifikáns } \\
\text { különbség }\end{array}$ & $\begin{array}{c}\text { Nincs } \\
\text { szignifikáns } \\
\text { különbség } \\
\end{array}$ \\
\hline $\begin{array}{l}\text { Elégedettség } \rightarrow \\
\text { Újravásárlási szándék }\end{array}$ & $0,379 *$ & $0,537 *$ & $0,436^{*}$ & $0,594 * * *$ \\
\hline PLS MGA p-érték & $\begin{array}{c}\text { Nincs } \\
\text { szignifikáns } \\
\text { különbség } \\
\end{array}$ & $\begin{array}{c}\text { Nincs } \\
\text { szignifikáns } \\
\text { különbség } \\
\end{array}$ & $\begin{array}{c}\text { Nincs szignifikáns } \\
\text { különbség }\end{array}$ & $\begin{array}{c}\text { Nincs } \\
\text { szignifikáns } \\
\text { különbség }\end{array}$ \\
\hline
\end{tabular}

51. táblázat: Az e-kereskedelmi szegmensek közötti páronkénti különbségek - az ügyfélszolgálattal kapcsolatban hiányos tapasztalattal rendelkezők

Forrás: az eredmények alapján saját szerkesztés 


\subsubsection{Az ügyfélszolgálattal kapcsolatban hiányos tapasztalattal rendelkező vásárlók (MGA)}

Az ügyfélszolgálattal kapcsolatban hiányos tapasztalattal rendelkezők körében az eszolgáltatásminőség esetében az offline-szolgáltatást vásárlók eredményei nem különböznek szignifikánsan semelyik csoport eredményeitől, míg az összes többi ekereskedelmi kategória között megfigyelhetőek releváns eltérések. Az offline-terméket vásárlók körében a vásárlás lebonyolítása és az elégedettség közötti útegyüttható szignifikánsan magasabb, mint az e-termékek esetében, és ugyanez mondható el az eszolgáltatások csoportjáról. Az e-termékek esetében azonban a biztonság dimenziója bír szignifikánsan nagyobb hatással az elégedettségre. Ezek a szignifikáns különbségek azonban ismét olyan dimenziók között állnak fenn, amelyeknél az egyik útegyüttható szignifikáns, míg a másik nem. Az elégedettség magyarázott varianciájában szignifikáns különbségek jelen esetben nem figyelhetők meg (51. táblázat).

Az elégedettség következményeihez tartozó útegyütthatókat megvizsgálva találhatunk szignifikáns eltéréseket, ugyanis az elégedettség és a tradicionális WOM közötti útegyüttható az e-terméket vásárlók esetében a legmagasabb, és ez szignifikánsan eltér az e-szolgáltatást, valamint az offline-terméket vásárlók eredményétől. Ebből kiindulva a hagyományos továbbajánlási szándék magyarázott varianciája is szignifikánsan magasabb az e-termékek esetében (52. táblázat).

\begin{tabular}{|r|c|c|c|c|c|c|}
\hline & $\begin{array}{c}\text { p-érték } \\
\text { (E-szolg vs } \\
\text { E-term) }\end{array}$ & $\begin{array}{c}\text { p-érték } \\
\text { (E-szolg vs } \\
\text { Off-szolg) }\end{array}$ & $\begin{array}{c}\text { p-érték } \\
\text { (E-szolg vs } \\
\text { Off-term) }\end{array}$ & $\begin{array}{c}\text { p-érték } \\
\text { (E-term vs } \\
\text { Off-szolg) }\end{array}$ & $\begin{array}{c}\text { p-érték } \\
\text { (E-term vs } \\
\text { Off-term) }\end{array}$ & $\begin{array}{c}\text { p-érték } \\
\text { (Off-szolg vs } \\
\text { Off-term) }\end{array}$ \\
\hline $\mathbf{R}^{2}$ SAT & 0,449 & 0,945 & 0,941 & 0,535 & 0,483 & 0,998 \\
\hline $\mathbf{R}^{2}$ tr. WOM & 0,103 & 0,547 & 0,888 & 0,303 & 0,081 & 0,562 \\
\hline $\mathbf{R}^{2} \mathbf{E}$-WOM & 0,396 & 0,337 & 0,408 & 0,776 & 0,990 & 0,754 \\
\hline $\mathbf{R}^{\mathbf{2}} \mathbf{B I}$ & 0,416 & 0,830 & 0,294 & 0,746 & 0,823 & 0,637 \\
\hline
\end{tabular}

52. táblázat: A függő változók magyarázott varianciája $\left(R^{2}\right)$ közti különbségek a szegmensek között - ügyfélszolgálattal kapcsolatban hiányos tapasztalattal rendelkezők

Forrás: saját eredmények alapján saját szerkesztés

Összességében megállapíthatjuk, hogy az offline-szolgáltatást vásárlók modellje jelen szituációban egyik további e-kereskedelmi kategóriától sem tér el szignifikánsan, valamint az offline-termékek és e-szolgáltatások kategóriája sem különbözik egymástól szignifikánsan, azonban az e-terméket vásárlók minkét előbbi csoporttól szignifikánsan különböznek. 


\subsubsection{A biztonsággal és az ügyfélszolgálattal kapcsolatban hiányos tapasztalattal rendelkező vásárlók (MGA)}

Az utolsó csoportunk esetében az e-szolgáltatásminőségnek már csak két dimenzióját elemezzünk a modellünkben: a konkrét webshop-minőséget, valamint a vásárlás lebonyolításának különbségét. Szignifikáns eltérés figyelhető meg a webshop értékelése terén az offline-szolgáltatást, valamint az e-terméket vásárlók között.

\begin{tabular}{|c|c|c|c|c|}
\hline & $\begin{array}{l}\text { Útegyüttható } \\
\text { (Off-term) }\end{array}$ & $\begin{array}{l}\text { Útegyüttható } \\
\text { (Off-szolg) }\end{array}$ & $\begin{array}{l}\text { Útegyüttható (E- } \\
\text { term) }\end{array}$ & $\begin{array}{l}\text { Útegyüttható } \\
\text { (E-szolg) }\end{array}$ \\
\hline $\begin{array}{l}\text { A konkrét web-shop } \rightarrow \\
\text { Elégedettség }\end{array}$ & 0,131 & $\underline{0,374 *}$ & $\underline{-0,005}$ & 0,363 \\
\hline PLS MGA p-érték & $\begin{array}{c}\text { Nincs } \\
\text { szignifikáns } \\
\text { különbség }\end{array}$ & E-term $(0,975)$ & Off-szolg $(0,975)$ & $\begin{array}{c}\text { Nincs } \\
\text { szignifikáns } \\
\text { különbség }\end{array}$ \\
\hline $\begin{array}{l}\text { Vásárlás lebony. } \rightarrow \\
\text { Elégedettség }\end{array}$ & $0,436^{* *}$ & 0,268 & $0,487 *$ & $-0,042$ \\
\hline PLS MGA p-érték & $\begin{array}{c}\text { Nincs } \\
\text { szignifikáns } \\
\text { különbség } \\
\end{array}$ & $\begin{array}{c}\text { Nincs } \\
\text { szignifikáns } \\
\text { különbség } \\
\end{array}$ & $\begin{array}{l}\text { Nincs szignifikáns } \\
\text { különbség }\end{array}$ & $\begin{array}{c}\text { Nincs } \\
\text { szignifikáns } \\
\text { különbség } \\
\end{array}$ \\
\hline $\begin{array}{l}\text { Elégedettség } \rightarrow \\
\text { Tradicionális WOM }\end{array}$ & $\underline{0,924 * * *}$ & $\underline{0,911 * * *}$ & $\underline{0,678 * * *}$ & $\underline{0,878 * * *}$ \\
\hline PLS MGA p-érték & E-termék $(0,999)$ & E-termék $(0,975)$ & $\begin{array}{c}\text { Off-termék }(0,999) \\
\text { Off-szolg }(0,975) \\
\text { E-szolg }(0,034)\end{array}$ & E-termék $(0,034)$ \\
\hline $\begin{array}{l}\text { Elégedettség } \rightarrow \\
\text { E-WOM hajlandóság }\end{array}$ & $0,310 * * *$ & $\underline{0,566 * * *}$ & $\underline{0,133 * * *}$ & $\mathbf{0 , 3 9 4 * * *}$ \\
\hline PLS MGA p-érték & $\begin{array}{c}\text { Nincs } \\
\text { szignifikáns } \\
\text { különbség }\end{array}$ & E-termék $(0,997)$ & Off-szolg $(0,997)$ & $\begin{array}{c}\text { Nincs } \\
\text { szignifikáns } \\
\text { különbség }\end{array}$ \\
\hline $\begin{array}{l}\text { Elégedettség } \rightarrow \\
\text { Újravásárlási szándék }\end{array}$ & $\underline{0,740 * * *}$ & $0,548 * * *$ & $\underline{0,383 * * *}$ & $0,637 * * *$ \\
\hline PLS MGA p-érték & E-termék $(0,979)$ & $\begin{array}{c}\text { Nincs } \\
\text { szignifikáns } \\
\text { különbség }\end{array}$ & Off-termék $(0,979)$ & $\begin{array}{c}\text { Nincs } \\
\text { szignifikáns } \\
\text { különbség }\end{array}$ \\
\hline
\end{tabular}

\section{3. táblázat: A függő változók magyarázott varianciája $\left(\mathbf{R}^{2}\right)$ közti különbségek a szegmensek között - biztonsággal és ügyfélszolgálattal kapcsolatban hiányos tapasztalattal rendelkezők}

Forrás: saját eredmények alapján saját szerkesztés

Az elégedettség és a hagyományos továbbajánlás közötti útegyüttható az e-termékek esetében a legalacsonyabb, mely szignifikánsan alacsonyabb az összes többi ekereskedelmi kategória értékénél. Ugyanennek a csoportnak szignifikánsan alacsonyabb az elégedettség és az e-WOM között útegyütthatója is, mint az offline-szolgáltatást vásárlók esetében. Az elégedettség és az újravásárlási szándék közötti együttható szintén szignifikánsan kisebb az e-terméket vásárlók esetében, mint a legerősebb úttal rendelkező offline-terméket vásárlóknál. Ezekben az esetekben az e-termékekhez tartozó magyarázott variancia is szignifikánsan alacsonyabb (53 - 54. táblázat) 


\begin{tabular}{|r|c|c|r|r|r|r|}
\hline & $\begin{array}{c}\text { p-érték } \\
\text { (E-szolg vs } \\
\text { E-term) }\end{array}$ & $\begin{array}{c}\text { p-érték } \\
\text { (E-szolg vs } \\
\text { Off-szolg) }\end{array}$ & $\begin{array}{c}\text { p-érték } \\
\text { (E-szolg vs } \\
\text { Off-term) }\end{array}$ & $\begin{array}{c}\text { p-érték } \\
\text { (E-term vs } \\
\text { Off-szolg) }\end{array}$ & $\begin{array}{c}\text { p-érték } \\
\text { (E-term vs } \\
\text { Off-term) }\end{array}$ & $\begin{array}{c}\text { p-érték } \\
\text { (Off-szolg vs } \\
\text { Off-term) }\end{array}$ \\
\hline $\mathbf{R}^{2}$ SAT & 0,573 & 0,293 & 0,404 & 0,892 & 0,934 & 0,923 \\
\hline $\mathbf{R}^{2}$ tr. WOM & 0,069 & 0,659 & 0,288 & 0,094 & 0,001 & 0,799 \\
\hline $\mathbf{R}^{2} \mathbf{E}$-WOM & 0,163 & 0,298 & 0,614 & 0,004 & 0,443 & 0,141 \\
\hline $\mathbf{R}^{2} \mathbf{B I}$ & 0,149 & 0,634 & 0,44 & 0,452 & 0,028 & 0,297 \\
\hline
\end{tabular}

54. táblázat: A függő változók magyarázott varianciája $\left(\mathbf{R}^{2}\right)$ közti különbségek a szegmensek között - biztonsággal és ügyfélszolgálattal kapcsolatban hiányos tapasztalattal rendelkezők

Forrás: saját eredmények alapján saját szerkesztés

Összességében tehát megállapíthatjuk, hogy az e-termékek modellje jelen csoportban minden egyes e-kereskedelmi kategóriától szignifikánsan különbözik, míg a többi kategória között nem figyelhető meg jelentős eltérés.

\subsection{A nagymintás, online kérdőíves kutatás összefoglalása}

Kutatásunk célja az volt, hogy megvizsgáljuk, hogy a szakirodalom alapján megkülönböztetett négy e-kereskedelmi szektorban a Francis és White (2004) által megalkotott e-szolgáltatásminőség dimenziók milyen kapcsolatban állnak az elégedettséggel, és feltárjuk, hogy az elégedettség és annak következményei közötti kapcsolatrendszer vajon eltérően alakul-e a négy szegmensben.

Elmézésünket tovább bonyolítja, hogy nem minden vásárló tudta az összes dimenziót értékelni, mert az ügyfélszolgálattal és/vagy a biztonsággal kapcsolatban többen is hiányos tapasztalattal rendelkeztek. Ezért a modellünk elemzése során meg kellett különböztetnünk négy esetet:

1. a teljes tapasztalattal rendelkezők,

2. az ügyfélszolgálattal kapcsolatban hiányos tapasztalattattal rendelkezők,

3. a biztonsággal kapcsolatban hiányos tapasztalattattal rendelkezők,

4. az ügyfélszolgálattal és a biztonsággal kapcsolatban hiányos tapasztalattattal rendelkezők.

Ahogy az 55. táblázat is mutatja, a különböző e-kereskedelmi kategóriák esetében a megnevezett négy e-szolgáltatásminőség dimenzió eltérő hatással bír az elégedettségre. Általánosságként megállapíthatjuk, hogy a konkrét webshopminőség, vagyis a tényleges honlap megjelenítése és designja nincs szignifikáns hatással az elégedettségre egyik kategóriában sem. Ezt magyarázhatja, hogy az e-kereskedelem egyre nagyobb 
elterjedtsége miatt a „bolt” esztétikai megjelenése már egyfajta alapelvárás, mintsem elégedettséget szignifikánsan befolyásoló tényező.

Az eredményeink is azt támasztják alá, hogy az egyéb funkciók, úgy mint a tényleges vásárlás lebonyolítása, a fizetés, az ügyfélszolgálat elérhetősége és a vele folytatott kommunikáció bírnak releváns hatással a különböző szegmensekben. Maga a vásárlási folyamat, illetve annak visszaigazolása és zökkenőmentessége az offline-termékek és szolgáltatások esetében releváns dimenzió, tehát azokban az esetekben, amikor a vásárlás megvalósítása offline is történhet, és több tapasztalata van már a vásárlóknak. Ennek egyik magyarázata az lehet, hogy az e-kereskedelmet ebben az esetben mint alternatív, kényelmesebb vásárlási megoldást használják az egyének, és az elégedettségükben ennek az előnynek a kihasználhatósága tükröződik leginkább.

Az e-termékek és -szolgáltatások esetében a biztonság dimenziója bír releváns hatással, ami nem meglepő, hisz a teljes folyamat, gyakran még a termékek elfogyasztása is az online világban történik, így sokkal jelentősebb a személyes adatok védelme és ennek hatása az elégedettségre. Megállapítható, hogy azokban az esetekben, amikor a vásárolt terméket, szolgáltatást nem tudjuk ténylegesen a „kezünkbe” fogni, nagyobb fontossággal bír a webshophoz köthető észlelt biztonság.

Az ügyfélszolgálat dimenziója az offline-termékek esetében releváns, vagyis akkor, amikor az internetes vásárlás után még hátra van a kiszállítási folyamat, tehát a webshop elhagyása után is nagyobb valószínűséggel merülhetnek fel különböző kérdések, esetleg problémák.

Kutatási mintánkban az ügyfélszolgálat az e-szolgáltatások esetében is releváns dimenziónak számít az elégedettség alakulása szempontjából. Ennek az lehet az oka, hogy a mintánkban túlnyomórészt e-banki vagy e-biztosítással kapcsolatos tranzakciókat értékeltek a megkérdezettek, vagyis olyan szolgáltatásokat, ahol az ügyfélszolgálattal való kommunikáció gyakran előfordulhat akár egyéb ügyek intézése miatt is. 


\begin{tabular}{|c|c|c|c|c|c|}
\hline & & $\begin{array}{l}\text { Útegyüttható } \\
\text { (Off-term) }\end{array}$ & $\begin{array}{l}\text { Útegyüttható } \\
\text { (Off-szolg) }\end{array}$ & $\begin{array}{l}\text { Útegyüttható } \\
\text { (E-term) }\end{array}$ & $\begin{array}{l}\text { Útegyüttható } \\
\text { (E-szolg) }\end{array}$ \\
\hline Teljes tapasztalat & \multirow{4}{*}{$\begin{array}{c}\text { Konkrét } \\
\text { webshop-minőség } \\
\rightarrow \text { Elégedettség }\end{array}$} & 0,063 & 0,051 & 0,006 & 0,149 \\
\hline $\begin{array}{l}\text { Nincs tapasztalat az } \\
\text { ügyfélszolgálattal }\end{array}$ & & 0,102 & 0,021 & 0,103 & $-0,018$ \\
\hline $\begin{array}{l}\text { Nincs tapasztalat a } \\
\text { biztonsággal }\end{array}$ & & 0,064 & N.A. & N.A. & $-0,064$ \\
\hline $\begin{array}{l}\text { Nincs tapasztalat az } \\
\text { ügyfélszolgálattal és a } \\
\text { biztonsággal }\end{array}$ & & 0,131 & $\mathbf{0 , 3 7 4 *}$ & $-0,005$ & 0,363 \\
\hline Teljes tapasztalat & \multirow{4}{*}{$\begin{array}{c}\text { Vásárlás } \\
\text { lebonyolításának } \\
\text { minősége } \rightarrow \\
\text { Elégedettség }\end{array}$} & $0,606 * * *$ & $0,417 *$ & 0,061 & 0,059 \\
\hline $\begin{array}{l}\text { Nincs tapasztalat az } \\
\text { ügyfélszolgálattal }\end{array}$ & & $0,575 * * *$ & 0,362 & $-0,242$ & 0,419 \\
\hline $\begin{array}{l}\text { Nincs tapasztalat a } \\
\text { biztonsággal }\end{array}$ & & $0,512 * *$ & N.A. & N.A. & 0,223 \\
\hline $\begin{array}{l}\text { Nincs tapasztalat az } \\
\text { ügyfélszolgálattal és a } \\
\text { biztonsággal }\end{array}$ & & $0,436 * *$ & 0,268 & $0,487 *$ & $-0,042$ \\
\hline Teljes tapasztalat & \multirow{4}{*}{$\begin{array}{l}\text { Biztonság } \rightarrow \\
\text { Elégedettség }\end{array}$} & $-0,129$ & 0,24 & $0,582 * * *$ & $0,282 *$ \\
\hline $\begin{array}{l}\text { Nincs tapasztalat az } \\
\text { ügyfélszolgálattal }\end{array}$ & & 0,165 & $0,442 *$ & $0,711 * * *$ & $0,418 *$ \\
\hline $\begin{array}{l}\text { Nincs tapasztalat a } \\
\text { biztonsággal }\end{array}$ & & $\begin{array}{c}\text { Nincs } \\
\text { tapasztalat }\end{array}$ & $\begin{array}{c}\text { Nincs } \\
\text { tapasztalat }\end{array}$ & $\begin{array}{c}\text { Nincs } \\
\text { tapasztalat }\end{array}$ & $\begin{array}{c}\text { Nincs } \\
\text { tapasztalat }\end{array}$ \\
\hline $\begin{array}{l}\text { Nincs tapasztalat az } \\
\text { ügyfélszolgálattal és a } \\
\text { biztonsággal }\end{array}$ & & $\begin{array}{c}\text { Nincs } \\
\text { tapasztalat }\end{array}$ & $\begin{array}{c}\text { Nincs } \\
\text { tapasztalat }\end{array}$ & $\begin{array}{c}\text { Nincs } \\
\text { tapasztalat }\end{array}$ & $\begin{array}{c}\text { Nincs } \\
\text { tapasztalat }\end{array}$ \\
\hline Teljes tapasztalat & \multirow{4}{*}{$\begin{array}{l}\text { Ügyfélszolgálat } \\
\text { minősége } \\
\rightarrow \text { Elégedettség }\end{array}$} & $0,407 * *$ & 0,25 & 0,122 & $0,448 * * *$ \\
\hline $\begin{array}{l}\text { Nincs tapasztalat az } \\
\text { ügyfélszolgálattal }\end{array}$ & & $\begin{array}{c}\text { Nincs } \\
\text { tapasztalat }\end{array}$ & $\begin{array}{c}\text { Nincs } \\
\text { tapasztalat }\end{array}$ & $\begin{array}{c}\text { Nincs } \\
\text { tapasztalat }\end{array}$ & $\begin{array}{c}\text { Nincs } \\
\text { tapasztalat }\end{array}$ \\
\hline $\begin{array}{l}\text { Nincs tapasztalat a } \\
\text { biztonsággal }\end{array}$ & & $0,372 *$ & $N . A$. & N.A. & $0,572 * *$ \\
\hline $\begin{array}{l}\text { Nincs tapasztalat az } \\
\text { ügyfélszolgálattal és a } \\
\text { biztonsággal }\end{array}$ & & $\begin{array}{c}\text { Nincs } \\
\text { tapasztalat }\end{array}$ & $\begin{array}{c}\text { Nincs } \\
\text { tapasztalat }\end{array}$ & $\begin{array}{c}\text { Nincs } \\
\text { tapasztalat }\end{array}$ & $\begin{array}{c}\text { Nincs } \\
\text { tapasztalat }\end{array}$ \\
\hline Teljes tapasztalat & \multirow{4}{*}{$\begin{array}{c}\text { Elégedettség } \rightarrow \\
\text { tradicionális } \\
\text { WOM } \\
\text { hajlandóság }\end{array}$} & $0,959 * * * 1$ & $0,901 * * *$ & $0,919 * * *$ & $0,846 * * *$ \\
\hline $\begin{array}{l}\text { Nincs tapasztalat az } \\
\text { ügyfélszolgálattal }\end{array}$ & & $0,749 * * *$ & $0,824 * * *$ & $0,899 * * *$ & $0,729 * * *$ \\
\hline $\begin{array}{l}\text { Nincs tapasztalat az } \\
\text { biztonsággal }\end{array}$ & & $0,890 * * * 1$ & N.A. & N.A. & $0,810 * * *$ \\
\hline $\begin{array}{l}\text { Nincs tapasztalat az } \\
\text { ügyfélszolgálattal és a } \\
\text { biztonsággal }\end{array}$ & & $0,924 * * *$ & $0,911 * * *$ & $0,678 * * *$ & $0,878 * * *$ \\
\hline Teljes tapasztalat & \multirow{4}{*}{$\begin{array}{c}\text { Elégedettség } \rightarrow \text { E- } \\
\text { WOM } \\
\text { hajlandóság }\end{array}$} & $0,708 * * * 1$ & $0,52 * * *$ & $0,678 * * *$ & $0,492 * * *$ \\
\hline $\begin{array}{l}\text { Nincs tapasztalat az } \\
\text { ügyfélszolgálattal }\end{array}$ & & $0,283 *$ & 0,218 & $0,280 * *$ & $0,408 * * * 1$ \\
\hline $\begin{array}{l}\text { Nincs tapasztalat a } \\
\text { biztonsággal }\end{array}$ & & $0,598 * * * 1$ & N.A. & N.A. & $0,507 * * *$ \\
\hline $\begin{array}{l}\text { Nincs tapasztalat az } \\
\text { ügyfélszolgálattal és a } \\
\text { biztonsággal }\end{array}$ & & $0,310 * * *$ & $0,566 * * *$ & $0,133 * * *$ & $0,394 * * *$ \\
\hline Teljes tapasztalat & \multirow{4}{*}{$\begin{array}{c}\text { Elégedettség } \rightarrow \\
\text { Újravásárlási } \\
\text { szándék }\end{array}$} & $0,879 * * * 1$ & $0,826 * * *$ & $0,799 * * *$ & $0,658 * * *$ \\
\hline $\begin{array}{l}\text { Nincs tapasztalat az } \\
\text { ügyfélszolgálattal }\end{array}$ & & $0,379 *$ & $0,537 *$ & $0,436 *$ & $0,594 * * * 1$ \\
\hline $\begin{array}{l}\text { Nincs tapasztalat a } \\
\text { biztonsággal }\end{array}$ & & $0,564 * * *$ & $N . A$. & $N . A$. & $0,557 * * * 1$ \\
\hline $\begin{array}{l}\text { Nincs tapasztalat az } \\
\text { ügyfélszolgálattal és a } \\
\text { biztonsággal }\end{array}$ & & $0,740 * * *$ & $0,548 * * *$ & $0,383 * * *$ & $0,637 * * *$ \\
\hline
\end{tabular}

\section{5. táblázat: Az e-szolgáltatásminőség dimenziók hatása az elégedettségre a} különböző e-kereskedelmi kategóriák esetében - Összefoglalás

Forrás: saját eredmények alapján saját szerkesztés 
Kutatásunk során azt is megvizsgáltuk, hogy a különböző e-szolgáltatásminőség dimenziókhoz tartozó útegyütthatók szignifikánsan eltérnek-e a vizsgált e-kereskedelmi kategóriákban, amely eredmények azonban nem túl sok plusz információt hordoznak, mivel a különböző esetekben eltérően alakultak a releváns dimenziók. Sokkal fontosabb és érdekesebb eredményeket hoz, amikor az összes szegmensben szignifikáns kapcsolatokat vesszük górcső alá, vagyis az elégedettség és annak következményei közötti utakat. Az eredményeink alapján megállapíthatjuk, hogy a vizsgált változók közötti hatások több esetben is szignifikánsan különböznek: a legtöbb különbség jellemezően az offline és online vonal között figyelhető meg.

\begin{tabular}{|c|c|c|c|c|c|}
\hline & & $\begin{array}{l}\text { Útegyüittható } \\
\text { (Off-term) }\end{array}$ & $\begin{array}{l}\text { Útegyüttható } \\
\text { (Off-szolg) }\end{array}$ & $\begin{array}{c}\text { Útegyüttható } \\
\text { (E-term) }\end{array}$ & $\begin{array}{c}\text { Útegyüittható } \\
\text { (E-szolg) }\end{array}$ \\
\hline Teljes tapasztalat & \multirow{4}{*}{ Elégedettség } & $74,3 \%$ & $70,6 \%$ & $48,2 \%$ & $71,4 \%$ \\
\hline $\begin{array}{l}\text { Nincs tapasztalat az } \\
\text { ügyfélszolgálattal }\end{array}$ & & $53,5 \%$ & $56,1 \%$ & $37,9 \%$ & $57,8 \%$ \\
\hline $\begin{array}{l}\text { Nincs tapasztalat a } \\
\text { biztonsággal }\end{array}$ & & $79,2 \%$ & N.A. & N.A. & $42,9 \%$ \\
\hline $\begin{array}{l}\text { Nincs tapasztalat az } \\
\text { ügyfélszolgálattal és a } \\
\text { biztonsággal }\end{array}$ & & $25,3 \%$ & $27,6 \%$ & $23,5 \%$ & $10,6 \%$ \\
\hline Teljes tapasztalat & \multirow{4}{*}{ tr. WOM } & $92,0 \%$ & $81,2 \%$ & $84,4 \%$ & $71,6 \%$ \\
\hline $\begin{array}{l}\text { Nincs tapasztalat az } \\
\text { ügyfélszolgálattal }\end{array}$ & & $55,3 \%$ & $67,8 \%$ & $80,4 \%$ & $53,2 \%$ \\
\hline $\begin{array}{l}\text { Nincs tapasztalat a } \\
\text { biztonsággal }\end{array}$ & & $79,2 \%$ & N.A. & N.A. & $65,6 \%$ \\
\hline $\begin{array}{l}\text { Nincs tapasztalat az } \\
\text { ügyfélszolgálattal és a } \\
\text { biztonsággal }\end{array}$ & & $85,3 \%$ & $83,0 \%$ & $45,9 \%$ & $77,0 \%$ \\
\hline Teljes tapasztalat & \multirow{4}{*}{ e-WOM } & $50,1 \%$ & $27,0 \%$ & $45,9 \%$ & $24,2 \%$ \\
\hline $\begin{array}{l}\text { Nincs tapasztalat az } \\
\text { ügyfélszolgálattal } \\
\end{array}$ & & $6,2 \%$ & $4,8 \%$ & $6,4 \%$ & $16,7 \%$ \\
\hline $\begin{array}{l}\text { Nincs tapasztalat a } \\
\text { biztonsággal }\end{array}$ & & $35,7 \%$ & N.A. & N.A. & $25,7 \%$ \\
\hline $\begin{array}{l}\text { Nincs tapasztalat az } \\
\text { ügyfélszolgálattal és a } \\
\text { biztonsággal }\end{array}$ & & $9,6 \%$ & $32,0 \%$ & $1,8 \%$ & $15,5 \%$ \\
\hline Teljes tapasztalat & \multirow{4}{*}{$\begin{array}{l}\text { Újjravásárlási } \\
\text { szándék }\end{array}$} & $77,3 \%$ & $68,2 \%$ & $63,9 \%$ & $43,3 \%$ \\
\hline $\begin{array}{l}\text { Nincs tapasztalat az } \\
\text { ügyfélszolgálattal } \\
\end{array}$ & & $12,7 \%$ & $28,9 \%$ & $17,6 \%$ & $35,3 \%$ \\
\hline $\begin{array}{l}\text { Nincs tapasztalat a } \\
\text { biztonsággal }\end{array}$ & & $31,9 \%$ & N.A. & N.A. & $31,0 \%$ \\
\hline $\begin{array}{l}\text { Nincs tapasztalat az } \\
\text { ügyfélszolgálattal és a } \\
\text { biztonsággal }\end{array}$ & & $54,7 \%$ & $30,1 \%$ & $14,6 \%$ & $40,6 \%$ \\
\hline
\end{tabular}

56. táblázat: Az elégedettség hatása a hagyományos és e-továbbajánlási szándékra valamint az újravásárlási hajlandóságra a különböző e-kereskedelmi kategóriák esetében - Összefoglalás

Forrás: saját eredmények alapján saját szerkesztés

A kutatásunk középpontjában álló, vagyis a teljes tapasztalattal rendelkező válaszadók esetében általánosságban megállapítható, hogy a termékekhez kapcsoló továbbajánlási szándék mindig magasabb. Az offline és az online szállítási módok közül is mindig az offline esetében magasabb az érték. Szignifikáns különbség azonban csak a két szélsőérték (offline-termékek, e-szolgáltatások) esetében figyelhető meg. Ezzel szemben 
az elégedettség és az újravásárlási szándék közötti útegyüttható offline esetben magasabb, tehát az elégedettségi szint hatása az újravásárlási szándékra az online jószágok esetében kisebb.

Az eredmények a további három tapasztalati kategória esetében ettől eltérően alakulnak, azonban mivel ezekben a szegmensekben további kutatások szükségesek az eredmények elfogadásához, a jelen munka keretében nem szeretnénk őket részletesen elemezni, és egyfajta kutatási irányként jelöljük meg a további kategóriák vizsgálatát.

Az endogén változók magyarázott varianciáit megvizsgálva láthatjuk, hogy a különböző szegmensek esetében eltérően alakul mértékük, így bizonyos szegmensekben további magyarázó változók feltárása szükséges. Ami egyértelműen látszik az eredményeinkből, az az, hogy az ügyfélszolgálat minősítése jelentős közvetett hatással bírhat az elektronikus WOM-ra, tehát az elégedettség a két változó között mediáló hatással bír, mivel az ügyfélszolgálat hiányos értékelése esetében az e-WOM magyarázott varianciája jelentősen elmarad a többi esetben megfigyelhetőtől (56. táblázat).

\subsection{Az elégedettség alakulása offline- és elektronikus-termék vásárlása esetében: Kísérleti kutatás}

A nagymintás kutatásunk eredményeinek mélyebb megértése céljából egy kísérletet is megterveztünk. Célunk megvizsgálni, hogy ugyanazt a webshopot felhasználva milyen értékelések születnek két különböző terméktípus - egy offline-termék (ruházati kiegészítő) és egy e-termék (e-könyv) - vásárlása során, hogy a feltárt különbségek vajon ebben az esetben is léteznek-e, illetve a minőségészlelést és az értékelések miértjét szeretnénk minél mélyebben megérteni. A kísérlet levezetését sajnos túl bonyolulttá tette volna, ha mind a négy kategóriát vizsgáljuk, ezért döntöttünk a két szegmensre történő korlátozás mellett.

Kísérletünk fő motivációja tehát, hogy egy jószágtípuson belül megértsük az offline és az elektronikus szállítású és „fogyasztású” termékek közti különbségeket és az ezek mögött meghúzódó okokat. Ennek utólagos mérésére azért volt szükség, mert a nagymintás megkérdezés során a válaszadóink különböző honlapokat értékeltek, így a feltárt különbségek adódhatnak a használt honlap sajátosságaiból is, nem feltétlenül az ekereskedelmi kategóriák közti különbségekböl. Emellett az eredményeket az is befolyásolhatta, hogy a megkérdezettek tapasztalata eltérő az értékelt webshophoz 
köthető vásárlásról: nem tudjuk megkülönbözetni az első vásárlókat az újravásárlóktól. Ennek megfelelően egy saját, fiktív webshopot használtunk a kutatásunkban, amelyet két szcenárióra felosztva az első vásárlók és az újravásárlók (A és B szcenárió) közötti különbségeket is mérni tudtuk.

Kutatásunk során azért az offline-termékek és e-termékek kategóriát választottuk, mert a nagymintás kutatás alapján az offline-termékek sok esetben szignifikánsan különböznek az online jószágoktól. Igaz, hogy a legnagyobb különbségek az offline-termékek és eszolgáltatások között figyelhetők meg, de az azonos jószágtípus alkalmazása melletti érv, hogy a nagymintás és a korábbi kutatásaink ${ }^{15}$ alapján láthattuk, a termékek és szolgáltatások között is megfigyelhetőek különbségek, amelyeket ez esetben szerettünk volna figyelmen kívül hagyni. Kísérletünk eredményváltozója tehát az elégedettség és annak következményei, míg magyarázóváltozóként az e-vásárlás minősége számított. A vásárlás feltételei és kimenetelei minden esetben azonosak voltak, csak a vásárolt termékek sorrendje különbözött, tehát ezt tekinthetjük kontrollváltozónak.

Kísérletünk során a legnagyobb hazai webshop kínálatára építve hoztuk létre a Csak egy kattintás webshopot (http://csakegykattintas.shoprenter.hu/), melyröl részletes képeket a 9. számú melléklet tartalmaz. A webshopban kapható termékeket 6 fő kategóriába soroltuk (élelmiszer, játékok, könyvek, ruházat, szépségápolás, újdonságok), mindegyiket széles kínálattal töltöttük fel, azonban a kísérlet során mindössze két kategória volt releváns a résztvevőknek. A kísérletben a Budapesti Corvinus Egyetem alap- és mesterszakos hallgatói vettek részt, összesen 100 fö, két szcenárióba sorolva (5050 fó).

Mindét szcenárióban ugyanazt a két vásárlást kellett megvalósítani a résztvevőknek, csak eltérő sorrendben: az A szcenárióban résztvevők először offline-terméket, majd eterméket vásároltak, míg a $\mathrm{B}$ szcenárióban fordítva. A vásárlások maximalizált értékét a GKI Digital legfrissebb (2014) kutatása alapján határoztuk meg: saját részre történő ruházati kiegészítő vásárlása esetében maximum 8.300 Ft, míg barát részére történő ekönyv vásárlása esetében $2.700 \mathrm{Ft}$ összegben (http://www.gkidigital.hu/wpcontent/uploads/2014/10/GKI-Digital_IG_eker_2014.jpg). Az offline-termékek közül azért a ruházati kiegészítőt választottuk, mert az Eurostat (2014) eredményei alapján ez a

${ }^{15}$ Részletek a 10. mellékletben. 
legnépszerübb offline-termék-kategória hazánkban, míg az e-könyv a legnépszerübb online. A kísérlet részletes leírását a a 10. szánú melléklet tartalmazza.

A webshopban a vásárlók összesen 158 e-könyv közül választhattak (akár többet is a megjelölt összeghatárig), illetve 172 darab ruházati kiegészítő és táska közül, amelyek közül 106 darab felelt meg a 8.300 Ft-os maximalizált árnak.

A kutatásban részt vevő hallgatók az instrukciókat e-mailen kapták meg, illetve a vásárlás teljesülése után a letöltött e-könyvből. A ruházati kiegészítő esetében a házhozszállítást, valamint az utánvételes fizetést kellett választani, és egy olyan esetet kellett értékelni, amelyben a megrendelt terméket épségben, 10 nap múlva megkapta a megrendelő. Az ekönyv esetében szállítási módként az online letöltést, fizetési módként pedig a banki átutalást választották a résztvevők. A rendelés leadása és az átutalás „teljesülése” után, mely megközelítőleg 5 percet vett igényben, már elérhető volt a letöltendő dokumentum.

\subsubsection{A résztvevők}

A kísérletet 2014 decemberében valósítottuk meg. 50 fö vett részt az A és 50 fö a B szcenárióban. A kísérletben résztvevők többsége mindkét esetben nő volt (57. táblázat), ami annak is betudható, hogy a kiválasztott szakokon tanuló hallgatók többsége is nő. A legfiatalabb résztvevő 18 éves, a legidősebb 32, és a résztvevők átlagos életkora mindkét szcenárióban 23 év.

\begin{tabular}{|c|c|c|c|}
\hline & A szcenárió & B szcenárió & Teljes \\
\hline \multicolumn{4}{|l|}{ Nem } \\
\hline Férfi & 16 & 15 & 31 \\
\hline Nö & 34 & 35 & 69 \\
\hline \multicolumn{4}{|l|}{ Kor } \\
\hline 32 év & 1 & 0 & 1 \\
\hline 26 év & 1 & 1 & 2 \\
\hline 25 év & 2 & 2 & 4 \\
\hline 24 év & 3 & 7 & 10 \\
\hline 23 év & 19 & 8 & 27 \\
\hline 22 év & 5 & 6 & 11 \\
\hline 21 év & 12 & 12 & 24 \\
\hline 20 év & 6 & 12 & 18 \\
\hline 19 év & 0 & 1 & 1 \\
\hline 18 év & 1 & 1 & 2 \\
\hline \multirow[t]{2}{*}{ Átlag } & 23 & 23 & 23 \\
\hline & 50 & 50 & 100 \\
\hline
\end{tabular}

57. táblázat: A kísérletben résztvevők demográfiai jellemzői ( $\mathrm{N}=\mathbf{1 0 0}$ fó)

Forrás: az eredmények alapján saját szerkesztés 
A résztvevőket a vásárlások megkezdése előtt megkértük, hogy jellemezzék online vásárlási szokásaikat annak gyakorisága és a vásárolt termékek és szolgáltatások alapján. A résztvevők közül mindenki vásárolt már online, és voltak közöttük aktív, vagyis sürübben, mint havonta vásárlók (összesen 23 fö), illetve kicsit „passzívabb”, általában négyhavonta vásárlók (16 fö) (58. táblázat). A résztvevők körében az elmúlt három hónap során online vásárolt legnépszerübb termékek és szolgáltatások a belépőjegyek (58fó), az utazás/szállás (42 fö), a ruházat (35 fö), valamint a meleg étel (34 fö) (59. táblázat).

\begin{tabular}{|l|c|c|c|}
\hline & A szcenárió & Szcenárió & Teljes \\
\hline Hetente többször & 0 & 3 & 3 \\
\hline Hetente egyszer & 2 & 2 & 4 \\
\hline Kéthetente & 7 & 8 & 15 \\
\hline Havonta & 11 & 15 & 26 \\
\hline Kéthavonta & 22 & 14 & 36 \\
\hline Négyhavonta & 8 & 8 & 16 \\
\hline $\begin{array}{l}\text { Ritkábban, mint } \\
\text { négyhavonta }\end{array}$ & 0 & 0 & 0 \\
\hline N (fö) & 50 & 50 & 100 \\
\hline
\end{tabular}

58. táblázat: A kísérletben résztvevők e-vásárlási szokásai ( $\mathbf{N}=\mathbf{1 0 0}$ fö)

Forrás: az eredmények alapján saját szerkesztés

\begin{tabular}{|l|c|c|c|}
\hline & $\begin{array}{c}\text { A szcenárió } \\
\text { (említés) }\end{array}$ & $\begin{array}{c}\text { B szcenárió } \\
\text { (említés) }\end{array}$ & Teljes \\
\hline Mozi-, színházjegy vagy egyéb belépö & 31 & 27 & 58 \\
\hline Utazás, szállás, repülőjegy & 18 & 24 & 42 \\
\hline Ruházat, sporteszközök, ékszer & 17 & 18 & 35 \\
\hline Meleg étel & 19 & 15 & 34 \\
\hline Szórakoztató elektronika, müszaki cikkek & 14 & 10 & 24 \\
\hline Könyv, újság vagy magazin & 15 & 9 & 24 \\
\hline Számítástechnikai eszköz & 10 & 8 & 18 \\
\hline $\begin{array}{l}\text { Valamilyen fizetős szolgáltatói felületen történő } \\
\text { regisztráció (pl. e-banking, randioldal, online tv stb.) }\end{array}$ & 4 & 13 & 17 \\
\hline Szoftver vagy valamilyen applikáció & 8 & 5 & 13 \\
\hline Kozmetikumok & 3 & 7 & 10 \\
\hline Élelmiszer & 5 & 4 & 9 \\
\hline $\begin{array}{l}\text { Biztosításkötés kizárólag az online felületet felhasználva } \\
\text { (pl. alkusz, biztosítói felületet) }\end{array}$ & 4 & 5 & 9 \\
\hline Háztartási berendezés & 1 & 6 & 7 \\
\hline E-könyv, e-újság vagy e-magazin & 2 & 5 & 7 \\
\hline Film-, zeneletöltés pénzért & 3 & 3 & 6 \\
\hline Film, zene, videójáték CD-n, DVD-n & 2 & 3 & 5 \\
\hline Online tözsde, részvényvásárlás & 3 & 1 & 4 \\
\hline Valamilyen fizetös online kurzusra történő regisztráció & 1 & 3 & 4 \\
\hline Letölthető videojáték & 0 & 0 & 0 \\
\hline Egyéb & 5 & 2 & 7 \\
\hline
\end{tabular}

59. táblázat: A kísérletben résztvevők e-vásárlási szokásai: az elmúlt három

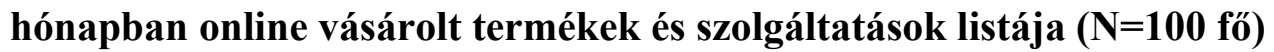

Forrás: az eredmények alapján saját szerkesztés 
A konkrét, irányított vásárlási folyamat után a résztvevőket megkértük, hogy írjanak véleményt a megvalósult vásárlással kapcsolatban, melyet szívesen közzétennének online a webshop értékelő felületén. Ezután egy rövid kérdőív segítségével kellett értékelniük a webshopban megvalósult vásárlás összegzett (e-szolgáltatás) minőségét, illetve további manifeszt változókkal elégedettségüket, újravásárlási, hagyományos és e-továbbajánlási szándékukat is mértük a nagymintás kutatásban is felhasznált validált skálák segítségével. Az e-szolgáltatásminőség releváns dimenzióit az egyszerüség kedvéért mértünk egy összegző kérdéssel, melynél részletesen elmagyaráztuk, milyen faktorokat vegyenek figyelembe az értékeléskor. A kísérlet egyik korlátja, hogy a fizetést csak szimulálni tudtuk $^{16}$. A kérdőív kitöltése után kapták meg a résztvevők az instrukciókat a második vásárlási szituációhoz, amelynek végrehajtása után ismét egy kérdőívet kellett kitölteniük.

\begin{tabular}{|c|c|c|c|c|c|c|}
\hline & & \multicolumn{2}{|c|}{ A szcenárió } & \multicolumn{2}{|c|}{ B szcenárió } & \multirow[b]{2}{*}{ Teljes } \\
\hline & & $\begin{array}{l}\text { Offline- } \\
\text { termék }\end{array}$ & $\begin{array}{c}\text { E- } \\
\text { termék }\end{array}$ & $\begin{array}{l}\text { Offline- } \\
\text { termék }\end{array}$ & $\begin{array}{c}\text { E- } \\
\text { termék }\end{array}$ & \\
\hline \multirow{2}{*}{$\begin{array}{l}\text { A webshophoz kapcsolódó teljes } \\
\text { minőségészlelés (webshop design, } \\
\text { megbízhatóság, szállítás) a vásárlás során }\end{array}$} & Átlag & 5,20 & 5,58 & 5,20 & 5,82 & 5,45 \\
\hline & Szórás & 1,11 & 1,30 & 1,25 & 1,02 & 1,19 \\
\hline \multirow{2}{*}{$\begin{array}{l}\text { Jó döntés volt a kiválasztott ruházati } \\
\text { kiegészítőt ezen az oldalon vásárolni. }\end{array}$} & Átlag & 4,36 & 5,28 & 3,96 & 5,88 & 4,87 \\
\hline & Szórás & 1,76 & 1,75 & 1,78 & 1,17 & 1,79 \\
\hline \multirow{2}{*}{$\begin{array}{l}\text { Ha újra ruházati kiegészítőt kellene } \\
\text { vásárolnom ebben a webshopban, } \\
\text { valószínüleg ugyanúgy értékelném a céget. }\end{array}$} & Átlag & 5,46 & 5,80 & 4,70 & 6,02 & 5,50 \\
\hline & Szórás & 1,45 & 1,58 & 1,92 & 1,12 & 1,61 \\
\hline \multirow{2}{*}{$\begin{array}{l}\text { Elégedett vagyok a döntésemmel, hogy } \\
\text { ezen az oldalon vásároltam. }\end{array}$} & Átlag & 4,48 & 5,26 & 4,16 & 5,90 & 4,95 \\
\hline & Szórás & 1,74 & 1,65 & 1,75 & 1,05 & 1,71 \\
\hline \multirow{2}{*}{ Elégedettség ÁTLAG } & Átlag & 4,77 & 5,45 & 4,27 & 5,93 & 5,11 \\
\hline & Szórás & 1,32 & 1,45 & 1,47 & 0,97 & 1,46 \\
\hline \multirow{2}{*}{$\begin{array}{l}\text { Pozitív dolgokat mondanék másoknak } \\
\text { erről a webáruházról a ruházati kiegészítő } \\
\text { vásárlásával kapcsolatban. }\end{array}$} & Átlag & 4,38 & 4,88 & 4,14 & 5,88 & 4,82 \\
\hline & Szórás & 1,79 & 1,79 & 1,78 & 1,00 & 1,75 \\
\hline \multirow{2}{*}{$\begin{array}{l}\text { Hasonló termék vásárlására ajánlanám a } \\
\text { webáruházat azoknak, akik kíváncsiak a } \\
\text { tanácsomra. }\end{array}$} & Átlag & 4,02 & 4,68 & 3,76 & 5,46 & 4,48 \\
\hline & Szórás & 1,88 & 1,93 & 1,84 & 1,20 & 1,85 \\
\hline \multirow{2}{*}{$\begin{array}{l}\text { Bátorítanám a barátaimat és rokonaimat, } \\
\text { hogy használják ezt a webáruházat hasonló } \\
\text { termék vásárlására. }\end{array}$} & Átlag & 4,08 & 4,44 & 3,64 & 5,20 & 4,34 \\
\hline & Szórás & 1,77 & 2,05 & 1,85 & 1,18 & 1,82 \\
\hline \multirow{2}{*}{ WOM ÁTLAG } & Átlag & 3,98 & 4,54 & 3,65 & 5,23 & 4,35 \\
\hline & Szórás & 1,71 & 1,85 & 1,63 & 1,02 & 1,68 \\
\hline \multirow{2}{*}{$\begin{array}{l}\text { A webshopról szívesen osztanék meg } \\
\text { pozitív véleményt az interneten. }\end{array}$} & Átlag & 3,64 & 4,00 & 3,68 & 4,42 & 3,94 \\
\hline & Szórás & 1,87 & 1,80 & 1,58 & 1,46 & 1,70 \\
\hline \multirow{2}{*}{$\begin{array}{l}\text { Szándékozom a közeljövőben hasonló } \\
\text { terméket vásárolni erről az oldalról. }\end{array}$} & Átlag & 3,44 & 4,14 & 3,04 & 4,38 & 3,75 \\
\hline & Szórás & 2,00 & 1,99 & 1,56 & 1,43 & 1,83 \\
\hline
\end{tabular}

\section{0. táblázat: A megvalósított vásárlások értékelése ( $\mathbf{N}=\mathbf{1 0 0}$ fö)}

Forrás: az eredmények alapján saját szerkesztés

\footnotetext{
${ }^{16}$ Szimuláció alatt azt értjük, hogy leírtuk nekik, mi történt.
} 


\subsubsection{A megvalósult vásárlások értékelése}

Az eredmények alapján megállapítható, hogy az offline-termékek vásárlásának értékeléséhez alacsonyabb átlagok tartoznak, melyek a legtöbb esetben szignifikánsan eltérnek az e-termékek vásárlásának értékelésétől. Ebben, ahogy majd a szöveges értékelések elemzésénél is látni fogjuk, nem csak a hosszú szállítási időnek volt jelentősége.

\begin{tabular}{|c|c|c|c|c|c|}
\hline & & $\begin{array}{l}\text { A szcenárió } \\
\text { (1-2. vásárlás) }\end{array}$ & $\begin{array}{l}\text { B szcenárió } \\
\text { (1-2. vásárlás) }\end{array}$ & $\begin{array}{l}\text { Különbség } \\
\text { A-B szcenárió }\end{array}$ & Teljes \\
\hline \multirow{3}{*}{ Qual } & $\begin{array}{c}\text { A második vásárlás értékelése } \\
\text { negatívabb (fö) }\end{array}$ & 26 & 24 & 2 & 50 \\
\hline & $\begin{array}{c}\text { A második vásárlás értékelése } \\
\text { ugyanolyan (fô) }\end{array}$ & 12 & 16 & -4 & 28 \\
\hline & $\begin{array}{c}\text { A második vásárlás értékelése } \\
\text { pozitívabb (fö) }\end{array}$ & 12 & 10 & 2 & 22 \\
\hline \multirow{3}{*}{ SAT } & $\begin{array}{c}\text { A második vásárlás értékelése } \\
\text { negatívabb (fö) }\end{array}$ & 36 & 41 & -5 & 77 \\
\hline & $\begin{array}{c}\text { a második vásárlás értékelése } \\
\text { ugyanolyan (fö) }\end{array}$ & 6 & 3 & 3 & 9 \\
\hline & $\begin{array}{c}\text { a második vásárlás értékelése } \\
\text { pozitívabb (fö) }\end{array}$ & 8 & 6 & 2 & 14 \\
\hline \multirow{3}{*}{ WOM } & $\begin{array}{c}\text { A második vásárlás értékelése } \\
\text { negatívabb (fô) }\end{array}$ & 32 & 40 & -8 & 72 \\
\hline & $\begin{array}{c}\text { A második vásárlás értékelése } \\
\text { ugyanolyan (fö) }\end{array}$ & 2 & 2 & 0 & 4 \\
\hline & $\begin{array}{c}\text { A második vásárlás értékelése } \\
\text { pozitívabb (fö) }\end{array}$ & 16 & 8 & 8 & 24 \\
\hline \multirow{3}{*}{ EWOM } & $\begin{array}{c}\text { A második vásárlás értékelése } \\
\text { negatívabb (fô) }\end{array}$ & 22 & 23 & -1 & 45 \\
\hline & $\begin{array}{c}\text { A második vásárlás értékelése } \\
\text { ugyanolyan (fö) }\end{array}$ & 19 & 17 & 2 & 36 \\
\hline & $\begin{array}{c}\text { A második vásárlás értékelése } \\
\text { pozitívabb (fö) }\end{array}$ & 9 & 10 & -1 & 19 \\
\hline \multirow{3}{*}{ BI } & $\begin{array}{c}\text { A második vásárlás értékelése } \\
\text { negatívabb (fö) }\end{array}$ & 26 & 37 & -11 & 63 \\
\hline & $\begin{array}{c}\text { A második vásárlás értékelése } \\
\text { ugyanolyan (fö) }\end{array}$ & 8 & 9 & -1 & 17 \\
\hline & $\begin{array}{c}\text { A második vásárlás értékelése } \\
\text { pozitívabb (fö) }\end{array}$ & 16 & 4 & 12 & 20 \\
\hline
\end{tabular}

\section{1. táblázat: Az első és újravásárlások átlagai közti különbségek ( $\mathbf{N = 1 0 0 ~ f o ̋ ) ~}$}

Forrás: az eredmények alapján saját szerkesztés

A két szcenárió között szignifikáns különbség az offline-termékek értékelése során mindössze egy manifeszt változó esetében figyelhető meg (SAT_2). Ebben az esetben a B szcenárióban résztvevők értékelése szignifikánsan alacsonyabb, tehát azoké, akik az offline-terméket másodszor, egy újravásárlás során vették meg. Az elemzés alapján az is megállapítható, hogy a B szcenárió esetében, ahol a rosszabb szállítási feltételekkel biztosított vásárlás az újrahasználat során valósult meg, gyengébb eredményekkel 
találkozhatunk az offline-termékek vásárlásának értékelése során, habár az e-termékek vásárlásának átlagos értékelése az A szcenárióénál magasabb: az e-termékek vásárlásához köthető értékelések több esetben szignifikánsan eltérnek egymástól (a táblázatban sötétszürke jelöléssel), és minden esetben a $\mathrm{B}$ szcenárióban résztvevők értékelése a jobb.

\begin{tabular}{|c|c|c|c|c|c|}
\hline & & $\mathbf{N}$ & $\begin{array}{c}\text { Átlag } \\
\text { (1-2. vásárlás értékelése) }\end{array}$ & Szórás & $\begin{array}{l}\text { F-próba } \\
\text { (szaig) }\end{array}$ \\
\hline \multirow{3}{*}{$\begin{array}{l}\text { Qual_overall_ } \\
\text { delta }\end{array}$} & A szcenárió & 50 &,- 380 & 1,469 & \multirow{3}{*}{,439 } \\
\hline & B szcenárió & 50 &,- 620 & 1,615 & \\
\hline & Teljes & 100 &,- 500 & 1,541 & \\
\hline \multirow{3}{*}{ SAT_1_delta } & A szcenárió & 50 &,- 920 & 2,284 & \multirow{3}{*}{,018 } \\
\hline & B szcenárió & 50 & $-1,920$ & 1,850 & \\
\hline & Teljes & 100 & $-1,420$ & 2,128 & \\
\hline \multirow{3}{*}{ SAT_2_delta } & A szcenárió & 50 &,- 340 & 1,975 & \multirow{3}{*}{,015 } \\
\hline & B szcenárió & 50 & $-1,320$ & 1,994 & \\
\hline & Teljes & 100 &,- 830 & 2,035 & \\
\hline \multirow{3}{*}{ SAT_3_delta } & A szcenárió & 50 &,- 780 & 2,053 & \multirow{3}{*}{, 016} \\
\hline & B szcenárió & 50 & $-1,740$ & 1,838 & \\
\hline & Teljes & 100 & $-1,260$ & 1,998 & \\
\hline \multirow{3}{*}{ WOM_1_delta } & A szcenárió & 50 &,- 500 & 2,288 & \multirow{3}{*}{, 003} \\
\hline & B szcenárió & 50 & $-1,740$ & 1,771 & \\
\hline & Teljes & 100 & $-1,120$ & 2,129 & \\
\hline \multirow{3}{*}{ WOM_2_delta } & A szcenárió & 50 & -660 & 2,210 & \multirow{3}{*}{, 013} \\
\hline & B szcenárió & 50 & $-1,700$ & 1,887 & \\
\hline & Teljes & 100 & $-1,180$ & 2,110 & \\
\hline \multirow{3}{*}{ WOM_3_delta } & A szcenárió & 50 &,- 360 & 2,363 & \multirow{3}{*}{, 005} \\
\hline & B szcenárió & 50 & $-1,560$ & 1,786 & \\
\hline & Teljes & 100 &,- 960 & 2,169 & \\
\hline \multirow{3}{*}{$\begin{array}{l}\text { EWOM_1_del } \\
\text { ta }\end{array}$} & A szcenárió & 50 &,- 360 & 1,711 & \multirow{3}{*}{, 261} \\
\hline & B szcenárió & 50 &,- 740 & 1,651 & \\
\hline & Teljes & 100 &,- 550 & 1,684 & \\
\hline \multirow{3}{*}{ BI_1_delta } & A szcenárió & 50 &,- 700 & 2,215 & \multirow{3}{*}{,096 } \\
\hline & B szcenárió & 50 & $-1,340$ & 1,533 & \\
\hline & Teljes & 100 & $-1,020$ & 1,923 & \\
\hline
\end{tabular}

\section{2. táblázat: Az első és az újravásárlások átlagai közötti különbségek értékelése a két szcenárió esetében ( $\mathrm{N}=100$ fö)}

Forrás: az eredmények alapján saját szerkesztés

Összefoglalva az A szcenárióban, amikor is először valósult meg a „gyengébb” vásárlás, sokkal kisebb különbségek figyelhetőek meg az offline-termékek és az e-termékek vásárlásának értékelésében, mint a $\mathrm{B}$ esetben. Ezek alapján megállapíthatjuk, hogy ha egy elégedettséggel záródó vásárlást egy kevésbé jó minőségü követ, akkor, mivel az elvárt minőségszint magasabb, rosszabb értékelésekkel, vagyis nagyobb különbségekkel találkozhatunk, mint ellenkező esetben. Ezt az a tény is alátámasztja, hogy az újravásárlást gyengébben értékelők száma a B szcenárió esetében a minőség kivételével mindig alacsonyabb (60. táblázat). Az első és második (kvázi az újra-) vásárlás értékelése közötti különbségek az elégedettség és a hagyományos továbbajánlási szándék esetében 
szignifikánsan különböznek: minden esetben a B szcenárióban fellelhető átlagos különbségek a nagyobbak. Ilyen irányú különbség a többi esetről is elmondható, ezeknél azonban az F-próba alapján a szignifikáns eltérést el kell utasítanunk. (61 -62. táblázat)

\subsubsection{A vásárláshoz kapcsolódó vélemények értékelése}

Kísérletünk során a résztvevőket a vásárlás tényleges, számokban történő értékelése előtt megkértük, hogy írjanak egy értékelést az adott vásárlásáról, melyet az interneten szívesen közzétennének. Ennek köszönhetően minden egyes vásárlásról 50 darab, kvalitatív jellegü információ is a rendelkezésünkre állt, melyek a vásárlások értékelésének mélyebb megértését támogatják.

\begin{tabular}{|l|c|l|c|}
\hline Pozitív említés (OT) & Db & Pozitív említés (OT) & Db \\
\hline egyszerú vásárlás & 28 & biztonságos & 1 \\
\hline gyors vásárlás & 15 & egyszerü felület & 1 \\
\hline választék nagy & 9 & leírás jobb, mint az e-könyvnél & 1 \\
\hline könnyen kezelhetö & 8 & gyors regisztráció & 1 \\
\hline szállítás & 8 & információk & 1 \\
\hline akciók & 7 & sok kép & 1 \\
\hline könnyü keresés & 5 & jó használat & 1 \\
\hline kényelmes vásárlás & 5 & szép képek & 1 \\
\hline termék épségben & 5 & megéri & 1 \\
\hline átlátható & 5 & gyors kiszállítás & 1 \\
\hline áttekinthetö & 4 & jó kategóriák & 1 \\
\hline kategorizálás & 4 & ajánlat & 1 \\
\hline könnyü tájékozódni & 4 & jó termékek & 1 \\
\hline megbízható & 3 & sok instrukció & 1 \\
\hline könnyü navigáció & 3 & jól átlátható & 1 \\
\hline regisztráció nélküli vásárlás & 3 & sorba rendezés & 1 \\
\hline könnyü használat & 3 & raktári mennyiség látszik & 1 \\
\hline vásárlás rendben & 3 & széles választék árkategóriát tekintve & 1 \\
\hline ugyanaz a termék, mint a képen & 2 & ár szerinti rendezés & 1 \\
\hline letisztult & 2 & táskák kategorizálása rendben & 1 \\
\hline regisztráció egyszerü & 2 & áttekinthetö & 1 \\
\hline elégedett & 2 & top termék rész & 1 \\
\hline árak & 2 & rendben megérkezett & 1 \\
\hline nagy választék & 2 & válaszék nagy & 1 \\
\hline design & 2 & rendezés & 1 \\
\hline férfi-nö külön részletezve & 2 & választott termék jó & 1 \\
\hline minden rendben & 2 & részletes instrukciók & 172 \\
\hline problémamentes vásárlás & 1 & ruházat online új élmény & 1 \\
\hline sok fizetési és szállítási mód & Összesen & 1 \\
\hline & & & 1 \\
\hline & & 1 \\
\hline
\end{tabular}

\section{3. táblázat: Az offline-termék vásárlásához köthető véleményekben megjelent pozitív értékek ( $\mathrm{N}=100$ komment)}

Forrás: az eredmények alapján saját szerkesztés

A mélyreható megismerés céljából először a tartalomelemzés módszerével vizsgáltuk meg a kommenteket. Az elemzés során minden egyes kommentet megvizsgáltunk az 
alapján, hogy hány negatív és hány pozitív tulajdonságot tartalmaz a vásárlással kapcsolatban, és ezek milyen témaköröket érintenek.

Az offline-termékek vásárlásról szóló 100 komment összesen 172 darab pozitív említést tartalmazott és 113 negatívat (63-64. táblázat). A pozitívak között leggyakrabban az egyszerü és gyors vásárlást (28 és 15 említés) és a széles választékot ( 9 említés) emelték ki, és összesen 58 különböző tulajdonsággal találkoztunk. A negatív említések ezzel szemben sokkal koncentráltabban voltak: az összesen 37 említett tulajdonság közül legtöbbször a szállítás lassúsága (21 említés), a termékek nem megfelelő kategorizálása (sálak és sapkák egyben) (21 említés), és a nem megfelelő választék (15 említés) kerültek kiemelésre.

\begin{tabular}{|l|c|l|c|}
\hline Negatív említés (OT) & Db & Negatív említés (OT) & Db \\
\hline kategorizálás & 21 & választék minősége & 1 \\
\hline szállítás & 21 & bonyolult keresés & 1 \\
\hline választék kicsi & 15 & hány termék látható beállítás & 1 \\
\hline árak & 7 & nem vásárol itt újra & 1 \\
\hline férfi-nő nincs külön & 5 & limitált keresés & 1 \\
\hline design & 3 & ruházat vásárlása online nem jó & 1 \\
\hline hosszú vásárlás & 3 & magas kiszállítási díj & 1 \\
\hline képek hiánya & 3 & szállítási információk két oldalon való megjelenése & 1 \\
\hline ÁFA külön feltüntetve & 3 & keresés & 1 \\
\hline web-shop/honlap minősége gyenge & 2 & szürök nem müködtek & 1 \\
\hline képek minősége & 2 & megerősítő link hiánya & 1 \\
\hline rendezetlen & 2 & akciós termékek miért nincsenek külön & 1 \\
\hline képek kicsik & 2 & méretek hiánya & 1 \\
\hline leírás nem elég részletes & 2 & választék színvonala & 1 \\
\hline kép kevés & 1 & méretek hiánya & 1 \\
\hline unalmas & 1 & FB megosztás & 1 \\
\hline szállítási tájékoztató hiányos & 1 & navigáció & 1 \\
\hline negatív imázs & 1 & márkánkénti csoportosítás hiánya & 1 \\
\hline & & Összesen & 113 \\
\hline
\end{tabular}

\section{4. táblázat: Az offline-termék vásárlásához köthető véleményekben megjelent negatív értékek ( $\mathrm{N}=100$ komment)}

Forrás: az eredmények alapján saját szerkesztés

Az elektronikus-termék vásárlásáról szóló értékelések esetében 195 darab pozitív említéssel, és mindössze 56 darab negatív említéssel találkoztunk (65-66. táblázat). A megjelenő 45 pozitív tulajdonság közül itt is a legtöbben a vásárlási folyamat gyorsaságát és egyszerüségét emelték ki (29-29 említés), valamint itt már sokkal többen említették a honlap átláthatóságát (15 említés). A negatív tulajdonságok között a kínálat szegénységét (14 említés), a könyvek letöltési formátumáról szóló információk hiányát (7 említés), a kötelező regisztrációt és a gyenge designt (5-5 említés) emelték ki a legtöbben. 
A kommentek tartalma az offline-termék és az online-termék vásárlása esetében inkább a negatív vélemények tükrében mutat eltéréseket. Míg a ruházati kiegészítő vásárlása esetében inkább a szállítással és a webshop felépítésével kapcsolatban érkeztek negatív visszajelzések, addig az e-könyvek esetében inkább az elérhető információk köre (formátum, ajánló, méret) került említésre. Az offline-termékek esetében a nagymintás kutatásunkban is az ügyfélszolgálat mellett a csere folyamatának megvalósulása volt az egyik szignifikáns változó az elégedettség esetében, melyet ezek az eredmények is alátámasztanak. Ugyancsak igazolják az eredményeink azt a feltevésünket, hogy ugyanazon webshop használata különböző termékkategóriák vásárlása során eltérő igényeket, elvárásokat támaszt a potenciális vásárlókban. Érdekesség, hogy a pozitív tulajdonságok között mindkét esetben inkább általános jellemzők kerültek említésre, úgymint az egyszerü és gyors vásárlás.

\begin{tabular}{|l|c|l|c|}
\hline Pozitív említés (ET) & Db & Pozitív említés (ET) & Db \\
\hline gyors vásárlási folyamat & 29 & egyértelmú & 1 \\
\hline egyszerú vásárlási folyamat & 29 & regisztráció egyszerú & 1 \\
\hline átlátható & 15 & egyértelmú felépítés & 1 \\
\hline választék nagy & 14 & sorba rendezés & 1 \\
\hline egyszerü kezelhetőség & 12 & korrekt & 1 \\
\hline kategorizálás & 10 & választék jó & 1 \\
\hline árak & 10 & könnyü eligazodni & 1 \\
\hline szállitás & 9 & jó kialakítás & 1 \\
\hline könnyü keresés & 9 & egyértelmú instrukciók & 1 \\
\hline lérások & 6 & regisztrációt nem kellett megismételni & 1 \\
\hline design & 4 & könnyü választás & 1 \\
\hline gyors regisztráció & 4 & sok fizetési és szállítási mód & 1 \\
\hline rendelés rendben & 4 & egyszerú fizetés & 1 \\
\hline kényelmes & 3 & biztonság & 1 \\
\hline elégedett & 2 & gyors letöltés & 1 \\
\hline problémamentes vásárlás & 2 & szállítás kényelmes & 1 \\
\hline megbízható & 2 & felhasználóbarát & 1 \\
\hline gyors keresés & 2 & egyszerü oldal & 1 \\
\hline egyértelmủ rendelési folyamat & 2 & jó instrukciók & 1 \\
\hline érthető & 2 & nincs hírlevél feliratkozás & 1 \\
\hline egyszerü használat & 1 & letisztult & 1 \\
\hline jó szúrés & 1 & második vásárlás élménye & 1 \\
\hline szálítás gyors & 1 & Összesen & 195 \\
\hline
\end{tabular}

\section{5. táblázat: Az e-termék vásárlásához köthető véleményekben megjelent pozitív értékek ( $\mathrm{N}=100$ komment)}

Forrás: az eredmények alapján saját szerkesztés

A vélemények további elemzése céljából kvantitatív eszközöket vettünk igénybe. Minden egyes komment esetében kódoltuk, hogy hány darab pozitív és hány darab negatív véleményt tartalmaz, milyen hosszú az adott komment, a kommenteket csoportosítottuk 
az alapján, hogy inkább negatív, inkább pozitív, vagy semleges értékrendűek ${ }^{17}$, emellett létrehoztuk a delta változókat, melynek során a pozitív említésszámból kivontuk a negatív említésszámot, így egy metrikus változóval is mérni tudjuk a kommentek értékrendjét (67. táblázat).

\begin{tabular}{|l|c|l|c|}
\hline Negatív említés (ET) & Db & Negatív említés (ET) & Db \\
\hline választék kicsi & 14 & szerzők szerinti keresés hiánya & 1 \\
\hline formátumról információ hiány & 7 & lassú betöltődés & 1 \\
\hline regisztráció szükséges & 5 & nem lehet beleolvasni & 1 \\
\hline design & 5 & kategorizálás & 1 \\
\hline leírások hiányosak & 3 & regisztráció lassú & 1 \\
\hline információk hiánya & 2 & letöltés inkább visszaigazoló e-mailböl & 1 \\
\hline ajánlások hiánya & 2 & sok reklám & 1 \\
\hline letöltési instrukciók nem egyértelmüek & 2 & letöltés miért csak saját fiókból & 1 \\
\hline egyéb információk hiánya & 1 & tagolás/kategorizálás & 1 \\
\hline árak & 1 & bizalmas adatokat kértek & 1 \\
\hline oldalszám hiánya & 1 & keresés nehézkes & 1 \\
\hline kiadás éve hiányzik & 1 & méretről információ hiány & 1 \\
\hline & & Összesen & $\mathbf{5 6}$ \\
\hline
\end{tabular}

66. táblázat: Az e-termék vásárláshoz köthető véleményekben megjelent negatív értékek ( $\mathrm{N}=100$ komment)

Forrás: az eredmények alapján saját szerkesztés

\begin{tabular}{|l|c|c|c|c|}
\hline & $\begin{array}{c}\text { Inkább pozitív } \\
\text { komment }\end{array}$ & $\begin{array}{c}\text { Semleges } \\
\text { komment }\end{array}$ & $\begin{array}{c}\text { Inkább negatív } \\
\text { komment }\end{array}$ & Teljes (db) \\
\hline Offline-termék & 53 & 19 & 28 & 100 \\
\hline E-termék & 72 & 14 & 14 & 100 \\
\hline
\end{tabular}

67. táblázat: A vásárláshoz köthető kommentek csoportosítása (N=100 komment)

Forrás: az eredmények alapján saját szerkesztés

A kommentek átlagos hossza az offline-termék vásárlása esetében 161 karakter (szórás=108,9), a leghosszabb komment 627 karaktert tartalmaz, míg a legrövidebb 17 darabot. Az e-termék vásárlása esetében rövidebb kommentekkel találkozhatunk: az átlagos hossz 137 karakter (szórás=85,7), a leghosszabb komment 376 karaktert tartalmaz, míg a legrövidebb mindössze 18-at. Ahogy a korábbi eredmények is mutatták, az offline-termékek esetében átlagosan több negatív említéssel találkozhatunk (átlag ${ }_{\mathrm{OT}}=1,13$, átlag $\mathrm{ET}_{\mathrm{ET}}=0,56$ ), mely különbség szignifikánsnak tekinthető (szig=0,000). Pozitív említésekkel inkább az e-termék vásárlása esetében találkozhatunk (átlag $\mathrm{ET}=1,95$, átlag $\left.{ }_{\mathrm{OT}}=1,72\right)$, ez azonban nem tekinthető szignifikánsnak. Ezek alapján várható, hogy az

\footnotetext{
${ }^{17}$ Vagyis melyikből tartalmaz többet.
} 
e-termék vásárlása esetében a 100 kommentből 72 számít inkább pozitív értékrendűnek, míg az offline-termék vásárlása esetében mindössze 53 (67. táblázat).

A különböző mutatók között az együttmozgást a Pearson-féle korrelációval vizsgáltuk. Az eredmények alapján megállapítható, hogy mind az offline, mind pedig az e-termékek esetében azonos irányú, szignifikáns kapcsolatok figyelhetőek meg. Pozitív irányú, közepes kapcsolat figyelhető meg a kommentek hossza és a negatív említésszám között, vagyis ha az egyik változó értéke növekszik, akkor a másik értéke átlagosan, minden egyéb tényező változatlansága mellett, várhatóan nő. Hasonló kapcsolat figyelhető meg a pozitív említések száma, illetve az átlagos minőségészlelés, az elégedettség, a hagyományos és az e-továbbajánlási szándék, valamint az újravásárlási hajlandóság között (68-69. táblázat).

\begin{tabular}{|l|c|c|c|c|c|c|}
\hline & \multicolumn{2}{|c|}{ Negatív említések száma (OT) } & \multicolumn{3}{c|}{ Pozitív említések száma (OT) } \\
\hline & Pearson-korreláció & Sig. (2 oldali) & $\mathbf{N}$ & Pearson-korreláció & Sig. (2 oldali) & N \\
\hline Karakterszám & 0,528 & 0,000 & 100 & 0,047 & 0,644 & 100 \\
\hline Negatív & 1 & & 100 & $-0,515$ & 0,000 & 100 \\
\hline Pozitív & $-0,515$ & 0,000 & 100 & 1 & & 100 \\
\hline Qual_overall & $-0,493$ & 0,000 & 100 & 0,48 & 0,000 & 100 \\
\hline SAT_átl & $-0,428$ & 0,000 & 100 & 0,43 & 0,000 & 100 \\
\hline WOM_átl & $-0,555$ & 0,000 & 100 & 0,504 & 0,000 & 100 \\
\hline EWOM & $-0,465$ & 0,000 & 100 & 0,354 & 0,000 & 100 \\
\hline BI & $-0,466$ & 0,000 & 100 & 0,409 & 0,000 & 100 \\
\hline
\end{tabular}

68. táblázat: A kommentekben megjelenő negatív és pozitív említések számának (db) kapcsolata a véleményekhez és a vásárláshoz köthető metrikus adatokkal - Offline-termék vásárlása ( $\mathrm{N}=100$ komment $)$

Forrás: az eredmények alapján saját szerkesztés

\begin{tabular}{|l|c|c|c|c|c|c|}
\hline & \multicolumn{3}{|c|}{ Negatív említések száma (ET) } & \multicolumn{3}{c|}{ Pozitív említések száma (ET) } \\
\hline & Pearson-korreláció & Sig. (2 oldali) & $\mathbf{N}$ & Pearson-korreláció & Sig. (2 oldali) & N \\
\hline Karakterszám &, 506 & 0,000 & 100 & 0,138 & 0,644 & 100 \\
\hline Negatív & 1 & & 100 &,- 458 & 0,000 & 100 \\
\hline Pozitív &,- 458 & 0,000 & 100 & 1 & & 100 \\
\hline Qual_overall &,- 438 & 0,000 & 100 &, 261 & 0,009 & 100 \\
\hline SAT_átl &,- 510 & 0,000 & 100 &, 411 & 0,000 & 100 \\
\hline WOM_átl &,- 460 & 0,000 & 100 &, 473 & 0,000 & 100 \\
\hline EWOM &,- 299 & 0,002 & 100 &, 214 & 0,032 & 100 \\
\hline BI &,- 389 & 0,000 & 100 &, 379 & 0,000 & 100 \\
\hline
\end{tabular}

69. táblázat: A kommentekben megjelenő negatív és pozitív említések számának (db) kapcsolata a véleményekhez és a vásárláshoz köthető metrikus adatokkal - E-termék vásárlása $(\mathrm{N}=100$ komment)

Forrás: az eredmények alapján saját szerkesztés 
Ellentétes irányú, közepes kapcsolat figyelhető meg a negatív és a pozitív említések száma között, vagyis az egyik tényező növekedése minden egyéb tényező változatlansága mellett a másik tényező csökkenését hozza magával. Ugyancsak negatív, szignifikáns korreláció áll fenn a negatív említések száma, illetve az átlagos minőségészlelés, az elégedettség, a hagyományos és az e-továbbajánlási szándék, valamint az újravásárlási hajlandóság között.

\subsubsection{Az első és az újravásárlók összehasonlítása}

Független mintás t-próbával megvizsgáltuk az A és a B szcenárió közötti különbségeket is. A t-próba alapján megállapítható, hogy az offline-termék vásárlása esetében nem figyelhető meg szignifikáns eltérés a kommentek tulajdonságai között, míg az e-termék vásárlásakor szignifikáns különbség figyelhető meg a pozitív említések száma között ( sig=0,000): a B szcenárió esetében, tehát amikor az e-termék vásárlása az első vásárlás volt, átlagosan szignifikánsan több pozitív tulajdonságot tartalmazott egy komment, mint az A szcenárió esetében, amikor ez már az újravásárlás volt. Ebből kiindulva a kommentek minősítése is szignifikánsan különbözik az A és a B szcenárió között az etermék vásárlása esetében: a $B$ szcenárió esetében szignifikánsan magasabb a pozitív hangvételü kommentek száma (sig=0,009) $(70-71$. táblázat).

\begin{tabular}{|l|c|c|c|c|}
\hline & Inkább pozitív & Semleges & Negatív & Teljes (db) \\
\hline Offline-termék_A & 28 & 10 & 12 & 50 \\
\hline Offline-termék_B & 25 & 9 & 16 & 50 \\
\hline Teljes (db) & 53 & 19 & 28 & 100 \\
\hline Pearson Chi ${ }^{2}$ sig & 0,672 & & & \\
\hline
\end{tabular}

70. táblázat: Az azonos termékkategóriában történő vásárlások összehasonlítása a vélemények tartalma alapján - Offline-termék vásárlása ( $\mathrm{N}=100$ vélemény)

Forrás: az eredmények alapján saját szerkesztés

\begin{tabular}{|l|c|c|c|c|}
\hline & Inkább pozitív & Semleges & Negatív & Teljes (db) \\
\hline E-termék_A & 30 & 8 & 12 & 50 \\
\hline E-termék_B & 42 & 6 & 2 & 50 \\
\hline Teljes (db) & 72 & 14 & 14 & 100 \\
\hline Pearson Chi ${ }^{2}$ sig & 0,009 & & & \\
\hline
\end{tabular}

71. táblázat: Az azonos termékkategóriában történő vásárlások összehasonlítása a vélemények tartalma alapján - E-termék vásárlása ( $\mathrm{N}=100$ vélemény)

Forrás: az eredmények alapján saját szerkesztés

A kísérletben gyüjtött adatokat arra is szerettük volna felhasználni, hogy validáljuk a nagymintás, 1.000 fös kutatásban felfedett összefüggéseket. Ennek megfelelően a PLS- 
SEM módszertant felhasználva megvizsgáltuk az offline-termék és az e-termék vásárlása közötti különbségeket a minőség, az elégedettség és annak következményei kapcsolatrendszerében az első és az újravásárlás során.

Amennyiben az adatokat aggregálva kezeljük, vagyis nem különböztetjük meg az első és az újravásárlásokat, akkor az adatok a nagymintás kutatáshoz hasonló értékeket mutatnak: nincsen szignifikáns különbség a kapcsolatokban, de jellemzően az offlinetermékekhez tartozó útegyütthatók a magasabbak (67. táblázat).

\begin{tabular}{|l|c|c|}
\cline { 2 - 3 } \multicolumn{1}{c|}{} & $\begin{array}{c}\text { Útegyütthatók } \\
\text { (Offline-termék) }\end{array}$ & $\begin{array}{c}\text { Útegyütthatók } \\
\text { (Online-termék) }\end{array}$ \\
\hline Qual -> SAT & 0,678 & 0,741 \\
\hline SAT -> trad. WOM & 0,880 & 0,860 \\
\hline SAT -> E-WOM & 0,641 & 0,599 \\
\hline SAT -> BI & 0,769 & 0,733 \\
\hline
\end{tabular}

72. táblázat: A minőségészlelés, az elégedettség és következményeinek kapcsolata az offline és e-termék vásárlása esetében - PLS-SEM ( $\mathrm{N}=100$ fö)

Forrás: az eredmények alapján saját szerkesztés

Amennyiben megkülönböztetjük az első és az újravásárlásokat, akkor az újravásárlás esetére szintén jellemző, hogy az offline-terméket és az e-terméket vásárlók között nincs szignifikáns különbség, azonban az első vásárlás esetében jelentős eltérés figyelhető meg az elégedettség és az újravásárlási szándék, valamint az elégedettség és az e-WOM esetében. Mindkét esetben az offline-termékekhez tartozó útegyüttható a szignifikánsan magasabb. Tehát ez alapján megállapíthatjuk, hogy a vizsgált kapcsolatok erősségét a vásárlási szituáció (első vagy újravásárlás) is befolyásolja (73. táblázat).

\begin{tabular}{|l|c|c|c|c|}
\hline & $\begin{array}{c}\text { Útegyüttható (A- } \\
\text { Off-term) } \\
\text { Első vásárlás }\end{array}$ & $\begin{array}{c}\text { Útegyüttható } \\
\text { (B-E-term) } \\
\text { Első vásárlás }\end{array}$ & $\begin{array}{c}\text { Útegyüttható } \\
\text { (B-Off-term) } \\
\text { Újravásárlás }\end{array}$ & $\begin{array}{c}\text { Útegyüttható (A-E- } \\
\text { term) } \\
\text { Ujjravásárlás }\end{array}$ \\
\hline Qual -> SAT & 0,655 & 0,752 & 0,716 & 0,739 \\
\hline SAT -> tr. WOM & 0,860 & 0,835 & 0,901 & 0,871 \\
\hline SAT -> E-WOM & 0,655 & 0,403 & 0,656 & 0,704 \\
\hline SAT -> BI & 0,767 & 0,616 & 0,781 & 0,799 \\
\hline
\end{tabular}

73. táblázat: A minőségészlelés, az elégedettség és következményeinek alakulása az első és az újravásárlás esetében - PLS-SEM ( $\mathbf{N = 1 0 0 ~ f o ̈ ) ~}$

Forrás: az eredmények alapján saját szerkesztés 


\section{AZ EREDMÉNYEK INTERPRETÁCIÓJA, KÖVETKEZTETÉSEK}

Jelen tanulmány célja az volt, hogy az e-kiskereskedelem négy különböző szegmensében megvizsgáljon egy az offline világból már jól ismert kapcsolatrendszert, vagyis a vásárláshoz köthető észlelt minőség, az elégedettség, az újravásárlási és a hagyományos, valamint az elektronikus továbbajánlási szándék közötti kapcsolatot, és a szegmensek esetében kapott eredményeket összehasonlítsa. A kutatás a szakirodalom alapos áttanulmányozásával kezdődött, melynek középpontjában a feltárt e-szolgáltatásminőség koncepciók részletes feltárása állt. Az eredmények alapján megállapítható, hogy a webshophoz kapcsolódó minőségészlelés többdimenziós fogalom, és hogy e fogalom definíciójának, vagyis hogy az adott online üzlet milyen szinten képes a hatékony nézelődést, megrendelést, fizetést és a vásárlás teljesítését támogatni, az elemzett mérési koncepciók egy része nem felel meg. Ezek a koncepciók jellemzően a kiszállítás lebonyolítását vették figyelembe. Az eredmények alapján megállapítható, hogy az eszolgáltatásminőséget az alábbi négy dimenzió mentén érdemes mérni:

1. A tényleges honlap, vagyis a webshop kialakításának minősége, amely jellemzően a honlapon fellelhető információkat foglalja magában, vagyis a vásárlói döntési szakasz információgyüjtési szakaszától az üzletválasztásig bezárólag fedi le a döntési szituációt.

2. A vásárlás lebonyolításának minősége, vagyis az adott webshopban milyen körülmények között történt meg a tényleges vásárlás és az esetleges kiszállítás.

3. Az észlelt biztonság, vagyis a vásárlás során hogyan értékelték a vásárlók az adataik védelmét.

4. Az ügyfélszolgálat értékelése, vagyis az, hogy milyen lehetőségeket kínál a webshop az egyébként személytelen vásárlási folyamatban a személyes kapcsolatra, és a felmerülő kérdések, illetve problémák kezelésére.

Mivel a kutatás az e-kereskedelem Francis és White (2003) által megalkotott négy szegmensében elkülönítve vizsgálta meg a minőségészlelést, ezért egy olyan validált skálát kellett a szakirodalomból választani, mely figyelembe veszi ezeknek a piacoknak a sajátosságait, például, hogy az e-szolgáltatások esetében a szolgáltatás vásárlása és igénybevétele egy online fiókban történik (pl. e-banking), míg az offline-szolgáltatások esetében fontos a voucher e-mailes elküldése, a visszaigazolások kezelése. Ezeket az 
eltéréseket a Francis (2009) által megalkotott mérési koncepció szem előtt tartja, vagyis a különböző dimenziókhoz tartozó mérési változók a kategóriák esetében különbözhetnek. Az empirikus kutatás során ezt a koncepciót alkalmaztuk az elektronikus szolgáltatásminőség mérésére.

A kutatási kérdések megválaszolására egy nagymintás (1.000 fö), online kérdőíves megkérdezést valósítottunk meg az elmúlt három hónap során, online vásárlókat alapsokaságként tekintve. A mintavétel során az 50-50\%-os kvótát alkalmaztunk, vagyis a minta fele olyan egyéneket tartalmazott, akik valamilyen offline teljesítésü terméket vagy szolgáltatást vásároltak, míg a másik felét az elektronikus terméket vagy szolgáltatást vásárlók alkották. A legfontosabb kérdések ennek a kutatásnak az eredményei alapján már megválaszolásra kerültek, mégis a kutatási limitációkat figyelembe véve, vagyis hogy a megkérdezettek nem ugyanazokat a webshopokat értékelték, valamint nem tudtuk az első és az újravásárlókat megkülönböztetni egymástól, az eredmények validálása céljából egy 100 fős kísérletet is megvalósítottunk. Ennek során egy fiktív webshopot használva mértük a résztvevők minőségészlelését, elégedettségét, újravásárlási és továbbajánlási szándékát, valamint nyitott kérdéseket használva a mögöttes indokok, a vélemények alakulásának miértjét is feltárhattuk.

\subsection{Főbb következtetések}

A nagymintás online kérdőíves kutatás során az elektronikus szolgáltatásminőség teljes értékelése (azt) feltételezi, hogy a vásárlók a vásárlók a webshophoz és a tényleges vásárláshoz köthető tapasztalatok mellett az ügyfélszolgálattal is kapcsolatba lépjenek, tehát ennek a személytelen, automatizált vásárlási folyamatnak az egyetlen személyes jellemzőjével kapcsolatban is rendelkeznek információkkal, valamint véleményt tudnak alkotni a webshop által nyújtott biztonságról is. Parasuraman és társai (2005) azonban felhívják arra a figyelmet, hogy az ügyfélszolgálathoz kapcsolódó kommunikáció értékelése nem minden vásárlás esetében lehetséges, mert a probléma- vagy kérdésmentes szituációkban általában nem lép az egyén kapcsolatba a vállalattal. Jelen kutatás esetében összesen 481 olyan válaszadó volt, akik az ügyfélszolgálattal kapcsolatban valamely mérési változót nem tudtak értékelni, és közülük legtöbben a problémás esetek és a kérdések kezelésével kapcsolatban nem rendelkeztek információval. Érdekes tendencia azonban, hogy a válaszadók egy jelentős csoportja (416fö) a biztonsághoz kapcsolódóan sem rendelkezett teljes körü információval. Közülük legtöbben a bankkártyaadatok garantált védelmével (300 fö), illetve a személyes adatok kezelésével (200 fö) 
kapcsolatban nem tudtak nyilatkozni. Ebbe a csoportba jellemzően azok az egyének tartoztak, akik valamilyen offline-termék vásárlását értékelték a megkérdezés során, ezért magyarázatként a hiányzó információkkal kapcsolatban az szolgálhat, hogy ők az online fizetés helyett inkább a személyes fizetést választották, illetve nem regisztrált vásárlóként hajtották végre a folyamatot. Ezzel a kérdéskörrel azonban a nagymintás kutatásunk nem foglalkozott, így a biztonsággal kapcsolatos hiányzó információk okának feltárását jövőbeni kutatási irányként jelöljük meg.

Elemzésünk során a felállított modell és hipotézisek vizsgálatára a strukturális modellezést használtuk, amely azonban a hiányzó adatok tekintetében igen érzékeny módszer. Mivel a hiányzó adatok átlaggal való helyettesítése (casewise módszer) jelentős eltéréseket eredményezetta modellünkben (7. számú melléklet), ezért a hiányzó adatokkal rendelkezőket külön csoportként kezeltük. Így a modell értékelése négy különböző esetben történt:

1. a teljes tapasztalattal rendelkezők ( $\mathrm{N}=377$ fö),

2. az ügyfélszolgálattal kapcsolatban hiányos tapasztalattattal rendelkezők $(\mathrm{N}=207$ fó),

3. a biztonsággal kapcsolatban hiányos tapasztalattattal rendelkezők ( $\mathrm{N}=142$ fó),

4. az ügyfélszolgálattal és a biztonsággal kapcsolatban hiányos tapasztalattal rendelkezők ( $\mathrm{N}=274$ fö).

A kutatási eredmények részletese bemutatásakor (4.1 fejezet) mind a négy esetet kimerítően jellemeztük, azonban jelen konklúzió mindössze az első és a második eset eredményeit taglalja, mivel a biztonsággal kapcsolatos hiányos adatok miértjére nincs pontos válaszunk, míg azt tudjuk, hogy az ügyfélszolgálat hiányos értékelése a problémamentes vásárlási folyamat eredményeként született.

\subsection{A hipotézisvizsgálat eredményei}

A szakirodalom és a pilot kutatásink alapján felállított hipotézisek vizsgálatára a PLSSEM útmodellezéssel került sor. Annak elemzésére, hogy a feltételezett kapcsolatok léteznek-e és szignifikánsak-e a PLS-SEM keretében a bootstrapping módszert alkalmazva (1.000 darab minta), a t-próba eredményeit felhasználva került sor.

Az eredmények alapján megállapíthatjuk, hogy az offline-termékek esetében csak a vásárlás lebonyolításának minősége, vagyis a megrendelési folyamat milyensége és a 
kiszállítás, illetve a teljes tapasztalattal rendelkezők esetében az ügyfélszolgálat értékelése bír szignifikáns pozitív hatással az elégedettségre. A webshop által nyújtott észlelt biztonság hatása nem szignifikáns, tehát megállapíthatjuk, hogy jelen vásárlási szituációban az elégedettséggel kapcsolatban ez nem kulcstényező. Ugyanez mondható el a konkrét, fizikai webshopról is. Ezek alapján a feltételezett hipotézisek közül kettőt nem fogadhatunk el (H1.1, H1.3).

Ugyancsak két hipotézis kerül elvetésre az e-szolgáltatások esetében (H1.1, H1.2), ahol a vásárlás lebonyolításának minősége, vagyis a létrehozott fiók kezelhetősége és müködése, valamint ennek a fióknak a tényleges minősége nem bír szignifikáns hatással az elégedettség alakulására. Azok esetében, akiknél az ügyfélszolgálattal kapcsolatban rendelkezésre áll információ, az releváns, pozitív hatású faktorként jelenik meg, és ebben az esetben e tényező hatása erősebb, mint az észlelt biztonságé. Az e-szolgáltatások vásárlása során az észlelt biztonság a másik szignifikáns, pozitív hatású dimenzió. Az észlelt biztonság alakulása az e-termékek esetében is pozitív, szignifikáns hatással bír az elégedettség szintjére, az összes többi hipotézis azonban elvetésre került (H1.1, H1.2, H1.4). Az offline-szolgáltatások esete az egyedüli, amikor különbség figyelhető meg a teljes tapasztalattal és az ügyfélszolgálattal kapcsolatban hiányos tapasztalattal rendelkezők esetében, ugyanis mindkét szituációban csak egy hipotézist tartunk meg, azonban nem ugyanazt a feltevést. A teljes tapasztalattal rendelkezök esetében, tehát akiknek volt valamilyen kapcsolata az ügyfélszolgálattal, a vásárlás lebonyolításának dimenziója bír szignifikáns pozitív hatással az elégedettségre, míg az ilyen jellegü, személyes „kapcsolattal” nem rendelkezők esetében az észlelt biztonság hatása szignifikáns.

Összességében tehát megállapítható, hogy a különböző e-kiskereskedelmi csoportokban a vizsgált minőségdimenziók közül nem mindegyik bír szignifikáns, pozitív hatással az elégedettség alakulására. A feltételezett kapcsolatok igazolására irányuló hipotézisvizsgálat eredményeit az 74. táblázat tartalmazza.

Az elégedettség és annak következményei közötti pozitív, szignifikáns kapcsolatok egy kivétellel (offline-szolgáltatások vásárlása, az ügyfélszolgálat tekintetében hiányos tapasztalattal rendelkezők) minden esetben elfogadásra kerültek, tehát a hipotéziseinket megtartjuk. 
Az elégedettség és következményei közötti kapcsolatok eltéréseinek vizsgálatára a négy szegmens esetében az MGA módszert alkalmaztuk, és a szignifikáns különbségek feltérképezésére a PLS-MGA valószínűségi mutatót használtuk ${ }^{18}$.

\begin{tabular}{|l|l|l|c|c|}
\hline & $\begin{array}{l}\text { Offline- } \\
\text { termék }\end{array}$ & $\begin{array}{l}\text { Offline- } \\
\text { szolgáltatás }\end{array}$ & E-termék & E-szolg \\
\hline $\begin{array}{l}\text { H1: Az elektronikus szolgáltatásminőség dimenziói pozitív } \\
\text { hatással bírnak az elégedettség alakulására. }\end{array}$ & & & & \\
\hline $\begin{array}{l}\text { H1.1: A konkrét webshopminőség dimenziója szignifikáns, } \\
\text { pozitív hatással bír az elégedettségre. }\end{array}$ & Elvet & Elvet & Elvet & Elvet \\
\hline $\begin{array}{l}\text { H1.2: A vásárlás lebonyolításának minősége szignifikáns, } \\
\text { pozitív hatással bír az elégedettségre }\end{array}$ & Elfogad & Elfogad & Elvet & Elvet \\
\hline $\begin{array}{l}\text { H1.3: Az észlelt biztonság dimenziója szignifikáns, pozitív } \\
\text { hatással bír az elégedettségre }\end{array}$ & Elvet & Elvet & Elfogad & Elfogad \\
\hline $\begin{array}{l}\text { H1.4: Az ügyfélszolgálat minőségének dimenziója szignifikáns, } \\
\text { pozitív hatással bír az elégedettségre }\end{array}$ & Elfogad & Elvet & Elvet & Elfogad \\
\hline $\begin{array}{l}\text { H2: Az elégedettség minden egyes elektronikus kereskedelmi } \\
\text { kategóriában pozitív hatással bír az újravásárlási szándékra. }\end{array}$ & Elfogad & Elfogad & Elfogad & Elfogad \\
\hline $\begin{array}{l}\text { H4: Az elégedettség minden egyes e-kereskedelmi kategóriában } \\
\text { pozitív hatással bír a hagyományos továbbajánlási szándékra. }\end{array}$ & Elfogad & Elfogad & Elfogad & Elfogad \\
\hline $\begin{array}{l}\text { H6: Az elégedettség minden egyes e-kereskedelmi kategóriában } \\
\text { pozitív hatással bír az elektronikus továbbajánlási szándékra. }\end{array}$ & Elfogad & Elfogad & Elfogad & Elfogad \\
\hline
\end{tabular}

\section{4. táblázat: A hipotézisvizsgálat eredménye a nagymintás kutatás eredményei} alapján - PLS-SEM módszertan alkalmazásával

Forrás: az eredmények alapján saját szerkesztés

Az elégedettség és következményei közötti kapcsolatok eltéréseinek vizsgálatára a négy szegmens esetében az MGA módszert alkalmaztuk, és a szignifikáns különbségek feltérképezésére a PLS-MGA valószínüségi mutatót használtuk. Az elégedettség és a tradicionális továbbajánlási szándék esetében a teljes tapasztalattal rendelkezők körében a feltételezett hat hipotézis közül csak egy került feltétel nélküli megtartásra (H5.3), mely szerint az e-szolgáltatást vásárlók esetében a pozitív irányú kapcsolat szignifikánsan alacsonyabb, mint az offline-termékek esetében. A többi esetben a különbségek iránya igazolódott, azonban az eltérések nem tekinthetőek szignifikánsnak. Ez alapján látható, hogy csak a két szélsőérték között figyelhető meg releváns eltérés. Ugyanez mondható el az elégedettség és az elektronikus továbbajánlási hajlandóság kapcsolatáról is.

Az elégedettség és az újravásárlási szándék esetében a felállított hipotézisek közül kettő került megtartásra (H3.3 és H3.6), azonban a szegmensek közötti kapcsolatok sorrendje az elvártaktól eltérően alakult: az e-terméket és az offline-szolgáltatást vásárlók sorrendje megcserélődik, tehát ez a kapcsolat az e-termékek esetében gyengébb, mint az offline-

\footnotetext{
${ }^{18}$ A mutató alapján akkor van szignifikáns különbség az elemzésbe bevont változók között, ha annak értéke kisebb, mint 0,05, vagy nagyobb, mint 0,95 (Sarstedt el al. 2011).
} 
szolgáltatásoknál. A szegmensek közötti eltérésekre vonatkozó hipotézisvizsgálat eredményeit a 75. táblázat összegzi.

H3: Az elégedettség újravásárlási szándékra gyakorolt hatása a különbözö e-kereskedelmi kategóriákban szignifikánsan eltér.

H3.1: Az elégedettség erösebb pozitív hatással bír az újravásárlási szándékra az offline-termékek esetében, mint az e-termékek esetében. H3.2: Az elégedettség erősebb pozitív hatással bír az újravásárlási szándékra az offline-termékek esetében, mint az offline-szolgáltatások esetében.

H3.3: Az elégedettség erősebb pozitív hatással bír az újravásárlási szándékra az offline-termékek esetében, mint az e-szolgáltatások esetében. H3.4: Az elégedettség erősebb pozitív hatással bír az újravásárlási szándékra az e-termékek esetében, mint az offline-szolgáltatások esetében. H3.5: Az elégedettség erősebb pozitív hatással bír az újravásárlási szándékra az e-termékek esetében, mint az e-szolgáltatások esetében. H3.6: Az elégedettség erősebb pozitív hatással bír az újravásárlási szándékra az offline-szolgáltatások esetében, mint az e-szolgáltatások esetében.

H5: Az elégedettséghagyományos továbbajánlási szándékra gyakorolt hatása a különböző e-kereskedelmi kategóriákban szignifikánsan eltér.

H5.1: Az elégedettség erősebb pozitív hatással bír a hagyományos továbbajánlási szándékra az offline-termékek esetében, mint az e-termékek esetében.

H5.2: Az elégedettség erősebb pozitív hatással bír a hagyományos továbbajánlási szándékra az offline-termékek esetében, mint az offlineszolgáltatások esetében.

H5.3: Az elégedettség erősebb pozitív hatással bír a hagyományos továbbajánlási szándékra az offline-termékek esetében, mint az eszolgáltatások esetében.

H5.4: Az elégedettség erősebb pozitív hatással bír a hagyományos továbbajánlási szándékra az e-termékek esetében, mint az offlineszolgáltatások esetében.

H5.5: Az elégedettség erösebb pozitív hatással bír a hagyományos továbbajánlási szándékra az e-termékek esetében, mint az e-szolgáltatások esetében.

H5.6: Az elégedettség erősebb pozitív hatással bír a hagyományos továbbajánlási szándékra az offline-szolgáltatások esetében, mint az eszolgáltatások esetében.

H7: Az elégedettség elektronikus továbbajánlási szándékra gyakorolt hatása a különböző e-kereskedelmi kategóriákban szignifikánsan eltér.

H7.1: Az elégedettség erősebb pozitív hatással bír az elektronikus továbbajánlási szándékra az offline-termékek esetében, mint az e-termékek esetében.

H7.2: Az elégedettség erősebb pozitív hatással bír az elektronikus továbbajánlási szándékra az offline-termékek esetében, mint az offlineszolgáltatások esetében.

H7.3: Az elégedettség erősebb pozitív hatással bír az elektronikus továbbajánlási szándékra az offline-termékek esetében, mint az eszolgáltatások esetében.

H7.4: Az elégedettség erősebb pozitív hatással bír az elektronikus továbbajánlási szándékra az e-termékek esetében, mint az offlineszolgáltatások esetében.

H7.5: Az elégedettség erösebb pozitív hatással bír az elektronikus továbbajánlási szándékra az e-termékek esetében, mint az e-szolgáltatások esetében.

H7.6: Az elégedettség erősebb pozitív hatással bír az elektronikus továbbajánlási szándékra az offline-szolgáltatások esetében, mint az eszolgáltatások esetében.

Részben elfogad

Erösebb, de nem szignifikáns a különbség

Részben elfogad

Erösebb, de nem szignifikáns a különbség

Elfogad

\section{Részben elfogad}

Erösebb, de nem szignifikáns a különbség

Részben elfogad
Erösebb, de nem szignifikáns a különbség

Részben elfogad

Erösebb, de nem szignifikáns a különbség

a

E

Erösebb, de nem szignifikáns a

\begin{tabular}{|c|}
$\begin{array}{c}\text { Részben elfogad } \\
\text { Erösebb, de nem szignifikáns a különbség }\end{array}$ \\
Elfogad \\
$\begin{array}{c}\text { Részben elfogad } \\
\text { Erösebb, de nem szignifikáns a különbség }\end{array}$ \\
$\begin{array}{c}\text { Részben elfogad } \\
\text { Erösebb, de nem szignifikáns a különbség }\end{array}$ \\
$\begin{array}{c}\text { Részben elfogad } \\
\text { Erösebb, de nem szignifikáns a különbség }\end{array}$
\end{tabular}

\section{5. táblázat: A hipotézisvizsgálat eredménye a nagymintás kutatás eredményei alapján - PLS-SEM, MGA módszertan alkalmazásával}

Forrás: az eredmények alapján saját szerkesztés 
A szegmensek közötti különbségekre vonatkozó hipotézisvizsgálat eredményei az ügyfélszolgálattal kapcsolatban hiányos tapasztalattal rendelkezők esetében eltérő képet mutatnak. Az elégedettség és a tradicionális továbbajánlás esetében már az elvárt sorrend is teljesen átalakul: a legerősebb hatás az e-termékek esetében figyelhető meg, melyet az offline-szolgáltatások, majd az offline-termékek követnek. A felállított hipotézisek közül egy került elfogadásra (H5.5), mely szerint az e-szolgáltatást vásárlók esetében az elégedettség hatása a hagyományos továbbajánlásra szignifikánsan alacsonyabb, és mindössze három került részben elfogadásra (H5.3, H5.4, H5.6). A másik két kapcsolat, vagyis az elégedettség és az e-továbbajánlás, valamint az újravásárlás közötti hatás esetében egy hipotézist sem tudtunk feltétel nélkül megtartani, és részben elfogadni is csak két hipotézist tudunk (H7.2, H7.4). Nagymintás kutatásunkat egy kísérlettel egészítettük ki, melynek során a vélemények alakulásának megértését, illetve a korábban bemutatott eredmények validálását tüztük ki célul az offline-termékek (ruházati kiegészítő) és az e-termékek (e-könyv) esetében.

A megvalósított vásárláshoz köthető véleményekkel kapcsolatban megállapítható, hogy az offline-termékek esetében a leggyakrabban előforduló pozitív értékek az egyszerü és gyors vásárlás, valamint a széles választék voltak, és összesen 58 különbözö tulajdonsággal találkoztunk. A negatív említések ezzel szemben sokkal koncentráltabban jelentek meg: az összesen 37 említett tulajdonság közül legtöbbször a szállítás lassúsága ${ }^{19}$, a termékek nem megfelelő és így a keresést nehezítő kategorizálása, valamint a gyenge választék kerültek kiemelésre.

Az elektronikus-termék vásárlásáról szóló értékelések esetében 45 pozitív tulajdonság került megnevezésre, és itt is a legtöbben a vásárlási folyamat gyorsaságát és egyszerűségét emelték ki - tehát az online vásárlás egyik alapvető előnyét -, valamint a honlap átláthatóságát; a termékek kategorizálásával is jobban meg voltak elégedve a vásárlók, habár az alkalmazott design ugyanaz volt. A negatív tulajdonságok között a kínálat szegénységét, a könyvek letöltési formátumáról szóló információk hiányát, a kötelező regisztrációt ${ }^{20}$ és a gyenge designt emelték ki a legtöbben.

A vélemények tartalma az offline-termék és az online-termék vásárlása esetében a negatív tulajdonságokban mutat eltéréseket: a ruházati kiegészítő vásárlása esetében inkább a szállítással és a webshop felépítésével kapcsolatban érkeztek negatív visszajelzések, az

\footnotetext{
${ }^{19}$ A megvalósított vásárlás keretében a megjelölt kiszállítási időt 10 napban határoztuk meg.

${ }^{20}$ Ahogy a legtöbb webshop esetében, az offline-terméket itt is meg lehetett vásárolni regisztráció nélkül.
} 
e-könyvek esetében pedig az elérhető információk körére vonatkozóan (formátum, ajánló, méret). Az offline-termékek esetében az ügyfélszolgálat mellett a csere folyamatának megvalósulása volt az egyik szignifikáns változó az elégedettség alakulásakor nagymintás kutatásunkban is, amit a kísérlet eredményei is alátámasztanak. Ezek a vélemények igazolják, hogy különböző termékkategóriák ugyanazon webshopban megvalósított vásárlása során eltérő igények és elvárások keletkeznek a potenciális vásárlókban.

A véleményeket kvantitatív eszközökkel is megvizsgáltuk. Az eredmények alapján pozitív irányú, közepes kapcsolat figyelhető meg a kommentek hossza és a negatív említésszám között, vagyis ha az egyik változó értéke növekszik, akkor a másik értéke átlagosan, minden egyéb tényező változatlansága mellett, várhatóan nő, vagyis több negatív tapasztalat esetében várhatóan hosszabb kommentek születnek. Ugyancsak pozitív, szignifikáns kapcsolat figyelhető meg a véleményekben megjelenő pozitív tulajdonságok száma, illetve az átlagos minőségészlelés, az elégedettség, a hagyományos és az e-továbbajánlási szándék, valamint az újravásárlási hajlandóság szintje között. Ez a kapcsolat a negatív tulajdonságok mennyisége tekintetében ellentétesen alakul. A kísérlet adatai alapján az A és a B szcenárió közötti különbségeket is megvizsgáltuk. A kommentekben említett tulajdonságok, leíró jellemzők esetében csak az e-termék vásárlásakor figyelhető meg szignifikáns különbség: a B szcenárió esetében, tehát amikor az e-termék vásárlása az első vásárlás volt, átlagosan szignifikánsan több pozitív tulajdonságot tartalmazott egy komment, mint az A szcenárió esetében, amikor ez már az újravásárlás volt.

A nagymintás kutatási eredmények validálása céljából a PLS-SEM módszertant felhasználva megvizsgáltuk az offline-termék és az e-termék vásárlása közötti különbségeket a feltételezett kapcsolatrendszerben. Az eredmények plusz hozadéka, hogy ebben az esetben mindenki ugyanazt a honlapot használta és értékelte, és mivel egy fiktív webshopban vásároltak, amit senki sem ismert korábban, meg tudtuk különböztetni az első és az újravásárlás közötti lehetséges értékelését. Az adatok aggregált elemezése során, vagyis amikor nem kerül az első és az újravásárlás megkülönböztetésre, az eredmények a nagymintás kutatáshoz hasonló értékeket mutatnak: nincs szignifikáns különbség a kapcsolatokban, és az elégedettség és következményei esetében az offlinetermékekhez tartozó útegyütthatók a magasabbak. 
Az első és az újravásárlás szeparált elemzésekor már megfigyelhetőek eltérések a nagymintás kutatás esetében. Az újravásárlási szituációban az offline-terméket és az eterméket vásárlók között ebben az esetben sincs szignifikáns különbség, azonban a hatások erősségében megfigyelhető eltérés: az elégedettség és a hagyományos továbbajánlás kapcsolata az offline-termék vásárlásakor, míg az elégedettség hatása az elektronikus WOM-ra és az újravásárlási szándékra az e-termék esetében magasabb. Ezzel szemben az első vásárlási szituációban szignifikáns eltérés figyelhető meg az elégedettség és az újravásárlási szándék, valamint az elégedettség és az e-WOM esetében. Mindkét esetben az offline-termékekhez tartozó útegyüttható a szignifikánsan magasabb. Az elégedettség hatása a hagyományos továbbajánlásra szintén az offline-termék vásárlásakor magasabb, azonban ez az eltérés nem tekinthető szignifikánsnak. Ezek alapján megállapítható, hogy a vizsgált kapcsolatok erősségét a vásárlási szituáció (első vagy újravásárlás) is befolyásolja (76. táblázat).

\begin{tabular}{|c|c|c|c|}
\hline & \multirow{2}{*}{$\begin{array}{l}\text { Nagymintás } \\
\text { kutatás }\end{array}$} & \multicolumn{2}{|c|}{ Kísérleti kutatás } \\
\hline & & Első vásárlás & Újravásárlás \\
\hline $\begin{array}{l}\mathrm{H} 2: \text { Az elégedettség minden egyes } \\
\text { elektronikus kereskedelmi kategóriában } \\
\text { pozití hatással bír az újravásárlási } \\
\text { szándékra. }\end{array}$ & Elfogad & Elfogad & Elfogad \\
\hline \multicolumn{4}{|l|}{$\begin{array}{l}\text { H3: Az elégedettség újjravásárlási } \\
\text { szándékra gyakorolt hatása a különböző e- } \\
\text { kereskedelmi kategóriákban szignifikánsan } \\
\text { eltér. }\end{array}$} \\
\hline $\begin{array}{l}\text { H3.1: Az elégedettség erősebb pozitív } \\
\text { hatással bír az újravásárlási szándékra az } \\
\text { offline-termékek esetében, mint az e- } \\
\text { termékek esetében. }\end{array}$ & $\begin{array}{l}\text { Részben elfogad } \\
\text { Erösebb, de nem } \\
\text { szignifikáns a különbség }\end{array}$ & Elfogad & Elvet \\
\hline $\begin{array}{l}\text { H4: Az elégedettség minden egyes e- } \\
\text { kereskedelmi kategóriában pozitív hatással } \\
\text { bír a hagyományos továbbajánlási } \\
\text { szándékra. }\end{array}$ & Elfogad & Elfogad & Elfogad \\
\hline \multicolumn{4}{|l|}{$\begin{array}{l}\text { H5: Az elégedettség minden egyes e- } \\
\text { kereskedelmi kategóriában pozitív hatással } \\
\text { bír a hagyományos továbbajánlási } \\
\text { szándékra. }\end{array}$} \\
\hline $\begin{array}{l}\text { H5.1: Az elégedettség erősebb pozitív } \\
\text { hatással bír a hagyományos továbbajánlási } \\
\text { szándékra az offline-termékek esetében } \\
\text { mint az e-termékek esetében. }\end{array}$ & $\begin{array}{l}\text { Részben elfogad } \\
\text { Erösebb, de nem } \\
\text { szignifikáns a különbség }\end{array}$ & $\begin{array}{l}\text { Részben elfogad } \\
\text { Erösebb, de nem } \\
\text { szignifikáns a különbség }\end{array}$ & $\begin{array}{l}\text { Részben elfogad } \\
\text { Erösebb, de nem } \\
\text { szignifikáns a különbség }\end{array}$ \\
\hline $\begin{array}{l}\text { H6: Az elégedettség minden egyes e- } \\
\text { kereskedelmi kategóriában pozitív hatással } \\
\text { bír az elektronikus továbbajánlási } \\
\text { szándékra. }\end{array}$ & Elfogad & Elfogad & Elfogad \\
\hline \multicolumn{4}{|l|}{$\begin{array}{l}\text { H7: Az elégedettség elektronikus } \\
\text { továbbajánlási szándékra gyakorolt hatása } \\
\text { a különböző e-kereskedelmi kategóriákban } \\
\text { szignifikánsan eltér. }\end{array}$} \\
\hline $\begin{array}{l}\text { H7.1: Az elégedettség erősebb pozitív } \\
\text { hatással bír az elektronikus továbbajánlási } \\
\text { szándékra az offline-termékek esetében, } \\
\text { mint az e-termékek esetében. }\end{array}$ & $\begin{array}{l}\text { Részben elfogad } \\
\text { Erösebb, de nem } \\
\text { szignifikáns a különbség }\end{array}$ & $\begin{array}{l}\text { Részben elfogad } \\
\text { Erösebb, de nem } \\
\text { szignifikáns a különbség }\end{array}$ & $\begin{array}{l}\text { Részzben elfogad } \\
\text { Erösebb, de nem } \\
\text { szignifikáns a különbség }\end{array}$ \\
\hline
\end{tabular}

76. táblázat: A hipotézisvizsgálat eredményei - kísérleti és nagymintás kutatás összehasonlítása 


\subsection{Elméleti és gyakorlati relevanciák}

Tanulmányunk során a kiskereskedelem egyik legdinamikusabban fejlődő területét, az ekiskereskedelmet vettük górcső alá, és ennek is egy marketingközpontú elemzését végeztük el. Habár a vásárlási folyamatokról, döntésekről számos információ áll rendelkezésünk az „offline” világból, mégis az egyre növekvő tapasztalatok és szakértői vélemények azt mutatják, hogy az interneten bizonyos eltérések figyelhetők meg. Ebből kiindulva célunk az volt, hogy egy jól ismert összefüggésrendszert, vagyis a minőség, az elégedettség, az újravásárlási és a továbbajánlási szándék kapcsolatát megvizsgáljuk a hazai e-kiskereskedelem esetében, és a felállított hipotézisrendszer megvizsgálásával új eredményeket nyújtunk az elmélet számára. További motivációkat a szakirodalom alapos áttanulmányozásából nyertünk, mely szerint a vásárlási folyamatokat nem érdemes egyben vizsgálni - ahogy a korábbi tanulmányok többsége tette -, hanem érdemes a különböző lehetséges e-kiskereskedelmi csoportok közötti eltéréseket is elemezni és megérteni. Tanulmányunkban csoportképző ismérvként a vásárolt jószág jellegét és a teljesítés módját választottuk, vagyis elkülönítve elemeztük az offline teljesítésü termékek és szolgáltatások, valamint az elektronikus teljesítésü termékek és szolgáltatások vásárlását. Ez a fajta elkülönített elemzés egy új megközelítést jelent a szakirodalomban, és az eredmények a webshoptervezés és -üzemeltetés szempontjából számos izgalmas nézőponttal szolgálhatnak. A feltárt különbségeket érdemes azoknak is figyelembe venni, akik olyan webshopot üzemeltetnek, mely egyszerre többfajta termékek és szolgáltatást is értékesít. Bizonyított, hogy a változatos kínált nagyobb elégedettséget eredményez (Agárdi, 2004), azonban a feltárt eltérő vásárlói elvárásokat is figyelembe kell venni a tervezés során.

A disszertáció az online fogyasztói elégedettségméréssel foglalkozó tanulmánysorozatunk záró része, mely az e-szolgáltatásminőség és az elégedettség mellett a továbbajánlási és az újravásárlási szándék témakörével is foglalkozik. A különböző modellek alapján megállapítható, hogy az online fogyasztói elégedettségmérés valóban egy újfajta gondolkodásmódot igényel, melynek legjelentősebb oka az internet mint csatorna nyújtotta sajátosságokban keresendő, vagyis az interaktivitásban, a személyre szabásban, a széles körü, könnyen elérhető kínálatokban, a közösség szerepében.

Az e-szolgáltatásminőség mérésére kialakított mérési skálák felhasználásával a vállalatok képesek a fogyasztói elvárásokat, igényeket megismerni, és ezáltal sikeresebb, 
versenyképes stratégiát létrehozni. Fontos kiemelni, hogy a webshoppal kapcsolatos észlelt minőség a bemutatott elméletek alapján nemcsak az ott töltött idő alatti interakciók minőségétől, a honlap felépítésétől, illetve használhatóságától függ, hanem a vásárlás előtti, illetve utáni tevékenységek is jelentősen befolyásolják a vásárlók észlelését, így a szájreklám, a márkaimázs, a szállítás, vagy a panaszkezelés. Ez egy összetettebb mérési koncepciót igényel az akadémiai élet szemszögéből, míg a vállalati szakemberek részéről egyfajta komplex stratégiai gondolkodást, melyben számos belső és külső terület például marketing, IT, logisztika, pénzügy, kiszállítással megbízott partner, call-center összehangolt müködésére van szükség. A fogyasztók által észlelt minőség, illetve ezen keresztül a fogyasztói elégedettség szintjének feltérképezésével a vállalatok online tevékenysége tovább fejleszthető, az elégedett fogyasztók hosszú távon lojálissá tehetők, és ezáltal a vállalat eredményessége is növelhető.

Ha a webshopjukhoz köthető elégedettséget szeretnék javítani, akkor a vállalatoknak első körben a kutatásunk által relevánsnak talált dimenziókat kell fejleszteniük, mivel az ezekkel kapcsolatos minőségészlelés növekedésével nagyobb pozitív változás érhető el az elégedettségben, illetve az elégedettség közvetítésével a hagyományos és az elektronikus továbbajánlási szándékban, valamint az újravásárlási hajlandóságban. Eredményeinkből láthatjuk, hogy a kutatás során megvizsgált e-szolgáltatásminőség dimenziók hatása a négy csoporton belül eltérően alakul. Egyik esetben sem bír releváns hatással a webshop tényleges, fizikai megjelenítése az elégedettség alakulására. Ennek oka az lehet, hogy a jól megszerkesztett webshop egyfajta alapelvárásként jelentik meg a vásárlókban. Szignifikáns hatással a különböző szegmensekben az egyéb faktorok bírnak, úgymint a tényleges vásárlás lebonyolítása, a fizetés, az ügyfélszolgálat elérhetősége és a vele folytatott kommunikáció. Ezek hatása és relevanciája azonban eltérő. A megrendelési és a kiszállítási folyamat az offline-termékek és szolgáltatások esetében releváns dimenzió, tehát azokban az esetekben, amikor a vásárlás megvalósítása offline is történhet. Az e-termékek és -szolgáltatások esetében a biztonság dimenziója bír releváns, pozitív hatással az elégedettség alakulására, ami nem meglepő, hisz a teljes folyamat, gyakran még a termékek elfogyasztása is az online világban történik, így sokkal jelentősebb a személyes adatok védelme és ennek hatása az elégedettségre. Megállapítható, hogy azokban az esetekben, amikor a vásárolt terméket, szolgáltatást nem tudjuk ténylegesen a kezünkbe fogni, nagyobb fontossággal bír a webshophoz köthető észlelt biztonság. Az ügyfélszolgálat dimenziója az offline-termékek és az eszolgáltatások esetében releváns. 
Kutatásunk elsődleges célcsoportja, vagyis a teljes tapasztalattal rendelkező válaszadók esetében általánosságban megállapítható, hogy a termékekhez kapcsoló továbbajánlási szándék mindig magasabb. Az offline és az online szállítási módok közül is mindig az offline módok esetében magasabb az érték. Szignifikáns különbség azonban csak a két szélsőérték (offline-termékek, e-szolgáltatások) esetében figyelhető meg. Ezzel szemben az elégedettség és az újravásárlási szándék közötti útegyüttható offline esetben magasabb, tehát az elégedettségi szint hatása az újravásárlási szándékra az online jószágok esetében kisebb. Ezek az eredmények azonban eltérést mutathatnak az első és az újravásárlók esetében, melynek részleteire a kísérleti kutatás mutat rá. Ez alapján a vásárlók viselkedési szándékának elörejelzésekor figyelembe kell venni azt is, hogy milyen régóta ügyfelei a webshopnak.

Az elmélet számára nem csak a hipotézisvizsgálatunk eredményei nyújtanak új információkat, hanem az alkalmazott módszertan is újszerü: a nagymintás kutatási eredményeink validálására, illetve továbbfejlesztésére egy kísérletet valósítottunk meg, mely módszer az elmúlt években vált a marketing kedvelt kutatási eszközévé (Baum Spann, 2011).

\subsection{A kutatás korlátai és a jövőbeni kutatási irányok}

Jelen tanulmányban egy nagymintás, 1.000 fős kérdőíves kutatás, valamint egy 100 fős, hallgatói kísérlet eredményeit mutattuk be. Kísérletünket úgy terveztük meg, hogy kiküszöböljük a nagymintás kutatásunk limitációit, vagyis hogy a megkérdezettek különböző honlapokat értékeltek, valamint hogy nem tudtuk a tapasztalati szintjük alapján megkülönböztetni őket. A kísérletből származó eredmények több eltérésre is felhívják a figyelmet, azonban ezek validálására egy további nagymintás kutatásra lenne szükség, melynek során tényleges vásárlási szituációkat tudnak a megkérdezettek értékelni ugyanazt a honlapot felhasználva. Mindemellett a kísérlet során a fizetéshez kapcsolódó tevékenységek szimulálása is korlátozottan állt a rendelkezésünkre. További limitáció, hogy jelen tanulmány jellemzően a probléma kvantitatív megközelítéséből, a statisztikai módszerek alkalmazásából indult ki, és a kvalitatív elemzések csak érintőlegesen jelentek meg a kísérletben. Amennyiben célul tűzzük ki a felvázolt különbségek közötti magyarázatok mélyebb, kvalitatív jellegü megértését is, akkor szükséges további feltáró, kvalitatív interjúk megvalósítása. 
Kutatásunk során elkülönítve vizsgáltuk az offline-termékek, az e-termékek, az offlineszolgáltatások és az e-szolgáltatások piacát, és e feltételezett modellben valóban megfigyelhetőek eltérések. Ebből kiindulva a jövőben érdemes lenne további szempontok szerinti csoportokban is megvizsgálni a kapcsolatrendszer alakulását, például ár szerinti csoportosításban (alacsony és magas költések), különböző vásárlói szegmensekben (kényelemorientáltak, információgyüjtők), vagy akár az involvement alapján. További jövőbeli kutatási irányként fontosnak tartjuk megjelölni a tanulmányunk során bemutatott modellek kiterjesztését más típusú honlapokra is (pl. csupán információnyújtásra szolgáló vagy a márkát erősítő honlapokra), valamint célszerü lenne az egyes szektorokra specializálódva is megvizsgálni a témát (például bankok, idegenforgalmi cégek). Ugyancsak érdemes lenne górcső alá venni a biztonsággal kapcsolatos információhiányok miértjét, illetve ennek hatását az elvárásokra, értékelésekre. 


\section{HIVATKOZOTT IRODALOM}

Adam, S. 2002. A model of Web use in direct and onlinemarketing strategy. Electronic Markets 12, 1-8., dx.doi.org/10.1080/101967802762553521

Agárdi, I., 2004. Horizontális stratégiai szövetségek hatása a kiskereskedelmi vállalatok marketingstratégiájára és teljesítményére az élelmiszer- és napi cikk kiskereskedelemben. Ph.D. értekezés, Budapesti Corvinus Egyetem.,

Ajzen, I., Fishbein, M., 1972. Attitudes and Normative Beliefs as Factors Influencing Behavioral Intentions. Journal of Personality and Social Psychology., dx.doi.org/10.1037/h0031930

Akinci, S., Atilgan-Inan, E., Aksoy, S., 2010. Re-assessment of E-S-Qual and E-RecSQual in a pure service setting. Journal of Business Research 63, 232-240., dx.doi.org/10.1016/j.jbusres.2009.02.018

Anderson, E.W., Sullivan, M.W., 1993. The antecedents and consequences of customer satisfaction for firms. Marketing Science 12, 125-143., http://dx.doi.org/10.1287/mksc.12.2.125

Anderson, R.E., 1973. Consumer Dissatisfaction: The Effect of Disconfirmed Expectancy on Perceived Product Performance. Journal of Marketing Research (JMR) 10, 38-44., http://www.jstor.org/stable/3149407

Anderson, R.E., Srinivasan, S.S., 2003. E-Satisfaction and E-Loyalty: A Contingency Framework. Psychology \& Marketing 20, 123-138., dx.doi.org/10.1002/mar.10063

Andrási, G., 2011. A hazai online kereskedelem. In: Bányai Edit, Novák Péter (szerk): Online üzlet és marketing. Budapest: Akadémiai Kiadó.,

Babakus, E., Boller, G.W., 1992. An Empirical Assessment of the SERVQUAL Scale. Journal of Business Research 24, 253-268., dx.doi.org/10.1016/0148-2963(92)90022-4

Babin, B.J., Griffin, M., Babin, L., 1994. The Effect of Motivation to Process on Consumers' Satisfaction Reactions. Advances in Consumer Research 21, 406-411., http://acrwebsite.org/volumes/7626/volumes/v21/NA-21

Barnes, S.I., Vidgen, R., 2001. An Evaluation of Cyber-Bookshops: The WebQual Method. International Journal of Electronic Commerce 6, 11., dx.doi.org/10.1080/10864415.2001.11044225

Barnes, S.J., Liu, K., Vidgen, R.T., 2002. Evaluating wap news sites:the webqualm approach. The 9th European Conference on Information Systems, Bled.

Barnes, S.J., Vidgen, R., 2003. Measuring Web site quality improvements: a case study of the forum on strategic management knowledge exchange., http://dx.doi.org/10.1108/02635570310477352

Barnes, S.J., Vidgen, R.T., 2000. WebQual:An Exploration of Web-site Quality. http://www.webqual.co.uk/papers.htm (letöltve: 2011. november 20.),

Barnes, S.J., Vidgen, R.T., 2006. Data triangulation and web quality metrics: A case study in e-government. Information \& Management 43, 767-777., dx.doi.org/10.1016/j.im.2006.06.001

Bauer, H.H., Falk, T., Hammerschmidt, M., 2006. eTransQual: A transaction processbased approach for capturing service quality in online shopping. Journal of Business Research 59, 866-875., dx.doi.org/10.1016/j.jbusres.2006.01.021 
Baum - Spann, 2011. Experimente im Marketing_Entwicklung und zukünftige Chancen. Marketing - Zeitschrift für Forschung und Praxis.

Bellman, S., Lohse, G.L., Johnson, E.J., 1999. Predictors of Online Buying Behavior. Communications of the ACM 42, 32-38., dx.doi.org/10.1145/322796.322805

Bernoff, J., Li, C., 2008. Harnessing the Power of the Oh-So-Social Web. MIT Sloan Management Review 49, 36-42.,

Berry, L.L., Seiders, K., Grewal, D., 2002. Understanding Service Convenience. Journal of Marketing 66, 1-17., http://www.inforesearching.com/downloads/oh-so-socialweb.pdf

Bhattacherjee, A., 2001. Understanding information systems continuance: an expectation-confirmation model. MIS Quarterly 25, 351-370., http://www.jstor.org/stable/3250921

Bolton, R.N., Drew, J.H., 1991. A Multistage Model of Customers' Assessments of Service Quality and Value. Journal of Consumer Research 17, 375-384., http://www.jstor.org/stable/2626833

Brady, M.K., Robertson, C.J., 2001. Searching for a consensus on the antecedent role of service quality and satisfaction: an exploratory cross-national study. Journal of Business Research 51, 53-60., dx.doi.org/10.1016/S0148-2963(99)00041-7

Bressoles, G., Nantel, J., 2004. Electronic Service Quality: A comparison of three measueremnt scales. Proceedings of 33th EMAC Conference, Murcia (Spain).,

Bressolles, G., Durrieu, F., Giraud, M., 2007. The impact of electronic service quality's dimensions on customer satisfaction and buying impulse. Journal of Customer Behaviour 6, 37-56., dx.doi.org/10.1362/147539207X198365

Browne, M.W., Cudeck, R., 1992. Alternative Ways of Assessing Model Fit. Sociological Methods \& Research 21, 230., dx.doi.org/10.1177/0049124192021002005

Burke, Raymond R. (1997). Real shopping in virtual stores. In Stephen P. Bradley and Richard L. Nolan (Eds.), Sense and respond: Capturing the value in the network era. Boston, MA: Harvard Business School.

Cao, X., 2012. The Relationships between E-Shopping and Store Shopping in the Shopping Process of Search Goods. Transportation Research: Part A: Policy and Practice 46, 993-1002., dx.doi.org/10.1016/j.tra.2012.04.007

Carlson, J., O'Cass, A., 2011. Developing a framework for understanding e-service quality, its antecedents, consequences, and mediators. Managing Service Quality 21, 264-286.,

Carlson, J., O'Cass, A., 2010. Exploring the relationships between e-service quality, satisfaction, attitudes and behaviours in content-driven e-service web sites. Journal of Services Marketing 24, 112 - 127., dx.doi.org/10.1108/09604521111127965

Carman, J.M., 1990. Consumer Perceptions of Service Quality: An Assessment of the SERVQUAL Dimensions. Journal of Retailing 66, 33., dx.doi.org/10.1108/08876041011031091

Castañeda, J., 2011. Relationship Between Customer Satisfaction and Loyalty on the Internet. Journal of Business \& Psychology 26, 371-383., dx.doi.org/10.1007/s10869010-9196-z\#page-1 
Chaffey, D., Ellis-Chadwick, F., Johnston, K., Mayer, R., 2006. Internet Marketing: Strategy, Implementation and Practice (3rd Edition). Harlow: Pearson Education Limited.,

Cheema, A., Papatla, P., 2010. Relative importance of online versus offline information for Internet purchases: Product category and Internet experience effects. Journal of Business Research 63, 979-985., dx.doi.org/10.1016/j.jbusres.2009.01.021

Chen, W. Ch., Cheng, Ch.Y., 2012. How online and offline behavior processes affect each other: customer behavior in a cyber-enhanced bookstore. Qual - Quant, Springer.,

Childers, T.L., Carr, C.L., Peck, J., Carson, S., 2001. Hedonic and utilitarian motivations for online retail shopping behavior. Journal of Retailing 77, 511., dx.doi.org/10.1016/S0022-4359(01)00056-2

Chinkán, A., Czakó, E., Zoltayné Paprika, Z. 2002. Vállalati versenyképesség a globalizálódó magyar gazdaságban, Budapest: Akadémiai Kiadó.,

Chow, S., Holden, R., 1997. Toward an understanding of loyalty: The moderating role of trust. Journal of Managerial Issues 9, 275., http://www.jstor.org/stable/40604148

Christodoulides, G., Michaelidou, N., 2011. Shopping motives as antecedents of esatisfaction and e-loyalty. Journal of Marketing Management 27, 181-197., dx.doi.org/10.1080/0267257X.2010.489815

Churchill Jr., G.A., Surprenant, C., 1982. An Investigation Into the Determinants of Customer Satisfaction. Journal of Marketing Research (JMR) 19, 491-504.,

Clark, B.H., 1997. Welcome to My Parlor... Marketing Management 5, 10-25.,

Cohen, J.B., Goldberg, M.E., 1970. The Dissonance Model in Post-Decision Product Evaluation. Journal of Marketing Research (JMR) 7, 315-321.,

Consumer Behavior Fourth Edition., 1982. . Marketing News 15, 4-4.,

Cronin Jr., J.J., Brady, M.K., Hult, G.T.M., 2000. Assessing the Effects of Quality, Value, and Customer Satisfaction on Consumer Behavioral Intentions in Service Environments. Journal of Retailing 76, 193., dx.doi.org/10.1016/S0022-4359(00)00028-2

Cronin Jr., J.J., Taylor, S.A., 1992. Measuring Service Quality: A Reexamination and Extension. Journal of Marketing 56, 55-68., http://www.jstor.org/stable/1252296

Cronin Jr., J.J., Taylor, S.A., 1994. SERVPERF Versus SERVQUAL: Reconciling Performance-Based and Perceptions-Minus-Expectations Measurement of Service Quality. Journal of Marketing 58, 125-131., http://www.jstor.org/stable/1252256

Csikszentmihalyi, M., 1988. The Social Life of Things: Commodities in Cultural Perspective (Book). Contemporary Sociology 17, 223-224.,

Davis, F.D., 1989. Perceived Usefulness, Perceived Ease of Use, and User Acceptance of Information Technology. MIS Quarterly 13, 319-340., http://www.jstor.org/stable/249008

Davis, F.D., Bagozzi, R.P., Warshaw, P.R., 1989. User acceptance of computer technology: a comparison of two theoretical models. Management Science 35, 9821003., dx.doi.org/10.1287/mnsc.35.8.982

Day, G.S., 1969. A Two-Dimensional Concept Of Brand Loyalty. Journal of Advertising Research 9, 29-35.,

Day, R.L, 1977. Extending the concept of consumer satisaction. Advances in Consumer Research, 149-154., http://acrwebsite.org/volumes/9346/volumes/v04/NA-04 
De Ruyter, K., Bloemer, J., Peeters, P., 1997. Merging Service Quality and Service Satisfaction: An Empirical Test of an Integrative Model. Journal of Economic Psychology 18, 387-406., dx.doi.org/10.1016/S0167-4870(97)00014-7

Demeter, K., 2009. Szolgáltatások versenyképességének elemzése vállalati példák alapján”, Magyar Minőség, 18, 6-18.,

Dick, A.S., Basu, K., 1994. Customer Loyalty: Toward an Integrated Conceptual Framework. Journal of the Academy of Marketing Science 22, 99-113., dx.doi.org/10.1177/0092070394222001

Dörnyei, K., Gyulavári, T., 2012. A márkalojalitást befolyásoló tényezők vizsgálata: az involvement, a kockázat és az észlelt tudás szerepe. Corvinus Marketing Tanulmányok 1, $1-25$,

Dr. Rekettye, G., dr. Hetesi, E., 2009. Fogyasztói elégedettségi mérések. Http://www.fvszemle.hu/archivum/2009_decemberi_szam/gazdasag_fogyaszto/fogyasz toi_elegedettsegi_meresek/ (letöltve: 2011 . március 10 .),

Drozd, F., Lehto, T., Oinas-Kukkonen, H., 2012. Exploring Perceived Persuasiveness of a Behavior Change Support System: A Structural Model M. Bang and E.L. Ragnemalm (Eds.): PERSUASIVE 2012, LNCS 7284, 157-168., dx.doi.org/10.1007/978-3-64231037-9_14\#page-1

Drury, D.H., Farhoomand, A., 1996. Administrative innovation applied to systems adoption. International Journal of Technology Management 12, 45., dx.doi.org/10.1504/IJTM.1996.025479

Eastlick, M.A., Feinberg, R.A., 1999. Shopping Motives for Mail Catalog Shopping. Journal of Business Research 45, 281-290., dx.doi.org/10.1016/S0148-2963(97)00240-3

Eighmey, J., 1997. Profiling user responses to commercial web sites. Journal of Advertising Research 37, 59-66.,

Enet, 2011. Tavaly is szárnyalt a magyarországi e-kereskedelem. http://gkienet.hu/hu/hirek/tavaly-is-szarnyalt-a-magyarorszagi-e-kereskedelem/ (letöltve: 2011. szeptember 16.),

Enet, 2012. E-kereskedelmi trendek 2011-ben. http://gkienet.hu/hu/hirek/ekereskedelmi-trendek-2011-ben/ (letöltve 2012. január 12.),

Eszes, I., Bányai, E., 2002. Online m@erketing. Budapest: Műszaki Kvk.,

EUROSTAT statisztikák. http://epp.eurostat.ec.europa.eu/portal/page/portal/statistics (2011, 2012),

Evans, J.R., Laskin, R.L., 1994. The Relationship Marketing Process: Conceptualization and Application. Industrial Marketing Management 23, 439-452., dx.doi.org/10.1016/0019-8501(94)90007-8

Evanschitzky, H., Iyer, G.R., Hessea, J., Ahlerta, D., 2004. E-satisfaction: a reexamination. Journal of Retailing 80, 239-247., dx.doi.org/10.1016/j.jretai.2004.08.002

Fassnacht, M., Köse, I., 2007. Consequences of Web-based service quality: Uncovering a multi-faceted chain of effects. Journal of Interactive Marketing (John Wiley \& Sons) 21, 35-54., dx.doi.org/10.1002/dir.20084

Fearon, C., Philip, G., 2008. Measuring success of electronic trading in the insurance industry: operationalising the disconfirmation of expectations paradigm. Behaviour \& Information Technology 27, 483-493., dx.doi.org/10.1080/01449290601177029 
Folkes, V.S., 1984. Consumer Reactions to Product Failure: An Attributional Approach. Journal of Consumer Research 10, 398-409.,

Fornell, C., Larcker, D.F.,1981. Evaluating Structural Equation Models with Unobservable Variables and Measurement Error. Journal of Marketing Research 18, 3950 .,

Fornell, C., 1992. A National Customer Satisfaction Barometer: The Swedish Experience. Journal of Marketing 56, 6-21.,

Fournier, S., Mick, D.G., 1999. Rediscovering Satisfaction. Journal of Marketing 63, 523.,

Francis, J.E, 2007. Internet retailing quality: one size does not fit all. Managing Service Quality 17, 341-355., dx.doi.org/10.1108/09604520710744335

Francis, J.E., 2009. Category-specific RECIPEs for internet retailing quality. Journal of Services Marketing 23, 450-461., dx.doi.org/10.1108/08876040910995248

Francis, J.E., White, L., 2002. Exploratory and confirmatory factor analysis of the Perceived Internet Retailing Quality (PIRQUAL) model. ANZMAC Conference Proceedings., http://www.anzmac.org/conference_archive/2002/papers/pdfs/p208_francis.pdf

Francis, J.E., White, L., 2002. Pirqual: a scale for measuring customer expectations and perceptions of quality in internet retailing. Presented at the AMA Winter Educators' Conference Proceedings, p. 263.,

Francis, J.E., White, L., 2003. Utilitarian and hedonic value across fulfillmentproduct categories of Internet shopping. AMA ServSIG Services Research Conference 2003 Chicago: American Marketing Association.,

Francis, J.E., White, L., 2004. Value across fulfillment-product categories of Internet shopping. Managing Service Quality 14, 226-234.,

Fu-Ling Hu, Chao Chao Chuang, 2012. A study of the relationship between the value perception and loyalty intention toward an e-retailer website. Journal of Internet Banking \& Commerce 17, 1-18.,

Füstös, L.. 2009. A sokváltozós adatelemzés módszerei. MTA Szociológiai Kutatóintézete, Társadalomtudományi elemzések Akadémiai Műhelye.,

Gagliano, K.B., 1994. Customer Expectations and Perceptions of Service Quality in Retail Apparel Specialty Stores. Journal of Services Marketing 8, 60.,

Gáti, M., Kolos, K., 2012. Az elektronikus kereskedelem alkalmazása a hazai vállalatok körében : A piacorientáció és a marketingkörnyezet szerepe. Vezetéstudomány 43, 9096.,

Gefen, D., 2002. Customer loyalty in e-commerce. Journal of the association for information systems 3, 27-51.,

Godwin, U.J., Bagchi, K.K., Kirs, P.J., 2010. An assessment of customers' e-service quality perception, satisfaction and intention. International Journal of Information Management 30, 481-492., dx.doi.org/10.1016/j.ijinfomgt.2010.03.005

Gommans, M., Krishman, K.S., Scheffold, K.B., 2001. From Brand Loyalty to E-Loyalty: A Conceptual Framework. Journal of Economic \& Social Research 3, 43.,

Goode, M.M.H., Harris, L.C., 2007. Online behavioural intentions: an empirical investigation of antecedents and moderators. European Journal of Marketing 41, 512536 , 
Goodwin, C., Ross, I., 1992. Consumer Responses to Service Failures: Influence of Procedural and Interactional Fairness Perceptions. Journal of Business Research 25, 149163.,

Gronroos, C., Heinonen, F., Isoniemi, K., Lindholm, M., 2000. The NetOffer model: a case example from the virtual marketspace. Management Decision 38, 243., dx.doi.org/10.1108/00251740010326252

Gyulavári, T., 2005. Fogyasztói árelfogadás az interneten. Ph.D. értekezés. Budapesti Corvinus Egyetem.,

Ha, S., Stoel, L., 2012. Online apparel retailing: roles of e-shopping quality and experiential e-shopping motives. Journal of Service Management 23, 197-215., dx.doi.org/10.1108/09564231211226114

Heidt, T., Ponirin, P., 2011. Modelling the Complexity of e-Loyalty: The Role of e-Value, e-Trust, e-Satisfaction, and e-Commitment. Conference Paper.,

Helson, H., 1948. Adaptation-level as a basis for a quantitative theory of frames of reference. Psychological Review 55, 297-313.,

Hennig-Thurau, T., Gwinner, K.P., Gremler, D.D., 2002. Understanding Relationship Marketing Outcomes: An Integration of Relational Benefits and Relationship Quality. Journal of Service Research 4, 230., dx.doi.org/10.1177/1094670502004003006

Henseler, J. 2010. On the convergence of the partial least squares path modeling algorithm. Comput Stat, Springer, 107-120., dx.doi.org/10.1007/s00180-009-0164$\mathrm{x} \#$ page-1

Henseler, J., Chin, W.W., 2010. A Comparison of Approaches for the Analysis of Interaction Effects between Latent Variables Using Partial Least Squares Path Modeling. Structural Equation Modeling: A Multidisciplinary Journal 17, 82-109., dx.doi.org/10.1080/10705510903439003

Henseler, J., Ringle, C.M, Sinkovics, R.R., 2009. The use of partial least squares path modeling in international marketing. Advances in International Marketing 20, 277-319. , dx.doi.org/10.1108/S1474-7979(2009)0000020014

Herring, S.C., Scheidt, L.A., Wright, E., Bonus, S., 2005. Weblogs as a bridging genre. Information Technology \& People 18, 142-171., dx.doi.org/10.1108/09593840510601513

Hill, D.J., 1986. Satisfaction and consumer services. Advances in Consumer Research 13, 311-315.,

Hirschman, E.C., Holbrook, M.B., 1982. Hedonic Consumption: Emerging Concepts, Methods and Propositions. Journal of Marketing 46, 92-101.,

Hoch, S.J., Bradlow, E.T., Wansink, B., 1999. The Variety of an Assortment. Marketing Science 18, 527-546., dx.doi.org/10.1287/mksc.18.4.527

Hoffman, D.L., Novak, T.P., 1996. Marketing in hypermedia computer-mediated environments: Conceptual foundations. Journal of Marketing 60, 50.,

Hoffman, D.L., Novak, T.P., 2000. How to acquire customers on the Web. Harvard Business Review 78, 179.,

Hofmeister-Tóth, Á., 2008. A fogyasztói magatartás alapjai : Vásárlási döntés, fogyasztási minták, életstílus. Budapest: Aula Kiadó.,

Hofmeister-Tóth, Á., Simon, J., Sajtos, L., 2003. Fogyasztói elégedettségmérés. Budapest: Alinea Kiadó., 
Hong-Youl Ha, Muthaly, S.K., Akamavi, R.K., 2010. Alternative explanations of online repurchasing behavioral intentions: A comparison study of Korean and UK young customers. European Journal of Marketing 44, 874-904., dx.doi.org/10.1108/03090561011032757

Hsin Hsin Chang, Yao-Hua Wang, Wen-Ying Yang, 2009. The impact of e-service quality, customer satisfaction and loyalty on e-marketing: Moderating effect of perceived value. Total Quality Management \& Business Excellence 20, 423-443., dx.doi.org/10.1080/14783360902781923

Hsu, Ch.L., Wu, C.Ch., Chen, M.Ch., 2012. An empirical analysis of the antecedents of e-satisfaction and e-loyalty_focusing on the role of flow and its antecedents. Information Systsem and E-Business Management, Springer., dx.doi.org/10.1007/s10257-012-01948

Hu, L., Bentler, P.M., 1999. Cutoff Criteria for Fit Indexes in Covariance Structure Analysis: Conventional Criteria versus New Alternatives. Structural Equation Modeling 6, 1-55., dx.doi.org/10.1080/10705519909540118

Hunt, H.K., 1977. Overview and future research direction". in Hunt (ed.), Conceptualization and measurement of consumer satisfaction and dissatisfaction, Cambridge: Marketing science institute, 92-119.,

Jacoby, J., Chestnut, R.W., Fisher, W.A., 1978. A Behavioral Process Approach to Information Acquisition in Nondurable Purchasing. Journal of Marketing Research (JMR) 15, 532-544., dx.doi.org/10.2307/3150623

Janda, S., Trocchia, P.J., Gwinner, K.P., 2002. Consumer perceptions of Internet retail service quality. International Journal of Service Industry Management 13, 412., dx.doi.org/10.1108/09564230210447913

Jayawardhena, C., 2004. Measurement of Service Quality in Internet Banking: The Development of an Instrument. Journal of Marketing Management 20, 185-207., dx.doi.org/10.1362/026725704773041177

Jessica Santos, 2003. E-service quality: a model of virtual service quality dimensions. Managing Service Quality 13, 233-246., dx.doi.org/10.1108/09604520310476490

Johnson, M.D._e. al., 2001. The Evolution and Future of National Customer Satisfaction Index Modēls. Journal of Economic Psychology 22, 217-245., dx.doi.org/10.1016/S0167-4870(01)00030-7

Johnson, M.D., Fornell, C., 1991. A Framework for Comparing Customer Satisfaction across Individuals and Product Categories. Journal of Economic Psychology 12, 267286., dx.doi.org/10.1016/0167-4870(91)90016-M

Józsa. L., Ercsey, I., 2005. The role of marketing in the management of the public utility service quality, IV. International Congress of Public and non Profit Marketing, University of Cadiz, pp. 377-386.,

Kanji, G.K., 2002. Business excellence: make it happen. Total Quality Management 13, 1115., dx.doi.org/10.1080/09544120200000007

Kápolnai, A., Nemeslaki, A., Pataki, R., 2002. E-business stratégia vállalati felsővezetőknek. Budapest: Aula Kiadó.,

Kenesei, Zs., 2000. Vertikális marketingkapcsolatok elemzése és mérése a kereskedelmi banki tevékenységben. Ph.D értekezés. Budapesti Corvinus Egyetem., 
Kenesei, Zs., Kolos, K., 2007. Szolgáltatásmarketing és -menedzsment. Budapest: Alinea Kiadó.,

Kenesei, Zs., Kolos, K., 2008. A hatékony panaszkezelés lehetőségei: kompenzáció és bocsánatkérés. Vezetéstudomány 5, 27-39.,

Kim, D.J., 2012. An investigation of the effect of online consumer trust on expectation, satisfaction, and post-expectation. Information Systsem and E-Business Management, Springer., dx.doi.org/10.1007/s10257-010-0136-2

Kim, H.-R., 2005. Developing an index of online customer satisfaction. Journal of Financial Services Marketing 10, 49-64., dx.doi.org/10.1057/palgrave.fsm.4770173

Kim, M., Stoel, L., 2005. Salesperson roles: are online retailers meeting customer expectations? International Journal of Retail \& Distribution Management 33, 284-297., dx.doi.org/10.1108/09590550510593211

Know, W., Lennon, S.J., 2009. What includes online loyalty? Online versus offline brand images. Journal of Business Research 62, 557-564., dx.doi.org/10.1016/j.jbusres.2008.06.015

Kotler, Ph., Keller, K. L., 2008. Marketingmenedzsment. Budapest: Akadémiai Kiadó.,

Kuehn, A.A., Day, R.L., 1962. Strategy of Product Quality. Harvard Business Review 40, 100-110.,

Kumar, A., Oliver, R.L., 1997. Cognitive Appraisals, Consumer Emotions, and Consumer Response. Presented at the Advances in Consumer Research, Association for Consumer Research, pp. 17-18.,

Ladhari, R., 2010. Developing e-service quality scales: A literature review. Journal of Retailing \& Consumer Services 17, 464-477., dx.doi.org/10.1016/j.jretconser.2010.06.003

LaTour, S.A., Peat, N.C., 1979. Conceptual and methodological issues in consumer satisfaction research. Advances in Consumer Research 6, 431-437.,

Lennon, R., Harris, J., 2002. Customer service on the Web: A cross-industry investigation. Journal of Targeting, Measurement \& Analysis for Marketing 10, 325. dx.doi.org/10.1057/palgrave.jt.5740057

Limayem, M., Khalifa, M., 2000. What Makes Consumers Buy from Internet? A Longitudinal Study of Online Shopping. IEEE Transactions on Systems, Man \& Cybernetics: Part A 30, 421., dx.doi.org/10.1109/3468.852436

Lin, C.S., Wu, S., 2002. Exploring the Impact of Online Service Quality on Portal Site Usage. Proceedings of the 35th Hawaii International Conference on System Sciences., dx.doi.org/10.1109/HICSS.2002.994223

Liu, C., Arnett, K. P. 2000. Exploring the factors associated with web site success in the context of electronic commerce. Information\&management, 38, 23-33. , dx.doi.org/10.1016/S0378-7206(00)00049-5

Liu, X., Zeng, X., Xu, Y., Koehl, L., 2008. A fuzzy model of customer satisfaction index in e-commerce. Mathematics \& Computers in Simulation 77, 512-521., dx.doi.org/10.1016/j.matcom.2007.11.017

Lohse, G.L., Bellman, S., 2000. Consumer buying behavior on the Internet: Findings from panel data. Journal of Interactive Marketing (John Wiley \& Sons) 14, 15-29., dx.doi.org/10.1002/(SICI)1520-6653(200024)14:1<15::AID-DIR2>3.0.CO;2-C 
Loiacono, E.T., Watson, R.T., Goodhue, D.L., 2002. Webqual: a measure of website quality. Presented at the AMA Winter Educators' Conference Proceedings, p. 432.,

Loiacono, E.T., Watson, R.T., Goodhue, D.L., 2007. WebQual: An Instrument for Consumer Evaluation of Web Sites. International Journal of Electronic Commerce 11, 51-87.,

Long, M., McMellon, C., 2004. Exploring the determinants of retail service quality on the Internet. Journal of Services Marketing 18, 78-90., dx.doi.org/10.1108/08876040410520726

Ltifi, M., Gharbi, J.-E., 2012a. E-satisfaction and e-loyalty of consumers shopping online. Journal of Internet Banking \& Commerce 17, 1-20.,

Ltifi, M., Gharbi, j.-e., 2012b. The impact of electronic services on e-trust in the Tunisian post. Interdisciplinary Journal of Contemporary Research in Business 3, 449-468.,

Lu, J., Wang. L., Hayes, L.A., 2012. How do technology readiness, platform functionality and trust influence $\mathrm{c} 2 \mathrm{c}$ user satisfaction. Journal of Electronic Commerce Research 13, 50-69.,

Lynch Jr., J.G., Ariely, D., 2000. Wine Online: Search Costs Affect Competition on Price, Quality, and Distribution. Marketing Science 19, 83., dx.doi.org/10.1287/mksc.19.1.83.15183

Malhotra, Naresh K., Simon Judit, Marketingkutatás. Budapest: Akadémiai Kiadó, 2009.,

Martín, S.S., Camarero, C., José, R.S., 2011. Does involvement matter in online shopping satisfaction and trust? Psychology \& Marketing 28, 145-167., dx.doi.org/10.1002/mar.20384

McDougall, G.H.G., Levesque, T., 2000. Customer satisfaction with services: putting perceived value into the equation. Journal of Services Marketing 14, 392., dx.doi.org/10.1108/08876040010340937

Menon, S., Kahn, B.E., 2002. Cross-category effects of induced arousal and pleasure on the Internet shopping experience. Journal of Retailing 78, 4-5., dx.doi.org/10.1016/S0022-4359(01)00064-1

Meuter, M.L., Ostrom, A.L., Roundtree, R.I., Bitner, M.J., 2000. Self-Service Technologies: Understanding Customer Satisfaction with Technology-Based Service Encounters. Journal of Marketing 64, 50-64., dx.doi.org/10.1509/jmkg.64.3.50.18024

Minjeong Kim, Jung-Hwan Kim, Sharron J. Lennon, 2006. Online service attributes available on apparel retail web sites: an E-S-QUAL approach. Managing Service Quality 16, 51-77., dx.doi.org/10.1108/09604520610639964

Minocha, S., Dawson, L. H., Blandford, A., Millard, N., 2005. Providing value to customer in e-commerce environments: the customer's perspective. Preprint: chapter to appear in contemporary research in e-Marketing, 2.,

Minocha, S., Millard, N., Dawson, L.H., 2003. Integrating Customer Relationship Management Strategies in (B2C) E-Commerce Environments. Human-Computer Interaction, 335 - 342.,

Modahl, M., 2000. Now or Never: How Companies Must Change Today to Win the Battle for Internet Consumers. CMA Management 74, 6.,

Montoya-Weiss, M.M., Voss, G.B., Grewal, D., 2000. Bricks to clicks: what drives consumer use of the internet in a multichannel retail environment? Presented at the AMA Winter Educators' Conference Proceedings, p. 347., 
Moon, S.-Y., Philip, G.C., Moon, S., 2011. The Effects of Involvement on E-Satisfaction Models. Services Marketing Quarterly 32, 332-342., dx.doi.org/10.1080/15332969.2011.606764

Móricz, P., 2009. Élenjáró magyarországi internetes vállalkozások fejlődése az üzleti modell nézőpontjából. Ph.D. értekezés, Budapesti Corvinus Egyetem.,

Nath, A.K., Singh, R., 2010. Evaluating the Performance and Quality of Web Services in Electronic Marketplaces. e-Service Journal 7, 43-59.,

Nemeslaki, A., Duma, L., Szántai, T., 2004. E-business üzleti modellek. Budapest: Adecom.,

Nemeslaki, A., 2012. Vállalati internetstratégia. 4. fejezet. Budapest: Akadémiai Kiadó.,

Neumann - Bódi, E., 2012. Vevőértékelés egyéni és szervezeti vásárlók esetében. Az ajánlással szerzett ügyfelek jellemzői és hatásuk a vevőértékre szervezetközi viszonylatban. Ph.D. értekezés. Budapesti Corvinus Egyetem.,

Neumann - Bódi, E., 2013. Az ügyfélszerzési Mód hatásának vizsgálata a vevőelégedettségre és a lojalitásra a szervezeti piacon. Az ajánlás hatásának vizsgálata strukturális modellezés segítségével. Vezetéstudomány 44, 29 - 44.,

Nirmalya, B., Jayashree, D., Harsh, P., 2012. Paradigms of Satisfaction Research: A Conceptual Foundation. Advances In Management 5, 17 - 20.,

Nitse, P.S., Parker, K.R., Krumwiede, D., Ottaway, T., 2004. The impact of color in the e-commerce marketing of fashions: an exploratory study. European Journal of Marketing 38, 898-915., dx.doi.org/10.1108/03090560410539311

Novak, T.P., Hoffman, D.L., Yiu-Fai Yung, 2000. Measuring the Customer Experience in Online Environments: A Structural Modeling Approach. Marketing Science 19, 22. dx.doi.org/10.1287/mksc.19.1.22.15184

NRC Piackutató Kft. 2009. E-Commerce Trend Report 2009- lakossági kutatás. http://nrc.hu/termekek/ecommerce (letöltve: 2011. szeptember 25.),

NRC Piackutató Kft. 2012. Internet-riport 2011/Q3. http://nrc.hu/hirek/2012/01/13/Internetpenetracio (letöltve: 2013. április 25.),

Nunnaly, J.C., Bernstein, I.H., 1994. Psychometric Theory, .New York: McGraw-Hill.,

Nyírő, N., 2011. Médiatechnológiai innovációk elfogadása és terjedése. Ph.D. értekezés. Budapesti Corvinus Egyetem.,

Oliver, R.L., 1977. Effect of Expectation and Discontinuation on Postexposure Product Evaluations: An Alternative Interpretation. Journal of Applied Psychology 62, 480-486.,

Oliver, R.L., 1980. A Cognitive Model of the Antecedents and Consequences of Satisfaction Decisions. Journal of Marketing Research (JMR) 17, 460-469., dx.doi.org/10.2307/3150499

Oliver, R.L., 1993. Cognitive, Affective, and Attribute Bases of the Satisfaction Response. Journal of Consumer Research 20, 418-430., dx.doi.org/10.2307/2489356

Oliver, R.L., 1999. Whence Consumer Loyalty? Journal of Marketing 63, 33-44., dx.doi.org/10.2307/1252099

Oliver, R.L., DeSarbo, W.S., 1988. Response Determinants in Satisfaction Judgments. Journal of Consumer Research 14, 495-507., dx.doi.org/10.2307/2489156

Oliver, R.L., Linda, G., 1981. Effect of satisfaction and its antecedents on consumer preference and intention. Advances in Consumer Research 8, 88-93., 
Oliver, R.L., Rust, R.T., 1997. Customer Delight: Foundations, Findings, and Managerial Insight. Journal of Retailing 73, 311-336., dx.doi.org/10.1016/S0022-4359(97)90021-X

Olsen, S.O., 2002. Comparative Evaluation and the Relationship Between Quality, Satisfaction, and Repurchase Loyalty. Journal of the Academy of Marketing Science 30, 240-249., dx.doi.org/10.1177/0092070302303005

Olshavsky, R.W., Miller, J.A., 1972. Consumer Expectations, Product Performance, and Perceived Product Quality. Journal of Marketing Research (JMR) 9, 19-21., dx.doi.org/10.2307/3149600

Olson, J.C., Dover, P., 1976. Effects of expectation creation and disconfirmation on belief elements of cognitive structure. Advances in Consumer Research 3, 168-175.,

Overby, J.W., Lee, E.-J., 2006. The effects of utilitarian and hedonic online shopping value on consumer preference and intentions. Journal of Business Research 59, 11601166., dx.doi.org/10.1016/j.jbusres.2006.03.008

Parasuraman, A., 1997. Reflections on Gaining Competitive Advantage Through Customer Value. Journal of the Academy of Marketing Science 25, 154., dx.doi.org/10.1007/BF02894351

Parasuraman, A., 2000. Technology Readiness Index (TRI): A Multiple-Item Scale to Measure Readiness to Embrace New Technologies. Journal of Service Research 2, 307. dx.doi.org/10.1177/109467050024001

Parasuraman, A., Berry, L.L., Zeithaml, V.A., 1991. Refinement and Reassessment of the SERVQUAL Scale. Journal of Retailing 67, 420.,

Parasuraman, A., Grewal, D., 2000. Serving Customers and Consumers Effectively in the Twenty-First Century: A Conceptual Framework and Overview. Journal of the Academy of Marketing Science 28, 9., dx.doi.org/10.1177/0092070300281001

Parasuraman, A., Zeithaml, V.A., Berry, L.L., 1985. A Conceptual Model of Service Quality and Its Implications for Future Research. Journal of Marketing 49, 41-50., dx.doi.org/10.2307/1251430

Parasuraman, A., Zeithaml, V.A., Berry, L.L., 1988. SERVQUAL: A Multiple-Item Scale for Measuring Consumer Perceptions of Service Quality. Journal of Retailing 64, 12-40.,

Parasuraman, A., Zeithaml, V.A., Berry, L.L., 1994. Reassessment of Expectations as a Comparison Standard in Measuring Service Quality: Implications for Further Research. Journal of Marketing 58, 111-124., dx.doi.org/10.2307/1252255

Parasuraman, A., Zeithaml, V.A., Malhotra, A., 2005. E-S-QUAL: A Multiple-Item Scale for Assessing Electronic Service Quality. Journal of Service Research 7, 213-233., dx.doi.org/10.1177/1094670504271156

Petre, M., Minocha, S., Roberts, D., 2006. Usability beyond the website: an empiricallygrounded e-commerce evaluation instrument for the total customer experience. Behaviour \& Information Technology 25, 189-203., dx.doi.org/10.1080/01449290500331198

Qimei Chen, Wells, W.D., 1999. Attitude toward the Site. Journal of Advertising Research 39, 27-37.,

Qin, M., 2007. Consumer Behavior towards Continued Use of Online Shopping: An Extend Expectation Disconfirmation Model. Integration and Innovation Orient to ESociety, 400 - 407., dx.doi.org/10.1007/978-0-387-75466-6_45

Ranganathan, C., Ganapathy, S., 2002. Key dimensions of business-to-consumer web sites. Information \& Management 39, 457., dx.doi.org/10.1016/S0378-7206(01)00112-4 
Reichheld, F.F., Schefter, P., 2000. E-loyalty your secret weapon on the web. Harvard Business Review 78, 105-13.,

Rekettye, G., 1997. Az árak és a fogyasztói magatartás. Marketing \& Management 31, 25-31.,

Ribbink, D.,van Riel, A.C.R., Liljander, V., Streukens, S. 2004. Comfort your online customer: quality, trust and loyalty on the internet. Managing Service Quality 14, 446456., dx.doi.org/10.1108/09604520410569784

Rice, M., 1997. What makes users revisit a Web site? Marketing News 31, 12-12.,

Richins, M.L., 1983. Negative Word-of-Mouth by Dissatisfied Consumers: A Pilot Study. Journal of Marketing 47, 68-78., dx.doi.org/10.2307/3203428

Rohm, A.J., Swaminathan, V., 2004. A typology of online shoppers based on shopping motivations. Journal of Business Research 57, 748., dx.doi.org/10.1016/S01482963(02)00351-X

Rolph, E.A, Srini, S.S., 2003. E-Satisfaction and E-Loyalty_A Contingency Framework. Psychology \& Marketing, 20, 123-138., dx.doi.org/10.1002/mar.10063

Rombel, A., 2002. When an online deal's not a deal. Global Finance 16, 10.,

Rust, R.T., Lemon, K.N., 2001. E-Service and the Consumer. International Journal of Electronic Commerce 5, 85-101., dx.doi.org/10.1080/10864415.2001.11044216

Sarstedt, M., Henseler, J., and Ringle, C. M. 2011. Multi-Group Analysis in Partial Least Squares (PLS) Path Modeling: Alternative Methods and Empirical Results. Advances in International Marketing, 22: 195-218., dx.doi.org/abs/10.1108/S14747979\%282011\%290000022012

Salisbury, W.D., Chin, W.W., Gopal, A., Newsted, P.R., 2002. Research Report: Better Theory Through Measurement--Developing a Scale to Capture Consensus on Appropriation. Information Systems Research 13, 91-103., dx.doi.org/10.1287/isre.13.1.91.93

Seethamraju, R., 2004. Measurement of user-perceived web quality. http://is2.lse.ac.uk/asp/aspecis/20040153.pdf (letöltve: 2011. március 18.),

Seiders, K., Berry, L.L., Gresham, L.G., 2000. Attention, Retailers! How Convenient Is Your Convenience Strategy? Sloan Management Review 41, 79-89.,

Shankar, V., Smith, A.K., Rangaswamy, A., 2003. Customer satisfaction and loyalty in online and offline environments. International Journal of Research in Marketing 20, 153. dx.doi.org/10.1016/S0167-8116(03)00016-8

Shayesteh, L., Lu, Y., Kuo, W.-L., Baldocchi, R., Godfrey, T., Collins, C., Pinkel, D., Powell, B., Mills, G.B., Gray, J.W., 1999. PIK3CA is implicated as an oncogene in ovarian cancer. Nature Genetics 21, 99., dx.doi.org/10.1038/5042

Sheng-Hsun Hsu, Wun-Hwa Chen, Ming-Jyh Hsieh, 2006. Robustness testing of PLS, LISREL, EQS and ANN-based SEM for measuring customer satisfaction. Total Quality Management \& Business Excellence 17, 355-371., dx.doi.org/10.1080/14783360500451465

Sirkka L. Jarvenpaa and Peter Todd. 1997. Consumer Reactions to Electronic Shopping on the World Wide Web. International Journal of Electronic Commerce 1, 2, 59-88.

Skiera, B, Spann, M, Walz, U. 2005. Erlösquellen und Preismodelle für den Business-toConsumer-Bereich im Internet. WIRTSCHAFTSINFORMATIK, 285-293. 
Smith, D., Menon, S., Sivakumar, K., 2005. Online peer and editorial recommendations, trust, and choice in virtual markets. Journal of Interactive Marketing (John Wiley \& Sons) 19, 15-37., dx.doi.org/10.1002/dir.20041

Sousa, R., 2002. The relationship between quality and loyalty in multichannel e-services: an empirical investigation. http://citeseerx.ist.psu.edu/viewdoc/download?doi=10.1.1.107.2669\&rep=rep1\&type=p df (letöltve: 2012. november 14.), dx.doi.org/10.1.1.107.2669

Sousa, R., Voss, C.A., 2006. Service Quality in Multichannel Services Employing Virtual Channels. Journal of Service Research 8, 356-371., dx.doi.org/10.1177/1094670506286324

Srinivasan, S.S., Anderson, R., Ponnavolu, K., 2002. Customer loyalty in e-commerce: an exploration of its antecedents and consequences. Journal of Retailing 78, 41-50., dx.doi.org/10.1016/S0022-4359(01)00065-3

Szabó, K., Hámori, B., 2006. Információgazdaság : Digitális kapitalizmus vagy új gazdasági rendszer? Budapest: Akadémiai Kiadó.,

Szücs, K., 2011. Online fogyasztói magatartás. In: Bányai Edit, Novák Péter (szerk): Online üzlet és marketing. Budapest: Akadémiai Kiadó.,

Szymanski, D.M, Henard, D.H., 2001. Customer Satisfaction:A Meta-Analysis of the Empirical Evidence. Journal of the Academy of Marketing Science 29, 16 - 35., dx.doi.org/10.1177/009207030102900102

Szymanski, D.M., Hise, R.T., 2000. e-Satisfaction: An Initial Examination. Journal of Retailing 76, 309-322., dx.doi.org/10.1016/S0022-4359(00)00035-X

Talyigás, J., Mojzes, I., 2004. Az elektronikus kereskedelem, mint az információs társadalom kiterjesztésének katalizátora. Híradástechnika 59, 10-14.,

Teimouri, M., Yaghoubi, N.M, Kazemi, M., 2012. The Effect of Electronic Service Quality on Customers Behavioral Intentions. Intemational Joumal of Marketing Studies 4, 179 - 197., dx.doi.org/10.5539/ijms.v4n2p179

Tong, C., Kam-Sing Wong, S., Ken Pui-Hing Lui, 2012. The Influences of Service Personalization, Customer Satisfaction and Switching Costs on E-Loyalty. International Journal of Economics \& Finance 4, 105-114., dx.doi.org/10.5539/ijef.v4n3p105

Tse, D.K., Wilton, P.C., 1988. Models of Consumer Satisfaction Formation: An Extensive. Journal of Marketing Research (JMR) 25, 204-212.,

Tulluck, G., 1970. Exit, Voice and Loyalty: Responses to Decline in Firms, Organizations, and States. Journal of Finance 25, 1194-1195.,

Ursic, M.L., 1985. A Model of the Consumer Decision to Seek Legal Redress. Journal of Consumer Affairs 19, 20., dx.doi.org/10.1111/j.1745-6606.1985.tb00342.x

Vallejo, M.G., López, A.J.R., Aguilar, L.J., Lombardo, J.M.E., 2005. A study on the applicability of online service quality models in testing e-loyalty. Iadis international conference on WWW/Internet 2005, 60 - 64.,

Van Dolen, W.M., Dabholkar, P.A., de Ruyter, K., 2007. Satisfaction with Online Commercial Group Chat: The Influence of Perceived Technology Attributes, Chat Group Characteristics, and Advisor Communication Style. Journal of Retailing 83, 339-358., dx.doi.org/10.1016/j.jretai.2007.03.004 
Van Riel, A.C.R., Liljander, V., Jurriëns, P., 2001. Exploring consumer evaluations of eservices: a portal site. International Journal of Service Industry Management 12, 359 ., dx.doi.org/10.1108/09564230110405280

Venkatesh, V., Morris, M.G., Davis, G.B., Davis, F.D., 2003. User acceptance of information technology: toward a unified view. Mis Quarterly 27, 425-478., dx.doi.org/10.2307/30036540

Veres, Z., 2009. A szolgáltatásmarketing alapkönyve. Budapest: Akadémiai Kiadó.,

Weiber, R. \& Mühlhaus, D. 2010. Strukturgleichungsmodellierung, Berlin-Heidelberg, Springer.

Wei-Lun Chang, Yu-Ting Hong, 2011. A mixture model to estimate customer value for e-services. Kybernetes 40, 182-199., dx.doi.org/10.1108/03684921111117997

Westbrook, R.A., Oliver, R.L., 1991. The Dimensionality of Consumption Emotion Patterns and Consumer Satisfaction. Journal of Consumer Research 18, 84-91., dx.doi.org/10.2307/2489487

Wolfinbarger, M., Gilly, M.C, 2003. eTailQ: dimensionalizing, measuring and predicting etail quality. Journal of Retailing 79, 183-198., dx.doi.org/10.1016/S00224359(03)00034-4

Wolfinbarger, M., Gilly, M.C., 2002. comQ: Dimensionalizing, measuring and predicting quality of the e-tailing experience. CRITO - Center for research on information technology and organization, $1-42$.,

Woodruff, R.B., Cadotte, E.R., Jenkins, R.L., 1983. Modeling Consumer Satisfaction Processes Using Experience-Based Norms. Journal of Marketing Research (JMR) 20, 296-304., dx.doi.org/10.2307/3151833

Xiaoni Zhang, Prybutok, V.R., 2005. A Consumer Perspective of E-Service Quality. IEEE Transactions on Engineering Management 52, 461-477., dx.doi.org/10.1109/TEM.2005.856568

Yang, H., Tsai, F.S., 2007. General E-S-QUAL Scales Applied To Websites Satisfaction and Loyalty Model. Communications of the IIMA 7, 115-126.,

Yoo, B., Donthu, N., 2001. Developing a scale to measure the preceived quality of an internet shopping site: SITEQUAL. Quarterly Journal of Electronic Commerce, 1 - 19.,

Eszes, I., 2011. A szóbeszéd marketing alkalmazási lehetõségeinek kiterjesztése a web kettes virtuális közösségekben. A Magyar Marketing Szövetség Marketing Oktatók Klubja 17. Országos Konferenciája, Pécsi Tudományegyetem, Pécs, 2011.augusztus 2930 ,

Zeithaml, V.A., Berry, L.L., Parasuraman, A., 1996. The Behavioral Consequences of Service Quality. Journal of Marketing 60, 31-46., dx.doi.org/10.2307/1251929

Zeithaml, V.A., Parasuraman, A., Malhotra, A., 2002. Service Quality Delivery Through Web Sites: A Critical Review of Extant Knowledge. Journal of the Academy of Marketing Science 30, 362-375., dx.doi.org/10.1177/009207002236911

Zeithaml, Valarie A., Berry, Leonard L., Parasuraman, A. (1996) „The behavioral consequences of service quality", Journal of marketing, 60 (2), pp. 31-46., dx.doi.org/10.2307/1251929

Zhilin Yang, Peterson, R.T., Huang, L., 2001. Taking the Pulse of Internet Pharmacies. Marketing Health Services 21, 4-10., 


\section{Melléklet: A legfontosabb mutatók az interneteléréssel, internethasználattal, illetve online vásárlással kapcsolatban}

Forrás: Eurostat honlap

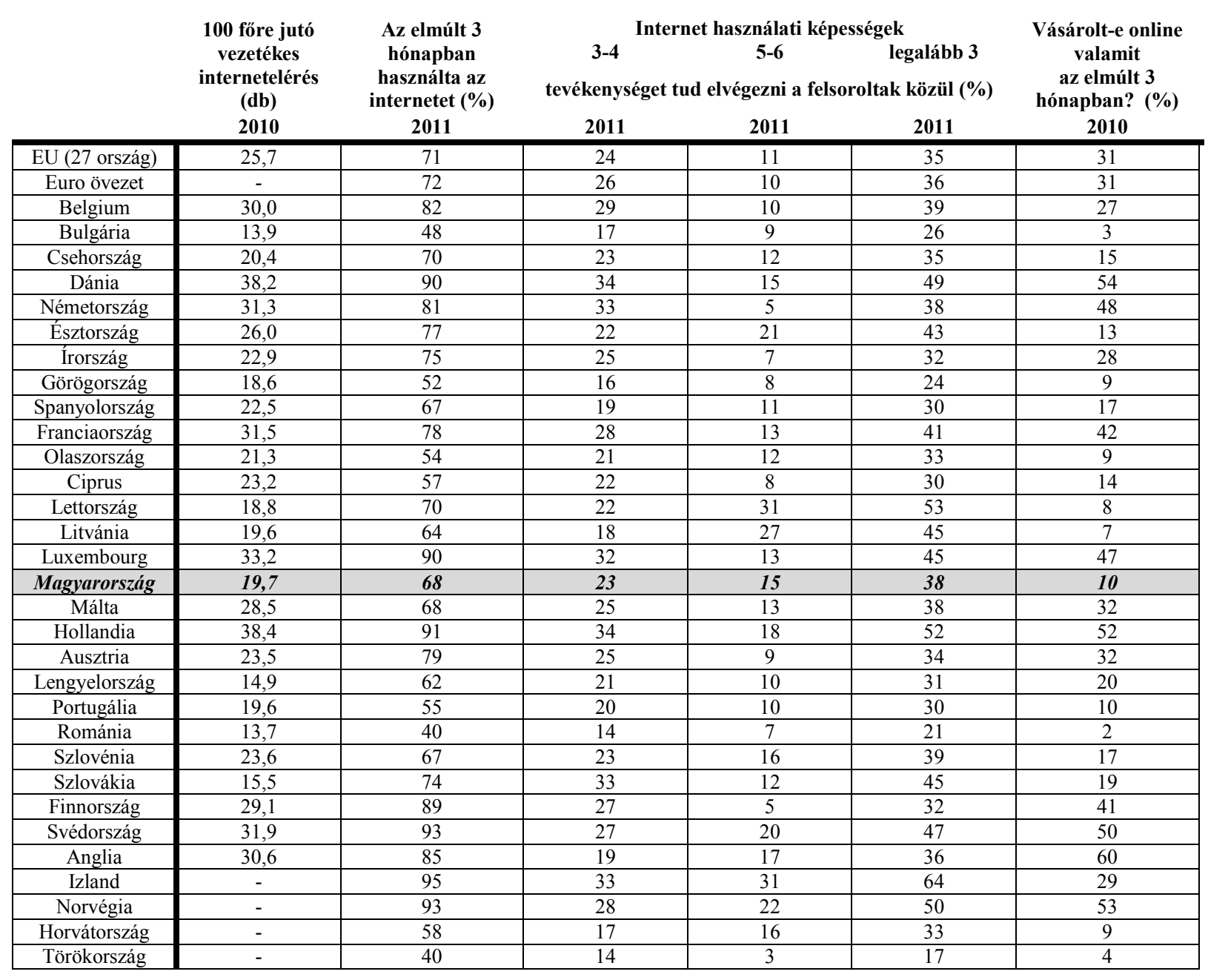




\section{Melléklet: Az EU27 országokban online vásárolt termékek és szolgáltatások}

\section{köre (\%)}

$\mathrm{N}=$ az elmúlt egy év során online vásárlók

Forrás: Eurostat honlap

\begin{tabular}{|c|c|c|c|c|c|c|c|c|c|c|c|}
\hline & 2004 & 2005 & 2006 & 2007 & 2008 & 2009 & 2010 & 2011 & 2012 & $\begin{array}{l}\text { EU27 } \\
\text { rangsor }\end{array}$ & $\begin{array}{c}\text { Mo. } \\
\text { rangsor }\end{array}$ \\
\hline Ruha, sport eszköz & 30 & 32 & 36 & 38 & 41 & 45 & 47 & 52 & 55 & 1 & 2 \\
\hline Szállás, nyaralás & 28 & 34 & 41 & 43 & 42 & 50 & 51 & 52 & 54 & 2 & 3 \\
\hline Könyv, magazin & 36 & 33 & 39 & 38 & 39 & 33 & 38 & 38 & 40 & 3 & 1 \\
\hline Háztartási eszköz & & 22 & 30 & 34 & 35 & 37 & 35 & 38 & 39 & 4 & 5 \\
\hline Belépő & 22 & 24 & 30 & 31 & 33 & 34 & 35 & 37 & 38 & 5 & 4 \\
\hline Film, zene & 30 & 31 & 34 & 33 & 29 & 32 & 32 & 29 & 29 & 6 & 7 \\
\hline Software & 15 & 18 & 25 & 24 & 21 & 29 & 29 & 25 & 25 & 7 & 10 \\
\hline Elektronikai termék & 17 & 19 & 24 & 24 & 25 & 26 & 25 & 25 & 24 & 8 & 9 \\
\hline Telekommunikációs szolg. & & & & & & 16 & 16 & 17 & 18 & 9 & 8 \\
\hline Hardware & 14 & 15 & 19 & 17 & 16 & 18 & 18 & 19 & 18 & 10 & 14 \\
\hline $\begin{array}{l}\text { Videojáték ONLINE } \\
\text { használatra, vagy } \\
\text { frissítésre }\end{array}$ & & & & & & 16 & 16 & 17 & 18 & 11 & 17 \\
\hline Étel, élelmiszer & 9 & 10 & 10 & 11 & 11 & 13 & 13 & 15 & 16 & 12 & 16 \\
\hline $\begin{array}{l}\text { Software ONLINE } \\
\text { használatra, vagy } \\
\text { frissítésre }\end{array}$ & & & 16 & 15 & 13 & 17 & 18 & 15 & & 13 & 15 \\
\hline $\begin{array}{l}\text { Film, zene ONLINE } \\
\text { használatra, vagy } \\
\text { frissítésre }\end{array}$ & & & 15 & 14 & 13 & 14 & 14 & 13 & & 14 & 13 \\
\hline Szerencsejáték & & & & & & 12 & 11 & 11 & & 15 & 12 \\
\hline Pénzügyi szolg. & 10 & 9 & 11 & 9 & 9 & 10 & 11 & 10 & 12 & 16 & 19 \\
\hline Egyéb & & 20 & 12 & 9 & 8 & 9 & 11 & 11 & 10 & 17 & 6 \\
\hline Gyógyszer & & & & & & 9 & 10 & 10 & 10 & 18 & 18 \\
\hline Könyv, magazin online & & & 14 & 10 & 11 & 8 & 9 & 9 & & 19 & 11 \\
\hline
\end{tabular}




\section{Melléklet: A RECIPE skála}

Forrás: Francis (2009): Category-specific RECIPEs for internet retailing quality. Journal of Services Marketing.

\begin{tabular}{|c|c|}
\hline $\begin{array}{l}\text { Cronbach-alpha \& } \\
\text { Faktor loadingok } \\
\text { (eredeti érték) }\end{array}$ & OFFLINE-PRODUCTS \\
\hline$\alpha=0,79$ & Website \\
\hline 0.734 & Locating information on the website was easy. \\
\hline 0.796 & The website was visually appealing. \\
\hline 0.772 & The products were described clearly. \\
\hline 0.599 & The range of products that were offered was good. \\
\hline$\alpha=0,88$ & Exchange \\
\hline 0,632 & The system for placing orders worked the first time \\
\hline 0,718 & Clear confirmation of my order was provided. \\
\hline 0,722 & Products were delivered by the expected time. \\
\hline 0,848 & I received the correct products the first time. \\
\hline 0,882 & The products arrived in good condition. \\
\hline$\alpha=0,93$ & Customer service \\
\hline 0,845 & Contacting customer service staff was easy. \\
\hline 0,748 & The company responded quickly to my emails. \\
\hline 0,905 & Communications with this firm seemed personal. \\
\hline 0,806 & The answers to my questions were helpful. \\
\hline 0,842 & The company was happy to fix any problems. \\
\hline 0,781 & It was easy to obtain help about delivery delays. \\
\hline$\alpha=0,91$ & Security \\
\hline 0,693 & The security information was explained clearly. \\
\hline 0,609 & The safety of credit card details was guaranteed. \\
\hline 0,961 & The use of my personal details was explained. \\
\hline 0,895 & My personal details were treated as confidential. \\
\hline $\begin{array}{c}\text { Cronbach-alpha \& Factor } \\
\text { loadings }\end{array}$ & OFFLINE-SERVICES \\
\hline$\alpha=0,77$ & Website \\
\hline 0,759 & The website provided useful pictures and images \\
\hline 0,796 & The website was visually appealing \\
\hline 0,772 & The service products were described clearly \\
\hline 0,599 & The range of services that were offered was good \\
\hline$\alpha=0,88$ & Reservation/purchase \\
\hline 0,707 & It was easy to make an online purchase/booking. \\
\hline 0,777 & The purchase/booking system worked the first time \\
\hline 0,78 & The purchase/booking was confirmed promptly. \\
\hline 0,815 & The confirmation message was easy to understand. \\
\hline 0,81 & The purchase/booking was processed correctly. \\
\hline$\alpha=0,91$ & Customer service \\
\hline 0,753 & Contacting customer service staff was easy \\
\hline 0,596 & The company responded quickly to my e-mails. \\
\hline 0,871 & Communications with this firm seemed personal. \\
\hline 0,894 & The answers to my questions were helpful. \\
\hline 0,722 & The company was happy to fix any problems. \\
\hline$\alpha=0,91$ & Security \\
\hline
\end{tabular}




\begin{tabular}{|c|l|}
\hline 0,8 & The security information was explained clearly. \\
\hline 0,862 & The safety of credit card details was guaranteed. \\
\hline 0,902 & The use of my personal details was explained. \\
\hline $\begin{array}{c}\text { Cronbach-alpha } \boldsymbol{\&} \\
\text { Factor loadings }\end{array}$ & ELECTRONIC-PRODUCT \\
\hline $\boldsymbol{\alpha}=\mathbf{0 , 7 0}$ & Product details \\
\hline 0,768 & The file size of digital products was specified \\
\hline 0,796 & The system requirements were explained clearly \\
\hline 0,682 & The product compatibility was indicated \\
\hline 0,583 & Products were available for pre-purchase trial \\
\hline $\boldsymbol{\alpha}=\mathbf{0 , 8 8}$ & Exchange \\
\hline 0,757 & It was easy to pay for the products online \\
\hline 0,884 & The payment system worked the first time \\
\hline 0,783 & Clear confirmation of my purchase was provided \\
\hline 0,662 & The downloading instructions were easy to follow \\
\hline 0,541 & The downloading time was reasonable \\
\hline $\mathbf{0 , 7 4 9}$ & The download process worked the first time \\
\hline $\boldsymbol{\alpha}=\mathbf{0 , 9 5}$ & Customer service \\
\hline 0,898 & Contacting customer service staff was easy. \\
\hline 0,904 & The company responded quickly to my emails. \\
\hline 0,874 & Communications with this firm seemed personal. \\
\hline 0,863 & The answers to my questions were helpful. \\
\hline 0,82 & The company was happy to fix any problems. \\
\hline $\boldsymbol{\alpha}=\mathbf{0 , 8 6}$ & Security \\
\hline 0,656 & The security information was explained clearly. \\
\hline 0,743 & The safety of credit card details was guaranteed. \\
\hline 0,903 & The use of my personal details was explained. \\
\hline 0,863 & My personal details were treated as confidential. \\
\hline & \\
\hline & \\
\hline &
\end{tabular}




\section{Melléklet: A tényleges mérési tételek és a hozzájuk tartozó kódok}

\begin{tabular}{|c|c|c|c|}
\hline \multirow{10}{*}{$\begin{array}{l}\text { Offline- } \\
\text { termékek } \\
\text { esete }\end{array}$} & \multirow{4}{*}{$\begin{array}{l}\text { Konkrét } \\
\text { web-shop } \\
\text { minőség }\end{array}$} & WEBS_OT1 & Az információ elhelyezése a honlapon megfelelő volt. \\
\hline & & WEBS_OT2 & A honlap megjelenítése/designja szép. \\
\hline & & WEBS_OT3 & A kínált termék(ek) leírása egyértelmü volt a web-shopban. \\
\hline & & WEBS_OT4 & A web-shopban kínált termékek mennyisége megfelelő. \\
\hline & \multirow{5}{*}{$\begin{array}{c}\text { Vásárlás } \\
\text { lebonyolítá } \\
\text { sa }\end{array}$} & EXCH1_OT1 & A megrendelési folyamat már elsőre jól működött. \\
\hline & & EXCH1_OT2 & $\begin{array}{l}\text { A rendelésemmel kapcsolatban egyértelmü visszaigazolást } \\
\text { nyújtottak. }\end{array}$ \\
\hline & & EXCH1_OT3 & A terméket a megfelelö/ az elvárt időben szállították. \\
\hline & & EXCH1_OT4 & A megrendelt terméke(ke)t kaptam meg már elsőre is. \\
\hline & & EXCH1_OT5 & A termék/termékek jó állapotban érkeztek meg. \\
\hline & $\begin{array}{l}\text { Ügyfélszol } \\
\text { gálat (kieg) }\end{array}$ & SC_OT_6 & $\begin{array}{l}\text { A szállítással kapcsolatos késedelmekkel kapcsolatban } \\
\text { egyszerü volt segítséget kérni. }\end{array}$ \\
\hline \multirow{9}{*}{$\begin{array}{l}\text { Offline- } \\
\text { szolgáltat } \\
\text { ások esete }\end{array}$} & \multirow{4}{*}{$\begin{array}{l}\text { Konkrét } \\
\text { web-shop } \\
\text { minőség }\end{array}$} & WEBS_OSZ1 & A holnapon hasznos képek találhatóak. \\
\hline & & WEBS_OSZ2 & A honlap megjelenítése/designja szép. \\
\hline & & WEBS_OSZ3 & $\begin{array}{l}\text { A kínált szolgáltatások leírása egyértelmü volt a web- } \\
\text { shopban. }\end{array}$ \\
\hline & & WEBS_OSZ4 & $\begin{array}{l}\text { A web-shopban kínált szolgáltatások mennyisége } \\
\text { megfelelö. }\end{array}$ \\
\hline & \multirow{5}{*}{$\begin{array}{c}\text { Vásárlás } \\
\text { lebonyolítá } \\
\text { sa }\end{array}$} & EXCH1_OSZ1 & Az online foglalás/vásárlás egyszerü volt. \\
\hline & & EXCH1_OSZ2 & A foglalási/vásárlási rendszer már elsőre jól müködött. \\
\hline & & EXCH1_OSZ3 & A foglalást/vásárlást azonnal visszaigazolták. \\
\hline & & EXCH1_OSZ4 & A visszaigazolási üzenet megértése egyszerü volt. \\
\hline & & EXCH1_OSZ5 & A foglalás/vásárlás feldolgozása jól müködött. \\
\hline \multirow{10}{*}{$\begin{array}{c}\text { E- } \\
\text { termékek } \\
\text { esete }\end{array}$} & \multirow{4}{*}{$\begin{array}{l}\text { Konkrét } \\
\text { web-shop } \\
\text { minőség }\end{array}$} & WEBS_ET1 & A letöltött fájl méretét előre meghatározták a web-shopban. \\
\hline & & WEBS_ET2 & A rendszerkövetelményeket pontosan meghatározták. \\
\hline & & WEBS_ET3 & Jelezték a termék-kompatibilitást. \\
\hline & & WEBS_ET4 & $\begin{array}{l}\text { A termékből egy ingyenes triál/próba verzió is elérhető } \\
\text { volt. }\end{array}$ \\
\hline & \multirow{6}{*}{$\begin{array}{c}\text { Vásárlás } \\
\text { lebonyolítá } \\
\text { sa }\end{array}$} & EXCH1_ET1 & Könnyű volt a termékért online fizetni. \\
\hline & & EXCH1_ET2 & A fizetési rendszer már elsőre jól működött. \\
\hline & & EXCH1_ET3 & $\begin{array}{l}\text { A rendelésemmel kapcsolatban egyértelmű visszaigazolást } \\
\text { nyújtottak. }\end{array}$ \\
\hline & & EXCH1_ET4 & A letöltési útmutatót könnyü volt követni. \\
\hline & & EXCH1_ET5 & A letöltési idő elfogadható volt. \\
\hline & & EXCH1_ET6 & A letöltés folyamata már elsőre jól müködött. \\
\hline \multirow{11}{*}{$\begin{array}{c}\text { E- } \\
\text { szolgáltat } \\
\text { ások esete }\end{array}$} & \multirow{4}{*}{$\begin{array}{l}\text { Konkrét } \\
\text { web-shop } \\
\text { minőség }\end{array}$} & WEBS_ESZ1 & $\begin{array}{l}\text { A felhasználói fiók létrehozásáról szóló útmutató } \\
\text { egyértelmü volt. }\end{array}$ \\
\hline & & WEBS_ESZ2 & A felhasználói fiók létrehozása egyszerü volt. \\
\hline & & WEBS_ESZ3 & A felhasználói fiók létrehozása már elsőre sikerült. \\
\hline & & WEBS_ESZ4 & A felhasználói fiókom/tagságom azonnal létrejött. \\
\hline & \multirow{6}{*}{$\begin{array}{c}\text { Vásárlás } \\
\text { lebonyolítá } \\
\text { sa }\end{array}$} & EXCH1_ESZ1 & A felhasználói fiókomat/tagságomat visszaigazolták. \\
\hline & & EXCH1_ESZ2 & A felhasználói fiókomba való bejelentkezés egyszerü. \\
\hline & & EXCH1_ESZ3 & Az online szolgáltatásokhoz való hozzáférés megbízható. \\
\hline & & EXCH1_ESZ4 & Az online szolgáltatások azonnal elérhetőek voltak. \\
\hline & & EXCH1_ESZ5 & A fiók/tagság használata egyszerü. \\
\hline & & EXCH1_ESZ6 & $\begin{array}{l}\text { A nyújtott online szolgáltatás olyan volt, mint amilyennek } \\
\text { leírták. }\end{array}$ \\
\hline & $\begin{array}{l}\text { Ügyfélszol } \\
\text { gálat (kieg) }\end{array}$ & CS_ESZ6 & Az ügyfélszolgálat online is elérhető. \\
\hline
\end{tabular}




\begin{tabular}{|c|c|c|c|}
\hline \multirow{17}{*}{$\begin{array}{l}\text { Minden e- } \\
\text { kereskede } \\
\quad \text { lmi } \\
\text { kategória }\end{array}$} & \multirow{4}{*}{ Biztonság } & SEC1 & $\begin{array}{l}\text { A biztonsághoz kapcsolódó információk egyértelmüen } \\
\text { voltak elmagyarázva. }\end{array}$ \\
\hline & & SEC2 & A bankkártyám/hitelkártyám biztonsága garantált volt. \\
\hline & & SEC3 & A személyes adatok felhasználását részletesen leírták. \\
\hline & & SEC4 & A személyes adataimat bizalmasan kezelték. \\
\hline & \multirow{5}{*}{$\begin{array}{l}\text { Ügyfélszol } \\
\text { gálat (kieg) }\end{array}$} & SC_1 & Az ügyfélszolgáltat elérése egyszerü volt. \\
\hline & & $\mathrm{SC} \_2$ & A vállalat gyorsan válaszolt az e-mailemre. \\
\hline & & $\mathrm{SC} \_3$ & $\begin{array}{l}\text { A vállalattal folytatott kommunikáció személyes } \\
\text { hangvételủ volt. }\end{array}$ \\
\hline & & SC_4 & $\begin{array}{l}\text { A kérdése(i)mre adott válaszok segítettek/hasznosak } \\
\text { voltak. }\end{array}$ \\
\hline & & SC_5 & $\begin{array}{l}\text { A vállalat szívesen segített a felmerülő problémák } \\
\text { kezelésében. }\end{array}$ \\
\hline & \multirow{3}{*}{$\begin{array}{c}\text { Elégedettsé } \\
\mathrm{g}\end{array}$} & SAT1 & Jó döntés volt ezen az oldalon vásárolni. \\
\hline & & SAT2 & $\begin{array}{l}\text { Ha újra vásárolnék ezen a helyen, valószínüleg ugyanúgy } \\
\text { értékelném a honlapot/céget. }\end{array}$ \\
\hline & & SAT3 & $\begin{array}{l}\text { Elégedett vagyok a döntésemmel, hogy ezen az oldalon } \\
\text { vásároltam. }\end{array}$ \\
\hline & \multirow{3}{*}{$\begin{array}{c}\text { Tr. } \\
\text { Továbbaján } \\
\text { lás }\end{array}$} & WOM1 & $\begin{array}{l}\text { Pozitív dolgokat mondanék másoknak erről a web- } \\
\text { áruházról. }\end{array}$ \\
\hline & & WOM2 & $\begin{array}{l}\text { Ajánlanám a web-áruházat azoknak, akik kíváncsiak a } \\
\text { tanácsomra. }\end{array}$ \\
\hline & & WOM3 & $\begin{array}{l}\text { Bátorítanám a barátaimat és rokonaimat, hogy használják } \\
\text { ezt a web-áruházat. }\end{array}$ \\
\hline & $\begin{array}{l}\text { E- } \\
\text { továbbajánl } \\
\text { ás }\end{array}$ & EWOM1 & $\begin{array}{l}\text { Az oldalról szívesen osztanék meg pozitív véleményt az } \\
\text { interneten. }\end{array}$ \\
\hline & $\begin{array}{l}\text { Újiravásárlá } \\
\text { si szándék }\end{array}$ & $B I 1$ & Szándékozom a közeljövőben vásárolni erről az oldalról. \\
\hline
\end{tabular}




\section{Melléklet: A felhasznált skálák hasonlósági érvényessége}

Forrás: PLS-SEM alapján saját szerkesztés

Fornell-Larcker kritérium

\begin{tabular}{|l|c|c|c|c|c|c|c|c|}
\hline & $\begin{array}{l}\text { Offline-termékek } \\
\text { Újravásárlási } \\
\text { szándék }\end{array}$ & Ügyfélszolgálat & $\begin{array}{c}\text { E- } \\
\text { WOM }\end{array}$ & $\begin{array}{c}\text { Vásárlás } \\
\text { lebonyolítása }\end{array}$ & SAT & $\begin{array}{c}\text { Újravásárlási } \\
\text { szándékztonság }\end{array}$ & $\begin{array}{c}\text { tr.- } \\
\text { WOM }\end{array}$ & $\begin{array}{c}\text { Konkrét } \\
\text { webshop } \\
\text { minóség }\end{array}$ \\
\hline $\begin{array}{l}\text { Újravásárlási } \\
\text { szándék }\end{array}$ & 1,000 & & & & & & & \\
\hline Ügyfélszolgálat & 0,691 & 0,893 & & & & & & \\
\hline E-WOM & 0,725 & 0,586 & 1,000 & & & & & \\
\hline $\begin{array}{l}\text { Vásárlás } \\
\text { lebonyolítása }\end{array}$ & 0,790 & 0,770 & 0,624 & 0,917 & & & & \\
\hline SAT & 0,879 & 0,800 & 0,708 & 0,876 & 0,984 & & & \\
\hline $\begin{array}{l}\text { Újravásárlási } \\
\text { szándékztonság }\end{array}$ & 0,594 & 0,899 & 0,530 & 0,733 & 0,728 & 0,904 & & \\
\hline tr.-WOM & 0,911 & 0,799 & 0,758 & 0,851 & 0,959 & 0,714 & 0,977 & \\
\hline $\begin{array}{l}\text { Konkrét webshop } \\
\text { minőség }\end{array}$ & 0,638 & 0,677 & 0,533 & 0,817 & 0,738 & 0,743 & 0,701 & 0,895 \\
\hline
\end{tabular}

\section{Offline-szolgáltatások}

\begin{tabular}{|l|c|c|c|c|c|c|c|c|}
\hline & $\begin{array}{c}\text { Újravásárlási } \\
\text { szándék }\end{array}$ & Ügyfélszolgálat & $\begin{array}{c}\text { E- } \\
\text { WOM }\end{array}$ & $\begin{array}{c}\text { Vásárlás } \\
\text { lebonyolítása }\end{array}$ & SAT & $\begin{array}{c}\text { Újravásárlási } \\
\text { szándékztonság }\end{array}$ & $\begin{array}{c}\text { tr.- } \\
\text { WOM }\end{array}$ & $\begin{array}{c}\text { Konkrét } \\
\text { webshop } \\
\text { minöség }\end{array}$ \\
\hline $\begin{array}{l}\text { Újravásárlási } \\
\text { szándék }\end{array}$ & 1,000 & & & & & & & \\
\hline Ügyfélszolgálat & 0,650 & 0,867 & & & & & & \\
\hline E-WOM & 0,478 & 0,535 & 1,000 & & & & & \\
\hline $\begin{array}{l}\text { Vásárlás } \\
\text { lebonyolítása }\end{array}$ & 0,654 & 0,653 & 0,546 & 0,922 & & & & \\
\hline SAT & 0,826 & 0,750 & 0,520 & 0,790 & 0,987 & & & \\
\hline $\begin{array}{l}\text { Újravásárlási } \\
\text { szándékztonság }\end{array}$ & 0,587 & 0,796 & 0,529 & 0,702 & 0,764 & 0,927 & & \\
\hline tr.-WOM & 0,832 & 0,778 & 0,648 & 0,718 & 0,901 & 0,806 & 0,973 & \\
\hline $\begin{array}{l}\text { Konkrét webshop } \\
\text { minöség }\end{array}$ & 0,567 & 0,709 & 0,540 & 0,793 & 0,708 & 0,621 & 0,652 & 0,896 \\
\hline
\end{tabular}

\section{E-termékek}

\begin{tabular}{|l|c|c|c|c|c|c|c|c|}
\hline & $\begin{array}{c}\text { Újravásárlási } \\
\text { szándék }\end{array}$ & Ügyfélszolgálat & $\begin{array}{c}\text { E- } \\
\text { WOM }\end{array}$ & $\begin{array}{c}\text { Vásárlás } \\
\text { lebonyolítása }\end{array}$ & SAT & $\begin{array}{c}\text { Újravásárlási } \\
\text { szándékztonság }\end{array}$ & $\begin{array}{c}\text { tr.- } \\
\text { WOM }\end{array}$ & $\begin{array}{c}\text { Konkrét } \\
\text { webshop } \\
\text { minóség }\end{array}$ \\
\hline $\begin{array}{l}\text { Újravásárlási } \\
\text { szándék }\end{array}$ & 1,000 & & & & & & & \\
\hline Ügyfélszolgálat & 0,590 & 0,940 & & & & & & \\
\hline E-WOM & 0,605 & 0,501 & 1,000 & & & & & \\
\hline $\begin{array}{l}\text { Vásárlás } \\
\text { lebonyolítása }\end{array}$ & 0,568 & 0,721 & 0,387 & 0,932 & & & & \\
\hline SAT & 0,799 & 0,646 & 0,678 & 0,613 & 0,960 & & & \\
\hline $\begin{array}{l}\text { Újravásárlási } \\
\text { szándékztonság }\end{array}$ & 0,724 & 0,820 & 0,574 & 0,793 & 0,733 & 0,944 & & \\
\hline tr.-WOM & 0,866 & 0,694 & 0,723 & 0,614 & 0,919 & 0,751 & 0,980 & \\
\hline $\begin{array}{l}\text { Konkrét webshop } \\
\text { minóség }\end{array}$ & 0,422 & 0,579 & 0,331 & 0,556 & 0,427 & 0,544 & 0,478 & 0,826 \\
\hline
\end{tabular}




\begin{tabular}{|l|c|c|c|c|c|c|c|c|} 
& $\begin{array}{c}\text { Újravásárlási } \\
\text { szándék }\end{array}$ & Ügyfélszolgálat & $\begin{array}{c}\text { E- } \\
\text { WOM }\end{array}$ & $\begin{array}{c}\text { Vásárlás } \\
\text { lebonyolítása }\end{array}$ & SAT & $\begin{array}{c}\text { Újravásárlási } \\
\text { szándékztonság }\end{array}$ & $\begin{array}{c}\text { tr.- } \\
\text { WOM }\end{array}$ & $\begin{array}{c}\text { Konkrét } \\
\text { webshop } \\
\text { minóség }\end{array}$ \\
\hline $\begin{array}{l}\text { Újravásárlási } \\
\text { szándék }\end{array}$ & 1,000 & & & & & & & \\
\hline Ügyfélszolgálat & 0,674 & 0,861 & & & & & & \\
\hline E-WOM & 0,521 & 0,561 & 1,000 & & & & & \\
\hline $\begin{array}{l}\text { Vásárlás } \\
\text { lebonyolítása }\end{array}$ & 0,462 & 0,723 & 0,406 & 0,888 & & & & \\
\hline SAT & 0,658 & 0,810 & 0,492 & 0,743 & 0,966 & & & \\
\hline $\begin{array}{l}\text { Újravásárlási } \\
\text { szándékztonság }\end{array}$ & 0,506 & 0,756 & 0,340 & 0,846 & 0,796 & 0,896 & & \\
\hline tr.-WOM & 0,765 & 0,834 & 0,688 & 0,693 & 0,846 & 0,683 & 0,961 & \\
\hline $\begin{array}{l}\text { Konkrét webshop } \\
\text { minőség }\end{array}$ & 0,505 & 0,705 & 0,384 & 0,947 & 0,757 & 0,840 & 0,695 & 0,890 \\
\hline
\end{tabular}




\section{Melléklet: A látensekhez tartozó indikátorok súlyai (loadingok) - teljes} tapasztalattal rendelkezők

\begin{tabular}{|c|c|}
\hline & Loadingok \\
\hline \multicolumn{2}{|c|}{ Off-termékek esete } \\
\hline k7ai_10_CS6 <- Consumer service & 0,168 \\
\hline k7ai_1_WEBS1 <- Website design & 0,331 \\
\hline k7ai_2_WEBS2 <- Website design & 0,221 \\
\hline k7ai_3_WEBS3 <- Website design & 0,314 \\
\hline k7ai_4_WEBS4 <- Website design & 0,309 \\
\hline k7ai_5_EXCH1 <- Exchange & 0,256 \\
\hline k7ai_6_EXCH2 <- Exchange & 0,231 \\
\hline k7ai_7_EXCH3 <- Exchange & 0,226 \\
\hline k7ai_8_EXCH4 <- Exchange & 0,247 \\
\hline k7ai_9_EXCH5 <- Exchange & 0,216 \\
\hline k8_1_SEC1 <- Security & 0,365 \\
\hline k8_2_SEC2 <- Security & 0,248 \\
\hline k8_3_SEC3 <- Security & 0,297 \\
\hline k8_4_SEC4 <- Security & 0,282 \\
\hline k8_5_SC1 <- Consumer service & 0,244 \\
\hline k8_6_SC2 <-Consumer service & 0,219 \\
\hline k8_7_SC3 <- Consumer service & 0,175 \\
\hline k8_8_SC4 <- Consumer service & 0,212 \\
\hline k8_9_SC5 <-Consumer service & 0,205 \\
\hline k9_1_SAT $<-$ SAT & 0,352 \\
\hline k9_2_SAT $<-\mathrm{SAT}$ & 0,327 \\
\hline k9_3_SAT $<-$ SAT & 0,358 \\
\hline k9_4_WOM <- WOM intention & 0,357 \\
\hline k9_5_BI $<-$ BI & 1,000 \\
\hline k9_6_WOM $<-$ WOM intention & 0,340 \\
\hline k9_7_WOM <- WOM intention & 0,333 \\
\hline k9_8_EWOM <- E-WOM & 1,000 \\
\hline \multicolumn{2}{|c|}{ Off-szolgáltatások esete } \\
\hline k7aii_1_WEBS1 <- Website design & 0,227 \\
\hline k7aii_2_WEBS2 <- Website design & 0,286 \\
\hline k7aii_3_WEBS3 <- Website design & 0,354 \\
\hline k7aii_4_WEBS4 <- Website design & 0,325 \\
\hline k7aii_5_RES1 <- Reservation & 0,200 \\
\hline k7aii_6_RES2 <- Reservation & 0,210 \\
\hline k7aii_7_RES3 <- Reservation & 0,239 \\
\hline k7aii_8_RES4 <- Reservation & 0,220 \\
\hline k7aii_9_RES5 <- Reservation & 0,235 \\
\hline k8_1_SEC1 <- Security & 0,269 \\
\hline k8_2_SEC2 <- Security & 0,251 \\
\hline k8_3_SEC3 <- Security & 0,289 \\
\hline k8_4_SEC4 <- Security & 0,309 \\
\hline k8_5_SC1 <- Consumer service & 0,271 \\
\hline
\end{tabular}




\begin{tabular}{|c|c|}
\hline k8_6_SC2 <-Consumer service & 0,254 \\
\hline k8_7_SC3 <-Consumer service & 0,231 \\
\hline k8_8_SC4 <-Consumer service & 0,196 \\
\hline k8_9_SC5 <-Consumer service & 0,231 \\
\hline k9_1_SAT $<-$ SAT & 0,348 \\
\hline k9_2_SAT $<-$ SAT & 0,340 \\
\hline k9_3_SAT $<-$ SAT & 0,351 \\
\hline k9_4_WOM $<-$ WOM intention & 0,338 \\
\hline $\mathrm{k} 9 \_5 \_\mathrm{BI}<-\mathrm{BI}$ & 1,000 \\
\hline k9_6_WOM $<-$ WOM intention & 0,349 \\
\hline k9_7_WOM $<-$ WOM intention & 0,351 \\
\hline k9_8_EWOM <- E-WOM & 1,000 \\
\hline \multicolumn{2}{|l|}{ E-termékek esete } \\
\hline k7bi_10_EXCH6 <- Exchange & 0,177 \\
\hline k7bi_1_PROD1 <- Product description & 0,272 \\
\hline k7bi_2_PROD2 <- Product description & 0,340 \\
\hline k7bi_3_PROD3 <- Product description & 0,355 \\
\hline k7bi_4_PROD4 <- Product description & 0,234 \\
\hline k7bi_5_EXCH1 <- Exchange & 0,224 \\
\hline k7bi_6_EXCH2 <- Exchange & 0,235 \\
\hline k7bi_7_EXCH3 <- Exchange & 0,219 \\
\hline k7bi_8_EXCH4 <- Exchange & 0,172 \\
\hline k7bi_9_EXCH5 <- Exchange & 0,158 \\
\hline k8_1_SEC1 <- Security & 0,238 \\
\hline k8_2_SEC2 $<-$ Security & 0,357 \\
\hline k8_3_SEC3 <- Security & 0,239 \\
\hline k8_4_SEC4 $<-$ Security & 0,309 \\
\hline k8_5_SC1 <-Consumer service & 0,240 \\
\hline k8_6_SC2 <-Consumer service & 0,244 \\
\hline k8_7_SC3 <-Consumer service & 0,191 \\
\hline k8_8_SC4 <-Consumer service & 0,203 \\
\hline k8_9_SC5 <-Consumer service & 0,237 \\
\hline k9_1_SAT $<-$ SAT & 0,384 \\
\hline k9_2_SAT $<-$ SAT & 0,319 \\
\hline k9_3_SAT $<-$ SAT & 0,368 \\
\hline k9_4_WOM $<-$ WOM intention & 0,384 \\
\hline k9 5_BI $<-$ BI & 1,000 \\
\hline k9_6_WOM <- WOM intention & 0,337 \\
\hline k9_7_WOM $<-$ WOM intention & 0,342 \\
\hline k9_8_EWOM <- E-WOM & 1,000 \\
\hline \multicolumn{2}{|l|}{ E-szolgáltatások esete } \\
\hline k7bii_10_OSERV6 <- Online Services & 0,256 \\
\hline k7bii_11_CS6 <-Consumer service & 0,150 \\
\hline k7bii_1_SETUP1 <- Setup & 0,307 \\
\hline k7bii_2_SETUP2 <- Setup & 0,315 \\
\hline k7bii_3_SETUP3 <- Setup & 0,276 \\
\hline k7bii_4_SETUP4 <- Setup & 0,243 \\
\hline k7bii_5_OSERV1 <- Online Services & 0,167 \\
\hline
\end{tabular}




\begin{tabular}{|c|c|}
\hline k7bii_6_OSERV2 <- Online Services & 0,207 \\
\hline k7bii_7_OSERV3 <- Online Services & 0,201 \\
\hline k7bii_8_OSERV4 <- Online Services & 0,165 \\
\hline k7bii_9_OSERV5 <- Online Services & 0,215 \\
\hline k8_1_SEC1 <- Security & 0,298 \\
\hline k8_2_SEC2 <- Security & 0,273 \\
\hline k8_3_SEC3 <- Security & 0,281 \\
\hline k8_4_SEC4 <- Security & 0,320 \\
\hline $\mathrm{k} 8$ 5_SC $1<-$ Consumer service & 0,210 \\
\hline k8_6_SC2 <-Consumer service & 0,221 \\
\hline k8_7_SC3<-Consumer service & 0,171 \\
\hline k8_8_SC4 <- Consumer service & 0,247 \\
\hline k8_9_SC5 <-Consumer service & 0,243 \\
\hline k9_1_SAT $<-$ SAT & 0,349 \\
\hline k9_2_SAT $<-$ SAT & 0,334 \\
\hline k9_3_SAT $<-$ SAT & 0,367 \\
\hline k9_4_WOM <- WOM intention & 0,388 \\
\hline k9_5_BI $<-\mathrm{BI}$ & 1,000 \\
\hline k9_6_WOM $<-$ WOM intention & 0,334 \\
\hline k9_7_WOM <- WOM intention & 0,339 \\
\hline k9_8_EWOM <- E-WOM & 1,000 \\
\hline
\end{tabular}




\section{Melléklet: PLS útelezmés eredményei, amennyiben a hiányzó értékeket átlaggal helyettesítjük}

\section{Útegyütthatók}

Forrás: PLS-SEM alapján saját szerkesztés

\begin{tabular}{|c|c|c|c|c|c|}
\hline & & $\begin{array}{c}\text { Hiányos ügyfélszolg. } \\
\text { és biztonság }\end{array}$ & $\begin{array}{c}\text { Hiányos } \\
\text { biztonság }\end{array}$ & $\begin{array}{c}\text { Hiányos } \\
\text { ügyfélszolg. }\end{array}$ & $\begin{array}{l}\text { Hiánytalan } \\
\text { tapasztalat }\end{array}$ \\
\hline \multirow[b]{2}{*}{$\begin{array}{c}\text { Konkrét } \\
\text { webshop- } \\
\text { minőség -> } \\
\text { SAT }\end{array}$} & Útegyüttható & $-0,112$ & $-0,058$ & $-0,021$ & 0,018 \\
\hline & $\begin{array}{c}\text { p érték Hiánytalan } \\
\text { és adott dimenzió } \\
\text { összehasonlítása } \\
\text { esetén }\end{array}$ & 0,940 & 0,750 & 0,667 & \\
\hline \multirow[b]{2}{*}{$\begin{array}{l}\text { Vásárlás } \\
\text { lebony. -> } \\
\text { SAT }\end{array}$} & Útegyüttható & 0,300 & 0,488 & 0,117 & 0,341 \\
\hline & $\begin{array}{l}\text { p érték hiánytalan } \\
\text { és adott dimenzió } \\
\text { összehasonlítása } \\
\text { esetén }\end{array}$ & 0,636 & 0,198 & 0,933 & \\
\hline \multirow[b]{2}{*}{$\begin{array}{l}\text { Ügyfélszolg. - } \\
\text { > SAT }\end{array}$} & Útegyüttható & 0,203 & 0,375 & 0,094 & 0,277 \\
\hline & $\begin{array}{c}\text { p érték hiánytalan } \\
\text { és adott dimenzió } \\
\text { összehasonlítása } \\
\text { esetén }\end{array}$ & 0,721 & 0,240 & 0,922 & \\
\hline \multirow[b]{2}{*}{$\begin{array}{l}\text { Biztonság -> } \\
\text { SAT }\end{array}$} & Útegyüttható & 0,254 & $-0,027$ & 0,524 & 0,244 \\
\hline & $\begin{array}{l}\text { p érték hiánytalan } \\
\text { és adott dimenzió } \\
\text { összehasonlítása } \\
\text { esetén }\end{array}$ & 0,468 & 0,967 & 0,023 & \\
\hline \multirow[b]{2}{*}{$\begin{array}{l}\text { SAT } \rightarrow \text { tr. } \\
\text { WOM }\end{array}$} & Útegyüttható & 0,852 & 0,865 & 0,775 & 0,906 \\
\hline & $\begin{array}{l}\text { p érték hiánytalan } \\
\text { és adott dimenzió } \\
\text { összehasonlítása } \\
\text { esetén }\end{array}$ & 0,944 & 0,850 & 0,991 & \\
\hline \multirow[b]{2}{*}{$\begin{array}{l}\text { SAT }->\text { E- } \\
\text { WOM }\end{array}$} & Útegyüttható & 0,300 & 0,510 & 0,333 & 0,605 \\
\hline & $\begin{array}{c}\text { p érték hiánytalan } \\
\text { és adott dimenzió } \\
\text { összehasonlítása } \\
\text { esetén }\end{array}$ & 1,000 & 0,875 & 1,000 & \\
\hline \multirow[b]{2}{*}{ SAT $->$ BI } & Útegyüttható & 0,607 & 0,573 & 0,495 & 0,791 \\
\hline & $\begin{array}{l}\text { p érték hiánytalan } \\
\text { és adott dimenzió } \\
\text { összehasonlítása } \\
\text { esetén }\end{array}$ & 0,996 & 0,998 & 1,000 & \\
\hline
\end{tabular}

\section{$\mathbf{R}^{2}$ mutató értéke}

Forrás: PLS-SEM alapján saját szerkesztés

\begin{tabular}{|c|c|c|c|c|c|}
\hline & & $\begin{array}{c}\text { Hiányos } \\
\text { ügyfélszolg. } \\
\text { és biztonság }\end{array}$ & $\begin{array}{l}\text { Hiányos } \\
\text { biztonság }\end{array}$ & $\begin{array}{c}\text { Hiányos } \\
\text { ügyfélszolg. }\end{array}$ & $\begin{array}{l}\text { Hiánytalan } \\
\text { tapasztalat }\end{array}$ \\
\hline \multirow{3}{*}{ SAT } & $\mathrm{R} 2$ & 0,250 & 0,470 & 0,391 & 0,645 \\
\hline & $\begin{array}{c}\text { p érték hiánytalan és } \\
\text { adott dimenzió } \\
\text { összehasonlítása } \\
\text { esetén }\end{array}$ & 0,000 & 0,112 & 0,005 & \\
\hline & $\mathrm{R} 2$ & 0,725 & 0,749 & 0,601 & 0,821 \\
\hline
\end{tabular}




\begin{tabular}{|c|c|c|c|c|c|}
\hline $\begin{array}{l}\text { tr. WOM } \\
\text { hajlandóság }\end{array}$ & $\begin{array}{c}\text { p érték hiánytalan és } \\
\text { adott dimenzió } \\
\text { összehasonlítása } \\
\text { esetén }\end{array}$ & 0,109 & 0,292 & 0,009 & \\
\hline \multirow[b]{2}{*}{ E-WOM } & $\mathrm{R} 2$ & 0,090 & 0,260 & 0,111 & 0,366 \\
\hline & $\begin{array}{c}\text { p érték hiánytalan és } \\
\text { adott dimenzió } \\
\text { összehasonlítása } \\
\text { esetén }\end{array}$ & 0,000 & 0,268 & 0,001 & \\
\hline \multirow[b]{2}{*}{ BI } & $\mathrm{R} 2$ & 0,369 & 0,328 & 0,245 & 0,625 \\
\hline & $\begin{array}{c}\text { p érték hiánytalan és } \\
\text { adott dimenzió } \\
\text { összehasonlítása } \\
\text { esetén }\end{array}$ & 0,003 & 0,002 & 0,000 & \\
\hline
\end{tabular}




\section{Melléklet: Indirekt utak (teljes tapasztalattal rendelkezők)}

\begin{tabular}{|c|c|c|c|c|c|c|c|c|c|c|c|c|}
\hline \multirow[b]{3}{*}{$\begin{array}{l}\text { Konkrét } \\
\text { website } \\
\text { minőség -> } \\
\text { BI }\end{array}$} & \multicolumn{3}{|c|}{ Offline-termék } & \multicolumn{3}{|c|}{ Offline-szolgáltatás } & \multicolumn{3}{|c|}{ E-termék } & \multicolumn{3}{|c|}{ E-szolgáltatás } \\
\hline & \multirow{2}{*}{$\begin{array}{l}\text { Coeff } \\
0,056\end{array}$} & \multicolumn{2}{|c|}{ p-érték } & \multirow{2}{*}{$\begin{array}{l}\text { Coef } \\
0,042\end{array}$} & \multicolumn{2}{|c|}{ p-érték } & \multirow{2}{*}{\begin{tabular}{|l} 
Coef \\
0,005
\end{tabular}} & \multicolumn{2}{|c|}{ p-érték } & \multirow{2}{*}{$\begin{array}{l}\text { Coef } \\
0,208\end{array}$} & \multicolumn{2}{|c|}{ p-érték } \\
\hline & & $\begin{array}{l}\text { nem } \\
\text { szig. }\end{array}$ & 0,460 & & $\begin{array}{l}\text { nem } \\
\text { szig. }\end{array}$ & 0,785 & & $\begin{array}{l}\text { nem } \\
\text { szig. }\end{array}$ & 0,932 & & $\begin{array}{l}\text { nem } \\
\text { szig. }\end{array}$ & 0,132 \\
\hline $\begin{array}{l}\text { Konkrét } \\
\text { website } \\
\text { minőség -> } \\
\text { E-WOM }\end{array}$ & 0,045 & $\begin{array}{l}\text { nem } \\
\text { szig. }\end{array}$ & 0,461 & 0,027 & $\begin{array}{l}\text { nem } \\
\text { szig. }\end{array}$ & 0,786 & 0,004 & $\begin{array}{l}\text { nem } \\
\text { szig. }\end{array}$ & 0,932 & 0,156 & $\begin{array}{l}\text { nem } \\
\text { szig. }\end{array}$ & 0,146 \\
\hline $\begin{array}{l}\text { Konkrét } \\
\text { website } \\
\text { minőség -> } \\
\text { WOM } \\
\text { intention }\end{array}$ & 0,061 & $\begin{array}{l}\text { nem } \\
\text { szig. }\end{array}$ & 0,460 & 0,046 & $\begin{array}{l}\text { nem } \\
\text { szig. }\end{array}$ & 0,783 & 0,006 & $\begin{array}{l}\text { nem } \\
\text { szig. }\end{array}$ & 0,932 & 0,268 & $\begin{array}{l}\text { nem } \\
\text { szig. }\end{array}$ & 0,111 \\
\hline $\begin{array}{l}\text { Vásárlás } \\
\text { lebonyolítás } \\
\text { ának min -> } \\
\text { BI }\end{array}$ & 0,533 & szig & 0,000 & 0,345 & szig & 0,023 & 0,048 & $\begin{array}{l}\text { nem } \\
\text { szig. }\end{array}$ & 0,643 & $0, \overline{104}$ & $\begin{array}{l}\text { nem } \\
\text { szig. }\end{array}$ & 0,532 \\
\hline $\begin{array}{l}\text { Vásárlás } \\
\text { lebonyolítás } \\
\text { ának min -> } \\
\text { E-WOM }\end{array}$ & 0,429 & szig & 0,000 & 0,217 & szig & 0,044 & 0,041 & $\begin{array}{l}\text { nem } \\
\text { szig. }\end{array}$ & 0,639 & $0, \overline{-}$ & $\begin{array}{l}\text { nem } \\
\text { szig. }\end{array}$ & 0,536 \\
\hline $\begin{array}{l}\text { Vásárlás } \\
\text { lebonyolítás } \\
\text { ának min -> } \\
\text { WOM } \\
\text { intention }\end{array}$ & 0,581 & szig & 0,000 & 0,376 & szig & 0,019 & 0,056 & $\begin{array}{l}\text { nem } \\
\text { szig. }\end{array}$ & 0,642 & $0, \overline{133}$ & $\begin{array}{l}\text { nem } \\
\text { szig. }\end{array}$ & 0,523 \\
\hline $\begin{array}{l}\text { Ügyfélszolgá } \\
\text { lat -> BI }\end{array}$ & 0,357 & szig & 0,001 & 0,207 & $\begin{array}{l}\text { nem } \\
\text { szig. }\end{array}$ & 0,272 & 0,097 & $\begin{array}{l}\text { nem } \\
\text { szig. }\end{array}$ & 0,371 & 0,306 & szig & 0,001 \\
\hline $\begin{array}{l}\text { Ügyfélszolgá } \\
\text { lat -> E- } \\
\text { WOM }\end{array}$ & 0,288 & szig & 0,003 & 0,130 & $\begin{array}{l}\text { nem } \\
\text { szig. }\end{array}$ & 0,278 & 0,082 & $\begin{array}{l}\text { nem } \\
\text { szig. }\end{array}$ & 0,379 & 0,228 & szig & 0,002 \\
\hline $\begin{array}{l}\text { Ügyfélszolgá } \\
\text { lat -> WOM } \\
\text { intention }\end{array}$ & 0,390 & szig & 0,001 & 0,226 & $\begin{array}{l}\text { nem } \\
\text { szig. }\end{array}$ & 0,263 & 0,112 & $\begin{array}{l}\text { nem } \\
\text { szig. }\end{array}$ & 0,376 & 0,393 & szig & 0,000 \\
\hline $\begin{array}{l}\text { Biztonság -> } \\
\text { BI }\end{array}$ & $-0,114$ & $\begin{array}{l}\text { nem } \\
\text { szig. }\end{array}$ & 0,403 & 0,198 & $\begin{array}{l}\text { nem } \\
\text { szig. }\end{array}$ & 0,264 & 0,465 & szig & 0,001 & 0,206 & szig & 0,020 \\
\hline $\begin{array}{l}\text { Biztonság -> } \\
\text { E-WOM }\end{array}$ & $-0,092$ & $\begin{array}{l}\text { nem } \\
\text { szig. }\end{array}$ & 0,407 & 0,125 & $\begin{array}{l}\text { nem } \\
\text { szig. }\end{array}$ & 0,280 & 0,394 & szig & 0,002 & 0,154 & szig & 0,020 \\
\hline $\begin{array}{l}\text { Biztonság -> } \\
\text { WOM } \\
\text { intention }\end{array}$ & $-0,124$ & $\begin{array}{l}\text { nem } \\
\text { szig. }\end{array}$ & 0,401 & 0,217 & $\begin{array}{l}\text { nem } \\
\text { szig. }\end{array}$ & 0,274 & 0,534 & szig & 0,000 & 0,264 & szig & 0,013 \\
\hline
\end{tabular}


9. Melléklet: A Csak egy kattintás.hu web-shop - Életképek
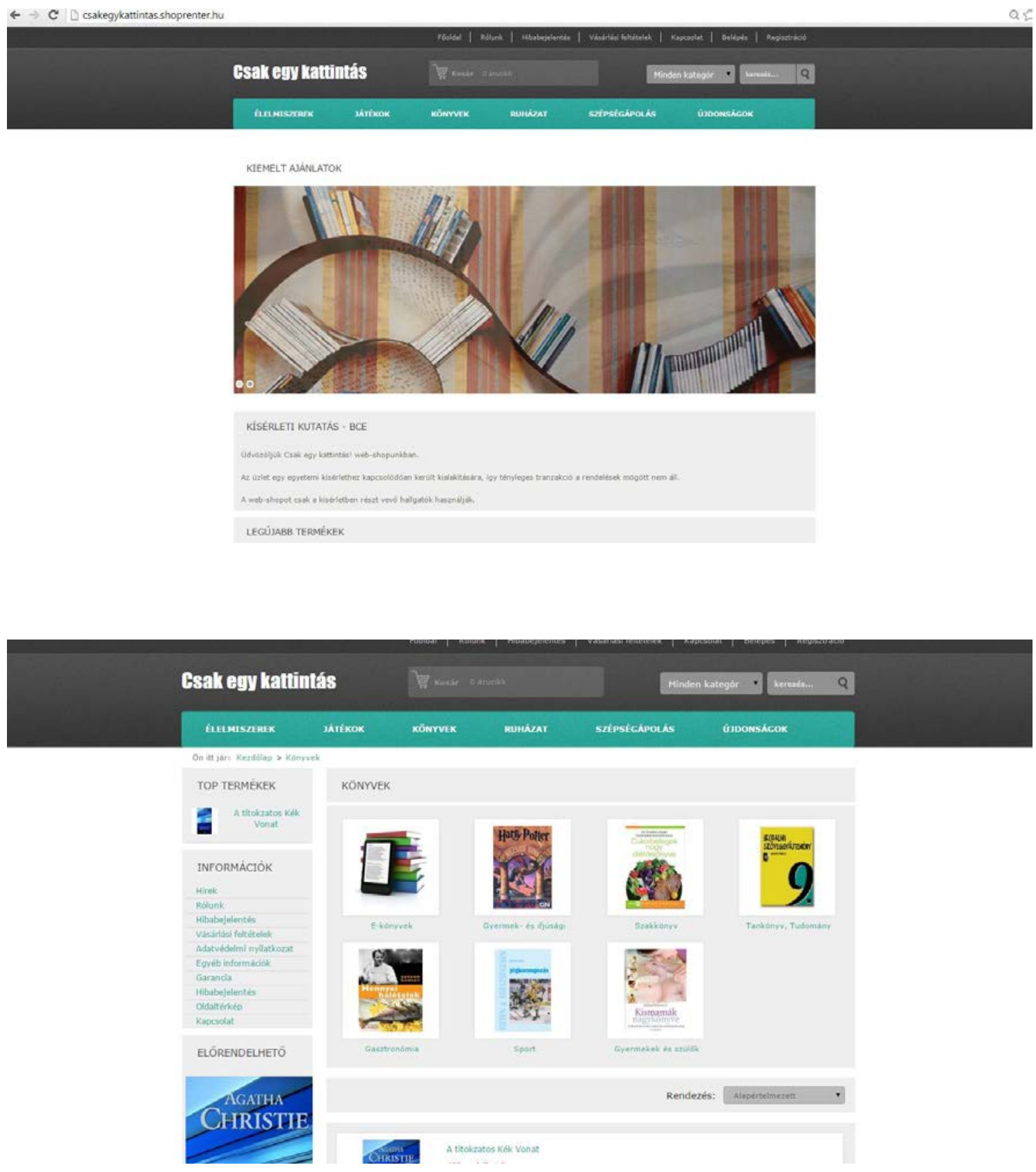

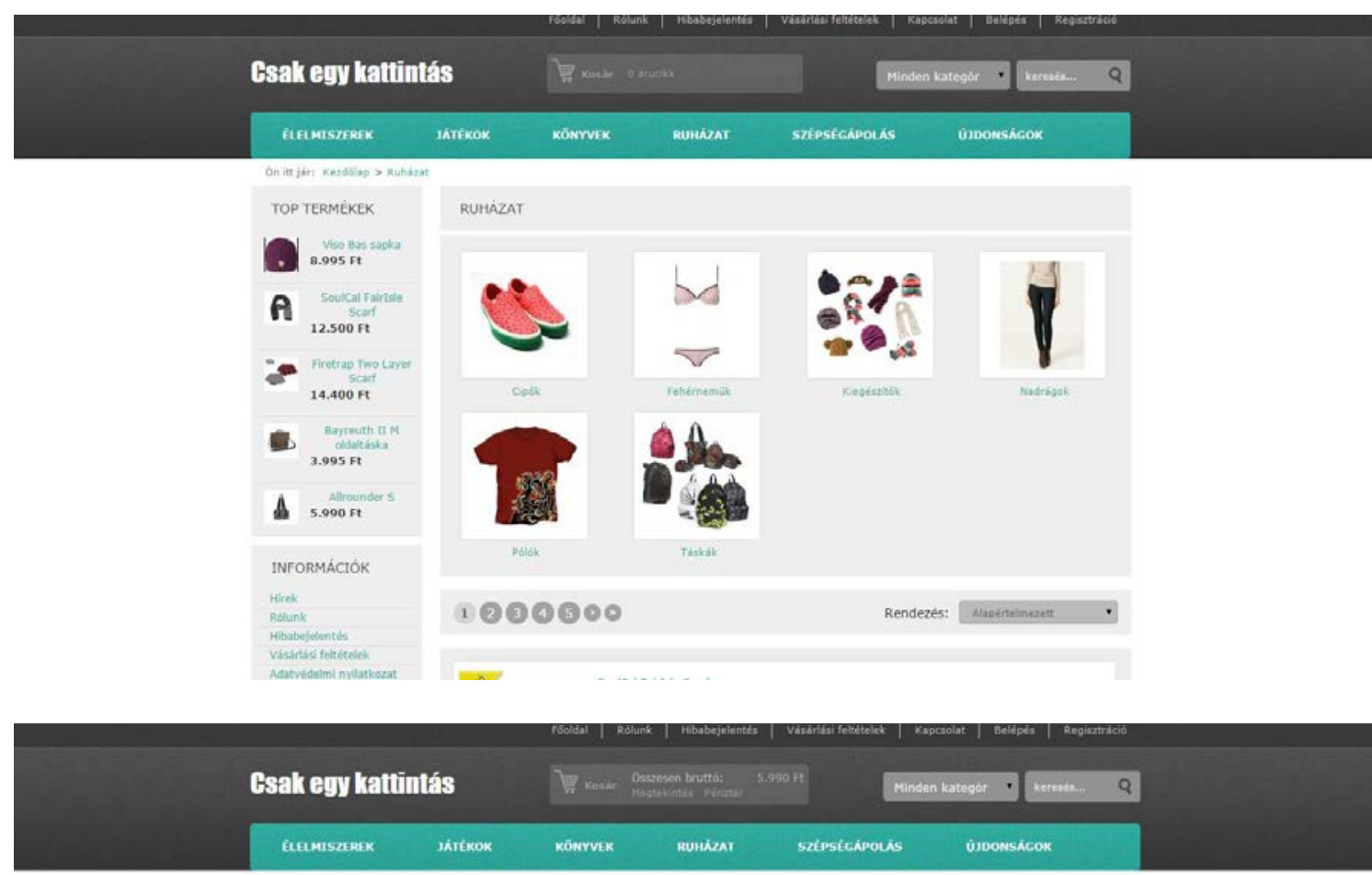

Pénztár

Vissza a kosabrhoz

1 BEJELENTEZZES

Uj vałsarló vagyok

vesariasi lehetostegek:

Repistratió

o vassarlas reoistróción nélkäit

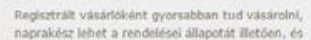

Torelemmel kisethiet korabdi rendeleseit.

Tovabb

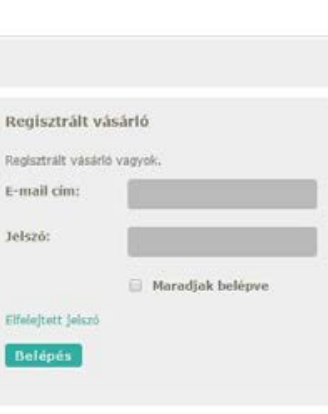

SZEMĖIYES ADATOK

SZÁMLÁZÁSI CIM

SZÄUITÁSI CIM

SZALUTÁASI MÓO

FIZETEST MOD

2 ADATOK MEGADASA

3 SZALITASIMOD

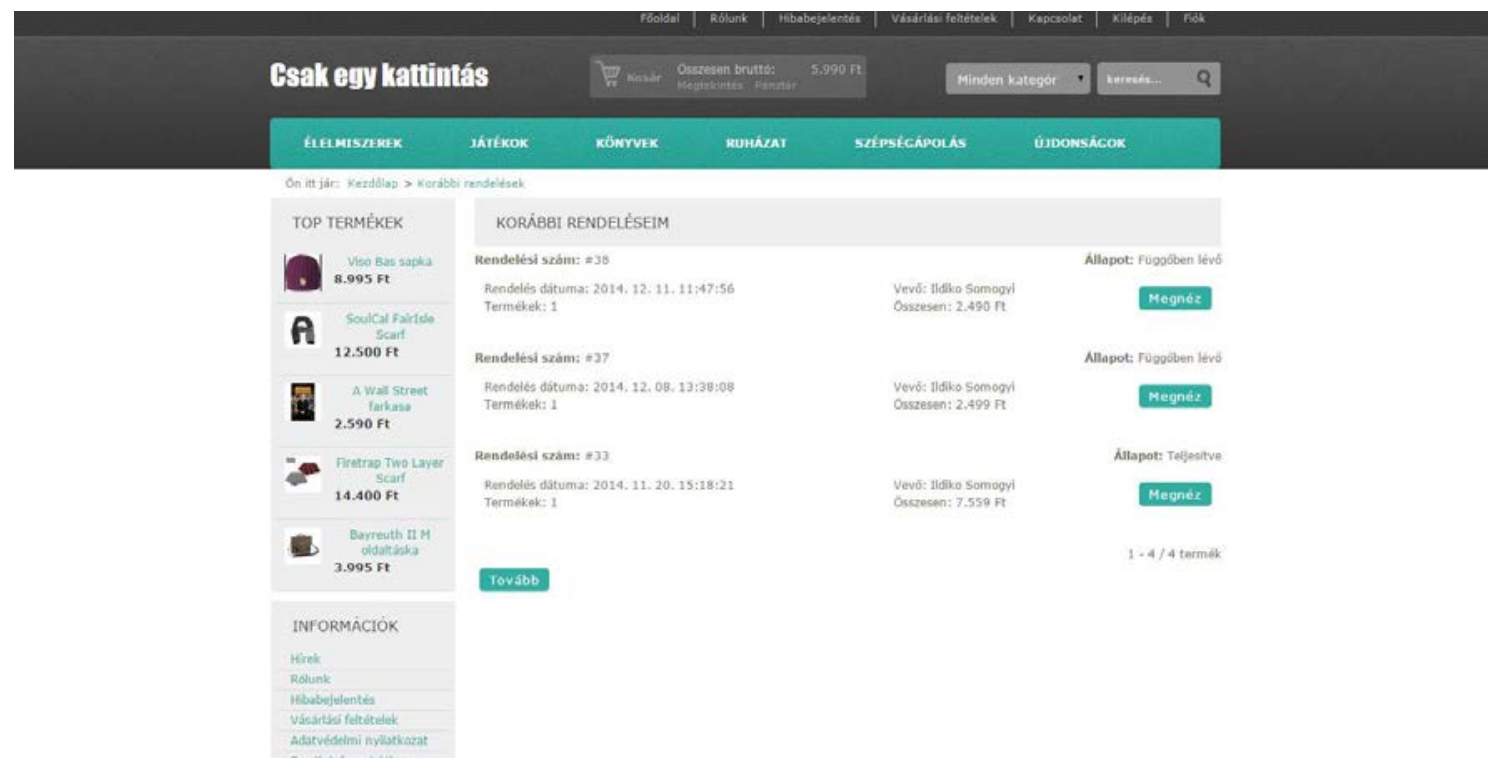




\section{Melléklet: A kísérlet leírása}

\section{OFFLINE-TERMÉK VÁSÁRLÁSÁNAK SZITUÁCIÓJA:}

A rokonaid karácsony alkalmából egy ruházati kiegészítővel szeretnének meglepni. Mivel nem tudják pontosan, milyen az izlésed, ezért megkértek, hogy az általuk meghatározott összeghatárig vásárolj magadnak valamilyen ruházati kiegészítöt (sapka/sál/kesztyü/táska).

A Csak egy kattintás webshopot felhasználva vásárold meg magadnak a kiválasztott ruházati kiegészitöt / kiegészítöket, melyek összegzett maximum értéke ne legyen több, mint 8.300 Ft a kiszállítási díj nélkül.

A vásárlásod során válaszd a házhozszállitást és az utánvételes fizetést.

A vásárlásod megvalósulásáról egy e-mailt kapsz a megadott e-mail címre, melyben egy linken találod a további instrukciókat.

A webshop: http://csakegykattintas.shoprenter.hu/

\section{E-TERMÉK VÁSÁRLÁSÁNAK SZITUÁCIÓJA:}

A legjobb barátod / barátnö születésnapja alkalmából egy Kindle 6 e-könyv olvasót kapott a családjától, mely a következö paraméterekkel bír:

- Kijelzö: 6 hüvelyk (15,2 cm) képátlójú, e-Ink Pearl kijelzö, 16 szürkeárnyalattal. A képernyö érintöpaneles.

- Méretek: 166 * $115 * 9$ mm nagyságú és 170 gramm súlyú készülék.

- WiFi: beépített WiFi, amely a szabványos 802.11 b, $802.11 \mathrm{~g}$ vagy 802.11 n hálózatokat ismeri fel és tud kapcsolódni ezekhez

- Akkumulátor: WiFi használat nélkül és napi fél óra olvasási idöt feltételezve a készülék teljes feltöltését követöen nagyjából egy hónapig müködöképes.

- támogatott formátumok:

- Szövegformátumok: AZW, TXT, PDF, MOBI, PRC, HTML, DOC, DOCX.

- Képformátumok: JPEG, GIF, PNG, BMP.

- Beépitett memória: 4GB, mely nagyjából 1.000 e-könyv tárolására képes.

- Készülékház színe: fekete

Úgy döntöttél, hogy karácsony alkalmából ezt a barátodat szeretnéd meglepni egy-két e-könyvvel, hogy minél többet használhassa az e-könyv olvasóját.

A Csak egy kattintás webshopot felhasználva vásárold meg az ajándékot a barátodnak. A vásárolt e-könyv le-könyvek összege ne haladja meg a 2.700 Ft-ot.

Vásárlásod során a letöltést válaszd mint szállitási módot és a banki átutalást mint fizetési módot. 
A vásárlásod megvalósítása után majd egy e-mailt kapsz, mely után a saját fiók / letöltések menüpontból le is töltheted a „könyvet” a webshopból. Ebben a letöltött „,könyvben” találod majd a további feladatokat.

\section{VÁSÁRLÁS UTÁNI INSTRUKCIÓK, MELYEKET A VÁSÁRLÓ E- MAILBEN KAPOTT MEG.}

Megrendelésed megérkezett, a kísérlet ezen szakasza befejezödött. A folytatáshoz kérlek, ALAPOSAN OLVASD EL az instrukciókat, melyeket az e-mail tartalmaz, és figyelj, hogy a te esetedben MELYIK INSTRUKCIÓT kell követni. Amennyiben a kisérlet ezen szakaszában E-KÖNYVET kellett vásárolnod, kérjük a webshopban a SAJÁT FIÓKODBAN a RENDELÉSEIM menüpontnál a LETÖLTÉSEK menüpont alól töltsd le a megrendelt e-könyvet, és kövesd a letöltött dokumentumban található instrukciókat.

Amennyiben RUHÁZATI KIEGÉSZÍTŐT kellett ebben a szakaszban vásárolnod, és ez volt az ELSÖ VÁSÁRLÁSOD a kísérlet során (A szcenárió), akkor kövesd az instrukciókat az alábbi linket felhasználva: http://megkerdezes.ebusinessportal.hu/index.php?sid $=81528 \&$ lang $=h u$

Amennyiben a ruházati kiegészitő vásárlása a MÁSODIK VÁSÁRLÁSOD volt a kísérlet során (B szcenárió), kérlek, kövesd az instrukciókat az alábbi linket felhasználva: http://megkerdezes.e-businessportal.hu/index.php?sid=75159\&lang $=h u$ 


\section{Melléklet: A kapcsolódó előtanulmányok eredményei}

Az elmúlt két és fél év során az elektronikus kereskedelemmel kapcsolatos minőség és elégedettség témakörében kettő jelentő kutatás született. Az első során olyan webshopokkal kapcsolatban került sor a minőségészlelés, illetve elégedettség kapcsolatrendszerének vizsgálatára, melyek offline-termékeket értékesítenek. A kutatás során egy online könyvesbolt, valamint egy online-gyógyszertár ügyfélkörét kérdeztük meg. Második kutatásunkkor hallgatói mintát használva teszteltük az összefüggéseket. Ez annyiban mutatott túl az első projekten, hogy itt már nem csak termékek, hanem szolgáltatások online vásárlására is kitértünk, és ennek megfelelően egy olyan skálát használtunk, melyet ilyen körülmények között fejlesztettek ki. Az offline és elektronikus termékek, valamint szolgáltatások megkülönböztetésére azonban ebben a kutatásban sem került sor.

\subsection{Az elektronikus szolgáltatásminőség mérése offline-termékek esetében - 1 . pilot study}

2011 októberében egy hazai online könyvesbolt, valamint egy online gyógyszertár esetében teszteltük az elektronikus szolgáltatásminőség észlelését. A kérdőív fő vázát az E-S-Qual és E-RecS-Qual skálák (Parasumaran et al. 2005) dimenzió adták meg, valamint a bevezető blokk tartalmazott egy a honlaphoz köthető online vásárlási szokásokról szóló rövid kérdéssort is. Az egy hétig tartó lekérdezés során az online könyvesbolt esetében 352 regisztrált ügyfél töltötte ki a kérdőívet, míg az online gyógyszertár esetében 170 fö.

\subsection{A minta}

Az online könyvesbolt esetében a válaszadók többsége $(74,5 \%)$ már több mint egy éve használja a vizsgált honlapot, és csupán 6\%-uk csatlakozott kevesebb, mint 3 hónapja a felhasználók közé. A megkérdezettek 41\%-a havonta legalább 9 alkalommal látgatja az online könyvesbolt weblapját, és csupán 10\%-uk az, aki még sohasem vásárolt a honlapon. A többség (41\%) félévente szokott vásárolni, azonban a havonta legalább egyszer vásárlók aránya is jelentős (39\%). Ezek alapján megállapítható, hogy a mintába valóban olyan egyének kerültek, akik aktív felhasználói a web-shopnak. Utolsó vásárlásukkor a válaszadók átlagosan 5240 Ft-t költöttek. A legnagyobb utolsó költés $30.000 \mathrm{Ft}$ volt (2 válaszadó), 48\%-uk 3-5.000 Ft közötti összeget fizetett, a $8.000 \mathrm{Ft}$ felett 
vásárlók aránya pedig 16,5\%-os. Ez azért fontos, mert a házhozszállítás ekkora összeg felett ingyenes.

\begin{tabular}{|c|c|c|c|}
\hline \multicolumn{2}{|l|}{$\operatorname{Nem}(\mathbf{N}=170$ fó) } & \multicolumn{2}{|l|}{ Mióta használja a honlapot ( $\mathrm{N}=170$ fó) } \\
\hline Férfi & $7 \%$ & Kevesebb mint 3 hónapja & $15 \%$ \\
\hline Nő & $93 \%$ & 3-6 hónapja & $15 \%$ \\
\hline Életkor & & 6-12 hónapja & $15 \%$ \\
\hline 20-29 év & $8 \%$ & Több mint 1 éve & $55 \%$ \\
\hline 30-39 év & $48 \%$ & \multicolumn{2}{|c|}{ Milyen gyakran látogatja a honlapot? (N=170 fó) } \\
\hline $40-49$ év & $18 \%$ & Kevesebb mint 5 alkalommal egy hónapban & $74 \%$ \\
\hline 50 év feletti & $26 \%$ & 5-8 alkalommal havonta & $21 \%$ \\
\hline \multicolumn{2}{|c|}{ Legmagasabb iskolai végzettség $(\mathrm{N}=170$ fó) } & 9-12 alkalommal havonta & $2 \%$ \\
\hline Szakmunkás & $38 \%$ & Többször mint 12 alkalommal havonta & $4 \%$ \\
\hline Középiskolai érettségi & $2 \%$ & \multicolumn{2}{|c|}{ 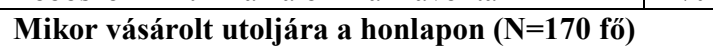 } \\
\hline Föiskolai & $36 \%$ & Kevesebb mint 1 hete & $5 \%$ \\
\hline Egyetemi & $22 \%$ & $1-2$ hete & $8 \%$ \\
\hline Egyéb & $2 \%$ & $2-4$ hete & $14 \%$ \\
\hline \multicolumn{2}{|c|}{ Személyes havi nettó jövedelem (N=170 fó) } & 4-8 hete & $16 \%$ \\
\hline Nettó 50.000 Ft-nál kevesebb & $12 \%$ & Régebben mint 8 hete & $50 \%$ \\
\hline Nettó 50.000-99.999 Ft & $31 \%$ & Még sohasem vásároltam az oldalon. & $8 \%$ \\
\hline Nettó 100.000-149.999 Ft & $25 \%$ & \multicolumn{2}{|c|}{ Milyen gyakran vásárol a honlapon? (N=170 fó) } \\
\hline Nettó $150.000-199.999 \mathrm{Ft}$ & $12 \%$ & Hetente többször & $1 \%$ \\
\hline Nettó $200.000-499.999 \mathrm{Ft}$ & $12 \%$ & Havonta 2-3 alkalommal & $4 \%$ \\
\hline \multirow[t]{3}{*}{ n. válasz } & $8 \%$ & Havonta egyszer & $21 \%$ \\
\hline & & Félévente & $51 \%$ \\
\hline & & Ritkábban mint félévente & $23 \%$ \\
\hline
\end{tabular}

\section{2. táblázat: A minta leíró jellemzői, online-gyógyszertár} Forrás: saját szerkesztés

Az online gyógyszertár esetében a megkérdezettek 55\%-a már több mint egy éve használja a web-shopot, csupán $15 \%$ az, aki kevesebb mint 3 hónapja regisztrált. A többség (73,5\%) havonta kevesebb mint 5 alkalommal látogatja a honlapon, és a válaszadók 50\%-a régebben mint 8 hete vásárolt a weblapon. A legtöbben $(47 \%)$ általában félévente vesznek valamint az oldalon, azonban jelentős a havonta vásárló aránya is (19\%). Az utolsó vásárlásukkor a megkérdezettek átlagosan $8.300 \mathrm{Ft}$-t költöttek. A többség (31\%) 2501-5000 Ft körül költött, 29\%-uk 5001-10.000 Ft között, azonban a $10.000 \mathrm{Ft}$ felett költök aránya is jelentős (19\%). 9,5\% (16 fö) nem válaszolt erre a kérdésre. A minták részletes leíró jellemzőit a 9. és 10. táblázatok tartalmazzák.

\subsection{Eredmények}

Az E-S-QUAL skála összesen 22 kijelentést, a kiegészítő E-RecS-QUAL pedig 11 kijelentést tartalmaz négy, illetve három dimenzióba sorolva, melyeket 1-től 5-ig terjedő skálán kell a kitöltőknek értékelniük az alapján, hogy az adott kijelentéssel a vizsgált honlappal kapcsolatban mennyire értenek egyet (5) vagy sem (1) (4. táblázat).

\begin{tabular}{|l|c|l|c|}
\hline Neme (N=353 fö) & Mióta használja a honlapot? (N=353 fö) \\
\hline Férfi & $14 \%$ & Kevesebb mint 3 hónapja & $6 \%$ \\
\hline Nő & $86 \%$ & 3-6 hónapja & $6 \%$ \\
\hline Életkor (N=353 fö) & & 6-12 hónapja & $14 \%$ \\
\hline 20 év alatti & $10 \%$ & Több mint 1 éve & $75 \%$ \\
\hline
\end{tabular}




\begin{tabular}{|c|c|c|c|}
\hline 20-29 év & $28 \%$ & \multicolumn{2}{|c|}{ Milyen gyakran látogatja a honlapot? ( $\mathrm{N}=353$ fó) } \\
\hline 30-39 év & $33 \%$ & Kevesebb mint 5 alkalommal egy hónapban & $22 \%$ \\
\hline 40-49 év & $16 \%$ & 5-8 alkalommal havonta & $37 \%$ \\
\hline 50 év feletti & $13 \%$ & 9-12 alkalommal havonta & $18 \%$ \\
\hline \multicolumn{2}{|l|}{ 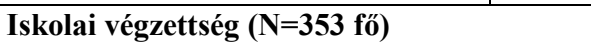 } & Többször mint 12 alkalommal havonta & $24 \%$ \\
\hline Áltanos iskola & $5 \%$ & \multicolumn{2}{|c|}{ Mikor vásárolt utoljára a honlapon? (N=353 fö) } \\
\hline Szakmunkás & $7 \%$ & Kevesebb mint 1 hete & $17 \%$ \\
\hline Középiskolai/Gimnáziumi érettségi & $36 \%$ & $1-2$ hete & $15 \%$ \\
\hline Főiskolai & $27 \%$ & 2-4 hete & $8 \%$ \\
\hline Egyetemi & $22 \%$ & 4-8 hete & $17 \%$ \\
\hline Egyéb & $3 \%$ & Régebben mint 8 hete & $33 \%$ \\
\hline \multicolumn{2}{|l|}{ 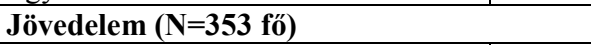 } & Még sohasem vásároltam az oldalon. & $10 \%$ \\
\hline nettó 50.000 Ft-nál kevesebb & $22 \%$ & \multicolumn{2}{|c|}{ Milyen gyakran vásárol a honlapon? (N=353 fó) } \\
\hline nettó 50.000-99.999 Ft & $30 \%$ & Hetente egyszer & $0 \%$ \\
\hline nettó $100.000-149.999 \mathrm{Ft}$ & $18 \%$ & Havonta 2-3 alkalommal & $9 \%$ \\
\hline nettó $150.000-199.999 \mathrm{Ft}$ & $12 \%$ & Havonta egyszer & $30 \%$ \\
\hline nettó $200.000-499.999 \mathrm{Ft}$ & $7 \%$ & Félévente & $42 \%$ \\
\hline nettó $500.000 \mathrm{Ft}$ vagy annál több & $0 \%$ & Ritkábban mint félévente & $19 \%$ \\
\hline n.a. & $11 \%$ & Átlagos utolsó költés & $5240 \mathrm{Ft}$ \\
\hline
\end{tabular}

\section{3. táblázat: A minta leíró jellemzői, online-könyvesbolt}

Forrás: saját szerkesztés

$\mathrm{Az}$ online könyvesbolt esetében a rendszer elérhetőség és teljesítmény dimenzióinak összegzett átlagos értékelése megegyezett $(4,68)$, ezt követi a biztonság $(4,62)$, „leggyengébben” pedig a hatékonyság faktort értékelték a válaszadók $(4,55)$. A kiegészítő skála átlagos értékei ezektől kissé elmaradnak: legjobb értékelést a válaszadó készség dimenzió kapta $(4,4)$, ezt követi a kapcsolat $(4,35)$, majd a kompenzáció $(3,96)$. Az eredmények az online patika esetében is hasonlóan alakultak. A főskála esetében a legjobb értékelést szintén a teljesítmény dimenzió kapta $(4,8)$, melyet az elérhetőség $(4,76)$ és biztonság követnek $(4,74)$, és a hatékonysághoz tartozó minőségészlelés a leggyengébb $(4,65)$. A mellékskála, az E-RecS-Qual esetében a válaszadó-készség és kapcsolat dimenziók értékelése hasonlóan alakult (4,64 és 4,63). Ebben az esetben is leggyengébben a web-shop a kompenzáció dimenzió mentén teljesít $(4,43)$ (11. táblázat). 


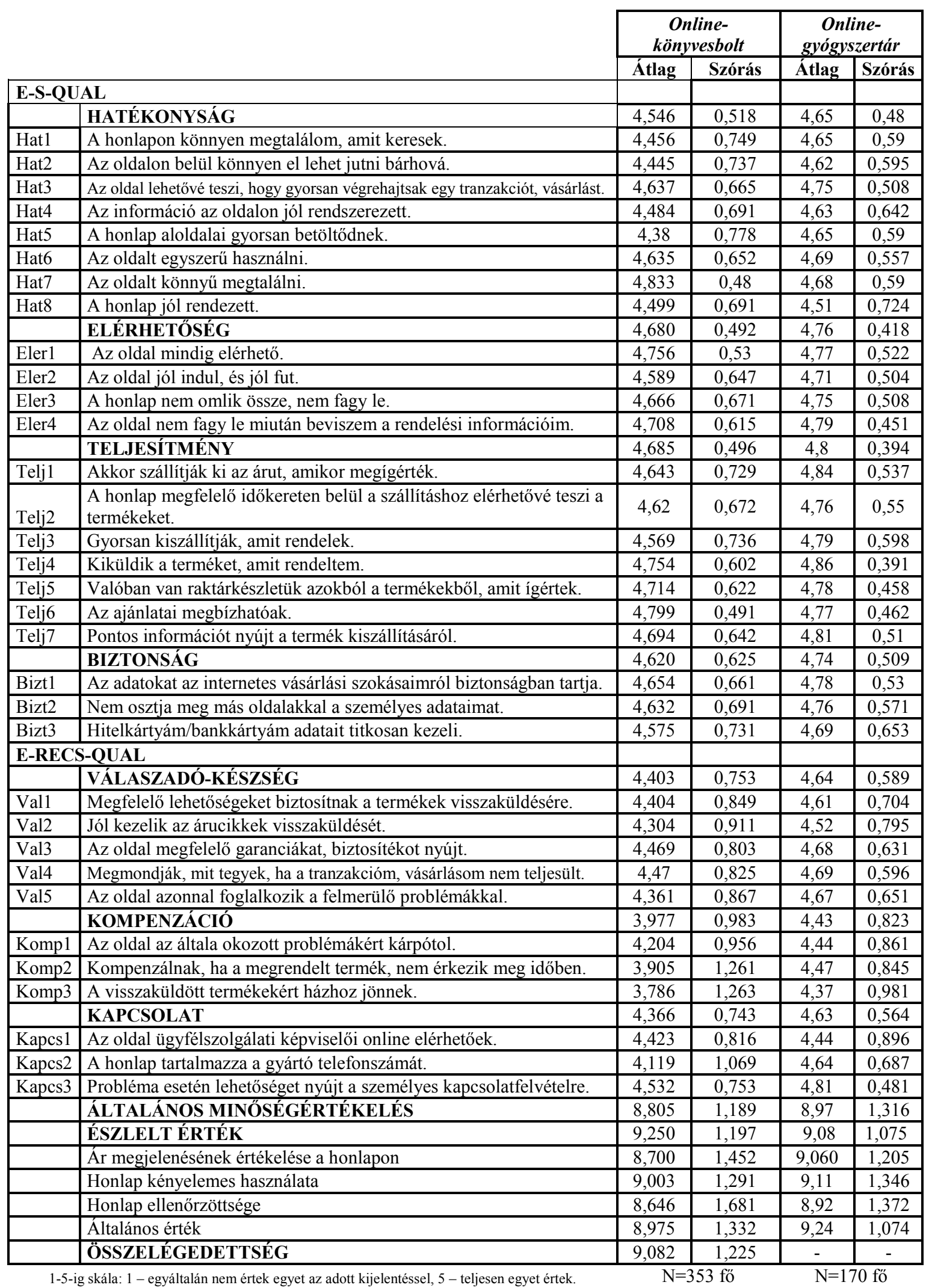

4. táblázat: A mért dimenziók leíró statisztikái (átlag, szórás)

Forrás: eredmények alapján saját szerkesztés

A skála tételeinek megbízhatóságát megvizsgálva megállapítható, hogy a Cronbach-alfa értékek a Nunnaly és Bernstein (1994) által meghatározott szint felettiek (0,721 és 0,927 közötti érték, 12. táblázat). 
Az E-S-QUAL, illetve E-RecS-QUAL skálák dimenzióinak hatását az általános minőségre valamint az észlelt érték kategóriájára PLS út modellezés módszerével vizsgáltuk meg LVPLS programot használva. Az online könyvesbolt esetében az elemzése az elégedettséget is belevettük.

\begin{tabular}{|c|c|c|c|c|c|c|c|c|c|}
\hline & \multicolumn{2}{|c|}{$\begin{array}{c}\text { Teljes korreláció } \\
\text { (korrigált mérési tétel) }\end{array}$} & \multicolumn{2}{|c|}{$\begin{array}{c}\text { Cronbach's Alfa, ha az } \\
\text { itemet töröljük }\end{array}$} & & \multicolumn{2}{|c|}{$\begin{array}{c}\text { Teljes korreláció } \\
\text { (korrigált mérési tétel) }\end{array}$} & \multicolumn{2}{|c|}{$\begin{array}{c}\text { Cronbach's Alfa, ha } \\
\text { az itemet töröljük }\end{array}$} \\
\hline & \multicolumn{2}{|c|}{ Online-könyvesbolt } & \multicolumn{2}{|c|}{ Online-gyógyszertár } & & \multicolumn{2}{|c|}{ Online-könyvesbolt } & \multicolumn{2}{|c|}{ Online-gyógyszertár } \\
\hline \multicolumn{5}{|c|}{ E-S-QUAL } & \multicolumn{5}{|c|}{ Elérhetőség - Cronbach-alfa: 0,807 / 0,862 } \\
\hline Hat1 & 0,507 & 0,768 & 0,921 & 0,905 & Eler2 & 0,606 & 0,677 & 0,918 & 0,837 \\
\hline Hat2 & 0,65 & 0,838 & 0,918 & 0,899 & Eler3 & 0,508 & 0,756 & 0,92 & 0,803 \\
\hline Hat5 & 0,514 & 0,597 & 0,92 & 0,918 & & & & & \\
\hline Hat6 & 0,639 & 0,858 & 0,918 & 0,898 & E-REC & & & & \\
\hline Hat7 & 0,62 & 0,625 & 0,919 & 0,916 & Válasza & - Cronbac & fa: 0,922 & 0,927 & \\
\hline Hat8 & 0,55 & 0,772 & 0,92 & 0,905 & Val1 & 0,826 & 0,824 & 0,94 & 0,907 \\
\hline \multicolumn{5}{|c|}{ Teljesítmény - Cronbach-alfa: 0.894 / 0.878} & Val2 & 0,862 & 0,797 & 0,938 & 0,915 \\
\hline Telj1 & 0,559 & 0,772 & 0,919 & 0,868 & Val3 & 0,813 & 0,863 & 0,94 & 0,9 \\
\hline Telj5 & 0,538 & 0,471 & 0,92 & 0,901 & Komp1 & 0,805 & 0,884 & 0,941 & 0,813 \\
\hline Telj6 & 0,427 & 0,518 & 0,922 & 0,897 & Komp2 & 0,708 & 0,821 & 0,944 & 0,867 \\
\hline Telj7 & 0,674 & 0,785 & 0,917 & 0,867 & Komp3 & 0,635 & 0,759 & 0,947 & 0,927 \\
\hline \multicolumn{5}{|c|}{ Biztonság - Cronbach-alfa: 0,858 / 0,835} & \multicolumn{5}{|c|}{ Kapcsolat - Cronbach-alfa: 0,803 / 0,721} \\
\hline Bizl & 0,535 & 0,765 & 0,92 & 0,716 & Kapcs2 & 0,719 & 0,516 & 0,944 & 0,741 \\
\hline Biz2 & 0,546 & 0,699 & 0,92 & 0,769 & Kapcs1 & 0,702 & 0,644 & 0,945 & 0,509 \\
\hline Biz3 & 0,64 & 0,646 & 0,918 & 0,836 & Kapcs3 & 0,721 & 0,576 & 0,944 & 0,66 \\
\hline
\end{tabular}

\section{5. táblázat: Az E-S-Qual és E-RecS-Qual skálák megbízhatósága}

Forrás: eredmények alapján saját szerkesztés

A PLS útelemzés eredményei alapján megállapítható, hogy az általános észlelt minőséghez kapcsolódó dimenziók közül mindkét esetben a hatékonyság rendelkezik a legnagyobb útegyütthatóval $\left(\beta_{\mathrm{K} 11}=0,6, \beta_{\mathrm{P} 11}=0,74\right)$. Az online könyvesbolt esetében jelentős hatással bír még a válaszadó-készség $\left(\beta_{\mathrm{K} 15}=0,15\right)$ illetve teljesítmény $\left(\beta_{\mathrm{K} 13}=-\right.$ $0,12)$, míg az online gyógyszertárnál a kompenzáció $\left(\beta_{\mathrm{P} 16}=0,24\right)$ illetve teljesítmény $\left(\beta_{\mathrm{P} 13}=-0,20\right)$. Az észlelt érték dimenziójára legnagyobb közvetlen hatással mindkét esetben a hatékonyság $\left(\beta_{\mathrm{K} 21}=0,55, \beta_{\mathrm{P} 21}=0,30\right)$ bír, melyet az online patika esetében a kompenzáció $\left(\beta_{\mathrm{P} 26}=-0,18\right)$, teljesítmény $\left(\beta_{\mathrm{P} 23}=0,16\right)$ válaszadó-készség $\left(\beta_{\mathrm{P} 25}=0,16\right)$ és elérhetőség $\left(\beta_{\mathrm{P} 22}=-0,12\right)$ kategóriák követnek. Az online könyvesbolt esetében jelentős hatással az észlelt értékre csak a válaszadó-készség bír $\left(\beta_{\mathrm{K} 25}=0,26\right)$. Érdekes az útegyütthatók negatív értéke, mely érték a kapcsolat irányának megváltozatásával pozitívvá változtatható. Az exogén manifeszt változók regressziós súlyainak értéke ( $\omega \mathrm{ij})$ 0,5 és 0,96 között mozog, a többszörös négyzetes korrelációs együtthatók értéke pedig az észlelt minőség esetében $\mathrm{R}_{\mathrm{K}}{ }^{2}=0,41$, illetve $\mathrm{R}_{\mathrm{P}}{ }^{2}=0,52$, míg az érték változónál $\mathrm{R}_{\mathrm{K}}{ }^{2}=0,60$, illetve $\mathrm{R}_{\mathrm{P}}{ }^{2}=0,83$. 
Az online könyvesbolt esetében az elemzésbe az elégedettség is bevonásra került. A vizsgált elektronikus szolgáltatásminőség dimenziók közül legjelentősebb direkt hatása a hatékonyságnak $\left(\beta_{\mathrm{K} 31}=0,37\right)$ illetve a válaszadó-készségnek $\left(\beta_{\mathrm{K} 35}=0,15\right)$ van, emellett jelentős a szummázot elégedettség hatása is $\left(\beta_{\mathrm{K} 39}=0,36\right)$. Az elégedettséghez tartozó magyarázóerő $\mathrm{R}_{\mathrm{K}}^{2}=0,6$.

A PhD témámhoz tartozó elsőkörös kutatások során megvizsgáltuk, hogy a Parasuraman és társai (2005) által felállított elektronikus szolgáltatásminőség dimenziói, hogyan alakulnak olyan web-shopok esetében, melyek offline-termékeket értékesítenek, és a különböző faktorok, milyen kapcsolatban állnak az észlelt minőség, érték valamint elégedettség kategóriákkal.

Elemzésünk alapján megállapítható, hogy az észlelt minőséget leginkább a hatékonyság kategória befolyásolja, tehát amennyiben egy offline-terméket értékesítő web-shop a minőségészlelését szeretnék javítani, akkor első körben a honlap használatának egyszerüségre és gyorsaságára kell a hangsúlyt helyezni. A fogyasztók által észlelt értéket szintén a hatékonyság, valamint a válaszadó-készség értékelése befolyásolja leginkább.

A tanulmány egyik limitációja az alacsony elemszám, melyet a PLS útmodellezés használatával megpróbáltuk kiküszöbölni. Emellett jelentősen befolyásolhatta az eredményeinket is az erős jobboldali aszimmetria. Ennek csökkentése érdekében célszerübb lenne 1-7-ig terjedő vagy 11 fokú (0-10) skálát használni, mely talán képes a különbségeket árnyaltabban kifejezni (Füstös, 2009). A tanulmány további korlátja, hogy csak offline-termékek esetében mérte az elektronikus szolgáltatásminőséget.

2.1. Az elektronikus szolgáltatásminőség hatása az elégedettségre, újrahasználatra és továbbajánlásra termékek és szolgáltatások esetében - 2. pilot study

A korábban bemutatott kutatásból kiindulva és korlátjait figyelembe véve 2012 tavaszán egy második, továbbfejlesztett projektet indítottunk el. Ebben már egy olyan szolgáltatásminőség skála került használatra, melyet termékek és szolgáltatások esetében is teszteltek már, és az elégedettség mellett következményeket is tartalmazott, mégpedig a szájreklámot illetve az újra-használati szándékot.

A kutatás során célunk a 30 év alatti fiatalok elérése volt, melyhez hólabda mintavételt alkalmaztunk. A két hétig tartó online megkérdezés során 148 válaszadónk lett, és az ő eredményeik alapján dolgoztunk. A kérdőívben az általános online vásárlási szokások megismerése után került sor a legutolsó vásárláskor használt web-shop értékelésére. 
A szakirodalom alapján az alábbi hipotéziseket állítottuk fel:

H1: Az elektronikus szolgáltatásminőség pozitív hatással bír az elégedettségre.

H1a: A szolgáltatások vásárlása esetében az elektronikus szolgáltatásminőség pozitív hatással bír az elégedettségre.

H1a: A termékek vásárlása esetében az elektronikus szolgáltatásminőség pozitív hatással bír az elégedettségre.

Hivatkozott irodalom: Parasuraman et al. 1985, Cronin - Taylor 1992, Veres 1999, Wolfinbarger - Gilly 2003, Gummerus et al. 2004, Chang 2005, Parasuraman et al. 2005, Bressolles et al. 2007, Yang - Tsai 2007, Godwin et al. 2010

Függö változó: elégedettség - skála: Chang, Wang, és Yang, 2009.

Független változó: elektronikus szolgáltatásminőség - skála: ETAILQ, Wolfinbarger és Gilly, 2003.

H2: Az elektronikus szolgáltatásminőség pozitív hatással az újravásárlási szándékra.

H2a: A szolgáltatások vásárlása esetében az elektronikus szolgáltatásminőség pozitív hatással az újravásárlási szándékra.

H2b: A termékek vásárlása esetében az elektronikus szolgáltatásminőség pozitív hatással az újravásárlási szándékra.

Függö változó: újravásárlási szándék - skála: Godwin, Bagchi és Kirs, 2010.

Független változó: elektronikus szolgáltatásminöség - skála: ETAILQ, Wolfinbarger és Gilly, 2003.

Hivatkozott irodalom: Parasuraman, Zeithaml, és Berry, 1988, 1991, Taylor és Baker, 1994; Zeithaml, Berry, és Parasuraman, 1996, Cronin et al. 2000, Godwin et al. 2010.

H3: Az elektronikus szolgáltatásminőség pozitív hatással a szájreklámra.

H3a: A szolgáltatások vásárlása esetében az elektronikus szolgáltatásminőség pozitív hatással a szájreklámra.

H3b: A termékek vásárlása esetében az elektronikus szolgáltatásminőség pozitív hatással a szájreklámra.

Függő változó: szájreklám - skála: Zeithalm et al. 1996.

Független változó: elektronikus szolgáltatásminőség - skála: ETAILQ, Wolfinbarger és Gilly, 2003.

H4: Az elégedettség pozitív hatással az újravásárlási szándékra.

H4a: A szolgáltatások vásárlása esetében az elégedettség pozitív hatással az újravásárlási szándékra. 
H4b: A termékek vásárlása esetében az elégedettség pozitív hatással az újravásárlási szándékra.

Hivatkozott irodalom: Cronin-Taylor, 1992, Brady-Robertson, 2001, Godwin et al. 2010.

Függö változó: újravásárlási szándék - skála: Godwin, Bagchi és Kirs, 2010.

Független változó: elégedettség - skála: Chang, Wang, és Yang, 2009.

H5: Az elégedettség pozitív hatással a szájreklámra.

H5a: A szolgáltatások vásárlása esetében az elégedettség pozitív hatással a szájreklámra. H5b: A termékek vásárlása esetében az elégedettség pozitív hatással a szájreklámra.

Hivatkozott irodalom: Dolen, Dabholkar, és Buyter 2007, Ltifi és Gharbi 2012.

Függő változó: szájreklám - Zeithalm et al. 1996.

Független változó: elégedettség - skála: Chang, Wang, és Yang, 2009.

\subsection{A minta jellemzői}

A válaszadóink 68\%-a volt nő, többségük a 19-26 éves korosztályba tartozott (91\%) és a fővárosban él (65\%). A mintába kerültek közel fele (44\%) még a felsőoktatásban tanul. A válaszadók többsége ritkábban, mint kéthavonta szokott online vásárolni (45\%), azonban jelentős a havonta interneten vásárlók aránya is (30\%). Legnépszerübb általában vásárolt terméknek a könyvek, valamint a meleg étel számítanak: a válaszadók 17\%, illetve 13\%-a jelölte meg ezeket, míg a szolgáltatások tekintetében a többség mozi-, színház vagy egyéb belépőjegyet (16\%), valamint utazást és repülőjegyet (15\%) szokott az interneten vásárolni.

A megkérdezettek 44\%-ának a legutolsó online vásárlása kevesebb, mint két hete történt, melynek során a többség könyvet (20\%), meleg ételt (16\%), valamilyen belépőjegyet (14\%), vagy repülőjegyet vásárolt (12\%). Összességében a válaszadók 62,5\%-a terméket, míg 37,5\%-uk valamilyen szolgáltatást vett utolsó vásárlása során. Legtöbben kevesebb, mint 5000 Ft-ért vásároltak (58\%), azonban jelentős a 20.0000 Ft vásárlók aránya is (12\%). A megkérdezettek 43\%-a az átvételkor fizetett a megrendelésért, míg 22\%-uk banki átutalással, 34\%-uk pedig bank-, illetve hitelkártyával.

A legutolsó vásárlásukkor terméket vagy szolgáltatást vevők között számos jelentős magatartási szokás figyelhető meg. Akik szolgáltatást vettek legutoljára jellemzően sürübben vásárolnak online ${ }^{21}$, többségük előre fizetett banki átutalással (27\%) vagy

${ }^{21}$ Pearson Chi négyzet sig $=0,050, \mathrm{Phi}=0,233$ 
valamilyen kártyával $(55 \%)^{22}$, valamint jellemzően magasabb összegben történt a legutolsó vásárlásuk: 63\%-uk vásárolt $5000 \mathrm{Ft}$ felett, míg a terméket vevők körében ez mindössze 31\%-ot mutat. (18. táblázat).

\subsection{Eredmények}

Kutatásunk során az elektronikus szolgáltatásminőség hatását kívántuk mérni az elégedettségre, valamint ennek kapcsolatát az újravásárlási szándékkal illetve a szájreklámmal. A kutatás során alkalmazott skálák megfelelő megbízhatósággal rendelkeznek: a Cronbach-alfa értékek a Nunnaly és Bernstein (1994) által meghatározott 0,7 szint felettiek ( 0,795 és 0,931 közötti érték). A mérési tételek korrelációs együtthatói is elfogadhatóak (Churchill, 1979): a teljes mintán a korreláció 0,398 és 0,88 között mozog, csak a szolgáltatást vásárló részminta esetében 0,28 és 0,89 között, míg a termékeknél 0,42 és 0,87 között (13. táblázat).

\begin{tabular}{|c|c|c|c|c|c|c|}
\hline & \multicolumn{2}{|c|}{ Teljes } & \multicolumn{2}{|c|}{ Szolgáltatás } & \multicolumn{2}{|c|}{ Termék } \\
\hline & $\mathbf{R}$ & $\boldsymbol{\alpha}_{\text {mód }}$ & $\mathbf{R}$ & $\boldsymbol{\alpha}_{\text {mód }}$ & $\mathbf{R}$ & $\boldsymbol{\alpha}_{\text {mód }}$ \\
\hline ELEKTRONIKUS SZOLGÁLTATÁSMINŐSÉG (QUAL) & \multicolumn{2}{|c|}{$\alpha=0,874$} & \multicolumn{2}{|c|}{$\alpha=0,767$} & \multicolumn{2}{|c|}{$\alpha=\mathbf{0 , 8 8 3}$} \\
\hline A honlap részletes információkat nyújt. & ,512 &, 867 & ,497 &, 864 & ,547 & ,877 \\
\hline Ez a honlap nem rabolja az időmet. & ,534 & ,866 &, 583 & ,860 & ,503 & ,879 \\
\hline $\begin{array}{l}\text { A honlapon gyorsan és könnyen végre lehet hajtani a } \\
\text { tranzakciókat. }\end{array}$ &, 549 &, 864 &, 592 & ,859 &, 517 & ,877 \\
\hline $\begin{array}{l}\text { A honlap személyre szabhatóságának szintje éppen } \\
\text { megfelelő: nem túl nagy, de nem is túlságosan korlátozott }\end{array}$ &, 526 &, 866 &, 574 & ,860 & ,494 & ,879 \\
\hline A honlap választéka jónak mondható. & ,497 & ,867 & ,530 & ,863 & 470 & ,879 \\
\hline A küldött termék/szolgáltatás a honlapon látottal azonos. &, 507 & ,867 &, 572 &, 863 & ,499 & ,878 \\
\hline $\begin{array}{l}\text { Erről a honlapról pontosan azt a terméket/szolgáltatást } \\
\text { kapom, amit megrendeltem. }\end{array}$ & ,419 &, 871 & 410 &, 869 & ,442 & ,880 \\
\hline $\begin{array}{l}\text { A cég a megrendelt terméket/szolgáltatást a megígért időben } \\
\text { szállítja/teljesíti. }\end{array}$ & ,398 &, 872 & ,285 & ,872 &, 524 & ,877 \\
\hline $\begin{array}{l}\text { Úgy vélem, az adataim ezen a web-helyen biztonságban } \\
\text { vannak. }\end{array}$ &, 507 & ,867 &, 544 & ,862 &, 501 & ,878 \\
\hline A honlapon a tranzakcióimat biztonságosnak érzem. & ,596 & ,862 & ,665 & ,855 & ,562 &, 875 \\
\hline $\begin{array}{l}\text { A honlap megfelelő mértékủ biztonsággal van ellátva a } \\
\text { tranzakciók kezeléséhez. }\end{array}$ &, 585 &, 863 &, 514 &, 863 & 657 & ,870 \\
\hline A cég készséggel és gyorsan reagál a vevők igényeire. & ,619 & $\begin{array}{ll}, 861 \\
\end{array}$ & 518 & ,865 & ,746 & ,865 \\
\hline $\begin{array}{l}\text { Probléma felmerülése esetén úgy érzem, a honlap őszintén } \\
\text { próbálja megoldani azt. }\end{array}$ & 630 &, 860 &, 598 &, 859 & ,656 &, 870 \\
\hline $\begin{array}{l}\text { A felmerülő kérdések a cég részéről azonnal megválaszolásra } \\
\text { kerülnek. }\end{array}$ & ,647 &, 859 & ,610 &, 858 & ,716 & ,867 \\
\hline ELÉGEDETTSÉG (CSAT) & \multicolumn{2}{|c|}{$\alpha=0,931$} & \multicolumn{2}{|c|}{$\alpha=\mathbf{0 , 9 3 1}$} & \multicolumn{2}{|c|}{$\alpha=0,931$} \\
\hline $\begin{array}{l}\text { Elégedett vagyok a döntésemmel, hogy ezen az oldalon } \\
\text { vásároltam. }\end{array}$ & ,882 &, 880 & ,899 &, 867 & ,869 & ,895 \\
\hline $\begin{array}{l}\text { Ha újra vásárolnék ezen a helyen, valószínüleg ugyanúgy } \\
\text { értékelném a honlapot/céget. }\end{array}$ &, 854 & ,902 & ,864 & ,896 & 847 & ,911 \\
\hline Bölcs döntés volt ezen az oldalon vásárolni. & ,837 & ,915 & ,817 & ,933 & ,864 &, 896 \\
\hline ÚJRAVÁSÁRLÁSI SZÁNDÉK (BI) & \multicolumn{2}{|c|}{$\alpha=\mathbf{0 , 8 0 8}$} & \multicolumn{2}{|c|}{$\alpha=0,749$} & \multicolumn{2}{|c|}{$\alpha=\mathbf{0 , 8 4 0}$} \\
\hline A jövőben is gyakran szándékozok ezen a honlapon vásárolni. & ,664 &, 737 & ,593 &, 655 & ,707 &, 780 \\
\hline Biztosan fogok még vásárolni ezen a helyen. . & ,719 & 670 & ,659 &, 572 & ,760 & ,720 \\
\hline $\begin{array}{l}\text { Ha ismét szükségem lesz ilyen jellegú termékre/szolgáltatásra, } \\
\text { ezt a helyet szándékozom újra használni. }\end{array}$ & ,606 & ,792 & ,497 & ,752 & ,666 & ,820 \\
\hline SZÁJREKLÁM (WOM) & \multicolumn{2}{|c|}{$\alpha=\mathbf{0 , 8 8 5}$} & \multicolumn{2}{|c|}{$\alpha=\mathbf{0 , 8 7 9}$} & \multicolumn{2}{|c|}{$\alpha=\mathbf{0 , 8 9 5}$} \\
\hline Erről a cégről/oldalról másoknak pozitív dolgokat mondok. & ,712 &, 895 & ,669 & ,923 & ,754 &, 883 \\
\hline
\end{tabular}

${ }^{22}$ Pearson Chi négyzet sig $=0,000, \mathrm{Phi}=0,450$ 
Ajánlanám az oldalt azoknak, akik kíváncsiak a tanácsomra. Bátorítanám a barátaimat és rokonaimat, hogy használják ezt az oldalt.

$R$-teljes korreláció

$\alpha_{\text {mód }}$-Cronbach-alfa változása, ha a mérési tételt töröljük

3. táblázat: Az alkalmazott skálák megbízhatósága

Forrás: eredmények alapján saját szereksztés

Mind a szolgáltatást, mind pedig a terméket vásárlók körében az e-szolgáltatásminőség dimenziói közül 1-től 7-ig skálán a legjobb átlagos értékelést a megbízhatósághoz tartozik (átlag $\mathrm{msZ}=6,6$, átlag $\mathrm{mT}_{\mathrm{T}}=6,3$ ). A szolgáltatást vásárlók körében leggyengébben a vevőszolgálat dimenziói szerepelt (átlag $\mathrm{vszSZ}=4,8$ ), míg a termékeknél a maradék három dimenzió értékelése hasonló értéket mutat (átlag ${ }_{\mathrm{vsz}}=5,5$, átlag $_{\mathrm{bT}}=5,6$, átlag $\left._{\mathrm{dT}}=5,8\right) . \mathrm{Az}$ elégedettség, újravásárlási szándék, valamint továbbajánlás változók átlagos értékelés mindkét csoportban hasonlóan alakul (14. táblázat):

\begin{tabular}{|c|c|c|c|c|c|c|}
\hline & \multicolumn{2}{|c|}{$\begin{array}{c}\text { Teljes } \\
\left(N=148 f_{o}^{\prime \prime}\right)\end{array}$} & \multicolumn{2}{|c|}{$\begin{array}{l}\text { Szolgáltatás } \\
\left(N=56 f_{o ̈}^{\prime \prime}\right)\end{array}$} & \multicolumn{2}{|c|}{$\begin{array}{c}\text { Termék } \\
(N=92 \text { fó) }\end{array}$} \\
\hline & Átlag & Szórás & Átlag & Szórás & Átlag & Szórás \\
\hline ELEKTRONIKUS SZOLGÁLTATÁSMINŐSÉG & 5,78 & & 5,73 & & 5,82 & \\
\hline Design & 5,73 & & 5,61 & & $\mathbf{5 , 8 0}$ & \\
\hline A honlap részletes információkat nyújt. & 5,97 & 1,043 & 5,75 & 1,297 & 6,11 & ,831 \\
\hline Ez a honlap nem rabolja az időmet. & 5,57 & 1,561 & 5,55 & 1,595 & 5,58 & 1,549 \\
\hline $\begin{array}{l}\text { A honlapon gyorsan és könnyen végre lehet hajtani a } \\
\text { tranzakciókat. }\end{array}$ & 6,12 & 1,277 & 6,05 & 1,367 & 6,16 & 1,225 \\
\hline $\begin{array}{l}\text { A honlap személyre szabhatóságának szintje éppen } \\
\text { megfelelő: nem túl nagy, de nem is túlságosan korlátozott }\end{array}$ & 4,80 & 1,475 & 4,68 & 1,454 & 4,87 & 1,491 \\
\hline A honlap választéka jónak mondható. & 6,18 & 1,030 & 6,02 & 1,152 & 6,28 & 941 \\
\hline Megbízhatóság & 6,42 & & 6,63 & & 6,29 & \\
\hline A küldött termék/szolgáltatás a honlapon látottal azonos. & 6,45 & ,999 & 6,61 & ,888 & 6,36 & 1,054 \\
\hline $\begin{array}{l}\text { Erről a honlapról pontosan azt a terméket/szolgáltatást } \\
\text { kapom, amit megrendeltem. }\end{array}$ & 6,61 & ,805 & 6,70 &, 711 & 6,55 & ,856 \\
\hline $\begin{array}{l}\text { A cég a megrendelt terméket/szolgáltatást a megígért } \\
\text { időben szállítja/teljesíti. }\end{array}$ & 6,19 & 1,174 & 6,57 &, 850 & 5,96 & 1,283 \\
\hline Biztonság & 5,74 & & $\mathbf{5 , 8 9}$ & & 5,66 & \\
\hline $\begin{array}{l}\text { Úgy vélem, az adataim ezen a web helyen biztonságban } \\
\text { vannak. }\end{array}$ & 5,75 & 1,334 & 5,91 & 1,431 & 5,65 & 1,270 \\
\hline A honlapon a tranzakcióimat biztonságosnak érzem. & 5,86 & 1,345 & 5,96 & 1,388 & 5,79 & 1,322 \\
\hline $\begin{array}{l}\text { A honlap megfelelö mértékü biztonsággal van ellátva a } \\
\text { tranzakciók kezeléséhez. }\end{array}$ & 5,62 & 1,242 & 5,79 & 1,289 & 5,52 & 1,209 \\
\hline Vevőszolgálat & 5,25 & & $\mathbf{4 , 8 0}$ & & $\mathbf{5 , 5 2}$ & \\
\hline A cég készséggel és gyorsan reagál a vevők igényeire. & 5,41 & 1,586 & 4,88 & 1,820 & 5,73 & 1,335 \\
\hline $\begin{array}{l}\text { Probléma felmerülése esetén úgy érzem, a honlap } \\
\text { őszintén próbálja megoldani azt. }\end{array}$ & 5,36 & 1,396 & 5,09 & 1,481 & 5,53 & 1,321 \\
\hline $\begin{array}{l}\text { A felmerülő kérdések a cég részéröl azonnal } \\
\text { megválaszolásra kerülnek. }\end{array}$ & 4,97 & 1,512 & 4,45 & 1,683 & 5,29 & 1,305 \\
\hline ELÉGEDETTSÉG & 6,36 & & 6,38 & & 6,36 & \\
\hline $\begin{array}{l}\text { Elégedett vagyok a döntésemmel, hogy ezen az oldalon } \\
\text { vásároltam. }\end{array}$ & 6,38 & 1,103 & 6,41 & 1,332 & 6,36 & ,944 \\
\hline $\begin{array}{l}\text { Ha újra vásárolnék ezen a helyen, valószínüleg ugyanúgy } \\
\text { értékelném a honlapot/céget. }\end{array}$ & 6,38 & 1,145 & 6,45 & 1,306 & 6,34 & 1,041 \\
\hline Bölcs döntés volt ezen az oldalon vásárolni. & 6,34 & 1,104 & 6,29 & 1,232 & 6,37 & 1,024 \\
\hline ÚJRAVÁSÁRLÁSI SZÁNDÉK & 6,01 & & 5,98 & & 6,03 & \\
\hline $\begin{array}{l}\text { A jövőben is gyakran szándékozok ezen a honlapon } \\
\text { vásárolni. }\end{array}$ & 5,68 & 1,424 & 5,54 & 1,388 & 5,77 & 1,446 \\
\hline Biztosan fogok még vásárolni ezen a helyen. . & 6,25 & 1,314 & 6,36 & 1,212 & 6,18 & 1,374 \\
\hline $\begin{array}{l}\text { Ha ismét szükségem lesz ilyen jellegű termékre/ } \\
\text { szolgáltatásra, ezt a helyet szándékozom újra használni. }\end{array}$ & 6,10 & 1,135 & 6,05 & 1,135 & 6,13 & 1,141 \\
\hline SZÁJREKLÁM & 5,87 & & 5,73 & & 5,95 & \\
\hline
\end{tabular}




\begin{tabular}{|c|c|c|c|c|c|c|}
\hline $\begin{array}{l}\text { Erről a cégről/oldalról másoknak pozitív dolgokat } \\
\text { mondok. }\end{array}$ & 5,74 & 1,341 & 5,41 & 1,385 & 5,95 & 1,278 \\
\hline $\begin{array}{l}\text { Ajánlanám az oldalt azoknak, akik kíváncsiak a } \\
\text { tanácsomra. }\end{array}$ & 6,04 & 1,217 & 5,91 & 1,210 & 6,12 & 1,221 \\
\hline $\begin{array}{l}\text { Bátorítanám a barátaimat és rokonaimat, hogy használják } \\
\text { ezt az oldalt. }\end{array}$ & 5,82 & 1,340 & 5,86 & 1,299 & 5,79 & 1,371 \\
\hline
\end{tabular}

4. táblázat: A kutatásban felhasznált változók átlagos értékelése Forrás: eredmények alapján saját szerkesztés

Hipotéziseink tesztelésére SmartPLS programot használtunk. Ennek oka, hogy a PLS útelemzés akkor is használható, ha az eloszlás ferde (Bagozzi - Yi 1994, in: Henseler 2010), mivel nincsen az eloszlásra feltétel (Fornell - Bookstein 1982, in: Henseler 2010), valamint kiküszöböli a kis mintából adódó hibákat is (Henseler et al. 2009). A variancia alapú modellalkotás az elmúlt időszakban egyre népszerübb a marketing területén is: 1987 és 2007 között az 5 legfontosabb marketing szaklapban 20 ilyen jellegü kutatás jelent meg (Eggert 2007).

A modellünket külön teszteltük a szolgáltatások, valamint termékek esetében is. Az eredmények értelmezése előtt azonban meg kell nézni a különböző érvényességi mutatókat, úgy, mint az belső megbízhatóságét (internal consistency reliability), indikátor megbízhatóságét, hasonlósági érvényességét (convergence validity), valamint a különbözőségi érvényességét (discriminant validity).

A belső megbízhatóságot a Cronbach-alfa illetve Dillon-Goldstein's Rho féle mutatóval mérhetjük. A Cronbach-alfa értékek a korábban bemutatottaknak megfelelően 0,7-nél magasabb érétket vesznek fel, kivétel a meghízhatóság dimenzió, és Dillon-Goldstein‘s Rho-féle összetétel megbízhatóság mutató értéke is minden egyes esetben 0,82 feletti értéket mutat. Ezek alapján megfelelő a látens változók belső megbízhatóságát.

\begin{tabular}{|c|c|c|c|c|c|c|}
\hline & Szolgáltatás & Termék & Szolgáltatás & Termék & Szolgáltatás & Termék \\
\hline & \multicolumn{2}{|c|}{$\begin{array}{c}\text { Átlagos magyarázott } \\
\text { variancia } \\
\end{array}$} & \multicolumn{2}{|c|}{$\begin{array}{c}\begin{array}{c}\text { Dillon-Goldstein's } \\
\text { Rho }\end{array} \\
\end{array}$} & \multicolumn{2}{|c|}{ Cronbach-alfa } \\
\hline Vevőszolgálat & 0,7813 & 0,7494 & 0,9146 & 0,8997 & 0,8599 & 0,8325 \\
\hline Design & 0,528 & 0,4856 & 0,8475 & 0,8243 & 0,7736 & 0,7322 \\
\hline Megbízhatóság & 0,6252 & 0,6125 & 0,8256 & 0,8252 & 0,683 & 0,6823 \\
\hline Biztonság & 0,8244 & 0,7231 & 0,9336 & 0,8866 & 0,8926 & 0,8087 \\
\hline $\begin{array}{l}\text { Észlelt minőség } \\
\text { (másodlagos fogalom) }\end{array}$ & 0,5753 & 0,6175 & 0,7886 & 0,7414 & 0,8753 & 0,875 \\
\hline Elégedettség & 0,8639 & 0,8733 & 0,9501 & 0,9539 & 0,9223 & 0,9275 \\
\hline Újravásárlási szándék & 0,6712 & 0,7502 & 0,8596 & 0,9 & 0,7634 & 0,8377 \\
\hline Szájreklám & 0,8158 & 0,8209 & 0,9299 & 0,9321 & 0,8859 & 0,8907 \\
\hline Elvárt érték & \multicolumn{2}{|c|}{$\begin{array}{c}\text { AVE }>0,5 \\
\text { (Fornell - Larcker 1981) }\end{array}$} & \multicolumn{2}{|c|}{$\begin{array}{c}\text { D-G-R >0,7 } \\
\text { (Vandenbosch 1996) }\end{array}$} & \multicolumn{2}{|c|}{$\begin{array}{c}\alpha>0,7 \\
\text { (Nunnaly }- \text { Bernstein 1994) }\end{array}$} \\
\hline
\end{tabular}

5. táblázat: a használt skálák érvényességi mutatói

Forrás: eredmények alapján saját szereksztés 
A látens változókhoz tartozó hasonlósági érvényesség az átlagos magyarázott variancia értékkel mérhető, amely megmutatja, hogy „a skála és ugyanannak a fogalomnak más mérési tételei között mennyiben áll fenn pozitív korreláció" (Malhotra - Simon, 2008, 320. old). Fornell és Larcker (1981) véleménye alapján 0,5 felett fogadható el az érték. Ez a termékek esetében a design dimenzió kivételével minden egyes változó esetében fennáll. ${ }^{23}$ (15. táblázat).

A különbözőségi érvényesség azt mutatja, hogy a skála nem korrelál-e más fogalmak kéréseivel. Ennek ellenőrzésére a Fornell-Larcker kritériumot használjuk, mely szerint egy látenshez tartozó AVE magasabb kell, hogy legyen, mint a bármely más látenssel alkotott korrelációs négyzetösszeg. Egyetlen egy esetben nem felelünk meg ennek a kritériumnak, az észlelt minőség és design dimenziók esetében. Ennek az ellenállásnak a csökkentése érdekében a legalacsonyabb faktorsúllyal rendelkező mérési tételt a design esetében törölni kellene.

Az eredmények azt mutatják, hogy egyes változók esetében az érvényességi mutatók nem megfelelően alakulnak. Elemzésünkhöz validált skálákat használtuk, melyek módosításához sokkal több megalapozásra van szüksége, ezért ezeknek a kritériumoknak a nem teljesülésétől, és a skálák módosításától most eltekintünk.

A két minta esetében a látens endogén változók magyarázott varianciája eltérő. Míg a szolgáltatások esetében az szájreklám magyarázott varianciája 52,3\%, addig a termékek esetében ez mindössze 38,5\%, míg az újravásárlási szándék valamint elégedettség varianciája a termékek esetében magasabb $\left(\mathrm{R}^{2}{ }_{\mathrm{biT}}=0,547, \mathrm{R}^{2}{ }_{\mathrm{sat}}=0,371\right)$. A szolgáltatások esetében az elégedettség varianciájának mindössze 3,4\%-a kerül magyarázatra, ami nagyon alacsony értéknek számít.

A strukturális modell értékelése szempontjából a Cohen-féle mutató használ (1988), mely mutatja, hogy egy kapcsolat, vagyis út megszüntetésével, hogy alakul egy endogén változó magyarázott varianciája. Az f mutató értéke, ha 0,35-nál nagyobb, akkor az adott hatás jelentős az endogén változó szempontjából, vagyis jelentősen hozzájárul a magyarázott varianciahányad növeléséhez. Amennyiben 0,15-0,35 között, akkor közepes, míg 0,02-0,15 között gyenge hatásról beszélünk (Cohen 1988).

\footnotetext{
${ }^{23}$ Mivel a minőség egy másodlagos fogalom, ezért itt kézzel kellett kiszámolni ezt az értéket (MacKenzie et al. 2011).
} 


$$
f^{2}=\frac{\mathrm{R}_{\text {included }}^{2}-\mathrm{R}_{\text {excluded }}^{2}}{1-\mathrm{R}_{\text {included }}^{2}}
$$

ahol $\mathrm{R}^{2}$ included a négyzetes korrelációs együttható a vizsgált kapcsolatot tartalmazó modell

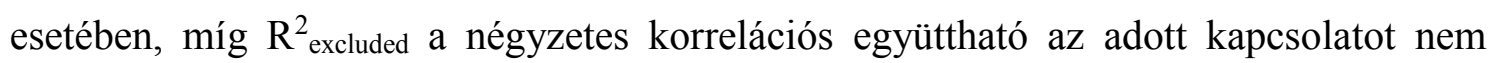
tartalmazó modell esetében.

Az $\mathrm{f}^{2}$ mutató alapján megállapítható, hogy a szolgáltatások esetében az észlelt minőség jelentősen befolyásolja a szájreklám magyarázott varianciájának alakulását ( $\mathrm{f}_{\text {qual- }}^{2}$ womsz $=0,68)$, vagyis a strukturális szintet, azonban a termékek esetében jelentéktelen a hatása ( $\left.\mathrm{f}_{\text {qual-womT }}^{2}=0,03\right)$. A minőség befolyása az újravásárlásra magyarázatában mindkét esetben igen gyenge $\left(\mathrm{f}^{2}\right.$ qual-bisz $\left.=0,14, \mathrm{f}_{\text {qual-biT }}=0,00\right)$. Az elégedettség hatása a szájreklám látens endogén magyarázatában mindkét esetben közepes $\left(\mathrm{f}^{2}{ }_{\text {sat-womsz }}=0,21, \mathrm{f}^{2}{ }_{\text {sat- }}\right.$ womT $=0,25)$, míg az újravásárlással kapcsolatban a szolgáltatásoknál gyenge, a termékeknél pedig nagyon erős ( $\left.\mathrm{f}_{\text {sat-biSz }}=0,11, \mathrm{f}_{\text {sat-biT }}^{2}=0,71\right)(16$. táblázat),

\begin{tabular}{|l|c|c|}
\cline { 2 - 3 } \multicolumn{1}{c|}{} & \multicolumn{2}{c|}{ f2 mutató } \\
\cline { 2 - 3 } \multicolumn{1}{c|}{} & Szolgáltatás & Termék \\
\hline Qual - BI & 0,14 & 0,00 \\
\hline Qual - WOM & 0,68 & 0,03 \\
\hline Sat - BI & 0,11 & 0,71 \\
\hline Sat - WOM & 0,21 & 0,25 \\
\hline
\end{tabular}

6. tábla: A változók közti hatások jelentősége

Forrás: eredmények alapján saját szerkesztés

Az útegyütthatók értelmezése kapcsán elmondató, hogy a szolgáltatások esetében az észlelt elektronikus szolgáltatásminőség jelentős hatással bír az újravásárlási szándékra $\left(\beta_{57 \mathrm{SZ}}=0,351\right)$, valamint szájreklámra $\left(\beta_{58 \mathrm{SZ}}=0,586\right)$, míg az elégedettséghez kapcsolódó hatás elég gyenge $\left(\beta_{56 \mathrm{SZ}}=0,185\right)$. Ebben az esetben az elégedettség mind az újravásárlási szándékra $\left(\beta_{67 \mathrm{Sz}}=0,305\right)$, mind pedig a szájreklámra $\left(\beta_{68 \mathrm{SZ}}=0,329\right)$ jelentős hatást gyakorol. Ezzel szemben a termékek esetében az észlelt minőség csak az elégedettségre bír jelentős hatással $\left(\beta_{55 \mathrm{~T}}=0,609\right)$, és az újravásárlási szándékot, valamint szájreklámot csak az elégedettség befolyásolja jelentősen $\left(\beta_{67 \mathrm{~T}}=0,713, \beta_{68 \mathrm{~T}}=0,498\right)$.

Arról, hogy a különböző útegyütthatók jelentősek-e a következő hipotézist állítjuk fel:

H0: $\beta=0$, vagyis szignifikánsan nem különbözik 0 -tól az adott együttható értéke.

$\mathrm{H} 1: \beta \neq 0$ 
Amennyiben megvizsgáljuk a különböző útegyütthatókhoz tartozó szignifikancia szinteket is megállapítható, hogy a szolgáltatások esetében a 95\%-os megbízhatósági szinten az összes útegyüttható szignifikánsan különbözik 0-tól (H0-t elutasítjuk), 99\%-os megbízhatóság mellett azonban a minőség és elégedettség közti útegyütthatóról ez nem mondható el. A termékek esetében 95\%-os megbízhatósági szinten a minőség hatása az újravásárlásra valamint szájreklámra azonban nem tér el szignifikánsan a 0-tól (H0-t nem utasítjuk el). Ezek alapján a felállított hipotézisek vizsgálata a következőképpen alakul (17. táblázat)

\begin{tabular}{|c|c|c|}
\hline & $\begin{array}{c}\text { 95\%-os } \\
\text { megbízhatóság }\end{array}$ & $\begin{array}{c}\text { 99\%-os } \\
\text { megbízhatóság }\end{array}$ \\
\hline $\begin{array}{l}\text { H1a: A szolgáltatások vásárlása esetében az elektronikus } \\
\text { szolgáltatásminöség pozitív hatással bír az elégedettségre. }\end{array}$ & 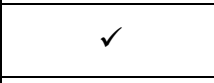 & 凶 \\
\hline $\begin{array}{l}\text { H1b: A termékek vásárlása esetében az elektronikus szolgáltatásminőség } \\
\text { pozitív hatással bír az elégedettségre. }\end{array}$ & $\checkmark$ & $\checkmark$ \\
\hline $\begin{array}{l}\text { H2a: A szolgáltatások vásárlása } \begin{array}{c}\text { esetében } \\
\text { szolgáltatásminőség pozitív hatással az újravásárlási szándékra. }\end{array} \\
\text { elektronikus }\end{array}$ & $\checkmark$ & $\checkmark$ \\
\hline $\begin{array}{l}\text { H2b: A termékek vásárlása esetében az elektronikus szolgáltatásminöség } \\
\text { pozitiv hatással az újravásárlási szándékra. }\end{array}$ & 凶 & 凶 \\
\hline $\begin{array}{l}\text { H3a: A szolgáltatások vásárlása esetében } \\
\text { szolgáltatásminőség pozitív hatással a szájreklámra. }\end{array}$ & $\checkmark$ & $\checkmark$ \\
\hline $\begin{array}{l}\text { H3b: A termékek vásárlása esetében az elektronikus szolgáltatásminöség } \\
\text { pozitiv hatással a szájreklámra. }\end{array}$ & 凶 & 凶 \\
\hline $\begin{array}{l}\text { H4a: A szolgáltatások vásárlása esetében az elégedettség pozitív hatással az } \\
\text { újravásárlási szándékra. }\end{array}$ & $\checkmark$ & $\checkmark$ \\
\hline $\begin{array}{l}\text { H4b: A termékek vásárlása esetében az elégedettség pozitív hatással az } \\
\text { újravásárlási szándékra. }\end{array}$ & $\checkmark$ & $\checkmark$ \\
\hline $\begin{array}{l}\text { H5a: A szolgáltatások vásárlása esetében az elégedettség pozitív hatással a } \\
\text { szájreklámra. }\end{array}$ & $\checkmark$ & $\checkmark$ \\
\hline $\begin{array}{l}\text { H5b: A termékek vásárlása esetében az elégedettség pozitív hatással a } \\
\text { szájreklámra. }\end{array}$ & $\checkmark$ & $\checkmark$ \\
\hline
\end{tabular}

7. táblázat: A hipotézisvizsgálat eredményei

Forrás: eredmények alapján saját szerkesztés

\subsection{Konklúzió}

A második pilot study-ban az elektronikus szolgáltatásminőség, elégedettség, újravásárlási szándék és továbbajánlás kapcsolatrendszerét kívántunk megvizsgálni termékek, valamint szolgáltatások online vásárlása esetében. A változók mérésére validált skálákat használtunk, és az alacsony mintaelem-szám miatt a PLS útelemzés módszerét alkalmaztuk. Eredményeik alapján a felállított hipotézisek többsége támogatásra került, azonban a jövőben a minőség direkt hatását az elégedettség következményeire, úgy mint az újravásárlási szándékra, valamint szájreklámra, az alacsony útegyütthatók miatt nem célszerü vizsgálni, és érdemes lenne az elégedettségen át kifejtett hatást alapul venni, melyet szintén számos korábbi tanulmány alátámaszt (Anderson - Sullivan 1993; Gotlieb, Grewal, Brown 1994; Patterson - Spreng 1997; 
Roest - Pieters, 1997; Taylor 1997). PhD kutatásom megkezdésekor tehát az elégedettség mediáló hatását feltételezem a fentebb említett kapcsolatrendszerben.

A pilot study további kritikája, melyet már az elméleti összefoglalóban is megfogalmaztam az alkalmazott ETAILQ skálával kapcsolatban, hogy az elektronikustermékek és szolgáltatások vásárlása esetében nem méri tökéletesen az elektronikus szolgáltatásminőség dimenzióját. Erre sokkal alkalmasabb az RECIPE skála (Francis 2009), melynek mind a négy e-kereskedelmi kategóriára érvényes validált változata létezik.

Az eredmények értelmezésekor nem szabad azt sem figyelmen kívül hagyni, hogy igen alacsony volt a minta-elemszám, ezért a fontosabb, általánosítható konklúziók levonásához egy sokkal nagyobb elemszámú kutatás szükséges.

Ezeknek a limitációknak a figyelembevételével készítettem el a korábban bemutatott $\mathrm{PhD}$ kutatási tervemet. 


\begin{tabular}{|c|c|c|c|c|c|c|c|}
\hline & Teljes & Szolg & Termék & & Teljes & Szolg & Termék \\
\hline Nem & $N=148 f^{\prime \prime}$ & $N=56 f_{0}^{\prime \prime}$ & $N=92 f^{\prime \prime \prime}$ & Mikor vásároltál utoljára az interneten & $N=148 f^{\prime \prime}$ & $N=56 f^{\prime \prime \prime}$ & $N=92 f^{\prime \prime}$ \\
\hline Férfi & $32 \%$ & $30 \%$ & $34 \%$ & Kevesebb mint 8 napja & $23 \%$ & $25 \%$ & $22 \%$ \\
\hline Nö & $68 \%$ & $70 \%$ & $64 \%$ & 8-14 napja & $21 \%$ & $23 \%$ & $20 \%$ \\
\hline Életkor & $N=148 f^{\prime \prime}$ & $N=56 f_{o}^{\prime \prime}$ & $N=92 f^{\prime \prime}$ & 15-21 napja & $11 \%$ & $9 \%$ & $12 \%$ \\
\hline $19-22$ év & $44 \%$ & $40 \%$ & $47 \%$ & 22-30 napja & $13 \%$ & $14 \%$ & $13 \%$ \\
\hline $23-26$ év & $47 \%$ & $57 \%$ & $41 \%$ & Régebben mint 30 napja & $32 \%$ & $29 \%$ & $33 \%$ \\
\hline $27-30$ év & $9 \%$ & $4 \%$ & $12 \%$ & Mit vásároltál legutolsó vásárlásodkor? & $N=145 f^{\prime \prime}$ & $N=56 f^{\prime \prime}$ & $N=91 f^{\prime \prime}$ \\
\hline Legmagasabb iskolai végzettség & $N=148 f^{\prime \prime}$ & $N=56 f_{o}^{\prime \prime}$ & $N=92 f_{o}^{\prime \prime}$ & könyv & $20 \%$ & & $32 \%$ \\
\hline OKJ vagy felsőfokú szakképzés & $18 \%$ & $13 \%$ & $22 \%$ & meleg étel & $16 \%$ & & $27 \%$ \\
\hline Felsőoktatásban tanulok még & $44 \%$ & $46 \%$ & $42 \%$ & színház, mozi, egyéb belépöjegy & $14 \%$ & $36 \%$ & \\
\hline Föiskola, BA & $21 \%$ & $27 \%$ & $17 \%$ & repülöjegy & $12 \%$ & $32 \%$ & \\
\hline Egyetem, MA & $17 \%$ & $14 \%$ & $19 \%$ & ruházat, sporteszköz & $7 \%$ & & $11 \%$ \\
\hline Lakkhely & $N=148 f^{\prime \prime}$ & $N=56 f_{o}^{\prime \prime}$ & $N=92 f^{\prime \prime \prime}$ & buszjegy, vonatjegy & $6 \%$ & $16 \%$ & \\
\hline Főváros & $65 \%$ & $73 \%$ & $61 \%$ & elektronikai berendezés & $5 \%$ & & $8 \%$ \\
\hline Megyeszékhely & $25 \%$ & $16 \%$ & $30 \%$ & ékszer & $3 \%$ & & $4 \%$ \\
\hline Egyéb város & $8 \%$ & $9 \%$ & $7 \%$ & kupon & $3 \%$ & $5 \%$ & $1 \%$ \\
\hline Falu & $2 \%$ & $2 \%$ & $2 \%$ & kozmetikum & $2 \%$ & & $4 \%$ \\
\hline Milyen gyakran szoktál interneten vásárolni? & $N=144 f^{\prime \prime}$ & $N=54 f_{o}^{\prime \prime}$ & $N=92 f^{\prime \prime}$ & mobiletelefon kiegészítőt & $2 \%$ & & $3 \%$ \\
\hline Általában heti rendszerességgel & $6 \%$ & $2 \%$ & $8 \%$ & PC játék, videójáték & $2 \%$ & $5 \%$ & \\
\hline Általában havi rendszerességgel & $30 \%$ & $41 \%$ & $23 \%$ & szállás, üdülés & $1 \%$ & $4 \%$ & \\
\hline Általában kéthavonta & $19 \%$ & $22 \%$ & $18 \%$ & egyéb & $7 \%$ & $2 \%$ & $10 \%$ \\
\hline Ritkábban mint kéthavonta & $45 \%$ & $35 \%$ & $51 \%$ & Terméket összesen & $62,5 \%$ & & $100 \%$ \\
\hline Általában mit szoktál vásárolni? több válasz & $N=144 f^{\prime \prime}$ & $N=56 f_{0}^{\prime \prime}$ & $N=92 f^{\prime \prime}$ & Szolgáltatást összesen & $37,5 \%$ & $100 \%$ & \\
\hline Könyv, újság, magazin & $17 \%$ & $15 \%$ & $19 \%$ & Legutolsó vásárlásodkor mennyit költöttél? & $N=147 f^{\prime \prime}$ & $N=56 f^{\prime \prime}$ & $N=91 f^{\prime \prime}$ \\
\hline Mozi-, színházjegy, egyéb belépők & $16 \%$ & $19 \%$ & $14 \%$ & $2000 \mathrm{Ft}$ alatt & $21 \%$ & $16 \%$ & $24 \%$ \\
\hline Utazás, repülöjegy & $15 \%$ & $21 \%$ & $12 \%$ & $2000-2999 \mathrm{Ft}$ & $13 \%$ & $3 \%$ & $19 \%$ \\
\hline Meleg étel rendelése & $13 \%$ & $11 \%$ & $14 \%$ & $3000-3999 \mathrm{Ft}$ & $12 \%$ & $11 \%$ & $12 \%$ \\
\hline Szállás & $10 \%$ & $11 \%$ & $10 \%$ & $4000-4999 \mathrm{Ft}$ & $12 \%$ & $7 \%$ & $14 \%$ \\
\hline Számítástechnika & $8 \%$ & $8 \%$ & $9 \%$ & $5000-7999 \mathrm{Ft}$ & $11 \%$ & $11 \%$ & $12 \%$ \\
\hline Ruházat, sporteszközök & $7 \%$ & $4 \%$ & $9 \%$ & $8000-11999 \mathrm{Ft}$ & $13 \%$ & $18 \%$ & $10 \%$ \\
\hline Szórakoztató technika, müszaki cikkek & $7 \%$ & $8 \%$ & $7 \%$ & $12000-19999 \mathrm{Ft}$ & $6 \%$ & $7 \%$ & $6 \%$ \\
\hline Élelmiszer & $2 \%$ & $1 \%$ & $2 \%$ & $20000 \mathrm{Ft}$ vagy a feletti összegért & $12 \%$ & $27 \%$ & $3 \%$ \\
\hline Háztartási gépek & $2 \%$ & $1 \%$ & $2 \%$ & Legutolsó vásárlásodkor mennyit költöttél? & $N=147 f_{o}^{\prime \prime}$ & $N=56 f^{\prime \prime}$ & $N=92 f^{\prime \prime}$ \\
\hline Egyéb & $2 \%$ & $1 \%$ & $2 \%$ & Banki átutalással & $22 \%$ & $27 \%$ & $16 \%$ \\
\hline \multirow{3}{*}{ (n) } & & & & Bankkártyával vagy hitelkártyával & $34 \%$ & $55 \%$ & $21 \%$ \\
\hline & & & & $\begin{array}{l}\text { A vásárolt termék/szolgáltatás átvételekor } \\
\text { készpénzben vagy utalvánnyal }\end{array}$ & $43 \%$ & $16 \%$ & $60 \%$ \\
\hline & & & & Egyéb & $3 \%$ & $2 \%$ & $3 \%$ \\
\hline
\end{tabular}

3. táblázat: A minta leíró jellemzői (2012-es kutatás)

Forrás: eredmények alapján saját szerkesztés 


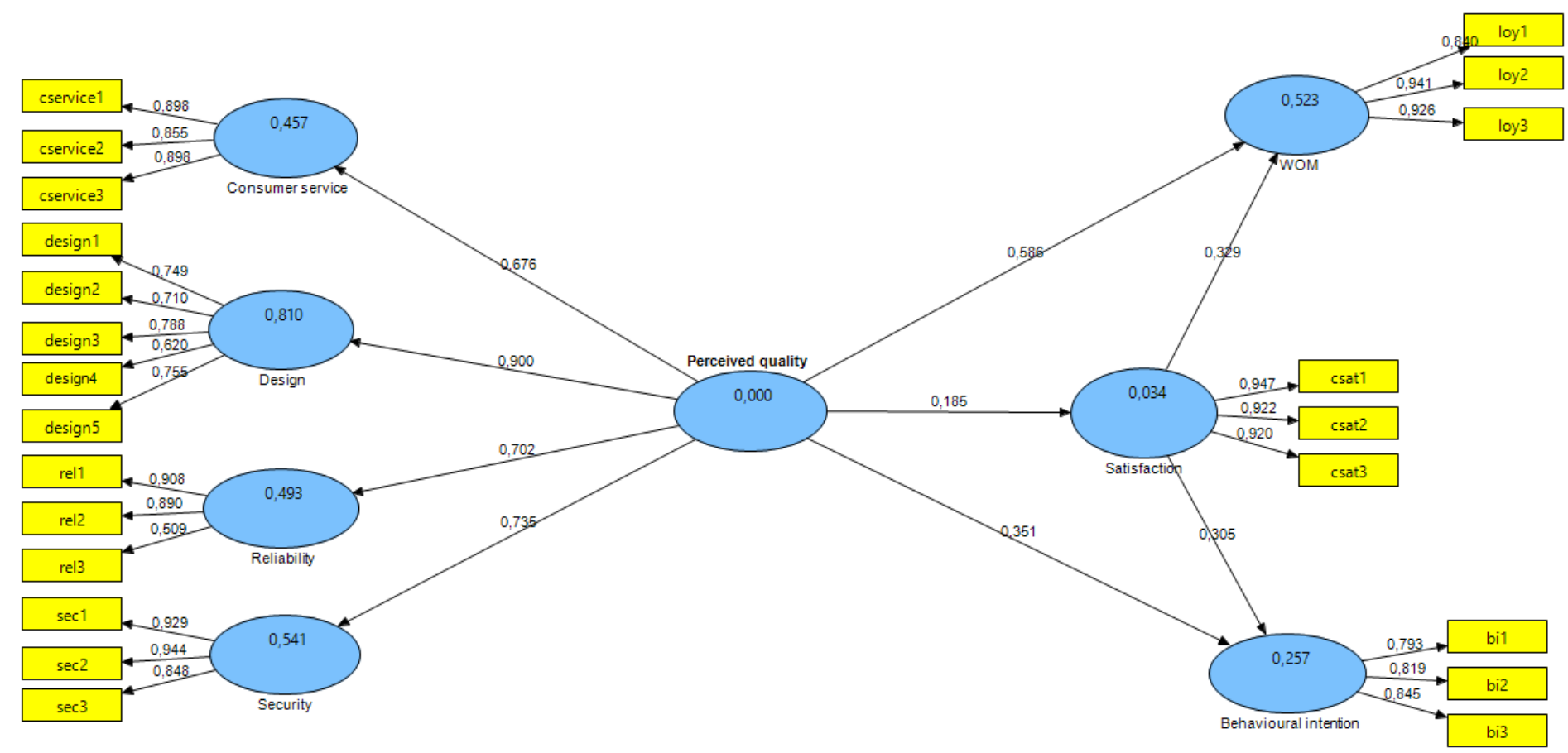

3.ábra: A PLS útelemzés eredményei szolgáltatások esetében

Forrás: eredmények alapján saját szerkesztés 


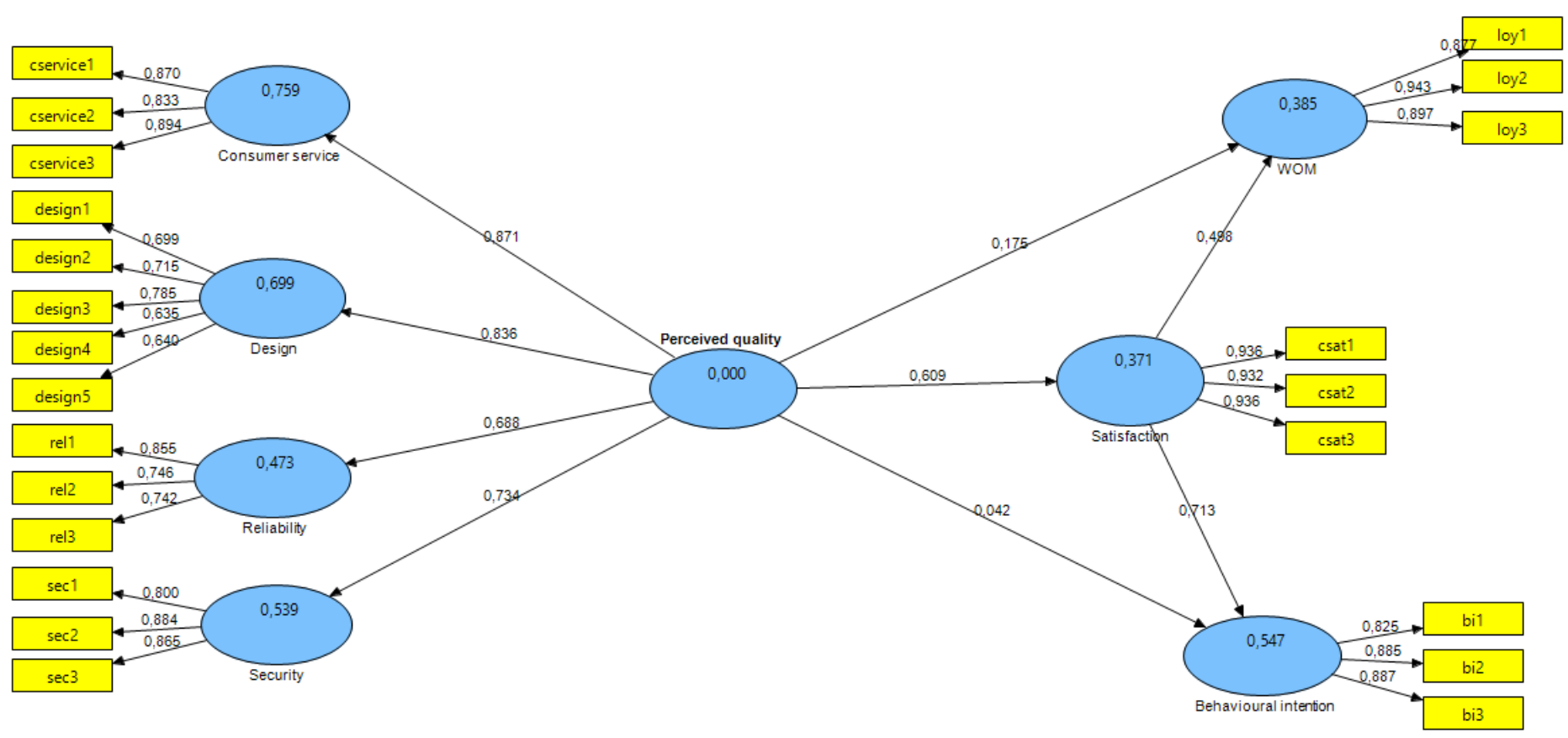

4.ábra: A PLS útelemzés eredményei termékek esetében

Forrás: eredmények alapján saját szerkesztés 


\section{A szerző témában megjelent publikációi}

\section{Magyar nyelvü tudományos könyv, könyvfejezet}

1. Nagy Ákos - Kemény Ildikó - Szücs Krisztián - Simon Judit (2014): Online szájreklám és elégedettség közti kapcsolat - Az 'első benyomás' szerepe az eWOM elfogadásban. In: Elméleti igényességgel - a gyakorlat igényei szerint... Szerk: Fojtik János. ISBN: 978-615-5457-26-5, 285 - 300. old.

\section{Magyar nyelvű referált szakmai folyóiratok}

1. Somogyi Ildikó (2013): Az online-fogyasztói elégedettségmérés hatása a vállalatok versenyképességére. Vezetéstudomány 2013/3, 49-60. old

\section{Egyéb folyóirat:}

1. Somogyi Ildikó (2014): Az online fogyasztói elégedettségmérés hatása a vállalatok versenyképességére 2. rész. Magyar Minőség (ISSN 1789-5510) 2014/6, 15-23. oldal

2. Somogyi Ildikó (2014): Az online fogyasztói elégedettségmérés hatása a vállalatok versenyképességére 1. rész. Magyar Minőség (ISSN 1789-5510) 2014/5, 29-36. oldal

\section{Magyar nyelvű konferencia részvétel teljes tanulmány megjelenéssel}

3. Kemény Ildikó - dr. Simon Judit - Ugray Zsolt (2014): Te továbbajánlanád? Az offline és online továbbajánlási szándék alakulása az e-kiskereskedelemben. A Magyar Marketing Szövetség Marketing Oktatók Klubja 20. országos konferenciája, 2014. augusztus 27-29., Szeged. ISBN: 9789633063125, 1-8. old

4. Nagy Ákos - Kemény Ildikó - Szűcs Krisztián - Simon Judit (2014): Az online vásárlást befolyásoló tényezők vizsgálata, különös tekintettel az elektronikus szájreklám hatására. A Magyar Marketing Szövetség Marketing Oktatók Klubja 20. országos konferenciája, 2014. augusztus 27-29., Szeged. ISBN: 9789633063125, 1-8. old

5. Kemény Ildikó - Ugray Zsolt - Simon Judit (2013): Elégedettség és újravásárlási szándék alakulása az e-kereskedelemben a szolgáltatásokkal, illetve a termékeket vásárlók körében. Marketing Oktatók Klubja, 19. Országos Konferencia, 2013. augusztus, Budapest. ISBN:978-963-661-995-4, 1-8. old.

6. Somogyi Ildikó - dr. Simon Judit (2012): Online szolgáltatásminőség-mérés egy hazai online gyógyszertár esetében. Marketing Oktatók Klubja, 18. Országos Konferencia, 2012, 2012. augusztus, Miskolc. ISBN:978-963-661-995-4, 1-9. old

7. Somogyi Ildikó (2011): Az online fogyasztói elégedettségmérés lehetőségei szakirodalmi áttekintés. Marketing Oktatók Klubja, 18. Országos Konferencia, 2011, 2011. augusztus, Pécs. ISBN 978-963-642-391-9 2, 417-428. old.

\section{Magyar nyelvü mühelytanulmány}

1. Somogyi Ildikó (2012): Az online-fogyasztói elégedettség mérésére alkalmas skála tesztelése és véglegesítése a vállalati döntéshozók támogatása céljából. Mühelytanulmány in Versenyképesség kutatás mühelytanulmány-sorozat. BCE Versenyképesség Kutató Központ. Vállalatgazdaságtan Intézet, Budapest. ISNN 1787-6915 Elérhetö: http://unipub.lib.uni-corvinus.hu/865/1/TM23_Somogyi.pdf 
Idegen nyelvü konferencia részvétel és teljes tanulmány megjelenés

1. Kemény Ildikó - Ugray Zsolt - Simon Judit (2013): Online-consumer satisfaction and word of mouth in case of services buyers and products buyers. EMAC Regional Conference, 2013. szeptember 25-27., Szentpétervár. ISBN 978-5-9924-0081-6. 152 - 160 old. Elérhetö:

http://www.gsom.spbu.ru/files//4th_emac_cee_conference_2013_proceedings.pd $f$, old

2. Somogyi Ildikó (2012): How to measure electronic service quality? A hungarian example. DOKBAT Konferencia, 2012. április, Zlín, Csehország., 1-8. old

3. Nagy, Á. - Kemény, I. - Szücs, K - Simon, J. (2014): The relationship between online opinion seeking and customer satisfaction with online stores in hungary. M-Sphere Conference, Zadar, 2014. okt 2-4. Book of Papers: 978-953-7930-066. 166-177. old. Elérhetö: http://www.m-sphere.com.hr/book-of-papers-2014 